\title{
Arbeidsmarktmonitor Metalektro 2005
}

Citation for published version (APA):

van Loo, J. B., de Grip, A., \& Lintjens, E. L. M. (2006). Arbeidsmarktmonitor Metalektro 2005. ROA. ROA Reports No. 5 https://doi.org/10.26481/umarep.2006005

Document status and date:

Published: 01/01/2006

DOI:

10.26481/umarep.2006005

Document Version:

Publisher's PDF, also known as Version of record

\section{Please check the document version of this publication:}

- A submitted manuscript is the version of the article upon submission and before peer-review. There can be important differences between the submitted version and the official published version of record.

People interested in the research are advised to contact the author for the final version of the publication, or visit the DOI to the publisher's website.

- The final author version and the galley proof are versions of the publication after peer review.

- The final published version features the final layout of the paper including the volume, issue and page numbers.

Link to publication

\footnotetext{
General rights rights.

- You may freely distribute the URL identifying the publication in the public portal. please follow below link for the End User Agreement:

www.umlib.nl/taverne-license

Take down policy

If you believe that this document breaches copyright please contact us at:

repository@maastrichtuniversity.nl

providing details and we will investigate your claim.
}

Copyright and moral rights for the publications made accessible in the public portal are retained by the authors and/or other copyright owners and it is a condition of accessing publications that users recognise and abide by the legal requirements associated with these

- Users may download and print one copy of any publication from the public portal for the purpose of private study or research.

- You may not further distribute the material or use it for any profit-making activity or commercial gain

If the publication is distributed under the terms of Article $25 \mathrm{fa}$ of the Dutch Copyright Act, indicated by the "Taverne" license above, 


\section{Arbeidsmarktmonitor Metalektro 2005}

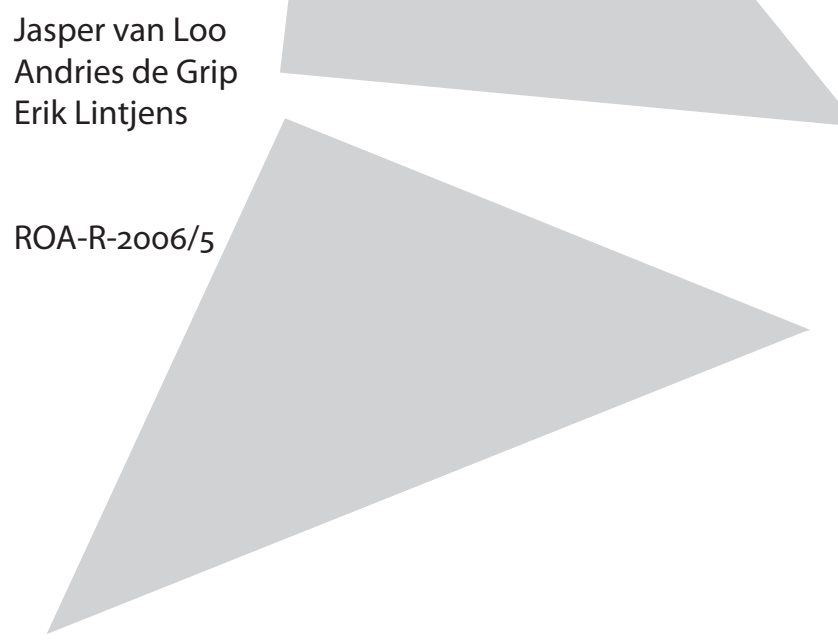




\section{Colofon}

(C) Researchcentrum voor Onderwijs en Arbeidsmarkt (ROA). Niets uit deze uitgave mag op enige manier worden verveelvoudigd zonder voorafgaande schriftelijke toestemming van de directeur van het ROA.

\section{Researchcentrum voor Onderwijs en Arbeidsmarkt}

Faculteit der Economische Wetenschappen en Bedrijfskunde

Universiteit Maastricht

\section{Vormgeving}

ROA secretariaat, Maastricht

\section{Verkoop}

Researchcentrum voor Onderwijs en Arbeidsmarkt

email: secretary@roa.unimaas.nl

website: www.roa.unimaas.nl

ISBN-IO: 90-532I-434-8

ISBN-I3: 978-90-532I-434-8

juni 2006 


\section{Inhoud}

Voorwoord

Management summary vii

1 Innovatie en marktontwikkelingen in de Metalektro 1

1.1 Conjuncturele ontwikkelingen 2

1.2 Innovaties 3

$\begin{array}{ll}1.3 \text { Internationalisering } & 10\end{array}$

1.4 De Nederlandse Metalektro in Europees perspectief 12

2 Arbeidsmarktontwikkelingen $\quad 17$

2.1 De werkgelegenheidsontwikkelingen van de afgelopen jaren $\quad 18$

2.2 Instroom, uitstroom en werkgelegenheid in de periode 2002-2005 19

2.3 Instroom van nieuwe werknemers in $2005 \quad 20$

$\begin{array}{lll}2.4 \text { Personeelsuitstroom in } 2005 & 21\end{array}$

2.5 Krimpende werkgelegenheid in $2005 \quad 22$

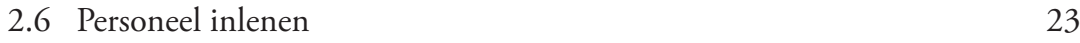

3 De werving van nieuw personeel $\quad 25$

$\begin{array}{lll}3.1 & \text { Verloop van personeel } & 27\end{array}$

$\begin{array}{lll}3.2 \text { Vacatures } & 28\end{array}$

$\begin{array}{ll}\text { 3.3 Problemen bij de werving van personeel } & 31\end{array}$

3.4 Wervingskanalen, gewenste competenties en het imago van het bedrijf 38

3.5 Werven in het buitenland $\quad 42$

4 Instroom van schoolverlaters $\quad 45$

4.1 Welke schoolverlaters stromen in? 46

4.2 Marktaandeel en concurrentiepositie 49

4.3 Aansluiting tussen opleiding en baan 53

4.4 Ontbrekende competenties van schoolverlaters en de rol van
het onderwijs

5 Scholing, inzetbaarheid en de loopbaan 59

5.1 Scholingsdeelname in de Metalektro $\quad 61$

$\begin{array}{ll}5.2 \text { Soorten cursussen en trainingen } & 62\end{array}$ 
5.3 Investeren in opleiden

5.4 Opleidingsdoelen en belemmeringen $\quad 68$

$\begin{array}{ll}5.5 \text { Brede inzetbaarheid } & 70\end{array}$

$\begin{array}{ll}\text { 5.6 Loopbanen in de Metalektro } & 74\end{array}$

6 HRM-beleid in de Metalektro $\quad 77$

$\begin{array}{ll}\text { 6.1 Ontwikkelingen in de afgelopen jaren } & 79\end{array}$

6.2 Waarop is het HRM gericht? $\quad 82$

6.3 Doelgroepen in het HRM-beleid 84

7 De Metalektro in de toekomst

7.1 Verwachte arbeidsmarktontwikkelingen 90

$\begin{array}{ll}7.2 \text { Vergrijzing } & 96\end{array}$

$\begin{array}{ll}7.3 \text { Speerpunten voor toekomstig personeelsbeleid } & 101\end{array}$

$\begin{array}{ll}7.4 \text { Opleiden in de toekomst } & 103\end{array}$

$\begin{array}{lll}8 & \text { Agenda voor de toekomst } & 107\end{array}$

$\begin{array}{ll}\text { 8.1 De Agenda voor de Toekomst } & 108\end{array}$

8.2 Is de Metalektro op de goede weg? $\quad 108$

$\begin{array}{ll}8.3 \text { Nieuwe prioriteiten } & 112\end{array}$ 


\section{Voorwoord}

Begin 2002 is in opdracht van de Stichting A+O de Arbeidsmarktmonitor Metalektro opgezet. Deze monitor geeft inzicht in de actuele en toekomstige ontwikkelingen op personeels- en arbeidsmarktgebied in de metalektrosector. Dit rapport vormt de afsluiting van de vierde jaarcyclus van de arbeidsmarktmonitor. Het presenteert de belangrijkste resultaten van het speciaal voor de monitor opgezette Werkgeverspanel Metalektro. De uitkomsten van dit werkgeverspanel worden aangevuld met informatie over de metaal en elektrotechnische sector uit diverse andere bronnen. Daarnaast zijn er interviews gehouden met aan het Werkgeverspanel deelnemende metalektrobedrijven, om dieper te kunnen ingaan op de achtergronden van bepaalde ontwikkelingen. De meest opmerkelijke uitspraken uit deze interviews krijgen een prominente plaats aan het begin van ieder hoofdstuk van deze rapportage.

In 2005 hebben er twee metingen van het Werkgeverspanel Metalektro plaatsgevonden.. In iedere meting beantwoordt een representatieve groep bedrijven uit de Metalektro online een lijst met vragen over de in- en uitstroom van personeel en het aantal openstaande vacatures. Naast deze standaardvragen wordt er in iedere meting ingegaan op bepaalde thema's zoals werving en selectie, de inzetbaarheid en de doorstroom van personeel, en de competenties en scholing van het technisch personeel. Evenals in voorgaande jaren is er in 2005 weer veel aandacht geweest voor het verder verbeteren van de vraagstellingen in de enquêtes. De feedback van de deelnemende bedrijven is gebruikt om bepaalde vragen verder aan te scherpen en nog beter af te stemmen op de behoefte van de bedrijven.

Bij de start van het panel in 2002 zijn alle Metalektrobedrijven, die aangesloten zijn bij de werkgeversorganisatie FME-CWM en vallen onder de CAO Metalektro benaderd om deel te nemen aan het panel. Van de ruim I.20o bedrijven reageerden er 345 positief. In de afgelopen jaren heeft een aantal bedrijven zich afgemeld, maar er is ook een aantal nieuwe bedrijven bijgekomen. Om het panel op peil te houden en mogelijk te laten groeien zijn alle potentiële deelnemers onlangs opnieuw benaderd met het verzoek om mee te doen aan het panel. De positieve respons op deze wervingactie geeft goede hoop voor een verhoging van de respons in de nabije toekomst. Deze hogere respons zal mogelijkheden bieden om de uitkomsten van de monitor verder te kunnen verbijzonderen naar sector en regio. 
Om een representatief beeld te kunnen geven van de ontwikkelingen in de Nederlandse Metalektro worden de gegevens van de deelnemende bedrijven gewogen naar bedrijfsomvang, bedrijfssector en regio. Om vervolgens uitspraken te kunnen doen over bijvoorbeeld het totale aantal vacatures dat in de Metalektro openstaat, is het aantal vacatures dat bij de deelnemende bedrijven openstaat opgehoogd. Deze ophoging van vacaturecijfers komt overeen met de procedure die het CBS volgt in hun vacature-enquête. Deze aanpak heeft als voordeel dat we een goed beeld kunnen geven van de ontwikkeling van het totale aantal vacatures dat er bij de bedrijven in de Metalektro openstaat. Ook de cijfers over de in- en uitstroom van werknemers in de Metalektro zijn opgehoogd tot in de tijd vergelijkbare totaalcijfers voor de hele sector.

Bij iedere meting van het Werkgeverspanel Metalektro worden de uitkomsten gepubliceerd in een door de Stichting $\mathrm{A}+\mathrm{O}$ uitgegeven nieuwsbrief. In deze nieuwsbrief wordt niet alleen gerapporteerd over de actuele arbeidsmarktsituatie (vacatures, instroom en uitstroom) en de korte-termijn arbeidsmarktverwachtingen die bedrijven hebben, maar komen ook andere trends en ontwikkelingen, zoals bijvoorbeeld de scholingsdeelname van het personeel en de toekomstige ontwikkelingen in het HRM-beleid aan de orde. Daarnaast bevat iedere nieuwsbrief een redactioneel commentaar waarin de dynamiek in de Metalektro en de situatie op de arbeidsmarkt in een wat breder perspectief gezet worden. Op deze wijze wordt geprobeerd meer inzicht te geven in wat de gevolgen van bepaalde ontwikkelingen zijn en wat dat voor het beleid kan betekenen. Ieder deelnemend bedrijf ontvangt ook nog een "bedrijfsfoto". Dit benchmarkinstrument vergelijkt de positie van het eigen bedrijf met het algemene beeld van de bedrijfstak.

De Arbeidsmarktmonitor heeft sinds enige tijd ook een eigen plaats op het Internet. Op de website www.arbeidsmarktmonitormetalektro. $n l$ kunnen bedrijven (en andere geïnteresseerden) meer achtergrondinformatie over de arbeidsmarktmonitor vinden, of zich aanmelden als deelnemer van de monitor. Ook de nieuwsbrieven en deze jaarrapportage kunnen via deze website gedownload worden.

De uitvoering van de Arbeidsmarktmonitor Metalektro en het samenstellen van deze jaarrapportage staat onder leiding van een regiecommissie. De auteurs van dit rapport willen de leden van deze regiecommissie hartelijk bedanken voor hun constructieve begeleiding van het onderzoek: Henry de Groot (Stichting A+O), Rien Smit (FME-CWM), Patricia Faber en Hilde ter Doest (FNV Bondgenoten), Ivo Kuijpers en Quirien van Ojen (Orbis Advies en Onderzoek) en Maarten Brouwer (CentERdata). Het veldwerk voor het Werkgeverspanel Metalektro is uitgevoerd door Maarten Brouwer en Marika Puumela van CentERdata. Sander Dijksman (ROA) werkte mee aan de statistische analyses in dit rapport. Een laatste woord van dank gaat naar de bedrijven die suggesties voor verbeteringen in de enquêtes hadden en de bedrijven die bereid waren om deel te nemen aan de interviews. Juist de input van de deelnemende bedrijven blijft cruciaal bij het verbeteren en verder ontwikkelen van de Arbeidsmarktmonitor Metalektro. 


\section{Management summary}

Innovatie en marktontwikkelingen

De recessie waarmee de metalektrosector de afgelopen jaren te maken had, lijkt voorbij. Voor 2006 wordt er weer voor alle sectoren binnen de Metalektro groei verwacht, vooral in de high-tech sectoren. Deze groei vertaalt zich echter niet in een stijgende werkgelegenheid, doordat de bedrijven aanzienlijke productiviteitsstijgingen realiseren. De conjuncturele ontwikkelingen in 2005 verschillen sterk tussen de sectoren binnen de Metalektro, wat betekent dat de eerder geconstateerde opleving van de conjunctuur zich niet overal in gelijke mate heeft doorgezet. Met name in de basismetaal, de instrumenten en optische industrie en de transportmiddelensector is de ontwikkeling van de afzet wat achtergebleven bij de optimistische groeiverwachtingen van enige tijd eerder.

De Metalektro heeft te maken met technologische innovaties in productieprocessen en veranderingen in de producten die er worden gemaakt. Maar liefst $94 \%$ van de bedrijven verwacht dat er de komende vijf jaar in hun bedrijf nieuwe technologische innovaties zullen plaatsvinden, die vaak betrekking hebben op productinnovaties $(80 \%)$, procesinnovaties $(49 \%)$ en verregaande automatisering van de productieprocessen $(42 \%)$. Niet alleen de technologische vooruitgang, maar ook het realiseren van kostenbesparingen is een belangrijke reden voor de dynamiek van het productieproces. Technologische innovaties staan ook zelden los van organisatorische veranderingen. Maar liefst 92\% van de bedrijven verwacht de komende vijf jaar dat de organisatie van hun productieprocessen zal veranderen. De belangrijkste ontwikkeling is dat er een steeds grotere flexibele inzet van het personeel verwacht wordt. Ook verwachten veel bedrijven dat ze bepaalde activiteiten gaan uitbesteden aan buitenlandse bedrijven ('off-shoring'). Organisatorische veranderingen hebben overigens lang niet altijd een negatieve invloed op de omvang van het personeelsbestand: $37 \%$ van de bedrijven verwacht de komende tijd juist een uitbreiding van het personeelsbestand. Ook gaat ruim eenderde van de bedrijven niet met minder personeel werken, maar willen ze het personeel wel op een ander manier gaan inzetten, bijvoorbeeld door teamgerichter te gaan werken.

De technologische innovaties en organisatorische veranderingen hebben ook gevolgen voor de functies van het technisch personeel. Maar liefst $92 \%$ van de bedrijven verwacht dat hierdoor de inhoud van de technische functies in hun bedrijf zal veranderen. De 
belangrijkste veranderingen zijn het belangrijker worden van gedragsmatige competenties en de grotere nadruk op klantgerichtheid, maar er is geen duidelijke trend naar bredere of juist smallere technische functies: De innovatiedynamiek leidt er in $55 \%$ van de bedrijven toe dat de technische functies meer all-round zullen worden, terwijl $32 \%$ van de bedrijven juist verwacht dat er meer specialisatie zal optreden. Er is wel sprake van een duidelijke verschuiving van de verantwoordelijkheden naar de werkvloer: $53 \%$ van de bedrijven verwacht dat de verantwoordelijkheden in de technische functies op een lager niveau zullen toenemen. Dit duidt erop dat de metalektrobedrijven zich steeds meer zullen ontwikkelen tot zogenaamde 'high performance workplaces'.

Naast de dynamiek speelt ook de internationalisering in de Metalektro een grote rol. Bedrijven in de metaal en elektrotechnische sector exporteren momenteel ruim de helft van hun afzet. Dit exportaandeel neemt de laatste jaren toe. Ook de bedrijfsactiviteiten worden steeds meer geïnternationaliseerd. Nogal wat bedrijven verwachten dat ze de komende jaren delen van hun productie aan buitenlandse (44\%) of binnenlandse bedrijven zullen gaan uitbesteden. De grote dynamiek in de Nederlandse Metalektro roept de vraag op hoe de sector zich verhoudt tot de metalektrosectoren in de ons omringende landen. Gezien de hoge arbeidsproductiviteit presteert de basismetaal en de sector metaalproducten in Nederland erg goed in vergelijking met andere landen. Daarentegen is België koploper in de machine-industrie, de elektrotechniek en de transportmiddelensector. Wat betreft de investeringen per werknemer loopt de Nederlandse metaal en elektrotechnische sector wat achter bij de ons omringende landen. Er zijn ook enkele duidelijke verschillen in de structuur van de werkgelegenheid. In de Nederlandse metaal en elektrotechnische sector werken relatief veel mannen en wordt er veel part-time gewerkt. De vergrijzing van het personeelsbestand is in Nederland echter minder groot dan in de ons omringende landen.

\section{Arbeidsmarktontwikkelingen}

Nieuwe productietechnieken en organisatorische innovaties in de metaal en elektrotechnische sector leiden tot productiviteitsstijgingen. Wanneer de afzet onvoldoende toeneemt om deze productiviteitsstijging op te vangen, zal er sprake zijn van een krimpende werkgelegenheid. Deze krimp gaat gepaard met een veranderende werkgelegenheidsstructuur: Upgrading van functie-eisen leidt ertoe dat het werkgelegenheidsaandeel van laagopgeleide werknemers daalt, terwijl de vraag naar hoogopgeleiden toeneemt. Uit het werkgeverspanel Metalektro blijkt dat in de jaren 2002-2005 het niveau van de instroom onder het niveau van de uitstroom lag, wat betekent dat de werkgelegenheid steeds verder is afgenomen. Het niveau van zowel de in- als uitstroom nam in die periode ook af, mede als gevolg van de ongunstige conjuncturele ontwikkeling. Dit betekent dat ook de arbeidsmarktdynamiek kleiner is geworden.

Het grootste gedeelte van de instroom van nieuwe medewerkers in 2005 had betrekking op uitvoerende technische functies en technische en niet-technische ondersteunende functies. In de tweede helft van het jaar steeg de instroom van technici en niet- 
technisch leidinggevenden, terwijl de instroom van technisch opgeleide verkopers juist daalde. De personeelsuitstroom in 2005 had vooral betrekking op uitvoerende technici. In de loop van het jaar is de uitstroom van personeel echter in bijna alle functiecategorieën gestegen, vanwege de verbeterende conjuncturele situatie, waardoor meer mensen het weer aandurven om op zoek te gaan naar een andere baan, en door de vergrijzing van het personeelsbestand, waardoor meer werknemers als gevolg van pensionering de Metalektro verlaten. Ondanks de wat verbeterde conjuncturele situatie is er echter in nog ruim een kwart van de bedrijven sprake van een krimpende werkgelegenheid voor uitvoerende technici, terwijl de werkgelegenheid voor ondersteunend niet-technisch personeel in $20 \%$ van de bedrijven krimpt. De krimp voor technisch opgeleide verkopers is in de loop van 2005 afgenomen, wat volgens de bedrijven het gevolg is van het toenemende belang van een goed verkoopapparaat.

De metalektrobedrijven kunnen ook voorzien in hun personeelsbehoefte door gebruik te maken van personeel dat in dienst is van een bedrijf dat niet tot de metalektrosector behoort. Het gaat dan om uitzendkrachten, ingeleend personeel of gedetacheerde werknemers. In 2005 werden er ruim I0.000 uitvoerende technici ingeleend. Daarnaast werd er heel wat ondersteunend personeel op flexibele basis ingezet. Het totaal aantal mensen dat is ingeleend is gestegen van 16.500 in de eerste helft van 2005 tot bijna I8.000 in de laatste helft van het jaar. Deze toename had vooral betrekking op ondersteunende technici. Overigens blijkt dat het inlenen van personeel niet alleen plaatsvindt om pieken in de bedrijfsdrukte op te vangen. Veel bedrijven lenen ook personeel in het kader van de werving van personeel: de beste uitzendkrachten komen dan uiteindelijk in dienst van de bedrijven zelf.

\section{De werving van nieuw personeel}

De ontwikkelingen in de Metalektro vereisen dat de bedrijven over voldoende personeel met de juiste kwalificaties beschikken. Het is in dat kader van belang dat het verloop van personeel niet te groot, maar ook niet te klein is. Het is goed als bedrijven door het vervangen van personeel de beschikking krijgen over nieuwe kennis en vaardigheden, maar tegelijkertijd moet het verloop ook weer niet te groot zijn, omdat dan de in het bedrijf opgebouwde kennis en vaardigheden te snel verloren kunnen gaan. De meeste bedrijven vinden overigens dat er erg weinig verloop plaatsvindt en verwachten op dit punt geen grote verandering in de komende jaren. Wel is het aantal bedrijven dat een toename van het verloop verwacht groter dan het aantal bedrijven dat een afnemend verloop verwacht. Dit wordt waarschijnlijk veroorzaakt door de verwachte toename van de uitstroom van personeel als gevolg van pensionering in de komende jaren.

De ontwikkeling van het totaal aantal vacatures in de Metalektro weerspiegelt de conjuncturele ontwikkelingen. In 2002 en 2003 was er sprake van een daling van het totale aantal vacatures. Gedurende 2004 was er eerst sprake van een stijging, maar daarna daalde het aantal vacatures weer. In de eerste helft van 2005 daalde het aantal 
vacatures verder, maar in de tweede helft van dat jaar was er weer sprake van een aanzienlijke stijging. Op dat moment stonden er weer bijna 4.000 vacatures bij de metalektrobedrijven open. In 2005 hadden de meeste vacatures betrekking op uitvoerende en ondersteunende technische functies. De stijging van het aantal vacatures in de tweede helft van 2005 was vooral geconcentreerd in de leidinggevende en ondersteunende technische functies. De meeste vacatures stonden in 2005 minder dan 3 maanden open.

In de jaren 2002-2004 kregen de bedrijven in de Metalektro door de neergaande conjunctuur steeds minder problemen bij het aantrekken van technisch personeel. In 2005 werd het werven van technisch personeel echter weer iets moeilijker: $20 \%$ van de bedrijven ondervond het afgelopen jaar weer veel problemen bij het vinden van technisch personeel, terwijl het aantal bedrijven met erg weinig of helemaal geen wervingsproblemen wat daalde. Veel bedrijven verwachten dat deze trend zich de komende jaren zal doorzetten, doordat er voor bepaalde soorten personeel weer een krapte op de arbeidsmarkt zal ontstaan. De problemen bij de recruterering van technisch personeel hebben vooral betrekking op een tekortschietend aanbod van sollicitanten met de juiste competenties of voldoende werkervaring. Een derde wervingsprobleem is een tekortschietend aanbod van schoolverlaters, maar dit probleem wordt, vanwege de toenemende waarde die bedrijven in de afgelopen jaren zijn gaan hechten aan werkervaring, wel voor steeds minder bedrijven relevant. Nog maar weinig bedrijven vinden dat de salariseisen van sollicitanten een probleem vormen bij het aantrekken van personeel, maar een aantal bedrijven verwacht wel dat dit probleem de komende jaren weer aan belang zal gaan winnen.

Veel metalektrobedrijven gaan innovatief te werk wanneer ze problemen bij het aantrekken van nieuw personeel ervaren. In 2005 ging ruim $70 \%$ van de bedrijven met wervingsproblemen het personeel flexibel inzetten. Flexibele inzet van het eigen personeel als reactie op wervingsproblemen is de laatste jaren flink in populariteit toegenomen. Een tweede maatregel bij problemen bij het recruteren van nieuwe werknemers is het laten overwerken van het personeel dat in dienst is. Hier ging maar liefst $64 \%$ van de bedrijven met wervingsproblemen toe over. Verder probeert $60 \%$ van de bedrijven de wervingsproblemen te verminderen door het eigen personeel om- of bij te scholen. Problemen bij het aantrekken van personeel kunnen er ook toe leiden dat bedrijven hun wervings- en selectiebeleid gaan aanpassen. Het is opvallend dat de laatste jaren steeds meer bedrijven uitzendbureaus of andere commerciële bureaus in zijn gaan zetten bij moeilijk vervulbare vacatures: in 2005 deed maar liefst $80 \%$ van de bedrijven met recruteringsproblemen dat. Het aantrekken van personeel met minder ervaring was in 2005 voor circa eenderde van de bedrijven een middel om wervingsproblemen te verlichten, maar dit was duidelijk minder vaak dan in 2004 .

De manier waarop bedrijven hun personeel recruteren hangt in grote mate samen met het soort personeel waarnaar ze op zoek zijn. Eenderde van de bedrijven vindt dat uitvoerende en ondersteunende technici het best geworven kunnen worden door 
gebruik te maken van de diensten van een uitzendbureau. Om leidinggevende technici en technisch opgeleide verkopers aan te trekken wordt vaak gebruik gemaakt van een commercieel wervingsbureau. Er zijn de laatste jaren ook een aantal belangrijke trends in de effectiviteit van de verschillende wervingskanalen. Steeds minder bedrijven vinden het adverteren in regionale kranten een effectief recruteringsinstrument. De rol van internet als wervingsinstrument is daarentegen de laatste jaren weer iets belangrijker geworden. Bij sommige bedrijven heeft het aantrekken van personeel via internet echt een grote vlucht genomen, niet alleen voor het hoger opgeleid personeel, maar in toenemende mate ook voor middelbaar opgeleide technici. Ook minder formele manieren van personeelswerving zijn voor een aantal bedrijven van belang. Het gaat dan vooral om werven via externe relaties of andere informele kanalen. De bedrijven in de Metalektro ondernemen overigens ook heel wat activiteiten om hun imago op de arbeidsmarkt te versterken. Maar liefst tweederde van de bedrijven probeert het imago te versterken door contacten met het voortgezet onderwijs, $42 \%$ van de bedrijven organiseert bedrijfsexcursies om het bedrijfsimago te versterken en $35 \%$ van de bedrijven is actief bezig om het werk dat binnen het bedrijf gedaan wordt te promoten.

Bij de werving van technisch personeel kijken de bedrijven in de Metalektro vooral naar het niveau van de vaktechnische vaardigheden. Daarnaast selecteert meer dan de helft van de bedrijven hun personeel op basis van competenties als het beschikken over probleemoplossend vermogen, het kunnen werken in teamverband en flexibiliteit. $39 \%$ van de bedrijven vindt het goed zelfstandig kunnen werken een belangrijke competentie bij het werven van nieuw personeel. Andere belangrijke competenties bij de werving van personeel zijn communicatieve vaardigheden en procesgericht kunnen werken.

Werven in het buitenland bij krapte op de Nederlandse arbeidsmarkt is maar voor weinig bedrijven van belang. Slechts circa I\% van het totale personeelsbestand in de Metalektro is afkomstig uit het buitenland. Deze groep bestaat vooral uit middelbaar opgeleide werknemers afkomstig uit andere EU landen. Bijna de helft van de bedrijven denkt niet dat werven van personeel in het buitenland in de komende jaren belangrijker zal worden. $22 \%$ verwacht echter wel dat ze de komende jaren meer personeel uit het buitenland zullen gaan aantrekken. In de praktijk blijkt het hierbij vooral te gaan om grotere bedrijven die veel hoogopgeleid willen aantrekken en die mensen onvoldoende op de Nederlandse arbeidsmarkt kunnen vinden. Een andere reden om personeel uit het buitenland aan te trekken is de betere arbeidsmentaliteit van personeel uit het buitenland. 


\section{Instroom van schoolverlaters}

Een gedeelte van de behoefte aan nieuw personeel wordt ingevuld door schoolverlaters in dienst te nemen. In 2004 namen de bedrijven in de metaal en elektrotechnische sector samen circa 4.000 schoolverlaters aan. Dat is heel wat minder dan in de voorgaande jaren. Dit kan verschillende redenen hebben. Enerzijds hechten bedrijven steeds meer waarde aan personeel met werkervaring. Anderzijds zijn bedrijven in het algemeen minder nieuwe werknemers gaan werven, doordat ze geconfronteerd zijn met een krimpende werkgelegenheid. Meer dan 40\% van de schoolverlaters die in de metaal en elektrotechnische sector zijn gaan werken hebben een opleiding gevolgd op $\mathrm{MBO}$ niveau. $23 \%$ van de schoolverlaters die instroomt zijn lager opgeleide VMBO'ers. Bij de helft van deze laagopgeleide instromers gaat het echter om mensen die een BBL-opleiding volgen, wat betekent dat deze mensen voor een aanzienlijk deel door de bedrijven zelf tot middelbaar niveau worden opgeleid. Het $\mathrm{HBO}$ is ook een grote leverancier van nieuwe arbeidskrachten geworden: bij maar liefst een kwart van de aangetrokken schoolverlaters ging het om een HBO'er. Ten slotte had $9 \%$ van de aangetrokken schoolverlaters een universitair diploma op zak. In de afgelopen jaren heeft er zich een opmerkelijke ontwikkeling in de instroom van schoolverlaters in de Metalektro voorgedaan: het percentage vrouwen onder de schoolverlaters die in de metaal en elektrotechnische sector aan de slag gaan is gehalveerd: van $18 \%$ in 2000 tot $9 \%$ in 2004 . Gezien de verwachte knelpunten in de toekomstige personeelsvoorziening is dit een zorgelijke ontwikkeling.

Het marktaandeel van de metaal en elektrotechnische sector in de totale arbeidsmarkt voor schoolverlaters is met $3,4 \%$ betrekkelijk klein. Tussen de verschillende sectoren binnen de metaal en elektrotechnische industrie zijn er wel aanzienlijke verschillen. Zo is het aantal schoolverlaters dat terecht komt in de machine-industrie veel groter dan het aantal schoolverlaters dat aan de slag gaat in de sector basismetaal. Dat het aandeel van schoolverlaters in de metaal en elektrotechnische sector klein is, betekent dat de sector moet concurreren met andere bedrijfssectoren om schoolverlaters aan te trekken. Drie opleidingen zijn voor de metaal en elektrotechnische industrie het belangrijkste: $\mathrm{MBO}$ werktuigbouwkunde en mechanische techniek, VMBO metaal en $\mathrm{HBO}$ werktuigbouwkunde. Deze drie opleidingen vertegenwoordigen circa $40 \%$ van de totale instroom van schoolverlaters in de metaal en elektrotechnische sector. $\mathrm{Bij} \mathrm{MBO}$ werktuigbouwkunde en mechanische techniek komt circa de helft van de schoolverlaters in de sector terecht. Op dit marktsegment is er vooral concurrentie met de bouwsector en de zakelijke dienstverlening. Van de schoolverlaters met een opleiding VMBO metaal komt ongeveer eenderde terecht in de metaal en elektrotechnische sector, terwijl $21 \%$ van de schoolverlaters met een opleiding VMBO metaal aan de slag gaat in de bouwsector. Daarnaast is er concurrentie met de sector handel en reparatie, de transport en communicatiesector en de zakelijke dienstverlening. De concurrentiepositie bij de werving van HBO'ers met een opleiding werktuigbouwkunde is relatief goed: de metaal en elektrotechnische sector weet circa $40 \%$ van het totaal aantal schoolverlaters met een $\mathrm{HBO}$ opleiding werktuigbouwkunde aan te 
trekken. Ook op dit arbeidsmarktsegment concurreert de metaal en elektrotechnische sector vooral met de zakelijke dienstverlening en de bouwsector.

Bedrijven zijn niet altijd tevreden over het niveau van de competenties van de schoolverlaters die ze in dienst nemen. Bijna $70 \%$ van de bedrijven vindt dat scholen in de toekomst nog meer aandacht moeten gaan besteden aan de ontwikkeling van vaktechnische vaardigheden. Ook vindt een ruime meerderheid van de bedrijven dat het onderwijs de komende jaren meer aandacht moet gaan besteden aan het ontwikkelen van het probleemoplossend vermogen. Andere competenties waar de scholen in de toekomst volgens heel wat bedrijven meer oog voor moeten hebben zijn flexibiliteit, communicatieve vaardigheden, zelfstandigheid en initiatief.

\section{Scholing, inzetbaarheid en de loopbaan}

Het opleiden van het technisch personeel blijft voor veel bedrijven in de Metalektro een belangrijke prioriteit: in 2005 werd in $77 \%$ van de bedrijven het personeel intern opgeleid, terwijl $86 \%$ van de bedrijven het personeel externe cursussen of trainingen aanbiedt. De ontwikkeling in de jaren 2002-2004, waarin er steeds meer intern wordt opgeleid, heeft zich in 2005 echter niet doorgezet: De bedrijven gingen in 2005 juist weer meer extern opleiden.

In bijna alle metalektrobedrijven volgt het personeel interne of externe cursussen op vaktechnisch gebied. Daarnaast volgt het personeel in nogal wat bedrijven cursussen of trainingen gericht op het stimuleren van veilig gedrag. In $42 \%$ van de bedrijven gebeurt dat intern, terwijl $26 \%$ van de bedrijven hun technisch personeel externe cursussen of trainingen veilig gedrag aanbiedt. Een derde belangrijk terrein waarop bedrijven hun personeel verder scholen heeft betrekking op IT cursussen of trainingen. In $36 \%$ van de bedrijven gebeurt dat extern, in $28 \%$ van de bedrijven intern. Enkele andere cursussen die in relatief veel bedrijven gevolgd worden zijn trainingen voor leidinggeven, cursussen procesgericht werken en communicatietrainingen. Daarnaast bieden nogal wat bedrijven hun personeel cursussen aan die gericht zijn op het verbeteren van het probleemoplossend vermogen.

De in 2004 gelanceerde POFI agenda heeft nog opmerkelijk weinig invloed op de formele scholingsparticipatie van het personeel. De deelname aan cursussen gericht op het omgaan met veranderingen, flexibiliteit en initiatief is in 2005 niet groter dan in 2004. De deelname aan cursussen gericht op het versterken van het probleemoplossend vermogen is daarentegen wel wat toegenomen. Overigens blijkt dat bedrijven naast formele cursussen en trainingen ook veel waarde hechten aan informeel leren. Daarbij is er ook vaak een wisselwerking tussen formeel en informeel leren, waarbij formeel leren informeel leren kan versterken.

In 2005 vonden de cursussen in $55 \%$ van de bedrijven in de tijd van het bedrijf plaats. In $26 \%$ van de bedrijven volgt het personeel cursussen in eigen tijd, terwijl er in $19 \%$ van 
de bedrijven sprake is van een gedeelde tijdsinvestering. Het aantal bedrijven waarbij er sprake is van een gedeelde tijdsinvestering is de laatste jaren gedaald, terwijl het aantal bedrijven waarin het personeel de cursussen geheel in eigen tijd volgt aanzienlijk is gestegen. De kosten voor cursussen en trainingen worden grotendeels (91\%) gedragen door de bedrijven zelf. De resterende $9 \%$ wordt gedragen door de werknemers zelf of door subsidies. De 'out-of-pocket' kosten voor trainingen en cursussen bedragen in 2005 circa $€ 45.000$ per bedrijf. Dit is gemiddeld $3 \%$ van de totale loonsom. Dit betekent dat de totale opleidingsinvesteringen in vergelijking met 2004 op peil gebleven zijn. De gemiddelde opleidingsinvesteringen per getrainde werknemer zijn in 2005 echter verder gedaald. Dit wijst op een verbreding van het opleidingsbeleid, waarbij de totale uitgaven over steeds meer werknemers gespreid worden.

Met het opleiden van het personeel heeft $80 \%$ van de metalektrobedrijven vooral het verbeteren van de vaardigheden die nodig zijn in iemands huidige functie voor ogen. $67 \%$ van de bedrijven ziet het aanleren van nieuwe vaardigheden voor de huidige functie als een belangrijk opleidingsdoel. Maar veel bedrijven hebben ook een lange termijn visie bij het investeren in hun technisch personeel: 50\% schoolt het personeel om de inzetbaarheid te vergroten, terwijl $40 \%$ het personeel nieuwe competenties laat verwerven die belangrijk zijn voor hun verdere loopbaan. De grote betrokkenheid van de metalektrobedrijven bij het opleiden van hun personeel, betekent echter niet dat ze de opleidingsdoelen die ze zichzelf stellen altijd kunnen realiseren. Meer dan de helft van de bedrijven ervaart bepaalde belemmeringen bij het opleidingsbeleid. Ruim $20 \%$ van de bedrijven vindt dat cursussen en trainingen te veel tijd of geld kosten. In $18 \%$ van de bedrijven is er sprake van problemen bij het vervangen van personeel dat een opleiding volgt. Voor een aantal bedrijven is het moeilijk om de gestelde opleidingsdoelen te realiseren doordat werknemers onvoldoende geïnteresseerd zijn of omdat het aanbod van cursussen tekortschiet. Er zijn de laatste jaren overigens wel enkele opmerkelijke ontwikkelingen in de mate waarin bedrijven bepaalde factoren als belemmerend ervaren voor de cursusdeelname van hun technisch personeel. Zo is het in 2005 gemakkelijker geworden om cursussen te vinden die aansluiten bij de eigen behoefte. Vervangingsproblemen zijn echter door de aantrekkende conjunctuur in belang toegenomen. Ook vinden steeds meer bedrijven dat het personeel onvoldoende geïnteresseerd is om opleidingen te volgen, wat een zorgelijke ontwikkeling is aangezien dit het succes van de opleidingsinspanningen in grote mate bepaalt.

De ontwikkeling van competenties wordt ook gestimuleerd wanneer werknemers flexibel worden ingezet voor taken die niet direct tot de eigen functie behoren. Dat vereist echter wel een bepaalde mate van inzetbaarheid. De inzetbaarheid is het grootst voor uitvoerende en leidinggevende technici. Bijna $70 \%$ van de bedrijven vindt dat het uitvoerend technisch personeel breed inzetbaar is, terwijl circa driekwart van de bedrijven aangeeft dat het leidinggevend technisch personeel voor verschillende werkzaamheden ingezet kan worden. Ondersteunende technici zijn volgens 59\% van de bedrijven breed inzetbaar. Daarentegen kunnen technisch opgeleide verkopers en het niet-technisch ondersteunend personeel veel minder vaak breed ingezet worden. De 
metalektrobedrijven maken echter ook in verschillende mate gebruik van de inzetbaarheid van de verschillende groepen personeel. Maar liefst 95\% van de bedrijven zet het uitvoerend technisch personeel vaak of af en toe flexibel in; $79 \%$ van de bedrijven maakt gebruik van de inzetbaarheid van hun leidinggevende technici en ook ondersteunende technici worden regelmatig flexibel ingezet. Daarentegen worden technisch opgeleide verkopers en het leidinggevend en ondersteunend niet-technisch personeel veel minder vaak breder ingezet.

Bedrijven geven aan dat de inzetbaarheid van het personeel vooral gestimuleerd kan worden door iemands probleemoplossend vermogen en de mate waarin iemand flexibel is te versterken. Maar ook vaktechnische vaardigheden, initiatief, communicatieve vaardigheden, het omgaan met veranderingen en zelfstandigheid kunnen sterk bijdragen aan de inzetbaarheid van het personeel. Goede IT vaardigheden zijn daarentegen veel minder belangrijk voor de inzetbaarheid van het personeel.

De mobiliteit van het personeel is de afgelopen jaren toegenomen. Deze mobiliteit heeft vooral betrekking op loopbaanstappen van technici naar andere technische functies op een hoger niveau. Horizontale mobiliteit bij technici komt wat minder voor, maar speelt toch in heel wat bedrijven een belangrijke rol. Doorstroom naar lagere functies ('demotie') komt daarentegen slechts in weinig bedrijven voor. De doorstroom van technici naar niet-technische functies is slechts gering. De mobiliteit naar niet-technische functies op een lager niveau is de laatste jaren ook afgenomen. Daarentegen is de horizontale doorstroom naar niet-technische functies op eenzelfde niveau toegenomen. Toch is het niveau van de mobiliteit volgens veel bedrijven nog onvoldoende. Uit gesprekken blijkt namelijk dat lang niet alle bedrijven tevreden zijn over de mate waarin het personeel doorstroomt naar andere functies.

\section{HRM-beleid in de Metalektro}

Metalektrobedrijven zijn niet alleen op technologisch gebied innovatief, maar gaan ook steeds innovatiever om met de mogelijkheden die het HRM-beleid biedt om een optimale ontwikkeling en inzet van het personeel te realiseren. Er is de laatste jaren sprake van een duidelijke toename van de inzet van verschillende HRM-instrumenten. Zo is het gebruik van HRM-instrumenten die gericht zijn op de communicatie tussen het bedrijf en de werknemers (beoordelings- en functioneringsgesprekken, geregeld werkoverleg) de laatste jaren steeds belangrijker geworden. Ook het aantal bedrijven dat hun personeel opleidingsfaciliteiten aanbied is in 2005 gestegen tot $85 \%$. Loopbaanplanning wordt eveneens voor steeds meer bedrijven van belang: het aantal bedrijven dat aandacht heeft voor de loopbaanplanning van hun technisch personeel is tussen 2002 en 2005 gestegen van slechts $8 \%$ in 2002 tot $37 \%$ in 2005 . Opmerkelijk is ook dat de inzet van EVC (erkenning van verworven competenties) de laatste paar jaar is verdubbeld, wat betekent dat er sprake is van een duidelijke 'take-off' van het EVC-beleid in de Metalektro. Maar ook het belang van het in kaart brengen van de kennis en kunde van het personeel neemt toe. In 2005 gebruikte al meer dan de 
helft van de bedrijven een competentie- of vaardighedenmatrix. Het spectaculairst is echter de toename van de functieroulatie: in 2002 had nog slechts $25 \%$ hier aandacht voor, terwijl in $200565 \%$ van de metalektrobedrijven aan functieroulatie deed. Dit illustreert opnieuw het grote belang dat bedrijven hechten aan het flexibel kunnen inzetten van hun personeel.

Steeds meer metalektrobedrijven gaan er ook toe over om persoonlijke ontwikkelingsplannen (POP's) voor hun personeel op te stellen. Het is opvallend dat de toename van POP's gepaard gaat met een daling van het aantal bedrijven dat gebruik maakt van een bedrijfsopleidingsplan (BOP), terwijl zowel de subsidies voor POP's als BOP's grotendeels afgeschaft werden. De toename van het aantal bedrijven dat POP's inzet duidt erop dat er sprake is van een individualisering van de opleidingsinspanningen.

Het gebruik van bepaalde HRM-instrumenten kan verschillende doelen hebben. Zo geven bedrijven aan dat EVC vooral als doel heeft de inzetbaarheid van medewerkers te vergroten en het personeelsverloop te verminderen . Een competentiemanagementsysteem blijkt daarentegen vooral gericht te zijn op het bevorderen van de doorstroom. Hetzelfde geldt voor een competentie- of vaardighedenmatrix, maar dit instrument wordt ook vaak ingezet om de inzetbaarheid te stimuleren. Met BOP's, POP's en opleidingsfaciliteiten streven metalektrobedrijven verschillende doelen tegelijk na: het verminderen van het personeelsverloop, het bevorderen van de inzetbaarheid en het ondersteunen van het beleid voor oudere $\left(45^{+}\right)$werknemers. Dit geldt ook voor HRM-instrumenten die gericht zijn op de communicatie met het technisch personeel (geregeld werkoverleg, functionerings-, scholings- en beoordelingsgesprekken). Bedrijven met een loopbaan- of mobiliteitscentrum proberen hiermee de doorstroom van het personeel te bevorderen en het beleid voor oudere werknemers te ondersteunen. Het uitwisselen van technisch personeel met andere bedrijfsvestigingen is daarentegen vooral gericht op het beperken van het personeelsverloop. Functieroulatie wordt in de meeste bedrijven ingezet om de inzetbaarheid te vergroten en het personeelsverloop te beperken, maar ook om het beleid voor oudere werknemers te ondersteunen. Functieroulatie kan er immers toe bijdragen dat het werk afwisselender en aantrekkelijker wordt, waardoor het verloop beperkt wordt, terwijl het ook bijdraagt aan de ontwikkeling van de brede inzetbaarheid. Het is opmerkelijk dat loopbaanplanning helemaal niet wordt ingezet om het beleid gericht op oudere werknemers te ondersteunen. Loopbaanplanning is dus meer gericht op het jongere personeel, en de bedrijven zetten dit HRM-instrument vooral in om het verloop te beperken, de inzetbaarheid te vergroten en de interne doorstroom te bevorderen.

Metalektrobedrijven houden in hun HRM-beleid erg weinig rekening met specifieke groepen werknemers. Slechts eenderde van de bedrijven besteedt speciale aandacht aan jongeren of leidinggevenden, terwijl maar $20 \%$ van de bedrijven oog heeft voor de positie van oudere werknemers of lager opgeleiden. Dit staat in schril contrast met de vergrijzing van het personeelsbestand en de mogelijke vervangingsproblemen in de komende jaren. De kleine groep bedrijven die wel specifiek aandacht besteedt aan hun 
oudere personeel doet dat vooral door het oudere personeel werk te laten doen waarbij de overdracht van kennis centraal staat en door het houden van loopbaangesprekken. In de praktijk blijkt echter dat er bij bedrijven die specifiek aandacht besteden aan hun oudere personeel meestal geen sprake is van een investeringsstrategie, maar van een soort behoudsstrategie, waarbij de nadruk ligt op het nog productief aan de slag houden van het oudere personeel tot het moment waarop ze met vroegpensioen kunnen.

$42 \%$ van de Metalektrobedrijven besteedt in beperkte mate aandacht aan de positie van het technisch personeel dat al langer in dienst is, terwijl een kwart van de bedrijven daar zelfs veel aandacht voor heeft. Bedrijven die op dit punt beleid voeren doen dat vooral door het houden van gesprekken waarin ze expliciet ingaan op de loopbaanmogelijkheden van het technisch personeel met veel dienstjaren. Daarnaast maken deze bedrijven interne vacatures aan iedereen bekend, of vergroten ze de loopbaanperspectieven van het technisch personeel dat al langer in dienst is.

\section{De Metalektro in de toekomst}

Het is voor de metalektrobedrijven van groot belang om goed inzicht te hebben in de wijze waarop de arbeidsmarkt zich de komende jaren zal ontwikkelen. Deze ontwikkelingen bepalen immers de context waarbinnen bedrijven hun HRM beleid moeten voeren. De komende jaren zal de werkgelegenheid in een aantal beroepsgroepen die belangrijk zijn voor de Metalektro krimpen. Zo wordt er voor de periode 2005-20I0 een krimpende werkgelegenheid verwacht voor metaalbewerkers, monteurs, bankwerkers en lassers, productiemedewerkers, elektromonteurs, werktuigbouwkundig ontwerpers en hoofden technische dienst en assembleurs. Het is opmerkelijk dat de uitbreidingsvraag voor de meeste administratieve functies positief is. Voor zowel administratief personeel als receptionisten en administratieve employés wordt er de komende jaren een beperkte werkgelegenheidsgroei verwacht.

Veel belangrijker dan de vraag naar personeel als gevolg van de ontwikkeling van de werkgelegenheid is echter de vervangingsvraag, die ontstaat doordat personeel vanwege pensionering of om een andere reden de arbeidsmarkt verlaat. Bij de meeste technische functies is er vanwege de vergrijzing van de beroepsbevolking sprake van een forse vervangingsvraag. De top-3 wordt gevormd door assembleurs (4,9\% per jaar), werktuigbouwkundig ontwerpers en hoofden technische dienst $(4,7 \%$ per jaar) en metaalbewerkers (4,6\% per jaar). Daarnaast zal circa $4 \%$ van de monteurs, bankwerkers en lassers, productiemedewerkers en elektromonteurs tot 2010 jaarlijks vervangen moeten worden. Bij de niet-technische functies is de vervangingsbehoefte in het algemeen lager dan bij de technische beroepen. Per saldo is er weinig verschil in het totale aantal baanopeningen (dat is de combinatie van uitbreidings- en vervangingsvraag) van de krimpende en de groeiende technische functies. Over de gehele linie bedraagt het aantal baanopeningen circa $4-5 \%$ op jaarbasis. Mede door de kleinere vervangings- 
behoefte, worden er minder baanopeningen verwacht voor niet-technische functies (circa 2-3\% per jaar).

In de praktijk zijn bedrijven bij een bepaalde vacature vaak op zoek naar mensen met een bepaalde opleidingsachtergrond. Daarom is het van belang om ook inzicht te hebben in de verwachte vraag en aanbodontwikkelingen voor specifieke opleidingen die voor bedrijven in de metaal en elektrotechnische sector van belang zijn. Voor slechts vier technische opleidingen is de verwachte uitbreidingsvraag negatief: VMBO metaal, MBO elektrotechniek, MBO werktuigbouw en mechanische techniek en $\mathrm{HBO}$ werktuigbouwkunde. Voor alle overige technische opleidingen is er sprake van een groeiende werkgelegenheid. De vervangingsvraag naar personeel met een technische opleiding op VMBO of $\mathrm{MBO}$ zal de komende jaren echter behoorlijk groot zijn. De vervangingsvraag naar mensen met een technische $\mathrm{HBO}$ opleiding is daarentegen wat lager, doordat het personeel op dit opleidingsniveau wat minder oud is dan de mensen met een beroepsopleiding op lager of middelbaar niveau.

Doordat de werkgelegenheid voor de meeste technische opleidingen de komende jaren niet toeneemt, is het totale aantal baanopeningen voor deze opleidingen gelijk aan de vervangingsvraag. Voor de technische opleidingen op VMBO en $\mathrm{MBO}$ niveau is het totale aantal baanopeningen daarom circa $4-5 \%$ per jaar. Voor de technische $\mathrm{HBO}$-opleidingen is het aantal baanopeningen wat kleiner.

Veel metalektrobedrijven hebben te maken met een nogal vergrijsd personeelsbestand, waardoor er de komende jaren sprake zal zijn van een grote uitstroom van personeel dat met pensioen gaat. Bij het uitvoerend en leidinggevend technisch personeel is de vergrijzing het sterkst. De uitstroom is kleiner voor de overige functiecategorieën. De vervanging van personeel dat de komende jaren met pensioen gaat kan tot problemen leiden. De verwachte problemen zijn het grootst bij het uitvoerende en leidinggevende personeel en de technisch opgeleide verkopers. Een kleiner aantal bedrijven verwacht grote problemen bij het vervangen van ondersteunende technici, niet-technische ondersteuners en niet-technisch leidinggevenden. De vervangingsproblemen voor uitvoerende technici hebben volgens de bedrijven vooral betrekking op de machinaal verspanende en plaatverwerkende beroepen, bankwerkberoepen en montageberoepen. Er worden veel minder problemen verwacht voor laag en ongeschoold personeel, personeel in de pijpverwerkende beroepen en elektromonteurs. De metalektrobedrijven gaan creatief om met de problemen die ze als gevolg van de pensioenuitstroom verwachten. $70 \%$ van de bedrijven probeert vervangingsproblemen te voorkomen door nieuwe werknemers aan te nemen die in het bedrijf zelf worden opgeleid. Meer dan de helft van de bedrijven probeert de inzetbaarheid van het personeel te vergroten door taakroulatie. Daarnaast nemen heel wat bedrijven nu al nieuw en goed opgeleid personeel aan, of scholen ze het huidige personeel om of bij om vervangingsproblemen voor te zijn. 
De innovatie in de Metalektro verandert de inhoud van de technische functies. Dit stelt eisen aan het te voeren personeelsbeleid. Het belangrijkste speerpunt in het toekomstige personeelsbeleid van de metalektrobedrijven is het bevorderen van de inzetbaarheid. Maar liefst $77 \%$ van de bedrijven noemt dit een belangrijk speerpunt voor de komende vijf jaar. Daarnaast geeft ruim de helft van de bedrijven aan de komende jaren meer aandacht te gaan besteden aan het verminderen van het verzuim. Verder gaan veel bedrijven de komende jaren aandacht besteden aan competentiemanagement, coachend leidinggeven, leeftijdsbewust personeelsbeleid en het verder stimuleren van de scholingsdeelname. Het realiseren van deze speerpunten verloopt natuurlijk lang niet altijd zonder problemen. Bedrijven verwachten vooral problemen te gaan ondervinden bij het verminderen van het verzuim, het voeren van een leeftijdsbewust personeelsbeleid en het bevorderen van de inzetbaarheid van hun personeel. Het bevorderen van de inzetbaarheid zal volgens de bedrijven zelf vooral belemmerd worden door tekortschietende kennis en vaardigheden, onvoldoende leervermogen of een te weinig flexibele houding.

Om enig inzicht te krijgen in de wijze waarop bedrijven met hun opleidingsbeleid kunnen reageren op de ontwikkelingen in de komende jaren, is aan de bedrijven gevraagd om aan te geven aan welke competenties meer aandacht moet worden besteed. $60 \%$ van de bedrijven vindt dat er in de toekomst nog meer aandacht moet worden besteed aan vaktechnische vaardigheden. Ook vinden veel bedrijven dat er meer aandacht moet komen voor cursussen en trainingen communicatieve vaardigheden en probleemoplossend vermogen. Deze competenties kunnen overigens natuurlijk ook voor een groot deel op informele wijze worden aangeleerd. Uit de ontwikkelingen van afgelopen jaren valt af te leiden dat probleemoplossend vermogen en communicatieve vaardigheden echte sleutelcompetenties zijn geworden. Het is opmerkelijk dat het percentage bedrijven dat in hun toekomstige opleidingsbeleid meer aandacht wil besteden aan het vergroten van de flexibiliteit van hun technisch personeel is afgenomen. Dit duidt erop dat steeds meer bedrijven zich realiseren dat flexibiliteit niet noodzakelijk via formele cursussen of trainingen aangeleerd hoeft te worden, maar eerder door middel van functieroulatie, e.d.. Een andere opmerkelijke ontwikkeling is het toenemende belang van procesgericht werken. Dit duidt erop dat de veranderende productieprocessen in de metalektrobedrijven er toe geleid hebben dat procesgericht werken een cruciale succesfactor wordt.

\section{Agenda voor de Toekomst}

In de Arbeidsmarktmonitor Metalektro 2004 is een Agenda voor de Toekomst opgesteld voor het HRM beleid in de metalektrosector, met als motto: competent en breder inzetbaar. Deze Agenda van de Toekomst omvat de volgende speerpunten:

1. De POFI-Agenda, gericht op het versterken van het competentieniveau van het personeel, met betrekking tot de vier compe- 
tenties waaraan bedrijven in de toekomst vooral behoefte hebben:
a. probleemoplossend vermogen;
b. omgaan met veranderingen;
c. flexibiliteit;
d. initiatief.

2. Opleidingen en trainingen moeten beter gaan aansluiten op de competenties die bedrijven (in de toekomst) nodig hebben.

3. Naast formele cursussen en trainingen zou er meer aandacht moeten komen voor informele manieren van kennisverwerving, zoals coaching, en 'learning by doing'. Wanneer deze informele scholing gecombineerd wordt met formele cursussen ontstaat er in de bedrijven een 'leerrijke werkomgeving' waarin leren en werken een strategisch geheel vormen.

4. Het opscholen van de instroom van schoolverlaters naar het voor een optimaal functioneren vereiste competentieniveau.

5. Het aandacht blijven houden voor laagopgeleide en oudere werknemers. Wanneer deze groepen niet kunnen worden bijgeschoold tot een hoger niveau, moet er zorg voor gedragen worden dat ze voldoende breed inzetbaar zijn en wel beschikken over de competenties die de bedrijven op de lagere functieniveaus nodig hebben.

6. Het vergroten van de doorstroom van het personeel om de brede inzetbaarheid van het personeel te vergroten. Doorstroom van ouder personeel naar minder belastende functies kan er toe bijdragen dat oudere werknemers langer productief aan het werk kunnen blijven.

7. Verdere uitbouw van HRM-instrumenten die de brede inzetbaarheid bevorderen: loopbaan/carrière planning, functieroulatie, EVC, coachend leidinggeven, competentiemanagement en uitwisseling van werknemers.

De geformuleerde speerpunten in de Agenda van de Toekomst blijven ook in de komende jaren van groot belang. Aan het eind van dit rapport wordt ingegaan op de vraag of de metalektrobedrijven het afgelopen jaar op deze speerpunten vooruitgang hebben geboekt. Bij de POFI-agenda is er sprake van enige vooruitgang omdat de cursusdeelname gericht op het verbeteren van het probleemoplossend vermogen van het personeel toeneemt. De deelname aan cursussen en trainingen gericht op de andere drie POFI competenties is echter niet toegenomen. Veel bedrijven realiseren zich echter wel dat deze competenties voor een groot deel informeel worden aangeleerd. In dat kader is het ook erg positief dat steeds meer bedrijven de flexibiliteit van hun personeel proberen te vergroten door middel van functieroulatie. Toch zouden bedrijven er goed aan doen om ook in het formele opleidingsbeleid meer aandacht te gaan besteden aan de verdere ontwikkeling van de genoemde POFI competenties.

Andere positieve ontwikkelingen zijn de groeiende betrokkenheid van werknemers bij hun eigen cursusdeelname, de individualisering van het opleidingsbeleid (meer POP's, minder BOP's) en de verbreding van de opleidingsinspanningen. Een positieve ontwikkeling is ook dat steeds meer bedrijven gaan inzien dat informeel leren en 
'learning by doing' belangrijke manieren zijn om het personeel competenties te laten verwerven. Bedrijven beseffen ook dat er een wisselwerking bestaat tussen formeel en informeel leren, waarbij het formele leren vaak impulsen geeft om op informele wijze verder te gaan leren. Dit betekent dat bedrijven nu al bezig zijn met het creëren van een leerrijke werkomgeving, waarbij verschillende leervormen en het dagelijkse werk één geheel vormen.

Vanwege de vergrijzing van het personeelsbestand is het echter ook van groot belang dat bedrijven voldoende aandacht blijven houden voor het competentieniveau van de instromende schoolverlaters. Dat gebeurt bijvoorbeeld door het opbouwen van goede relaties met het onderwijsveld. Toch vinden de bedrijven nog vaak dat er bij de instromende schoolverlaters sprake is van competentietekorten en dat de scholen daarom meer aandacht moeten gaan besteden aan vaktechnische vaardigheden, probleemoplossend vermogen en flexibiliteit. Deze tekortschietende competenties zullen echter ook voor een deel door de bedrijven zelf moeten worden bijgespijkerd. Dit blijkt in de praktijk overigens al veel voor te komen. Niet alleen door het bijbrengen van bedrijfsspecifieke vaardigheden tijdens de eerste tijd dat een schoolverlater in dienst is, maar ook door VMBO-schoolverlaters aan te nemen, die in het kader van hun BBLopleiding verder door de bedrijven zelf worden opgeschoold.

Een ander punt dat de komende jaren meer aandacht verdient is het HRM-beleid gericht op laagopgeleide en oudere werknemers. Het feit dat in 2005 slechts $20 \%$ van de bedrijven expliciet aandacht besteed aan de positie van oudere werknemers en dat de bedrijven die dat wel doen nog onvoldoende bezig zijn met het daadwerkelijk investeren in hun oudere personeel staat in schril contrast met de vergrijzing en het opschuiven van de leeftijd waarop werknemers met pensioen kunnen gaan. De geringe aandacht voor laagopgeleide werknemers kan in de toekomst leiden tot ernstige competentietekorten.

De interne mobiliteit van het technische personeel naar andere technische functies blijft in 2005 op eenzelfde niveau als in voorgaande jaren, maar de mobiliteit van technici naar niet-technische functies is toegenomen. Dit laatste kan verklaard worden doordat meer bedrijven deze mobiliteit actief stimuleren of hun personeel opleiden met de bedoeling de mobiliteit te vergroten. Toch vinden veel bedrijven de interne mobiliteit van hun personeel nog te laag. Bovendien is er in bijna de helft van de metalektrobedrijven nog helemaal geen sprake van personeel dat doorstroomt.

Op het vlak van de uitbouw van HRM-instrumenten die de brede inzetbaarheid bevorderen is er de afgelopen jaren een behoorlijke vooruitgang geboekt. In vergelijking met vorige jaren zijn er in 2005 veel meer metalektrobedrijven met functieroulatie en loopbaanplanning. Ook het gebruik van een competentie- of vaardighedenmatrix en EVC is de afgelopen jaren sterk toegenomen. Dit geldt ook voor de communicatie met het personeel: steeds meer bedrijven voeren beoordelingsgesprekken of functioneringsgesprekken met hun personeel en steeds meer bedrijven houden geregeld 
werkoverleg. Dit wijst erop dat steeds meer bedrijven zijn gaan inzien dat ook een goede communicatie met het personeel bijdraagt aan de inzetbaarheid van mensen.

De resultaten van deze arbeidsmarktmonitor bevestigen in grote mate de prioriteiten die in de Agenda van de Toekomst zijn verwoord. Toch zijn er ook enkele opvallende uitkomsten, die leiden tot bepaalde aanvullingen op de Agenda van de Toekomst. Allereerst blijken de POFI competenties probleemoplossend vermogen en flexibiliteit niet alleen de directe productiviteit van het personeel te vergroten, maar ook van grote invloed te zijn op de inzetbaarheid van het personeel. Dit vergroot de noodzaak voor bedrijven om hun formele en informele opleidingsinspanningen te richten op deze competenties. Daarnaast zien steeds meer bedrijven goede communicatieve vaardigheden en het procesgericht kunnen werken als sleutelcompetenties, die van groot belang zijn voor de arbeidsproductiviteit. Deze competenties moeten een meer prominente plaats krijgen in het opleidingsbeleid. Ook blijkt dat meer metalektrobedrijven hebben aangegeven dat het belang van een goede klantgerichtheid van hun personeel de komende jaren zal toenemen. Deze klantgerichtheid verdient derhalve een aparte plaats in de Agenda voor de Toekomst. Ten slotte ervaren veel bedrijven momenteel een gebrek aan personeel met voldoende werkervaring. Dit probleem zal in de toekomst nog dringender worden wanneer een groot deel van het oudere personeel met pensioen zal gaan. Bedrijven zullen er daarom steeds meer voor moeten gaan kiezen om personeel zonder werkervaring in dienst te nemen die ze vervolgens zelf verder moeten ontwikkelen. Daarnaast kunnen bedrijven er natuurlijk ook voor zorgen dat leerlingen/studenten tijdens hun opleiding werkervaring opdoen, door het aanbieden van stageplaatsen, gerichte praktijkopdrachten of door op andere manieren de relaties met het onderwijsveld te intensiveren. 


\section{Innovatie en marktontwikkelingen in de Metalektro}

"Wat de klant wil, dat doen we."

"We zijn continu op zoek naar nieuwe producten en nieuwe toepassingen voor onze bestaande producten. Die zoektocht leidt tot grote veranderingen in de functies van ons technisch personeel."

"De invoering van lean manufacturing is bij ons een ingrijpend proces. We zijn er constant mee bezig, en hoewel we het eindpunt nog niet bereikt hebben, proberen we ook nu al onze productie zo 'lean' mogelijk te organiseren."

"De verplaatsing van onze productie-activiteiten naar het buitenland is niet zonder problemen verlopen. We hebben de eerste jaren behoorlijk wat problemen gehad. Het is een proces van jaren geweest voordat we in het buitenland voldoende kennis en kwaliteitsbewustzijn ter beschikking hadden."

"We opereren ook steeds meer op de markt in Azië en dat vergt heel wat flexibiliteit van ons personeel."

De uitspraken van bedrijven illustreren de grote dynamiek waarmee de metalektrobedrijven te maken hebben. In dit hoofdstuk gaan we in op de marktontwikkelingen en de innovatie in de Metalektro. We beginnen met de conjuncturele ontwikkelingen. Vervolgens kijken we naar innovatie: welke technologische en organisatorische veranderingen voeren de bedrijven door en welke gevolgen heeft dat voor het personeel? Daarna gaan we in op de internationalisering van de afzetmarkten. We sluiten het hoofdstuk af met een vergelijking van de Nederlandse Metalektro met de metalektrosectoren in enkele ons omringende landen. 


\subsection{Conjuncturele ontwikkelingen}

De recessie waarmee de metalektrosector de afgelopen jaren te maken had, lijkt voorbij. Figuur I.I laat zien dat er voor 2006 voor alle sectoren binnen de Metalektro weer groei wordt verwacht. Toch zal deze groei zich niet vertalen in een stijgende werkgelegenheid. Evenals in voorgaande jaren verwachten de metalektrobedrijven dat de werkgelegenheid in 2006 weer verder zal gaan dalen. Dit weerspiegelt de structurele teruggang van de werkgelegenheid in de Metalektro, die mede veroorzaakt wordt door de productiviteitsstijgingen die veel bedrijven realiseren. Dat er steeds meer bereikt kan worden met minder personeel wordt mogelijk doordat de Metalektro een hoogtechnologische sector is, waar de productieprocessen continu verbeterd worden door technologische en organisatorische innovaties.

\section{Figuur 1.1}

Ontwikkeling van het afzetvolume in de verschillende sectoren binnen de Metalektro, 2003-2005 (indexcijfer, 2002=100)

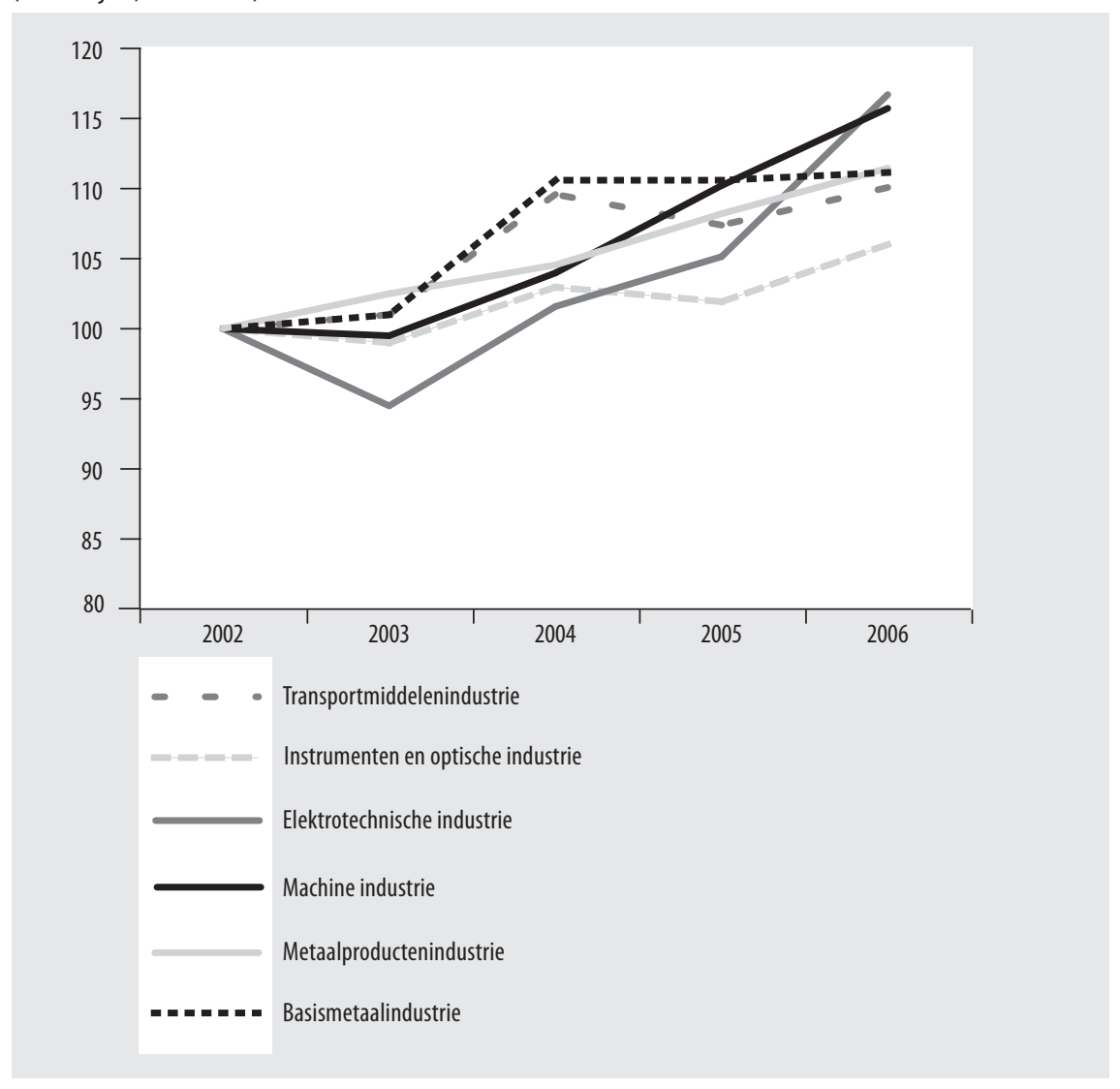

Bron: FME-CWM Conjunctuurenquête, 2003-2005 
De ontwikkeling van de afzet in 2005 verschilde sterk tussen de verschillende sectoren binnen de Metalektro. Zo was er in 2005 in de basismetaal helemaal geen sprake van een groeiende afzet en daalde de afzet in de instrumenten en optische industrie en de transportmiddelen. Daarentegen was er sprake van een behoorlijke stijging van het afzetvolume in de metaalproductenindustrie en de machine industrie. In de machine industrie werd zelfs een afzetstijging van $6 \%$ gerealiseerd. Dat de ontwikkelingen zo sterk verschillen tussen de sectoren binnen de Metalektro betekent dat de conjuncturele opleving in 2004 zich niet over de gehele linie heeft doorgezet. Daarbij is het opmerkelijk dat de bedrijven in sectoren waar de afzet stagneerde dit een jaar eerder niet hadden voorspeld. Dit zou erop kunnen duiden dat de dalende afzet in 2005 veroorzaakt is door onverwachte ontwikkelingen.

De vooruitzichten voor 2006 zijn, zoals gezegd, weer gunstig te noemen. In alle sectoren verwachten de bedrijven weer een groeiende afzet. Het valt wel op dat de groei vooral geconcentreerd is in de high-tech sectoren van de Metalektro. Zo bedraagt de verwachte afzetgroei in de basismetaal slechts $0,5 \%$. Ook in de transportmiddelenindustrie en de metaalproductensector blijft de verwachte afzetstijging beperkt (respectievelijk 2,5\% en 3\%). High-tech sectoren als de elektrotechnische industrie, de instrumenten en optische industrie en de machine industrie profiteren daarentegen veel meer van de conjuncturele opleving in 2006. De elektrotechnische industrie verwacht zelfs II\% meer afzet te realiseren dan in 2005 .

De verbetering van de conjuncturele situatie in 2006 leidt niet tot een stijging van de werkgelegenheid. De Metalektro als geheel verwacht dat de werkgelegenheid in 2006 met $2,5 \%$ zal dalen. De bedrijven in de basismetaal en de instrumenten en optische industrie verwachten de grootste daling van de werkgelegenheid (respectievelijk $-6 \%$ en $-9 \%)$. In de machine industrie verwacht men daarentegen een beperkte groei van de werkgelegenheid met $2,5 \%$. Opmerkelijk is ook dat in de elektrotechnische industrie de II\% afzetgroei gepaard gaat met een werkgelegenheidskrimp van $3 \%$. Dit betekent dat elektrotechnische bedrijven verwachten een aanzienlijke productiviteitsstijging te gaan realiseren.

\subsection{Innovaties}

De metalektrosector is een dynamische bedrijfssector. De metalektrobedrijven hebben te maken met uiteenlopende veranderingen in hun productietechnologie, de producten die ze maken en de wijze waarop het werk georganiseerd wordt. Deze dynamiek heeft vanzelfsprekend ook gevolgen voor de functies van het technisch personeel. 


\section{Technologische innovaties}

Maar liefst 94\% van de bedrijven in de Metalektro verwacht dat er de komende vijf jaar ingrijpende technologische veranderingen zullen plaatsvinden. Om welke veranderingen gaat het dan vooral? Figuur I.2 laat zien dat de belangrijkste vernieuwingen betrekking hebben op productinnovaties. Bijna $80 \%$ van de bedrijven verwacht dat de producten die ze maken in de komende vijf jaar ingrijpend zullen veranderen.

\section{Figuur 1.2}

Verwachte technologische innovaties in de komende vijf jaar (\% bedrijven)

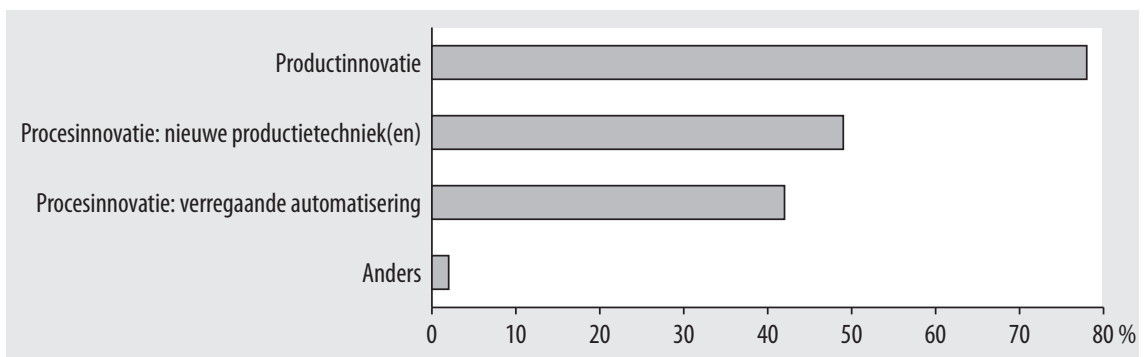

Bron: ROA/Werkgeverspanel Metalektro 2005

Uit een aantal gesprekken met metalektrobedrijven komt ook duidelijk naar voren dat er de komende jaren heel wat productinnovaties zullen plaatsvinden. Zo gaat een bedrijf dat bepaalde metaalproducten maakt zich steeds meer toeleggen op producten waarin meer elektronica geïntegreerd wordt. Volgens de personeelsmanager bestaan dat soort producten momenteel al wel, maar zijn ze nog veel te duur voor de gemiddelde consument: "We gaan die producten daarom proberen de komende jaren steeds betaalbaarder te maken”. De HRM-manager van een high-tech electrotechnisch bedrijf ziet de technologische innovaties als noodzakelijk gevolg van de sterker wordende concurrentie: "Om ons marktaandeel te behouden moeten we continu opereren op de grens van wat technologisch mogelijk is. We zijn daarom ook volop bezig met nieuwe producten waarbij we software leveren die de klanten beter ondersteunt. We proberen grensverleggend bezig te zijn door te zoeken naar multidisciplinaire oplossingen". Andere bedrijven geven aan dat de markt steeds meer verschillende soorten producten vraagt. Een manager in een bedrijf wat volgens haar 'medium'-tech is, omschrijft dat als volgt: "Vroeger hadden we van een bepaald soort product drie varianten. Nu zijn dat er al ruim 20 en onze verwachting is dat dat nog zal stijgen".

Ook de manier waarop de bedrijven hun producten maken zal volgens veel metalektrobedrijven veranderen: $42 \%$ van de bedrijven verwacht verregaande automatisering van de productieprocessen in de komende vijf jaar. Daarnaast verwacht bijna de helft van de metalektrobedrijven de komende vijf jaar procesinnovaties in de vorm van nieuwe productietechnieken door te gaan voeren. Dit is duidelijk meer dan in het jaar daarvoor. In 2004 plande nog slechts $42 \%$ van de bedrijven de invoering van een nieuwe productietechniek. Tussen de verschillende regio's zijn er op het vlak van de 
technologische dynamiek enige verschillen. Zo geven metalektrobedrijven in de regio Zuid, waar veel high-tech bedrijven gevestigd zijn, vaker aan dat ze bepaalde technologische innovaties gaan doorvoeren dan metalektrobedrijven uit andere regio's.

Enkele uitspraken van bedrijven illustreren dat de procesinnovaties behoorlijk ingrijpend zijn: "Vroeger waren we vooral bezig met echt handwerk: vormen, gieten en plooien. $\mathrm{Nu}$ zijn we veel specialistischer bezig en richten we ons op het assembleren van onderdelen die we van andere bedrijven aankopen. We automatiseren en robotiseren volop, om zo te besparen op de loonkosten". Een ander bedrijf benadrukt de wisselwerking tussen product- en procesinnovatie: "We willen een steeds grotere toegevoegde waarde realiseren in onze producten en diensten en daarop stemmen we onze productielijnen af". Een derde bedrijf ziet vooral veranderingen in de productieprocessen als gevolg van productinnovatie: "We streven ernaar om de klant steeds meer een totaalpakket te bieden, waarbij we zowel de machines als het bijbehorende productiemateriaal leveren".

Uit de gesprekken met metalektrobedrijven komt ook duidelijk naar voren dat niet alle veranderingen in productieprocessen het directe gevolg zijn van technologische innovaties. Het blijkt dat ook het realiseren van kostenbesparingen een belangrijke reden is om productieprocessen te veranderen. Een HRM-manager van een bedrijf waarin de technologische veranderingen in de productietechniek beperkt blijven geeft aan dat het bedrijf "de productie wel steeds verder moet optimaliseren om de kosten in de hand te houden". Enkele andere bedrijven gaven in de interviews te kennen dat ze bezig zijn of binnenkort gaan starten met kostenbesparende programma's (bijvoorbeeld 'lean manufacturing') of programma's waarbij de verbetering van kwaliteit en efficiency centraal staat ('six sigma'). De invoering daarvan blijkt vaak meerdere jaren in beslag te nemen: "We zijn er al een half jaar mee bezig, en we denken dat het nog wel twee jaar zal duren voordat we onze doelen hebben bereikt."

\section{Organisatorische ontwikkelingen}

Technologische innovaties staan zelden op zichzelf, maar vereisen vaak ook een andere manier van werken. Het is dan ook niet verwonderlijk dat het overgrote deel van de bedrijven in de Metalektro (92\%) verwacht dat, naast technologische innovaties van producten en productieprocessen, de organisatie van hun productieprocessen de komende jaren zal veranderen. Het kan daarbij gaan om veranderingen in de structuur van de organisatie, maar ook om veranderingen in de wijze waarop het werk wordt georganiseerd.

Welke organisatorische vernieuwingen gaan er volgens de metalektrobedrijven in de komende vijf jaar plaatsvinden? Figuur I.3 geeft, in volgorde van belangrijkheid, een overzicht van de organisatorische veranderingen die metalektrobedrijven de komende vijf jaar zullen gaan doorvoeren. 
Maar liefst 55\% van de bedrijven verwacht dat ze de komende vijf jaar steeds vaker een beroep zullen doen op de flexibiliteit van hun personeel. Volgens bedrijven die deelnamen aan interviews is dat een grote verandering ten opzichte van vroeger: "We hadden vroeger mensen in dienst die hun hele leven hetzelfde eentonige werk deden en daarmee tevreden waren. We hebben momenteel nog een groep oudere werknemers in dienst met een dergelijke houding. Voor die mensen is elke verandering er een te veel doordat ze volledig vastgeroest zijn in hun functie. Gelukkig hebben de jongere mensen in ons bedrijf een veel flexibelere instelling. Die werknemers zijn juist op zoek naar afwisseling en zijn niet eens bereid om voor langere tijd stom eentonig werk te doen".

Figuur 1.3

Verwachte organisatorische veranderingen in de komende vijf jaar (\% bedrijven)

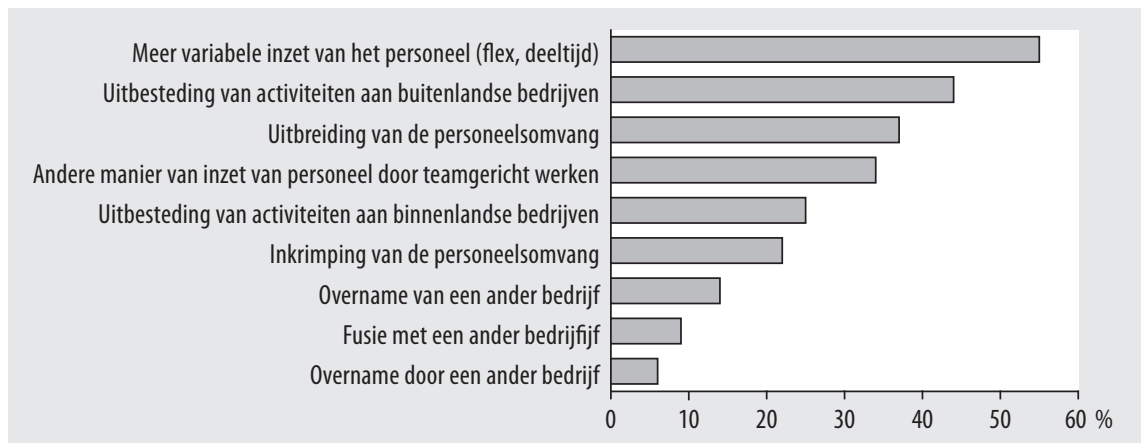

Bron: ROA/Werkgeverspanel Metalektro 2005

Uit interviews met bedrijven uit het werkgeverspanel blijkt ook dat de grotere behoefte aan flexibiliteit vaak het gevolg is van de toenemende internationale concurrentie. Een HRM-manager bij een bedrijf dat toeleverancier is van de automobielindustrie omschrijft dat als volgt: "we moeten steeds steviger met China concurreren, en daarom is het van groot belang dat ons personeel zich flexibel opstelt. Vroeger was dat in beperkte mate ook wel nodig, maar het wordt steeds kritieker dat het personeel zich flexibel gedraagt". Toch ervaren niet alle metalektrobedrijven een toenemende internationale concurrentie. Een personeelsfunctionaris: "Bij ons valt de concurrentie nog mee, omdat er wereldwijd maar enkele aanbieders zijn die onze producten maken. We zijn ook niet zo gevoelig voor schommelingen in de conjunctuur, omdat we aan heel uiteenlopende sectoren producten leveren".

Een tweede belangrijke organisatorische verandering is het uitbesteden van activiteiten aan buitenlandse bedrijven, de zogenaamde "off-shoring". Maar liefst $44 \%$ van de metalektrobedrijven verwacht dat ze de komende vijf jaar een deel van hun activiteiten aan buitenlandse vestigingen of andere bedrijven zullen uitbesteden. Binnen de metalektrosector wordt er heel verschillend gedacht over de noodzaak van het verplaatsen van activiteiten naar het buitenland. In een elektrotechnisch bedrijf vindt de personeelsmanager dat het "allemaal veel te kort door de bocht gaat" en "helemaal 
niet creatief is" om de productie gedeeltelijk te verplaatsen naar Slowakije. Toch kan ze wel begrijpen dat er kosten bespaard moeten worden, maar dat kan ook op een andere manier: "je kunt de productie ook gewoon anders gaan organiseren".

Bij een ander bedrijf denkt men heel anders over het nut van het produceren in het buitenland. Een personeelsmanager verwacht dat de trend zal zijn dat er steeds meer zal worden uitbesteed: "Dat is ook noodzakelijk, omdat omdat bepaalde productietechnieken in Nederland gewoon te duur zijn geworden. Soms is het bedrijfseconomisch zelfs verstandiger voor ons dat we bepaalde producten helemaal niet meer zelf maken, maar gewoon inkopen". Dat veel bedrijven hun productie (gedeeltelijk) naar het buitenland verplaatsen betekent echter niet dat dit altijd zonder problemen gaat. Zo had een bedrijf dat actief is in de metaalproductensector in het begin grote problemen bij het verplaatsen van de reparatie-afdeling naar Polen: "de opleiding en het kwaliteitsbewustzijn van Poolse vakkrachten schoot nogal eens tekort en het was regelmatig nodig dat Nederlands personeel op locatie ging bijspringen".

Een ander bedrijf geeft daarentegen juist aan dat het uitbesteden van werk meestal vrij goed verloopt. De HRM-manager vertelt dat werk wordt uitbesteed wanneer "het bij ons echt te druk wordt". Ze benadrukt echter wel het belang van een goede regie: "We vinden het heel belangrijk dat we zelf de touwtjes in handen houden wanneer we werkzaamheden uitbesteden. We merken dat dat veel problemen voorkomt". Een andere personeelsmanager benadrukt dat de gevolgen van off-shoring voor een deel onzeker zijn: "We denken erover om delen van de productie uit te gaan besteden, maar welke gevolgen dat heeft dat weten we nog niet. Het hangt er allemaal van af welke activiteiten we uiteindelijk overhouden, welke eisen we gaan stellen aan onze leidinggevenden en wat we vragen van het uitvoerend technisch personeel. "

Vaak wordt gedacht dat organisatorische veranderingen een negatieve invloed hebben op de omvang van het personeelsbestand. Het blijkt echter dat dit voor veel bedrijven niet het geval is: $37 \%$ van de metalektrobedrijven verwacht voor de komende jaren juist een uitbreiding van hun personeelsbestand. "We hebben steeds meer personeel nodig door alle ontwikkelingen die op ons afkomen", vertelt een HRM-manager van een high-tech bedrijf. Daarnaast geeft ruim een derde van de bedrijven aan dat ze niet met minder personeel gaan werken, maar dat ze hun personeel wel op een andere wijze willen gaan inzetten, door steeds teamgerichter te gaan werken.

Een kwart van de bedrijven verwacht dat ze de komende jaren activiteiten uit gaan besteden aan binnenlandse bedrijven. De overige genoemde organisatorische veranderingen zijn telkens op een beperkter deel van de bedrijven van toepassing. Het gaat hier om: Een inkrimping van de personeelsomvang (22\%), een overname van een ander bedrijf (I4\%), een fusie met een ander bedrijf (9\%) of een overname door een ander bedrijf $(6 \%)$. 


\section{Veranderende functies}

De dynamiek die gepaard gaat met innovaties heeft natuurlijk ook gevolgen voor de functies van het personeel. Zo verwacht maar liefst $92 \%$ van de metalektrobedrijven dat de technologische innovaties en organisatorische veranderingen de komende jaren ook gevolgen hebben voor de inhoud van de technische functies in het bedrijf. Figuur I. 4 geeft een overzicht van de veranderingen in de functies van het technisch personeel die de bedrijven voor de komende vijf jaar verwachten.

Figuur 1.4

Verwachte veranderingen in de functies van het technisch personeel in de komende vijf jaar (\% bedrijven)

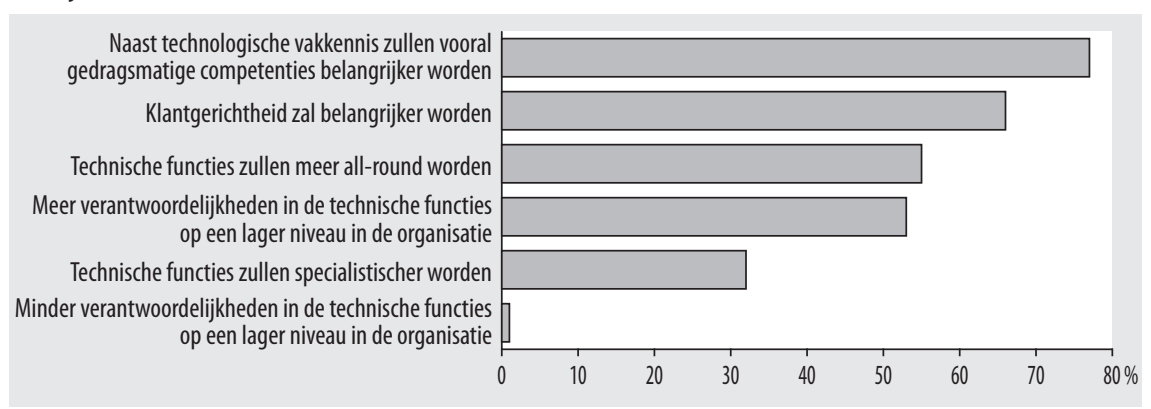

Bron: ROA/Werkgeverspanel Metalektro 2005

De belangrijkste gevolgen van technologische en organisatorische innovaties voor het technisch personeel zijn het belangrijker worden van gedragsmatige competenties en de grotere nadruk op klantgerichtheid. De laatste jaren erkennen steeds meer bedrijven dat het belangrijker wordt dat het personeel naast vakinhoudelijke kennis en vaardigheden ook over voldoende gedragsmatige competenties beschikt. In 2004 verwachtte $72 \%$ van de bedrijven dat gedragsmatige competenties de komende jaren steeds belangrijker worden voor het technisch personeel. In 2005 stijgt dit aandeel tot $77 \%$. Een bedrijf dat actief is in de metaalproductensector denkt dat vooral het probleemoplossend vermogen van het personeel steeds belangrijker zal worden: "Doordat we steeds meer moeten concurreren en doordat onze nieuwe directeur op een frisse manier tegen de ontwikkelingen aankijkt hebben we er steeds meer oog voor dat ons personeel over voldoende capaciteiten beschikt om probleemoplossend bezig te zijn”.

De innovatiedynamiek leidt ook tot een grotere nadruk op klantgerichtheid: Maar liefst tweederde van de bedrijven in de Metalektro geeft aan dat in de functies van hun technisch personeel het belang van een goede klantgerichtheid de komende jaren verder zal toenemen. Het toenemende belang van klantgericht werken heeft waarschijnlijk ook te maken met de toenemende nationale en internationale concurrentie waarmee veel metalektrobedrijven worden geconfronteerd. Om succesvol te zijn op markten met veel concurrentie, is het van groot belang dat bedrijven hun producten 
en diensten zoveel mogelijk kunnen afstemmen op de wensen van de klant. Enkele concrete uitspraken van personeelsmanagers in de metalektrobedrijven: "We moeten concurrerend blijven door te komen met nieuwe producten die gericht zijn op de wensen van onze klanten" en "onze klanten vragen dat we steeds sneller kunnen leveren, daarom proberen we de levertijd de komende tijd te verkorten van I3 naar 3 weken".

Leiden technologische innovaties en organisatorische vernieuwingen er toe dat de functies van het technisch personeel specialistischer of juist meer all-round worden? Het blijkt dat de metalektrobedrijven op dit punt sterk verdeeld zijn. Dit zou er op kunnen duiden dat de invloed van innovaties op de mate waarin technische functies meer specialistisch of juist generieker worden sterk afhangt van het soort bedrijf. $55 \%$ van de bedrijven verwacht dat de technische functies in het bedrijf meer all-round zullen worden, terwijl $32 \%$ van de bedrijven verwacht dat de technische functies in het bedrijf juist specialistischer zullen worden. Op dit punt bestaan er wel enkele opmerkelijke duidelijke regionale verschillen. Zo verwachten bedrijven in de regio Noord/ Oost vaker dat de technische functies in het bedrijf specialistischer zullen worden $(42 \%)$ dan bedrijven uit de regio West (21\%) of Zuid (33\%). Enkele gesprekken met bedrijven in Zuid-Nederland bevestigen dit beeld. Een HRM-manager denkt dat de grotere nadruk op kostenbesparingen steeds meer van het personeel vereist: "naast een goede vakkennis moeten ze ook kunnen samenwerken, beter kunnen communiceren en effectiever kunnen plannen". Een personeelsmanager van een ander bedrijf geeft aan dat mensen steeds meer kennis moeten hebben om bij het bedrijf aan de slag te kunnen gaan: "we letten daarom steeds meer op de vooropleiding van nieuw personeel”. Maar ook in andere regio's leiden de ontwikkelingen ertoe dat er meer kennis nodig is. Een bedrijf in de regio Noord/Oost dat 'lean manufacturing' doorvoert heeft het over ingrijpende veranderingen in de functies van het technisch personeel: "We hebben eigenlijk meer kennis nodig in alle functies. Daarnaast leidt lean manufacturing tot een andere organisatie van het werk, een andere manier van planning en nieuwe manieren waarop we onze mensen aansturen."

Er is volgens de bedrijven sprake van een duidelijke verschuiving van de verantwoordelijkheden. $53 \%$ van de bedrijven verwacht dat de verantwoordelijkheden in de technische functies op een lager niveau in de organisatie zullen toenemen. Daarentegen verwacht slechts I\% van de bedrijven dat de verantwoordelijkheden op de lagere functieniveaus kleiner zullen worden. De verschuiving van verantwoordelijkheden blijkt een structurele trend te zijn. Ook in 2004 gaf de meerderheid van de bedrijven aan dat de verantwoordelijkheden op de lagere niveaus groter zullen worden. Deze ontwikkeling doet zich ook in andere landen voor. In de Angelsaksische landen wordt in dit verband vaak gesproken van de "high performance workplace", die zich kenmerkt door een hoge autonomie van multi-inzetbaar uitvoerend personeel dat in toenemende mate in teamverband werkzaam is. Uit de interviews met bedrijven uit het werkgeverspanel blijkt dat heel wat Nederlandse metalektrobedrijven zich terdege bewust zijn van het nut van de ontwikkeling van de high performance workplace. 
Een HRM-manager stelt dat "de gevolgen van de ontwikkelingen in het bedrijf van hoog tot laag voelbaar zullen zijn. Het is daarom van groot belang dat al ons personeel effectief in teamverband kan samenwerken". Een ander bedrijf vindt dat "het personeel steeds beter moet leren om effectief in multidisciplinaire projectteams bezig te zijn". Het is daarbij wel van groot belang dat bedrijven ook goed duidelijk maken waarom bepaalde veranderingen nodig zijn: "Je kunt een cultuuromslag niet bereiken als de werknemers niet weten waarom ze zich anders moeten gaan opstellen". Dat blijkt overigens niet altijd even makkelijk te realiseren. Een personeelsmanager: "Het kost heel wat moeite om iedereen van het nut ervan te overtuigen. Daarom proberen we zoveel mogelijk draagvlak te creëren, bijvoorbeeld door commissies samen te stellen waarin de veranderingen en de implementatie daarvan uitgebreid worden besproken".

\subsection{Internationalisering}

De Nederlandse metalektrobedrijven zijn volop actief op een groot aantal internationale afzetmarkten. Uit recente cijfers van het CBS die betrekking hebben op de gehele Nederlandse metaal en elektrotechnische sector blijkt dat buitenlandse afzetmarkten steeds belangrijker worden. Figuur I.5 laat zien dat in de laatste jaren het exportaandeel van de omzet steeds verder is toegenomen. Het exportaandeel steeg van $56 \%$ in 2003 tot $61 \%$ in 2005 .

Figuur 1.5

Omzetaandeel Metalektro naar afzetmarkt

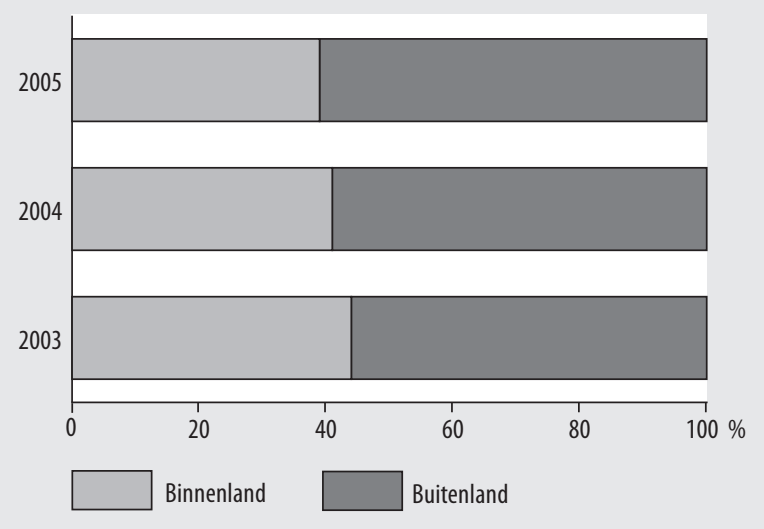

Bron: CBS

Er zijn echter wel enkele opmerkelijke verschillen in de ontwikkeling van het omzetaandeel tussen de verschillende bedrijfstakken binnen de metaal en elektrotechnische sector. Figuur I.6 laat zien dat de groei van de export in de basismetaal na een groei in 
2004 in 2005 is gestagneerd. Hetzelfde geldt voor de elektrotechnische industrie. In de andere drie sectoren was er in 2005 sprake van een stijging van het exportaandeel. Het exportaandeel steeg in in 2004 en 2005 het hardst in de machine industrie. In 2005 was de stijging van het exportaandeel het grootst in de transportmiddelenindustrie. In de metaalproductenindustrie was er de laatste jaren sprake van een beperkte stijging van het exportaandeel van de omzet.

\section{Figuur 1.6}

Verandering in omzetvolume op de buitenlandse afzetmarkt naar bedrijfstak (in \%)

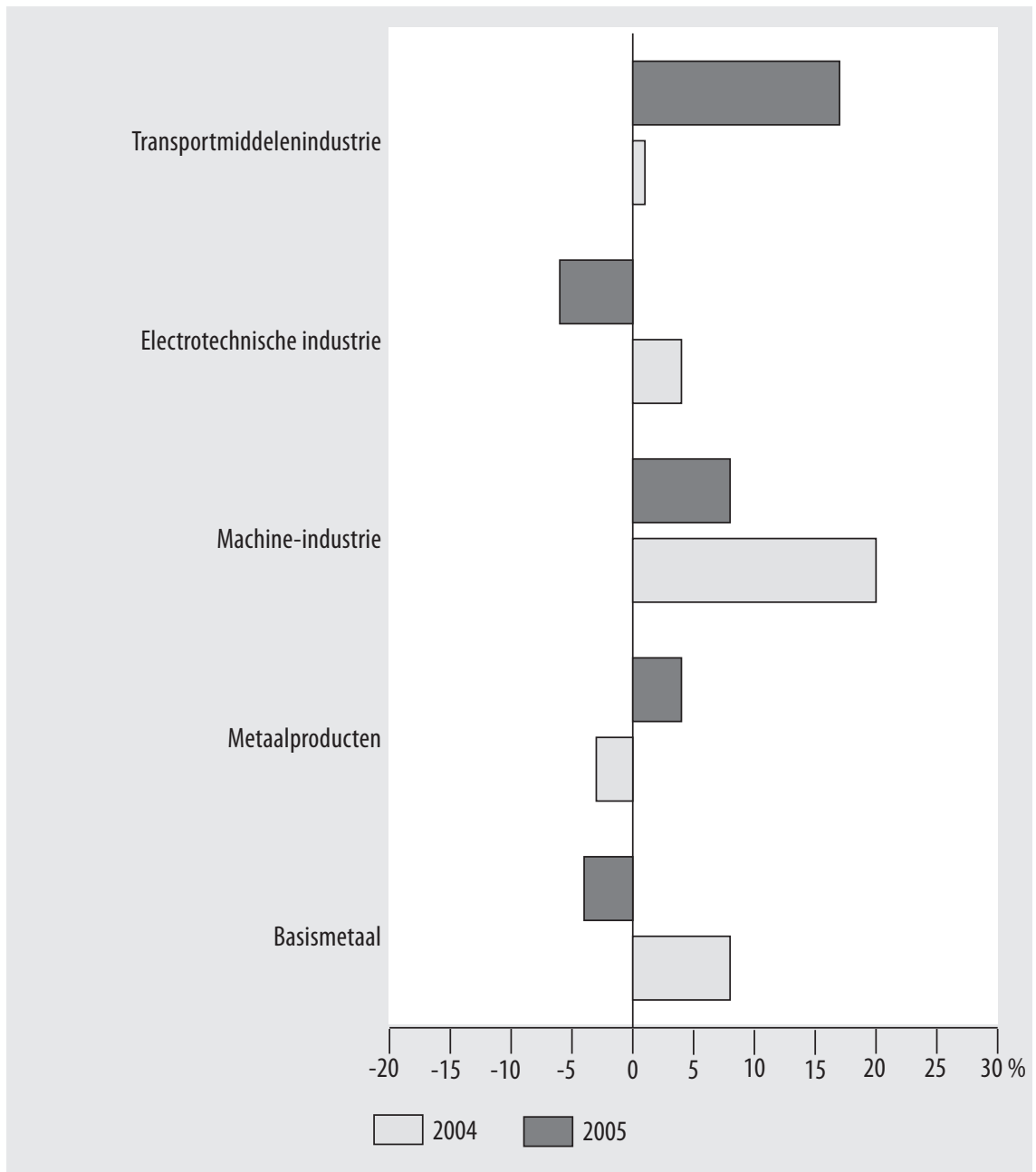

Bron: CBS

Naast de internationalisering van de afzetmarkten is er in de Nederlandse metaal en elektrotechnische sector ook sprake van een internationalisering van de bedrijfsac- 
tiviteiten. Zoals reeds eerder werd aangegeven, verwachten nogal wat bedrijven de komende jaren delen van hun productie aan buitenlandse $(44 \%)$ of binnenlandse (25\%) bedrijven uit te besteden.

\subsection{De Nederlandse Metalektro in Europees perspectief}

De grote dynamiek in de Nederlandse metalektrosector roept de vraag op hoe de Nederlandse Metalektro zich verhoudt tot de metalektrosectoren in de ons omringende landen. Zijn er belangrijke verschillen in productiviteit tussen de metalektrobedrijven in Nederland en de bedrijven in onze buurlanden? Hoe verhouden de investeringen van de Nederlandse metalektrobedrijven zich tot de investeringen in buitenlandse bedrijven? En zijn er opmerkelijke verschillen in de structuur van de werkgelegenheid? We kijken weer naar cijfers voor de gehele Nederlandse metaal en elektrotechnische sector.

\section{Figuur 1.7}

Arbeidsproductiviteit per sector, Nederland en omringende landen, 2002 (in €1.000)

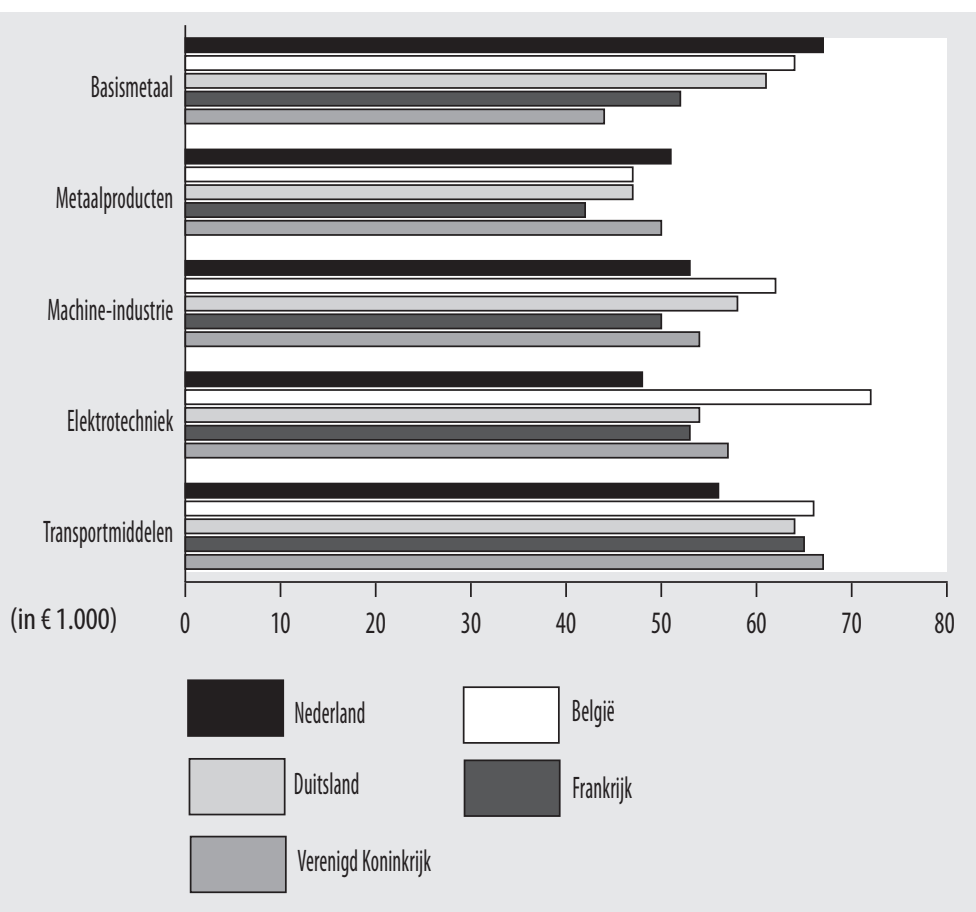

Bron: Eurostat, 2006

Hoe verhoudt de productiviteit van de Nederlandse metaal en elektrotechnische sector zich tot die van de buurlanden? In figuur I.7 kijken we naar de toegevoegde waarde per 
werknemer in Nederland en de omringende landen. De cijfers hebben betrekking op het jaar 2002. Dit zijn de meest recente cijfers die momenteel beschikbaar zijn.

Nederland blijkt erg goed te presteren in de basismetaal en in de sector metaalproducten. De productiviteit is hier het grootst. In de machine-industrie is België echter de koploper. De productiviteit per werknemer is in die sector in België bijna €ı૦.00० per werknemer hoger dan in Nederland. Ook in de elektrotechniek en in de transportmiddelensector scoort België erg goed. In deze sectoren loopt Nederland qua productiviteit wat achter.

Hoe innovatief is de Nederlandse metaal en elektrotechnische sector in vergelijking met het buitenland? Om hier enig inzicht in te krijgen kijken we in figuur I.8 naar de totale investeringen per werknemer in de verschillende sectoren van de metaal en elektrotechnische sector. Het blijkt dat de investeringen in de Nederlandse metaal en elektrotechnische sector wat achterlopen bij de investeringen in de metaal en elektrotechnische industrie van de ons omringende landen. Zo is er in de Belgische basismetaal bijna twee keer zoveel geïnvesteerd dan in de Nederlandse en investeren de Franse transportmiddelenbedrijven gemiddeld $€ \mathrm{I} 6.000$ per werknemer, terwijl de Nederlandse transportmiddelenindustrie slechts $€ 3.000$ per medewerker investeert. Ook in de elektrotechniek lopen de investeringen in Nederland wat achter bij die in de ons omringende landen.

\section{Figuur 1.8}

Investeringen per sector, Nederland en omringende landen, 2002 (in €1.000 per werknemer)

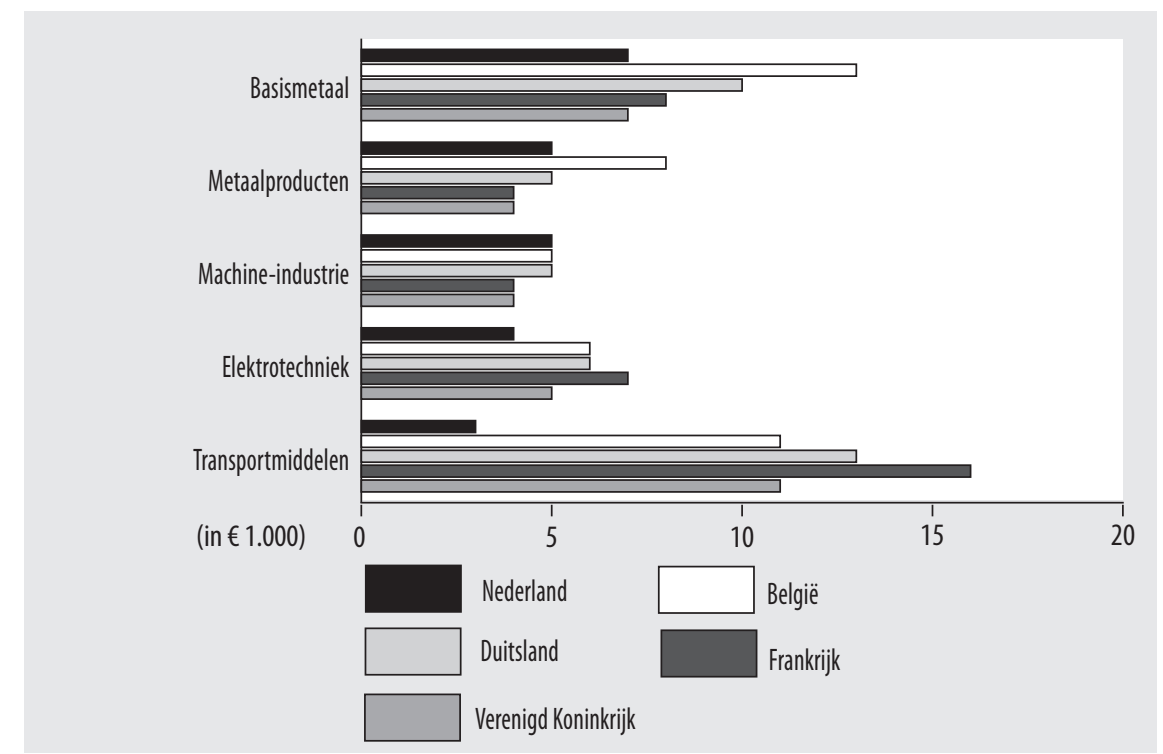

Bron: Eurostat, 2006 
Zijn er verschillen in de structuur van de werkgelegenheid tussen de Nederlandse metaal en elektrotechnische sector en de metaal en elektrotechnische industrie in de ons omringende landen? Figuur I.9 geeft een overzicht van drie werkgelegenheidskenmerken voor Nederland en de ons omringende landen België, Duitsland, Frankrijk en het Verenigd Koninkrijk. Het gaat om:

- het percentage mannen in de werkgelegenheid

- het percentage werknemers dat fulltime werkt

- het percentage werknemers dat ouder dan 50 jaar is.

\section{Figuur 1.9}

Werkgelegenheid naar sector, Nederland en omringende landen, 2004 (\% werknemers)



\section{Bron: Eurostat, 2006}

Het valt op dat er in de Nederlandse metaal en elektrotechnische sector relatief veel mannen werkzaam zijn. In alle sectoren is het aandeel van mannen in de werkgelegenheid in Nederland het hoogst. In de elektrotechniek is het verschil met de ons omringende landen het grootst. Terwijl in de ons omringende landen circa $70 \%$ van 
de werknemers man is, bedraagt het aandeel van mannen in de Nederlandse metaal en elektrotechnische sector meer dan $80 \%$. Het relatief geringe aantal vrouwen dat de Nederlandse metaal en elektrotechnische industrie werft, kan als gevolg hebben dat de Nederlandse metaal en elektrotechnische sector met grotere recruteringsproblemen zal worden geconfronteerd dan de ons omringende landen, waar meer vrouwen worden aangetrokken. De figuur laat ook zien dat er in de Nederlandse metaal en elektrotechnische sector relatief veel part-time (minder dan 35 uur per week) gewerkt wordt: In de meeste sectoren is het aandeel van het full-time personeel in Nederland vrij laag in vergelijking met de ons omringende landen. Mogelijk wordt het grote aandeel van part-timers gedeeltelijk veroorzaakt doordat er in Nederlandse bedrijven relatief veel in volcontinu dienst gewerkt wordt, maar het verschil met andere landen is dermate groot dat het toch opmerkelijk is te noemen, gezien het relatief geringe percentage vrouwen dat in de Nederlandse metalelektrobedrijven werkzaam is. Als laatste wordt er gekeken naar het aandeel van $50+$ ers in de werkgelegenheid. Het blijkt dat de vergrijzing in de Nederlandse metaal- en elektrotechnische industrie relatief laag is in vergelijking met de ons omringende landen, maar dat er wel aanzienlijke verschillen tussen sectoren bestaan. Zo is de vergrijzing, net als in de ons omringende landen, het sterkst in de basismetaal en de metaalproducten. De elektrotechniek heeft daarentegen het minste te maken met vergrijzing. In de sector elektrotechniek en de transportmiddelenindustrie is het werkgelegenheidsaandeel van de $50+$ ers in België echter nog lager dan in Nederland. In Duitsland is de vergrijzing over de gehele linie hoog. Het verschil met Nederland is ook groot, met name in de basismetaal, de metaalproductenindustrie en de machine industrie. In de machine industrie bedraagt het aandeel $50+$ ers in de werkgelegenheid in Nederland minder dan $20 \%$. In Duitsland is daarentegen ruim $30 \%$ van de werknemers in deze sector 50 jaar of ouder. 



\section{Arbeidsmarktontwikkelingen}

"We hebben steeds minder behoefte aan lager opgeleid personeel doordat onze productie al grotendeels in het buitenland zit."

"Onze Nederlandse vestiging draait steeds meer op hoogopgeleide technici, omdat ons bedrijf zich steeds meer ontwikkelt tot internationaal kenniscentrum".

"We kijken steeds kritischer of banen van vertrekkend personeel in de lagere functies nog wel moeten worden opgevuld."

"Mensen die met de VUT gaan worden bij ons in het algemeen niet meer vervangen."

"We voegen bepaalde functies samen om meer te kunnen realiseren met minder mensen".

"Het belang van een goed verkoopapparaat neemt toe. Vroeger kreeg je de klanten op een presenteerblaadje, maar tegenwoordig moet er heel wat werk verzet worden om klanten te behouden of nieuwe klanten te werven."

"We lenen vooral personeel in om pieken in de bedrijfsdrukte op te vangen, maar het is de bedoeling om de beste uitzendkrachten uiteindelijk zelf in dienst te nemen. We proberen die mensen een tijdje uit, en als ze goed bevallen dan nemen we ze in vaste dienst".

De bovenstaande citaten weerspiegelen de grote dynamiek op de arbeidsmarkt. Dat werpt de vraag op hoe de arbeidsmarkt in de Metalektro zich ontwikkelt. We kijken in dit hoofdstuk eerst naar de ontwikkelingen in de totale werkgelegenheid in de metaal en elektrotechnische industrie en de upgradingstendens van de afgelopen jaren. Vervolgens gaan we meer gedetailleerd in op de totale instroom van personeel, de personeelsuitstroom en de arbeidsmarktdynamiek in de periode 2002-2005. Daarna bekijken we de ontwikkelingen in 2005 voor een aantal verschillende functiecategorieën. Naast de in-en uitstroom van personeel komt daarbij ook aan de orde in hoeverre de bedrijven te maken hebben een met krimpende werkgelegenheid. Ten slotte zal worden aangegeven in welke mate bedrijven personeel inlenen, om welke soort functies het daarbij vooral gaat en waarom ze dat doen. 


\subsection{De werkgelegenheidsontwikkelingen van de afgelopen jaren}

De metaal en elektrotechnische industrie is een sector waarin de werkgelegenheid de laatste jaren krimpt. Door nieuwe productietechnieken en organisatorische innovaties kan er steeds meer gemaakt worden met steeds minder mensen. Daarnaast is er ook sprake van outsourcing van productiewerkzaamheden naar landen met een lager loonniveau.

Figuur 2.I geeft een overzicht van de ontwikkeling van de totale werkgelegenheid in de afgelopen jaren. Het gaat hier om het totaal aantal werkenden dat in de metaal en elektrotechnische industrie aan de slag is. In de jaren 1996-200I was de werkgelegenheid vrij stabiel, maar vanaf het jaar 200 I begint de werkgelegenheid behoorlijk te dalen. Tussen 200 I en 2004 ging er bijna een kwart van de totale werkgelegenheid in de metaal en elektrotechnische industrie verloren.

Figuur 2.1

Ontwikkeling van het aantal werkenden in de metaal en elektrotechnische industrie, 1996-2004 (in 1.000 werknemers)

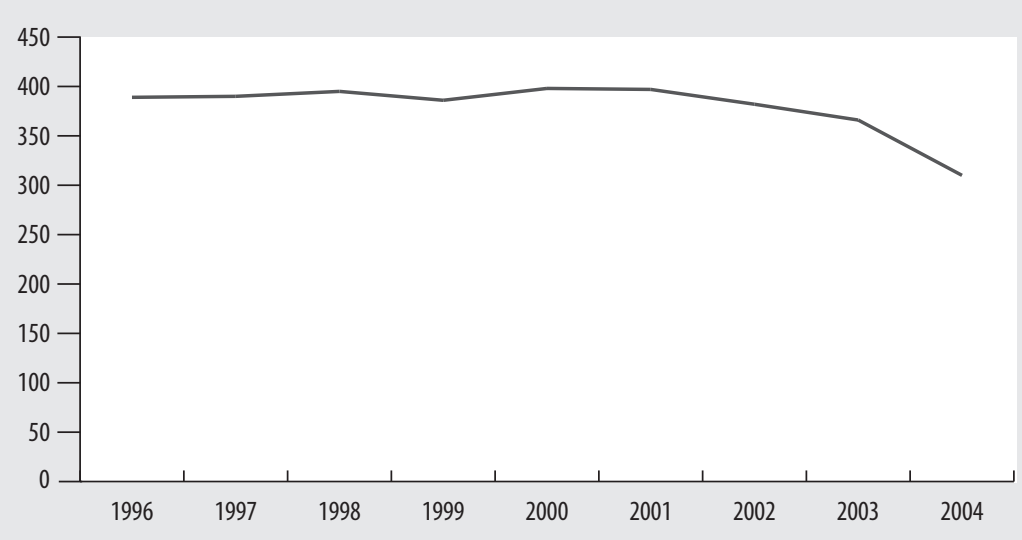

Bron: CBS

De daling van de werkgelegenheid roept ook de vraag op of de structuur van de werkgelegenheid is veranderd. Figuur 2.2 geeft een overzicht van de werkgelegenheid naar opleidingsniveau. Er wordt daarbij onderscheid gemaakt tussen laagopgeleid, middelbaar opgeleid (MBO) en hoogopgeleid (HBO en WO) personeel.

De figuur laat zien dat er vanaf 1996 sprake is van een veranderend personeelsbestand in de metaal en elektrotechnische industrie. Het werkgelegenheidsaandeel van laagopgeleide werknemers is tussen 1996 en 2004 gedaald met ruim 5\%-punten. In dezelfde periode steeg het werkgelegenheidsaandeel van hoogopgeleiden met ruim $4 \%$-punten. Uit gesprekken met de metalektrobedrijven blijkt dat veel bedrijven verwachten dat deze upgradingstrend zich ook de komende jaren zal doorzetten. De 
eisen die bedrijven aan hun personeel stellen worden steeds zwaarder, en dat vertaalt zich in een grotere vraag naar hoogopgeleid personeel.

Figuur 2.2

Samenstelling van de werkgelegenheid in de metaal en elektrotechnische industrie in ruime zin, 1996-2004

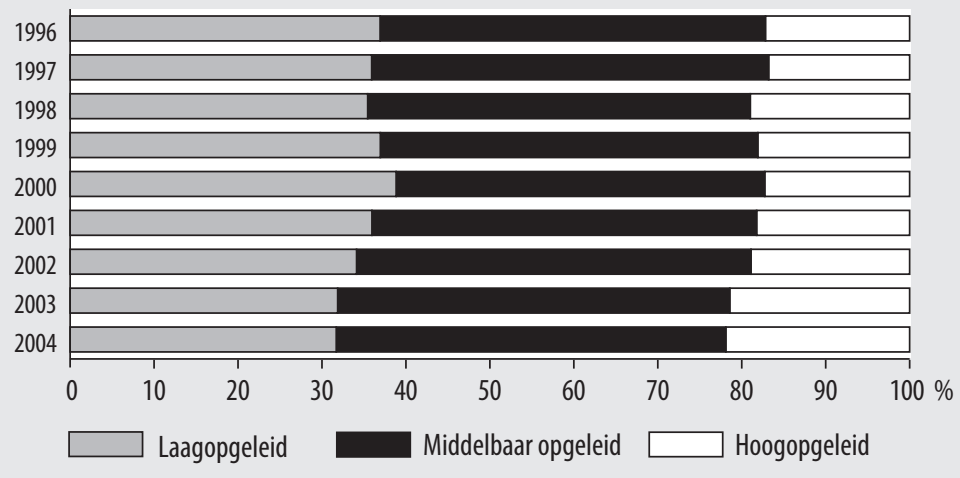

Bron: CBS

HRM-managers in de metalektrobedrijven bevestigen de upgradingstendens van de afgelopen jaren niet alleen, maar hebben er ook verklaringen voor. Een personeelsmanager aan het woord: "We hebben steeds minder behoefte aan lager opgeleid personeel doordat onze productie al grotendeels in het buitenland zit. Onze Nederlandse vestiging draait steeds meer op hoogopgeleide technici, omdat ons bedrijf zich steeds meer ontwikkelt tot internationaal kenniscentrum”. Een ander bedrijf zegt steeds kritischer te kijken of banen van vertrekkend personeel in de lagere functies nog wel moeten worden opgevuld: "We nemen nog maar sporadisch laagopgeleide technici aan, terwijl het nog wel regelmatig voorkomt dat we hoger opgeleid verkooppersoneel in dienst nemen".

\subsection{Instroom, uitstroom en werkgelegenheid in de periode 2002-2005}

Figuur 2.3 geeft een overzicht van de instroom en uitstroom van personeel en de werkgelegenheidsontwikkeling. Daarnaast wordt de arbeidsdynamiek in de Metalektro in het algemeen in beeld gebracht. In bijna de hele periode 2002-2005 lag het niveau van de instroom onder het niveau van de uitstroom, wat betekent dat de werkgelegenheid steeds verder afneemt. Het blijkt wel dat de daling van de werkgelegenheid wat afvlakt. In 2002 en 2003 was de krimp groter dan in de jaren 2004 en 2005.

Uit de figuur blijkt ook dat zowel de personeelsinstroom als de personeelsuitstroom in de periode 2002-2005 gedaald zijn. Dat betekent dat de totale arbeidsdynamiek kleiner is geworden: Steeds minder nieuwe werknemers gaan in een metalektrobedrijf 
werken en steeds minder werknemers verlaten de metalektrobedrijven. De daling van de instroom van nieuw personeel is voor een deel toe te schrijven aan de ongunstige conjuncturele ontwikkeling van de afgelopen jaren. Daarnaast is er in de Metalektro echter ook sprake van een structurele krimp. De conjuncturele neergang van de afgelopen jaren is wellicht ook verantwoordelijk voor de dalende uitstroom. Omdat werknemers in een laagconjunctuur minder mogelijkheden hebben om in een ander bedrijf werk te vinden zullen ze minder snel werk gaan zoeken in een ander bedrijf. Overigens is het wel te verwachten dat de uitstroom de komende jaren weer gaat stijgen, doordat relatief veel oudere werknemers door pensionering de Metalektro zullen gaan verlaten.

Figuur 2.3

Totale instroom, uitstroom, werkgelegenheidsontwikkeling en arbeidsmarktdynamiek in de Metalektro, 2002-2005, per halfjaarlijkse periode

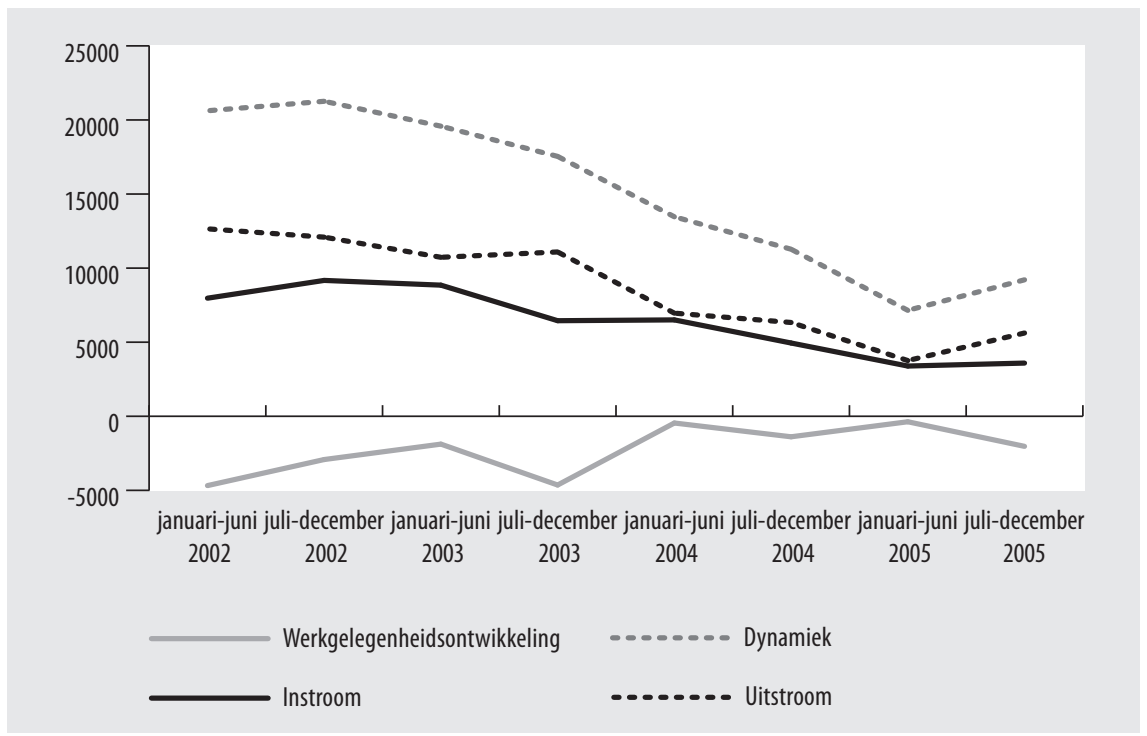

Bron: ROA/Werkgeverspanel Metalektro 2002-2005

\subsection{Instroom van nieuwe werknemers in 2005}

Hoeveel werknemers gingen er in 2005 in de Metalektro aan het werk en om welke functies ging het daarbij vooral? Figuur 2.4 geeft een overzicht van de instroom per functiecategorie. Zoals dat ook in eerdere jaren het geval was is de instroom van nieuwe werknemers in de uitvoerende technische functies het grootst. Ruim 3.500 uitvoerende technici gingen in 2005 bij een bedrijf in de Metalektro aan de slag. Op de tweede plaats komen de instromers met niet-technische ondersteunende functies. In 2005 aanvaardden circa I.200 werknemers een dergelijke functie. Er was in 2005 ook sprake van een aanzienlijke instroom van ondersteunende technici: Bijna I.০oo 
werknemers vonden in 2005 een baan in een dergelijke functie. Voor de overige functiecategorieën was de instroom in 2005 beperkter: 480 leidinggevende technici, 530 technisch opgeleide verkopers en 250 niet-technisch leidinggevenden.

\section{Figuur 2.4}

Aantal nieuwe werknemers in eerste en tweede helft van 2005, naar functiecategorie

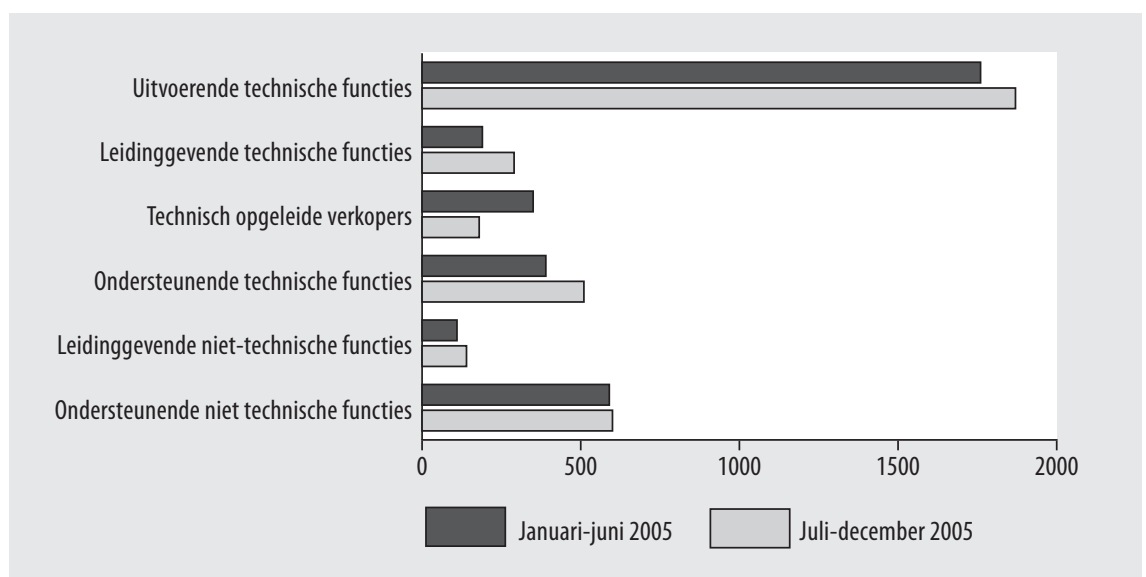

Bron: ROA/Werkgeverspanel Metalektro 2005

Er is echter wel een verschil in de personeelsinstroom tussen de eerste helft en de tweede helft van 2005. De instroom van uitvoerende, leidinggevende en ondersteunende technici en niet-technisch leidinggevenden is gedurende het jaar wat gestegen. Er was daarentegen sprake van een flinke daling van het aantal instromende technisch opgeleide verkopers. De instroom van niet-technische ondersteuners bleef gedurende het jaar gelijk.

\subsection{Personeelsuitstroom in 2005}

Hoeveel werknemers stroomden er in 2005 uit en om welke functies ging het daarbij vooral? Figuur 2.5 laat zien dat het grootste deel van de personeelsuitstroom in 2005 betrekking heeft op uitvoerende technici. Circa 4.500 uitvoerende technici verlieten de Metalektro in dat jaar.

In de andere functies is de uitstroom van personeel geringer. Zo vertrokken er in 2005 I.800 niet technische ondersteuners en $\mathrm{I} .450$ ondersteunende technici bij een metalektrobedrijf. Voor leidinggevende technici, niet-technisch leidinggevenden en technisch opgeleide verkopers bedroeg de personeelsuitstroom in 2005 respectievelijk 640,500 en 480 mensen. 


\section{Figuur 2.5}

Aantal vertrokken werknemers in eerste en tweede helft van 2005, naar functiecategorie

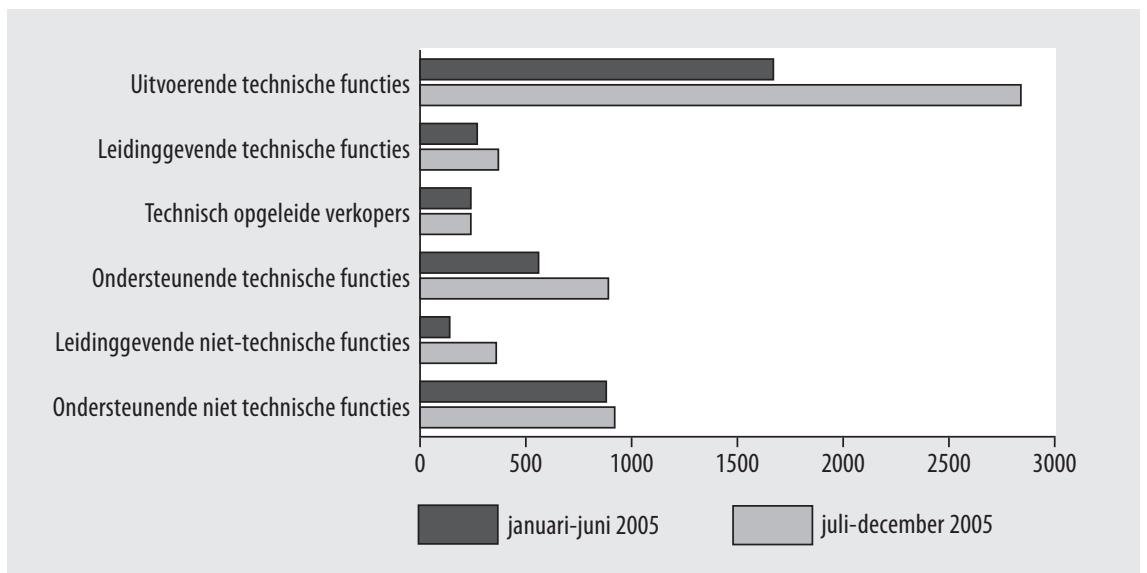

Bron: ROA/Werkgeverspanel Metalektro 2005

In de loop van 2005 is de uitstroom van personeel in bijna alle functiecategorieën gestegen. In de tweede helft van 2005 was de uitstroom van uitvoerende technici zelfs bijna het dubbele van de uitstroom in de eerste helft van het jaar. Deze toename van de uitstroom heeft waarschijnlijk verschillende oorzaken. Zo zullen meer werknemers het weer aandurven om op zoek te gaan naar een andere baan wanneer het in de Metalektro weer wat beter gaat. Ook heeft de groei van de uitstroom te maken met de vergrijzing van het personeelsbestand, waardoor meer werknemers als gevolg van pensionering de Metalektro verlaten.

\subsection{Krimpende werkgelegenheid in 2005}

Dat de uitstroom van personeel in 2005 groter is dan de instroom van nieuw personeel in de Metalektro betekent dat er sprake is van een krimpende werkgelegenheid. Figuur 2.6 geeft een overzicht van het aantal bedrijven dat in 2005 te maken had met een krimpende werkgelegenheid voor een bepaalde functiecategorie.

Het blijkt dat er bij meer dan een kwart van de bedrijven sprake is van krimpende werkgelegenheid voor uitvoerend technisch personeel, terwijl er bij circa $20 \%$ van de bedrijven sprake is van een krimpende werkgelegenheid voor ondersteunend niettechnisch personeel. In 2004 gaf nog circa een derde van de bedrijven aan dat er sprake was van een werkgelegenheidskrimp voor uitvoerend technisch personeel. Dit betekent dat het voorzichtige herstel van de conjunctuur in 2005 zich ook vertaalt in minder krimp voor uitvoerende technici. Uit de interviews met bedrijven die aan het werkgeverspanel deelnemen blijkt dat die bedrijven waarin de werkgelegenheid voor het uitvoerend technisch personeel nog wel krimpt, dit een aantal verschillende oorzaken heeft. Allereerst is de krimp vaak het gevolg van een vergrijsd personeelsbe- 
stand. Volgens een personeelsfunctionaris worden mensen die met de VUT gaan in het algemeen niet meer vervangen. Bij andere bedrijven worden er functies samengevoegd, om "meer te kunnen realiseren met minder mensen".

\section{Figuur 2.6}

Krimpende werkgelegenheid naar functiecategorie, 2005 (\% bedrijven)

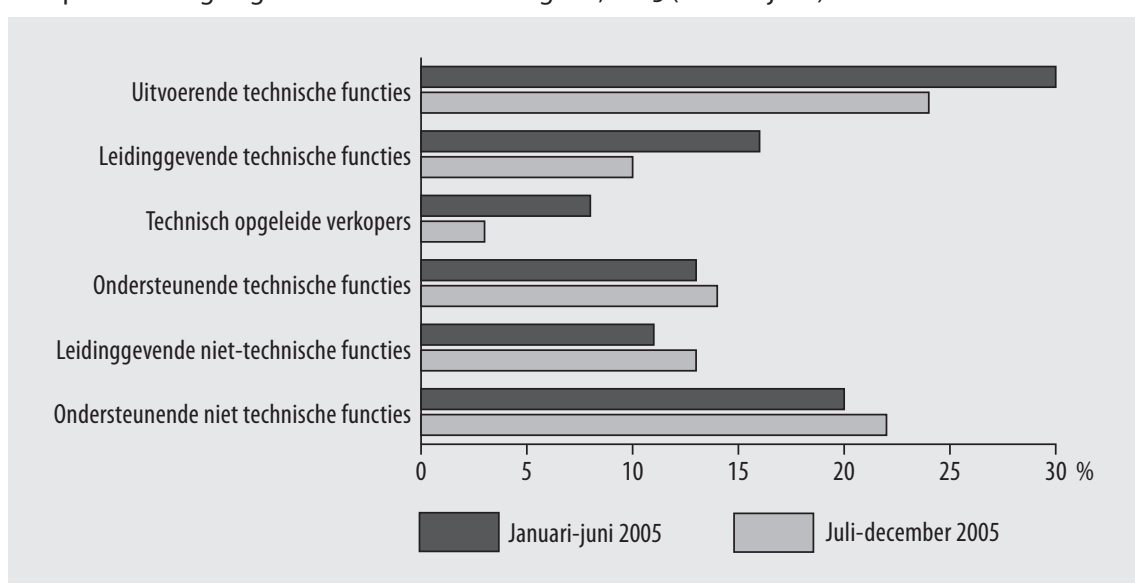

Bron: ROA/Werkgeverspanel Metalektro 2005

Het is opvallend dat het aantal bedrijven met een krimpende werkgelegenheid voor uitvoerend technisch personeel, leidinggevend technisch personeel en technisch opgeleide verkopers in de loop van 2005 is afgenomen. Het aantal bedrijven met een krimpende werkgelegenheid voor ondersteunende technici, niet-technisch leidinggevenden en werknemers met ondersteunende niet-technische functies is daarentegen toegenomen. Dat het aantal bedrijven met krimpende werkgelegenheid voor technisch opgeleide verkopers in de loop van 2005 flink is afgenomen heeft volgens de bedrijven zelf te maken met het toenemende belang van het verkoopapparaat: "Er moet meer werk geleverd worden om goed te blijven verkopen dan in het verleden. Vroeger kreeg je de klanten op een presenteerblaadje omdat ze zelf naar je toe kwamen; tegenwoordig moeten klanten vanwege de grotere concurrentie veel actiever benaderd worden”.

\subsection{Personeel inlenen}

De metalektrobedrijven kunnen ook in hun personeelsbehoefte voorzien door gebruik te maken van personeel in dienst is van een bedrijf dat niet tot de metalektrosector behoort. Het gaat dan om uitzendkrachten, ingeleend personeel of gedetacheerde werknemers. Hoeveel mensen werden er in 2005 in de Metalektro ingeleend en om welke functies ging het daarbij vooral? 
Figuur 2.7 laat zien dat er in de metalektrobedrijven in 2005 ruim 10.000 uitvoerende technici werden ingeleend. Op de tweede plaats qua omvang komen ondersteunende technici en het niet-technisch ondersteunend personeel. Leidinggevende technici, technisch opgeleide verkopers en niet-technisch leidinggevenden worden zelden ingeleend.

\section{Figuur 2.7}

Aantal ingeleende werknemers naar beroepscategorie, 2005

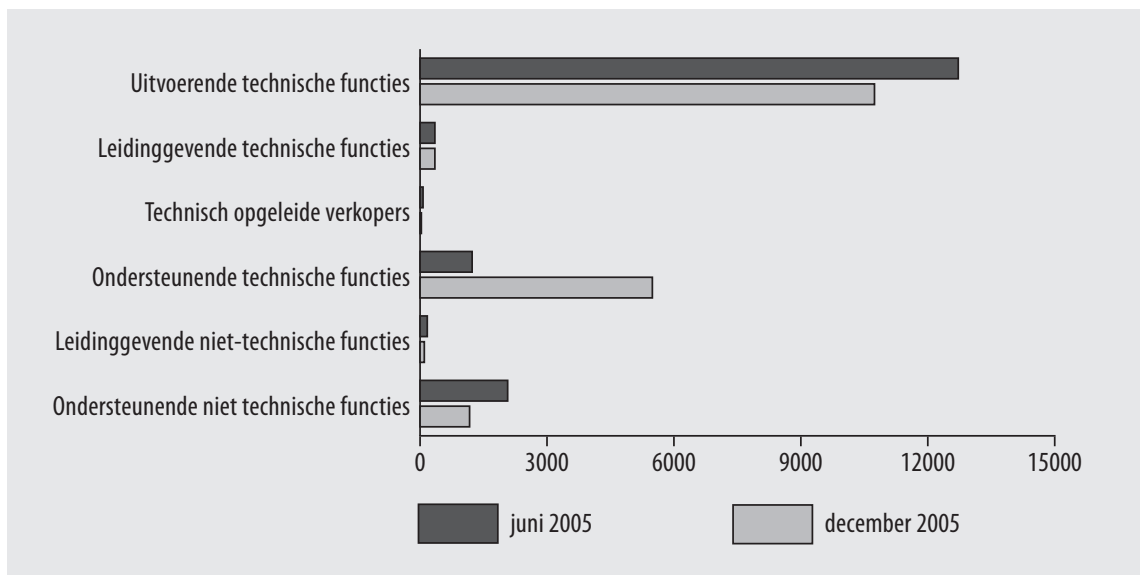

Bron: ROA/Werkgeverspanel Metalektro 2005

Gedurende 2005 is het totaal aantal mensen dat is ingeleend toegenomen van circa I6.500 tot bijna I8.000. Figuur 2.7 laat zien dat deze toename vooral betrekking had op ondersteunende technici. Daarentegen daalde het aantal ingeleende uitvoerende technici en niet-technische ondersteuners.

Uit gesprekken met metalektrobedrijven blijkt dat bedrijven vaak personeel inlenen om pieken in de bedrijfsdrukte op te vangen. Maar veel bedrijven lenen ook personeel in met de bedoeling om de beste uitzendkrachten uiteindelijk zelf in dienst te nemen. Een HRM-manager omschrijft het als volgt: "We proberen die mensen een tijdje uit. Als ze goed bevallen dan worden ze, nadat ze een tijd via een uitzendbureau als flexibele kracht bij ons hebben gewerkt, bij ons in vaste dienst genomen". Toch lenen niet alle metalektrobedrijven personeel in. Een personeelsmanager: We werven via de klassieke kanalen en dat gaat erg goed. We hebben al zeven jaar geen uitzendkrachten meer in dienst gehad". 


\section{De werving van nieuw personeel}

"We hebben helemaal geen behoefte aan personeelsverloop, nieuwe kennis en vaardigheden kun je ook prima in je eigen personeelsbestand ontwikkelen.”

"Een paar jaar geleden hadden we grote problemen met het vinden van geschikt personeel, en ik vrees dat dat scenario zich de komende jaren zal herhalen."

"We groeien behoorlijk, er is vraag naar allerlei soorten personeel."

"Bij ons zullen de wervingsproblemen alleen maar gaan toenemen, doordat we in een sterk vergrijsde regio zitten."

"Er zijn gewoon onvoldoende mensen met ervaring beschikbaar."

"We hebben geen problemen met het aantrekken van laag en ongeschoold personeel doordat er in Nederland veel laaggeschoold werk verdwijnt en er dus best genoeg aanbod van dat soort mensen blijft bestaan."

"Onze wervingsproblemen ontstaan omdat we te veel eisen van de nieuwkomers."

"In de komende tijd zullen te hoge salariseisen weer een probleem worden bij het aantrekken van technici."

"Omdat we geen goed genoeg personeel kunnen vinden leiden we de mensen zelf op."

"De digitalisering van de arbeidsmarkt is onmiskenbaar."

"Mond-op-mond reclame is bij het werven van personeel erg effectief."

"We zoeken naar mensen die verder kijken dan hun huidige werk".

"Ons imago op de arbeidsmarkt is goed, we ondernemen geen speciale acties." 
"Het is echt nodig dat er een goed contact met de scholen bestaat, omdat die moeten zorgen voor het personeel dat we in de toekomst nodig hebben."

"Het lukt ons niet goed om hoogopgeleid personeel uit Duitsland aan te trekken."

"De Duitse en Poolse werknemers waren bereid tot vele uren inzet, hadden veel ervaring en waren erg gemotiveerd."

De uitspraken van metalektrobedrijven maken duidelijk dat het niet altijd even gemakkelijk is om geschikt personeel te vinden. In dit hoofdstuk gaan we in op de werving van nieuw personeel in de Metalektro. We beginnen met het verloop: Vinden bedrijven dat ze een hoog of juist een laag personeelsverloop hebben? Daarna kijken we naar de ontwikkeling van het aantal vacatures in de sector van de afgelopen jaren. Vervolgens kijken we naar het aantal vacatures per functiecategorie in 2005, hoelang die vacatures openstaan en waardoor ze zijn ontstaan. In het tweede gedeelte van het hoofdstuk gaan we in op problemen bij de werving van personeel en hoe bedrijven daarmee omgaan. Daarna kijken we naar het belang van verschillende wervingskanalen die de bedrijven gebruiken bij het aantrekken van nieuw personeel, op basis van welke competenties de bedrijven hun nieuwe personeel selecteren en welke rol het imago van het bedrijf speelt bij de werving. We sluiten af met werven in het buitenland: Om hoeveel werknemers gaat het, waar komen de werknemers vooral vandaan en warom werven sommige metalektrobedrijven in het buitenland? 


\subsection{Verloop van personeel}

De innovaties die de komende tijd zullen worden doorgevoerd vereisen dat bedrijven over voldoende personeel met de juiste kwalificaties beschikken. In dat kader is het van belang dat het verloop van het personeel niet te groot is, omdat er op die manier in het bedrijf opgebouwde kennis en vaardigheden verloren kunnen gaan. Aan de andere kant is het voor een bedrijf ook niet gezond als er helemaal geen verloop plaatsvindt. Het is immers goed als er af en toe mensen uitstromen die door nieuwe krachten worden vervangen. Dit geldt met name ook voor bedrijven waarvan de werkgelegenheid niet groeit. Ook voor deze bedrijven is het belangrijk dat ze de beschikking krijgen over nieuwe ideeën en kennis en vaardigheden. Toch blijkt dat niet alle bedrijven vinden dat een bepaald verloop noodzakelijk is. Een HRM-manager vindt "het idee dat je soms vers bloed nodig hebt" helemaal niet relevant voor haar bedrijf: "Nieuwe kennis en vaardigheden kun je ook prima in je eigen personeelsbestand ontwikkelen".

Wat vinden de bedrijven van hun personeelsverloop? En verwachten ze op dat vlak in de nabije toekomst veranderingen? Figuur 3.I laat duidelijk zien dat de overgrote meerderheid van de bedrijven vindt dat er erg weinig of geen personeelsverloop plaatsvindt. I2\% van de bedrijven vindt het verloop gemiddeld. Slechts een klein aantal bedrijven vindt dat er in hun bedrijf sprake is van veel (3\%) of erg veel (3\%) verloop.

Figuur 3.1

Personeelsverloop in 2005 ten opzichte van 2004 (\% bedrijven)

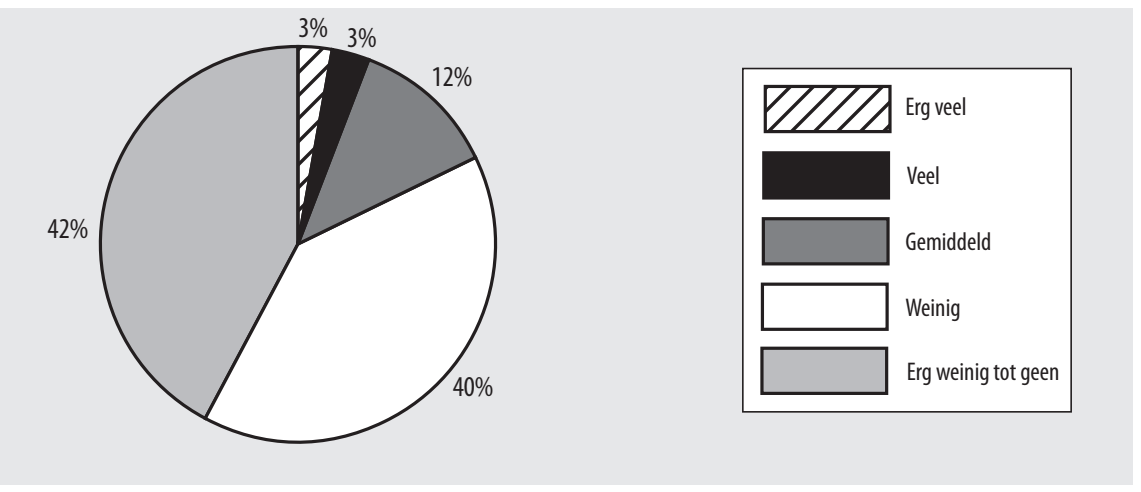

Bron: ROA/Werkgeverspanel Metalektro 2005

Verwachten de bedrijven dat hun personeelsverloop in de nabije toekomst zal toe- of juist zal afnemen? Figuur 3.2 laat zien dat de meeste bedrijven de komende jaren geen grote veranderingen in hun personeelsverloop verwachten. Maar weinig bedrijven verwachten dat het verloop (sterk) zal afnemen. Circa een kwart van de bedrijven verwacht daarentegen dat het verloop de komende vijf jaar (sterk) zal toenemen. Het blijkt dus dat het aantal bedrijven dat verwacht dat het personeelsverloop zal stijgen groter is dan het aantal bedrijven dat de komende jaren een dalend personeelsverloop 
verwacht. Dit kan wellicht verklaard worden uit het feit dat er in de komende jaren sprake zal zijn van een aanzienlijke uitstroom van personeel dat met pensioen gaat.

Figuur 3.2

Inschatting personeelsverloop in komende 5 jaar (\% bedrijven)

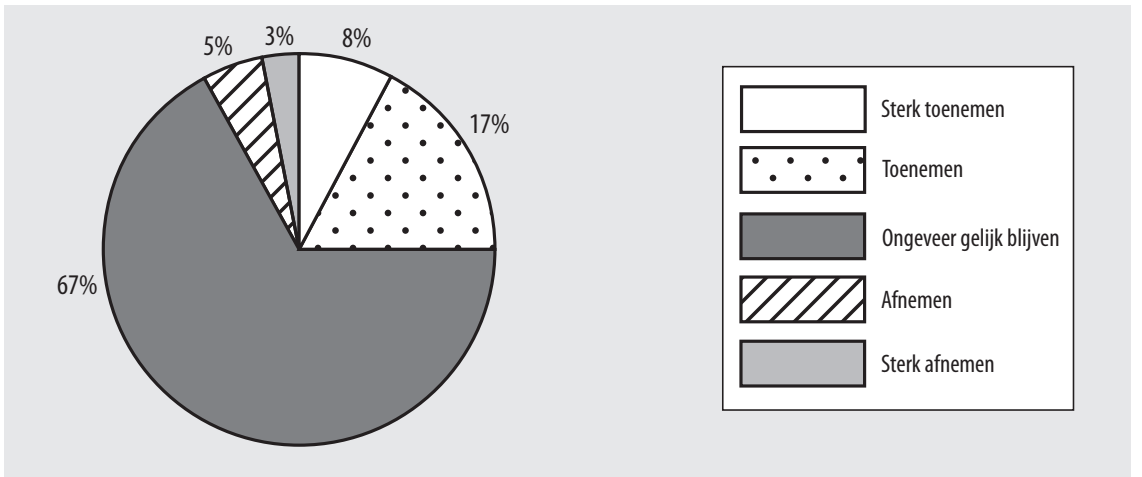

Bron: ROA/Werkgeverspanel Metalektro 2005

\subsection{Vacatures}

\section{De ontwikkelingen in de periode 2002-2005}

Figuur 3.3 geeft een overzicht van de ontwikkeling van het totale aantal vacatures in de Metalektro op basis van de verschillende metingen van het werkgeverspanel in de jaren 2002-2005. In de jaren 2002 en 2003 daalde het aantal vacatures van bijna 5.000 tot minder dan 2.000. Daarna steeg het aantal vacatures tot circa 4.000 in april 2004. Gedurende de rest van 2004 en de eerste helft van 2005 was er echter opnieuw sprake van een daling van het aantal vacatures. In juni 2005 stonden er nog circa 2.500 vacatures in de Metalektro open. In de tweede helft van 2005 steeg het aantal openstaande vacatures echter aanzienlijk. In december 2005 bedroeg het aantal vacatures in de Metalektro weer bijna 4.000. Deze stijging van het aantal vacatures weerspiegelt de verbeterde conjuncturele situatie.

Ook uit de interviews met metalektrobedrijven komt naar voren dat de bedrijven duidelijk merken dat de stand van de conjunctuur een grote invloed uitoefent op het aantal vacatures in de sector. Zo geven meerdere bedrijven aan dat het een aantal jaar geleden heel erg moeilijk was om mensen te vinden voor technische functies. Een personeelsmanager vreest dat die situatie zich in de nabije toekomst zou kunnen herhalen: "Er zullen veel vacatures zijn, terwijl het aanbod van geschikte kandidaten onvoldoende is". 
Figuur 3.3

Ontwikkeling van het totaal aantal vacatures in de Metalektro, 2002-2005

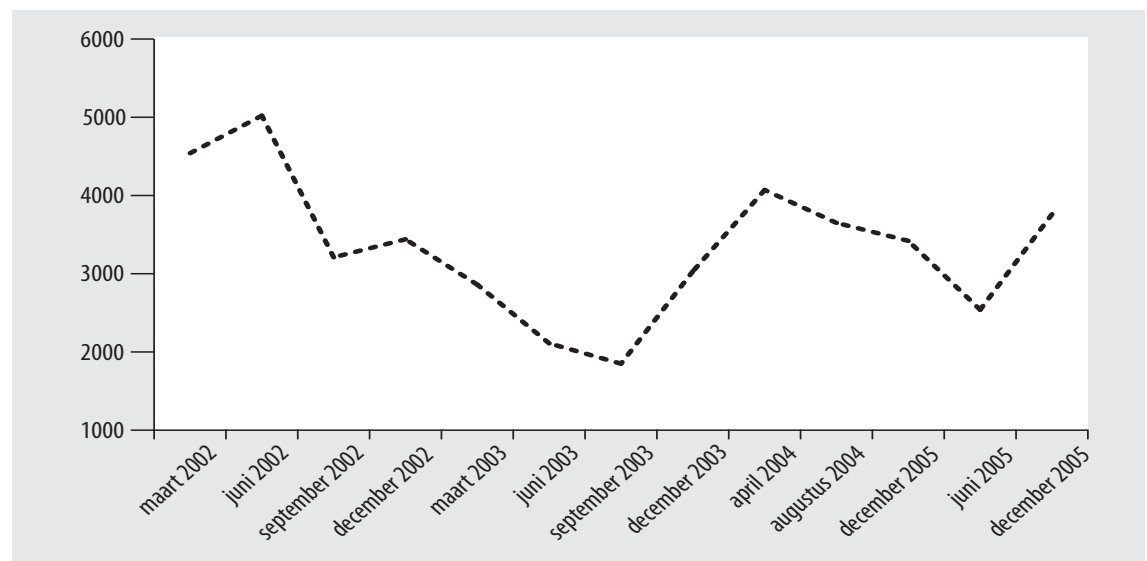

Bron: ROA/Werkgeverspanel Metalektro 2002-2005

\section{Aantal vacatures naar functiecategorie in 2005}

Voor welke soort functies hadden de bedrijven in de Metalektro in 2005 vacatures? Figuur 3.4 laat zien er in 2005 gemiddeld I.5OO vacatures voor uitvoerende technische functies openstonden. Voor ondersteunende technici stonden er in 2005 gemiddeld 600 vacatures open. Voor de andere functiecategorieën was het aantal openstaande vacatures veel kleiner: Circa 300 voor leidinggevende technici, 300 voor technisch opgeleide verkopers, 200 voor niet-technischondersteunend personeelen 9ovoorniet-technischleidinggevend personeel.

\section{Figuur 3.4}

Aantal openstaande vacatures per functiecategorie per half jaar, 2005

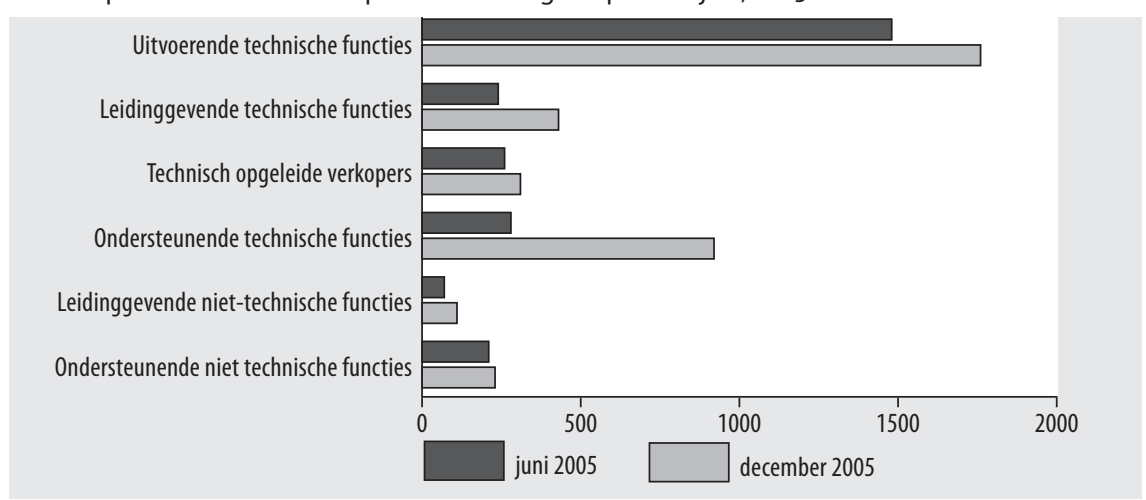

Bron: ROA/Werkgeverspanel Metalektro 2005 
Het is opvallend dat het aantal vacatures voor iedere functiecategorie in de loop van 2005 gestegen is. Vooral het aantal vacatures voor ondersteunende technische functies en leidinggevende technische functies nam aanzienlijk toe. Toch blijkt dat niet voor alle bedrijven te gelden. Een bedrijf dat sterk internationaal georiënteerd is, licht dat toe: "We zijn wel op zoek naar ondersteunende technici, maar niet voor onze Nederlandse vestiging. Ons ondersteunend personeel zit vooral in Azië”.

\section{Duur van openstaande vacatures}

Hoe lang staan de vacatures in de metalektrobedrijven gemiddeld open? Figuur 3.5 laat zien dat bijna $70 \%$ van de vacatures voor technisch personeel in juni 2005 minder dan drie maanden openstond. Circa $20 \%$ stond tussen de drie en zes maanden open en iets meer dan IO\% van de vacatures stond meer dan zes maanden open. Aan het eind van het jaar lijkt het voor de metalektrobedrijven weer wat gemakkelijker geworden om technisch personeel te werven. In december 2005 bedroeg het aandeel van vacatures dat korter dan drie maanden openstond ruim $80 \%$, terwijl ı०\% van de vacatures tussen de drie en zes maanden openstond. IO\% van het totale aantal vacatures stond langer dan zes maanden open. Dit betekent dat $20 \%$ van het totale aantal vacatures in de Metalektro gekarakteriseerd kan worden als moeilijk vervulbaar.

\section{Figuur 3.5}

Vacatures voor technisch personeel, naar het aantal maanden dat ze openstaan, 2005 (\% vacatures)

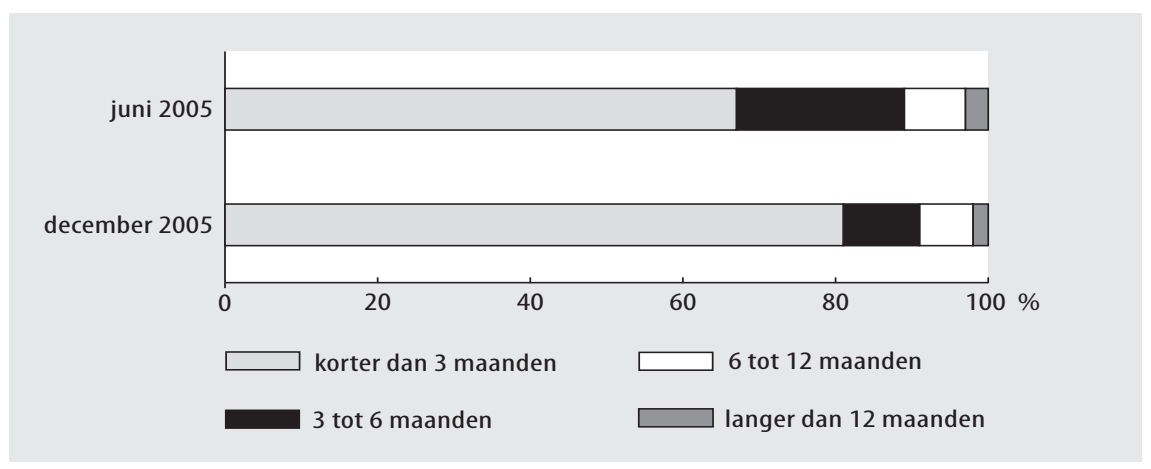

Bron: ROA/Werkgeverspanel Metalektro 2005

\section{Ontstaan van vacatures}

Waardoor zijn de vacatures in 2005 ontstaan? Figuur 3.6 laat zien dat de groei van het bedrijf en het vertrekken van personeel veruit de belangrijkste redenen zijn voor het ontstaan van vacatures. In $57 \%$ van de bedrijven ontstaan er vacatures door de toename van het werk. De personeelsmanager van een middelgroot bedrijf in de regio Zuid kan dit beamen: "we groeien behoorlijk, daarom is er steeds meer vraag naar allerlei soorten personeel”. 
Figuur 3.6

Vacatures voor technisch personeel naar reden van ontstaan, 2005 (\% bedrijven)

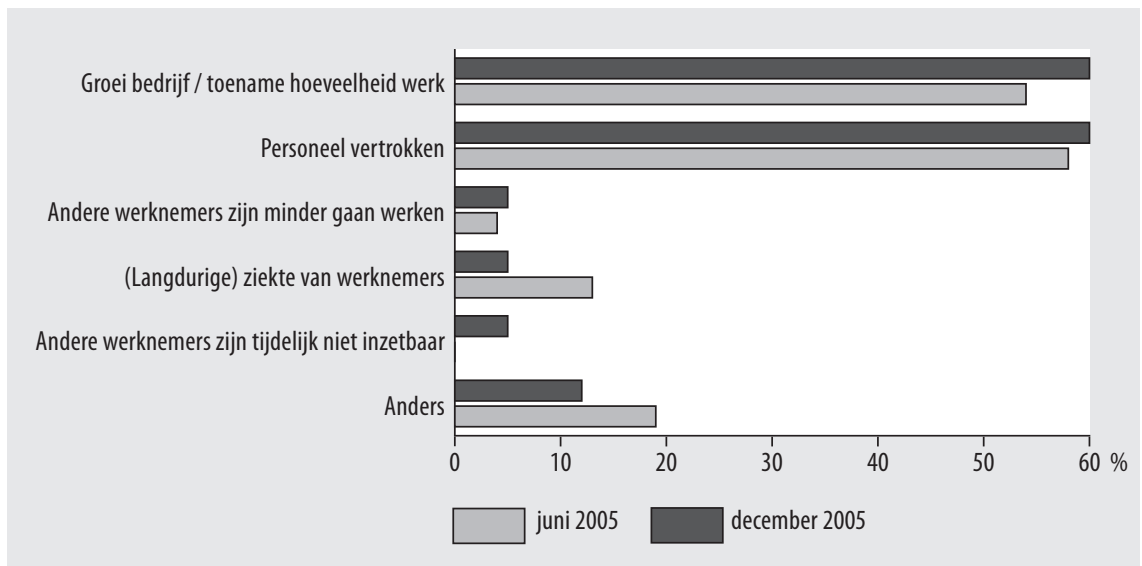

Bron: ROA/Werkgeverspanel Metalektro 2005

In maar liefst $60 \%$ van de bedrijven leidt het vertrek van personeel tot vacatures. Bij enkele bedrijven ontstaan vacatures doordat andere werknemers minder zijn gaan werken, door langdurige ziekte van werknemers of doordat andere werknemers tijdelijk niet inzetbaar zijn. Enkele andere redenen voor het ontstaan van vacatures zijn interne mobiliteit van personeel en veranderingen in de structuur van de organisatie.

\subsection{Problemen bij de werving van personeel}

Figuur 3.7 geeft voor de jaren 2002-2005 een overzicht van de mate waarin bedrijven bij de werving van technisch personeel problemen ondervinden. In de jaren 20022004 ondervonden de metalektrobedrijven steeds minder problemen bij het vinden van geschikt technisch personeel. In 2004 waren er dan ook vrijwel geen bedrijven meer die aangaven erg veel wervingsproblemen te ondervinden. In het recessiejaar 2004 vond zelfs meer dan de helft van de bedrijven dat het vinden van technisch personeel geen of slechts erg weinig problemen opleverde. In 2005 werd het werven van technisch personeel weer wat moeilijker. In dat jaar ondervond bijna $20 \%$ van de bedrijven weer veel problemen bij het vinden van technisch personeel, terwijl het aantal bedrijven dat helemaal geen of erg weinig problemen ondervindt bij de werving weer wat daalde. 
Figuur 3.7

Problemen bij het vinden van technisch personeel, 2002-2005 (\% bedrijven)

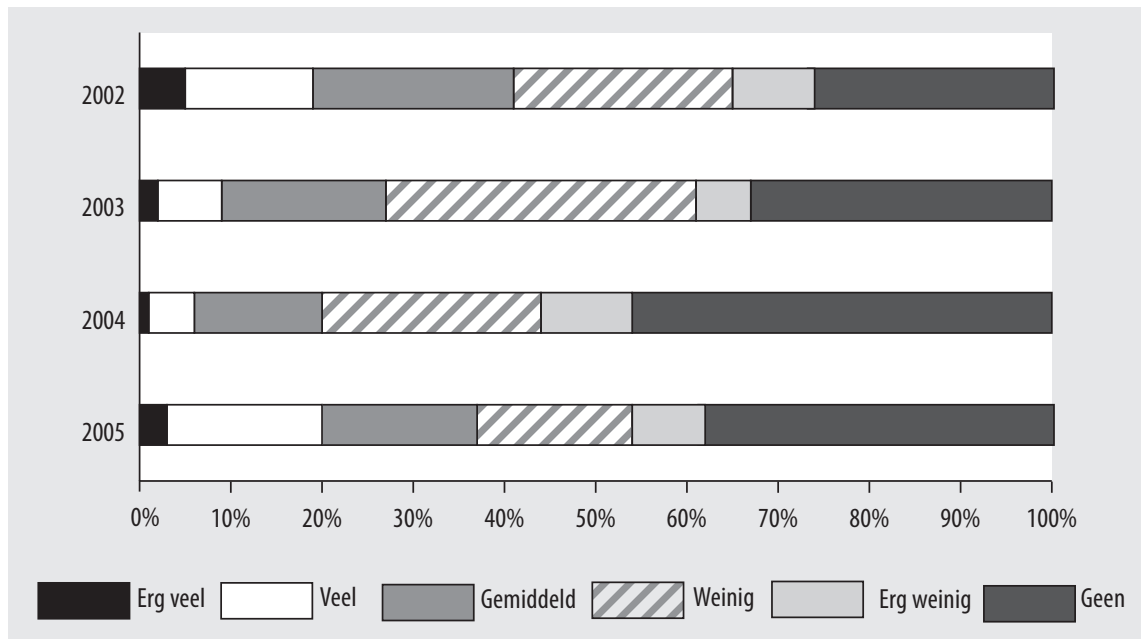

Bron: ROA/Werkgeverspanel Metalektro 2002-2005

Enkele uitspraken van personeelsmanagers in de sector illustreren de toegenomen wervingsproblemen in 2005. Een HRM-manager van een high-tech bedrijf vertelt dat er "momenteel gewoon onvoldoende mensen met ervaring beschikbaar zijn", terwijl een ander bedrijf steeds meer moeite krijgt met het vinden van internationale buitendienstmonteurs. Toch hebben niet alle metalektrobedrijven moeite bij het werven van technisch personeel. Een bedrijf met nog veel laaggeschoold werk denkt dat dit komt doordat er in Nederland steeds meer productiewerk verdwijnt en er daarom voldoende aanbod blijft van laag en ongeschoold personeel. Een ander bedrijf vindt dat de problemen bij de werving van nieuw personeel van voorbijgaande aard zijn: "We moeten wel eens een aantal maanden geduld hebben, maar uiteindelijk vinden we toch het personeel dat we nodig hebben".

Volgens een aantal bedrijven zullen de wervingsproblemen in de komende jaren gaan toenemen. Een personeelsfunctionaris: "In de toekomst zal het steeds lastiger worden om goed personeel aan te trekken, doordat de krapte op de arbeidsmarkt weer zal gaan toenemen". Een ander bedrijf denkt dat de vergrijzing van de beroepsbevolking ook meespeelt: "De wervingsproblemen zullen toenemen, zeker doordat we in een regio zitten waarin de vergrijzing sowieso sterker is dan in de rest van het land". Een derde bedrijf constateert een verbreding van de wervingsproblemen: "Een tijd geleden was het vooral moeilijk om middelbaar en hoger technisch opgeleid personeel te vinden. Sinds een paar maanden lijkt het over de volle breedte steeds moeilijker te worden. We hebben zelfs moeite om een vacature voor een administratief medewerker te vervullen". 
Met welke problemen krijgen de metalektrobedrijven vooral te maken wanneer ze proberen om technisch personeel te werven? Figuur 3.8 geeft een overzicht van de problemen die bedrijven in de periode 2002-2005 het vaakst noemen. Het grootste probleem bij het vervullen van openstaande vacatures was dat er te weinig aanbod was van sollicitanten met de juiste competenties. Meer dan driekwart van de bedrijven die wervingsproblemen ondervonden gaf aan dat een tekortschietend aanbod van mensen met de juiste kennis en vaardigheden het vervullen van openstaande vacatures bemoeilijkt. Een bedrijf uit de machine industrie denkt dat de wervingsproblemen ook ontstaan doordat het bedrijf te veel van de nieuwkomers eist: "Onze buitendienstmonteurs moeten niet alleen over een goede vakkennis beschikken maar ook nog multidisciplinair kunnen werken in een internationale context”.

\section{Figuur 3.8}

Belangrijkste problemen bij het vervullen van openstaande vacatures voor technisch personeel, 2002-2005 (in \% van de bedrijven met wervingsproblemen)

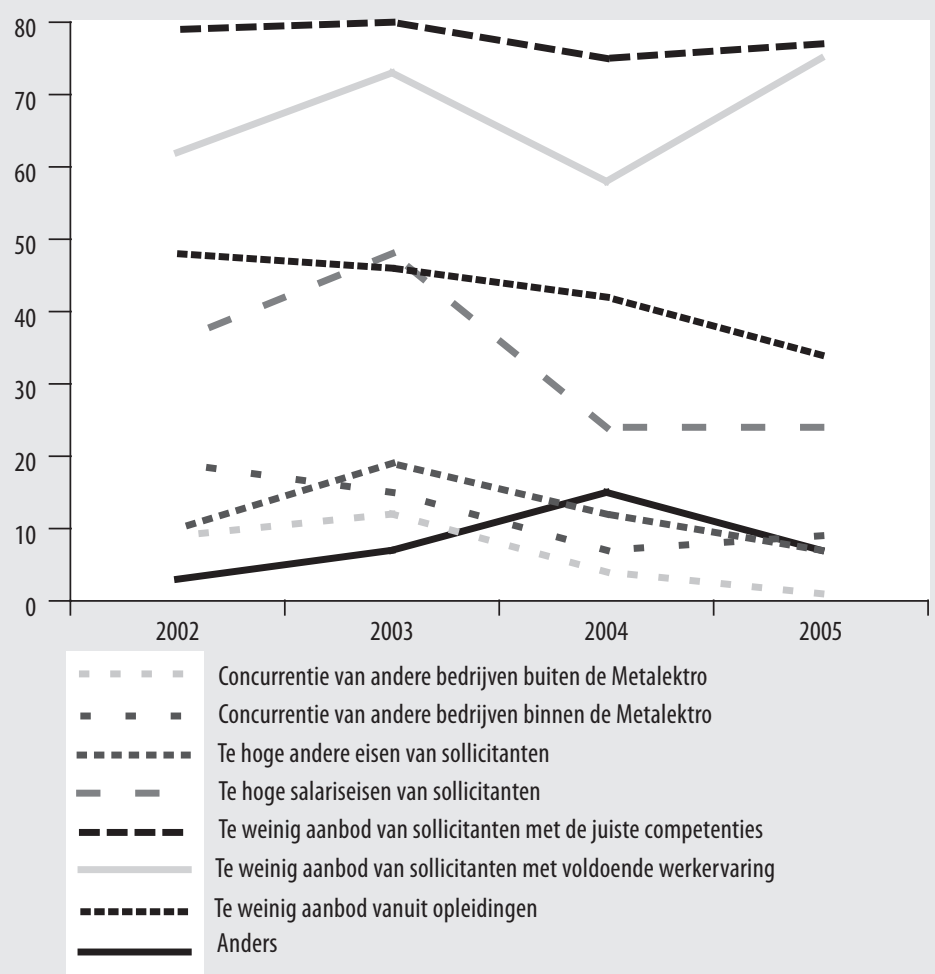

Bron: ROA/Werkgeverspanel Metalektro 2002-2005

Een tweede belangrijk probleem was dat er te weinig sollicitanten beschikbaar waren met voldoende werkervaring. In 2004 had bijna 60\% van de bedrijven hiermee te kampen. In 2005 is het probleem nog groter geworden: Bijna driekwart van de 
bedrijven met wervingsproblemen had in dat jaar moeite met het vervullen van openstaande vacatures door een tekort van sollicitanten met werkervaring. Een uitspraak van de personeelsfunctionaris van een high-tech bedrijf illustreert dat werkervaring vaak cruciaal is: "we kunnen onze bedrijfsdoelstellingen niet goed realiseren zonder voldoende personeel dat over een goede werkervaring beschikt".

Een derde probleem bij het vervullen van openstaande vacatures is dat er te weinig aanbod is van schoolverlaters. Het valt wel op dat dit probleem steeds minder vaak wordt genoemd. In 2002 vond nog bijna de helft van de bedrijven dat het aanbod vanuit de opleidingen tekortschoot, terwijl in 2005 nog slechts een derde van de metalektrobedrijven met wervingsproblemen voor technisch personeel vond dat dat het gevolg was van een te beperkt aanbod van schoolverlaters. Deze daling wordt waarschijnlijk mede veroorzaakt door het feit dat de metalektrobedrijven steeds meer waarde zijn gaan hechten aan werkervaring. Toch zijn er ook bedrijven die het tekortschietend aanbod van schoolverlaters wel zien als een belangrijk probleem. Dit blijkt vaak samen te hangen met de regio waarin het bedrijf actief is. Twee metalektrobedrijven waarmee interviews zijn gehouden gaven aan dat ze in een regio zitten waarin het aanbod van schoolverlaters met de juiste opleiding erg gering is.

Een kwart van de bedrijven met wervingsproblemen vindt dat de problemen bij het vervullen van openstaande vacatures optreden omdat sollicitanten te hoge salariseisen stellen. Het is opvallend dat dit probleem de laatste jaren behoorlijk is afgenomen. In 2003 vond nog bijna de helft van de bedrijven met wervingsproblemen dat het vervullen van vacatures bemoeilijkt werd doordat sollicitanten een te hoog salaris eisten. Er zijn wel signalen dat te hoge salariseisen in de komende jaren weer meer een probleem zullen worden bij de werving van technisch personeel. "We zullen de komende tijd weer meer moeten gaan betalen dan ons lief is, maar dat is wel nodig om nieuw personeel binnen te halen", denkt een personeelsmanager. Een collega uit een ander bedrijf ziet ook problemen omdat de vakmensen steeds meer gaan eisen: "Het lijkt erop dat de arbeidsvoorwaarden die ICT'ers krijgen zich langzaam doorzetten naar ons bedrijf". Een beperkt aantal bedrijven noemt nog andere problemen bij het vervullen van openstaande vacatures: de grote concurrentie van andere bedrijven in de Metalektro (9\%), te hoge andere eisen van sollicitanten $(7 \%)$ en de concurrentie van andere bedrijven buiten de Metalektro (I\%). Deze problemen zijn echter slechts voor een kleine minderheid van de bedrijven van belang.

\section{Omgaan met wervingsproblemen}

Op welke manieren reageren de bedrijven in de Metalektro op de wervingsproblemen waarmee ze geconfronteerd worden? Allereerst kunnen ze interne aanpassingen doorvoeren om bepaalde wervingsproblemen op te vangen. Figuur 3.9 laat zien dat in 2005 ruim $70 \%$ van de bedrijven met wervingsproblemen hierop reageert door hun personeel flexibel in te zetten. Het is opvallend dat deze interne aanpassing de laatste 
jaren sterk in belang is toegenomen. In 2003 zette nog minder dan een derde van de bedrijven met wervingsproblemen hun personeel flexibel in.

\section{Figuur 3.9}

Interne aanpassingen bij moeilijk vervulbare vacatures voor technisch personeel, 2002-2005 (in \% van de bedrijven met wervingsproblemen)

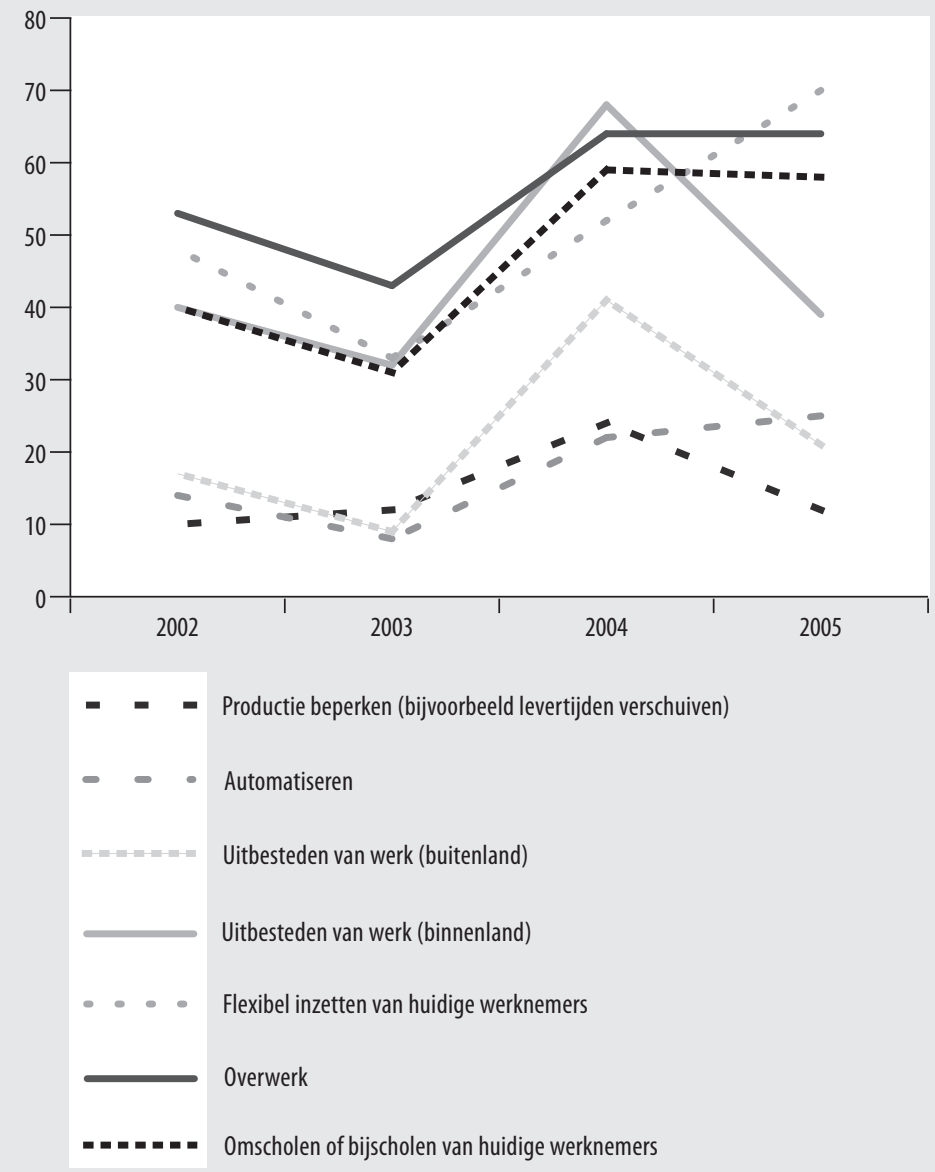

Bron: ROA/Werkgeverspanel Metalektro 2002-2005

Een tweede maatregel om met wervingsproblemen om te gaan is het laten overwerken van het personeel dat bij het bedrijf in dienst is. In maar liefst $64 \%$ van de bedrijven met wervingsproblemen probeerde men dit in 2005 op te vangen door het eigen personeel te laten overwerken. Toch blijven de gevolgen daarvan voor het personeel volgens de metalektrobedrijven vooralsnog beperkt. De personeelsmanager in een bedrijf uit de machine industrie vindt dat de werkdruk zelden uit de hand loopt: "bovendien kunnen onze mensen daar heel goed mee omgaan”. In ander bedrijf ziet men nu nog 
geen grote problemen door overwerk, maar de HRM-manager voegt daar wel aan toe dat hij verwacht dat de problemen de komende tijd groter zullen worden.

Ook het vergroten van de kennis en vaardigheden van het eigen personeel kan ertoe bijdragen dat wervingsproblemen verlicht worden. Bijna $60 \%$ van de bedrijven met wervingsproblemen geeft aan dat ze deze problemen door om- of bijscholing van het huidige personeel probeert te verminderen. Sommige bedrijven gaan er zelfs toe over om voor bepaalde functies het personeel grotendeels zelf op te leiden. Een personeelsmanager van een internationaal opererend bedrijf geeft aan dat ze eigenlijk teruggaan naar hoe het vroeger ging: "We vinden geen personeel op de arbeidsmarkt dat goed genoeg is om als monteur aan de slag te gaan. Daarom gaan we die mensen weer intern werven. Door opleiding en begeleiding proberen we ze vervolgens als het ware naar de functie van monteur toe te laten groeien". Uit de vergelijking met eerdere jaren blijkt overigens dat zowel de inzet van overwerk als het om- of bijscholen van werknemers in belang zijn toegenomen.

Het is opvallend dat het uitbesteden van werk aan binnenlandse of buitenlandse bedrijven als reactie op wervingsproblemen in 2005 aanzienlijk is afgenomen in vergelijking met het jaar daarvoor. In 2004 besteedde nog bijna 70\% van de metalektrobedrijven met problemen bij het vervullen van vacatures werk uit aan bedrijven in het binnenland, terwijl ruim $40 \%$ als reactie op wervingsproblemen werk uitbesteedde aan buitenlandse bedrijven. In 2005 was dat gedaald tot $39 \%$ (binnenland) en $21 \%$ (buitenland). Toch blijkt dat niet voor alle bedrijven het geval te zijn. Een personeelsmanager herkent deze trend helemaal niet: " $\mathrm{Bij}$ ons is het uitbesteden van werk de laatste jaren juist enorm gegroeid".

Bedrijven kunnen er natuurlijk ook toe overgaan om bij wervingsproblemen het productieproces verder te gaan automatiseren. In de praktijk is dat echter slechts voor een minderheid van de bedrijven een optie. In 2005 ging het om een kwart van de metalektrobedrijven. Dat is wel meer dan in 2003. Toen ging nog minder dan IO\% van de bedrijven er bij moeilijk vervulbare vacatures toe over om verder te automatiseren. Slechts weinig bedrijven waren genoodzaakt hun productie te beperken als gevolg van moeilijk vervulbare vacatures. In 2005 beperkte slechts I $2 \%$ van de bedrijven met wervingsproblemen de productie.

Moeilijk vervulbare vacatures kunnen er ook toe leiden dat bedrijven hun wervings- en selectiebeleid gaan aanpassen. Op welke manieren doen ze dat dan vooral? Figuur 3.IO laat zien dat steeds meer bedrijven uitzendbureaus of andere commerciële wervingsbureaus inzetten wanneer er sprake is van moeilijk vervulbare vacatures. In 2003 zette nog slechts $4 \mathrm{I} \%$ van de bedrijven met wervingsproblemen een uitzendbureau in. In 2005 deed maar liefst bijna $80 \%$ van de bedrijven dat. Ook het aantrekken van mensen met minder ervaring is een mogelijkheid om moeilijk vervulbare vacatures ingevuld te krijgen. In 2005 trok circa een derde van de metalektrobedrijven personeel met minder ervaring aan om hun wervingsproblemen te verminderen. Het is echter opval- 
lend dat in 2005 het aantrekken van personeel met minder werkervaring in vergelijking met 2004 duidelijk minder vaak een optie is bij wervingsproblemen.

\section{Figuur 3.10}

Aanpassingen in werving en selectie bij moeilijk vervulbare vacatures voor technisch personeel, 2002-2005 (in \% van de bedrijven met wervingsproblemen)

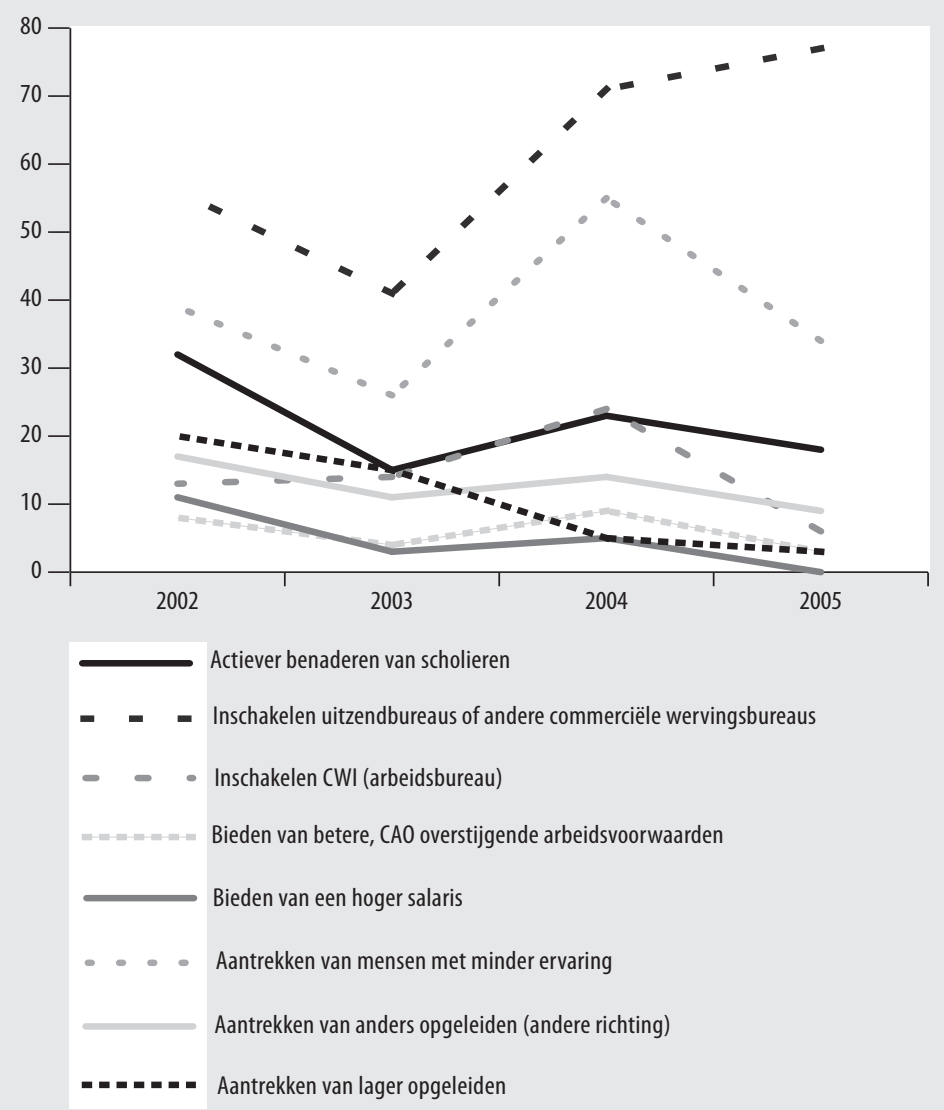

Bron: ROA/Werkgeverspanel Metalektro 2002-2005

De overige maatregelen die op het terrein van werving en selectie genomen kunnen worden om moeilijk vervulbare vacatures ingevuld te krijgen worden telkens slechts door een klein aantal metalektrobedrijven gehanteerd. Daarbij gaat het om het actiever benaderen van scholieren ( $18 \%)$, het aantrekken van anders opgeleiden ( $9 \%)$, het inschakelen van het CWI (6\%), het bieden van betere arbeidsvoorwaarden $(3 \%)$ en het aantrekken van lager opgeleiden (3\%). Het is opmerkelijk dat het aannemen van lager opgeleiden in 2005 veel minder vaak wordt genoemd dan in de jaren daarvoor. In 2002 gaf nog één op de vijf bedrijven aan moeilijk vervulbare vacatures in te vullen 
door lager opgeleid personeel aan te nemen. Het valt ook op dat in 2005 geen enkel bedrijf probeert om de wervingsproblemen te verminderen door het bieden van een hoger salaris. In 2005 konden bedrijven voor het eerst aangeven of ze bij wervingsproblemen arbeidsongeschikten actiever gaan benaderen. Het blijkt dat slechts $3 \%$ van de bedrijven dit doet.

\subsection{Wervingskanalen, gewenste competenties en het imago van het bedrijf}

Welke wervingskanalen vinden de metalektrobedrijven het meest effectief om personeel aan te trekken? Figuur 3.II geeft daarvan, voor het technisch personeel, een overzicht. Het blijkt dat de effectiviteit van de wervingskanalen sterk afhangt van het soort personeel dat bedrijven willen werven. Zo vindt circa een derde van de bedrijven dat uitvoerende en ondersteunende technici het best geworven kunnen worden door gebruik te maken van de diensten van een uitzendbureau. Bij leidinggevend technisch personeel en technisch opgeleide verkopers vinden bedrijven daarentegen het inschakelen van commerciële wervingsbureaus de meest effectieve manier van werven. Het adverteren in een regionaal dagblad wordt door minder bedrijven gezien als een effectief wervingskanaal. Alleen ondersteunde technici worden nog regelmatig op deze manier geworven. Het is opvallend dat advertenties in regionale kranten de laatste jaren door steeds minder bedrijven als effectief worden gezien. In 2004 vond nog $28 \%$ van de bedrijven dat uitvoerende technici effectief via regionale advertenties konden worden geworven. In 2005 vond nog slechts I $2 \%$ van de bedrijven dat.

De rol van internet als effectief wervingsinstrument is daarentegen iets belangrijker geworden, maar de ontwikkeling gaat nog niet snel. In 2004 vond $5 \%$ van de bedrijven dat uitvoerende technici effectief via internet geworven kunnen worden; in 2005 vond $7 \%$ van de bedrijven het internet een effectief wervingsinstrument. Toch zijn er ook bedrijven waarbij het werven via internet een de afgelopen jaren een grote vlucht genomen heeft. Een HRM-manager van een high-tech bedrijf spreekt zelfs van een onmiskenbare digitalisering van de arbeidsmarkt: "We lopen voorop bij het bedenken en implementeren van digitale arbeidsmarktstrategieën. We hebben sinds enige tijd ook een database met potentiële kandidaten en we proberen die mensen voor het bedrijf te winnen door ze gepersonaliseerde direct e-mail te sturen. Dat we hier zo sterk mee bezig zijn komt natuurlijk ook doordat we vooral hoogopgeleiden werven". Maar ook bij het aantrekken van middelbaar en lager opgeleid personeel wordt het internet steeds belangrijker. Een Limburgs metalektrobedrijf maakt voor het werven van middelbaar opgeleid personeel al enkele jaren gebruik van Limburgvac (een vacaturebank die via internet te raadplegen is) en is daar zeer tevreden mee. Een ander geïnterviewd bedrijf maakt geen gebruik van digitale vacaturebanken, maar geeft wel aan dat de eigen website de afgelopen jaren een belangrijke "tool" bij het aantrekken van nieuw personeel is geworden. 
Figuur 3.11

Meest effectieve wervingskanalen voor technisch personeel, 2005 (\% bedrijven)

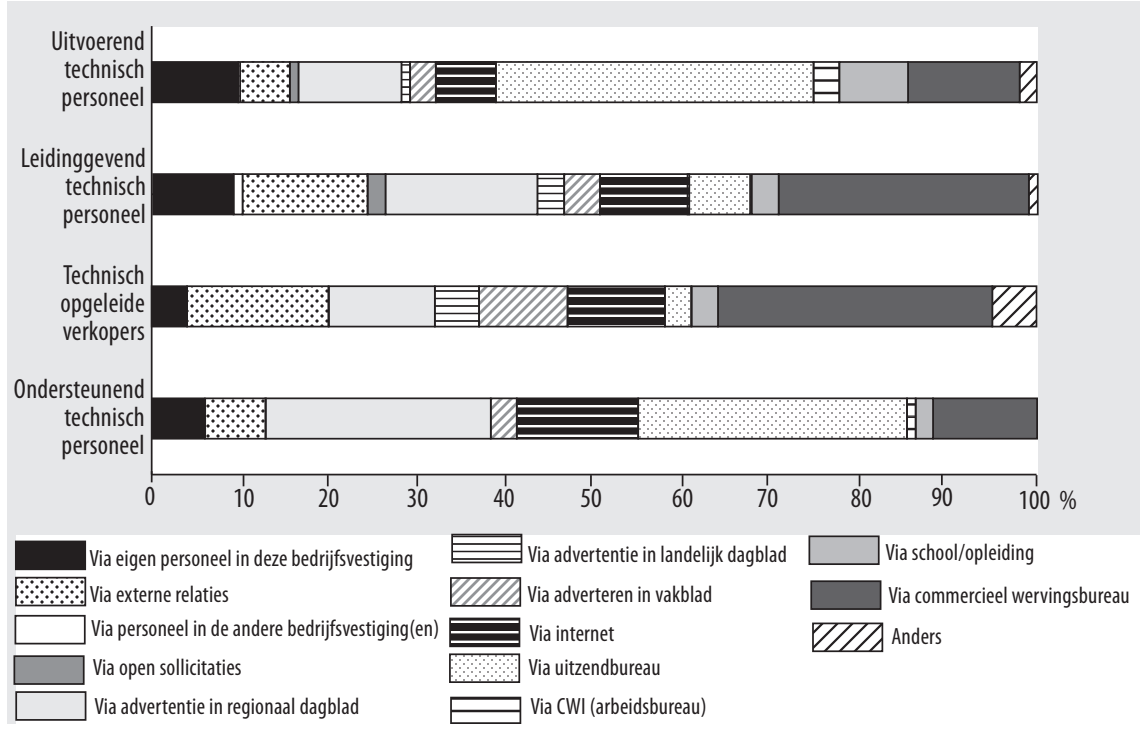

Bron: ROA/Werkgeverspanel Metalektro 2005

Externe relaties zijn vooral van belang bij het werven van leidinggevende technici en technisch opgeleide verkopers. Circa $15 \%$ van de bedrijven vindt dat leidinggevende technici en technisch opgeleide verkopers effectief via externe relaties kunnen worden aangetrokken. De overige in figuur 3.II genoemde wervingskanalen zijn slechts voor een klein aantal bedrijven van belang. Een opvallende uitkomst uit de interviews met bedrijven is dat informele manieren van personeelswerving in de praktijk erg goed werken. Sommige bedrijven vinden zelfs dat het informele circuit of 'mond-opmond reclame' de beste manieren zijn om personeel aan te trekken. Een enthousiaste HRM-manager licht verder toe: "Het werkt gewoon veel beter dan andere kanalen. We stimuleren het informeel werven ook flink. Als er iemand nieuw bij ons in dienst komt, dan zeggen we altijd: zeg, als je nog iemand anders weet ...”.

\section{Gewenste competenties bij de werving van nieuw personeel}

Waarop selecteren bedrijven wanneer ze technisch personeel aannemen? Figuur 3.I2 laat zien dat de meeste bedrijven nog steeds het meeste kijken naar het niveau van de vaktechnische vaardigheden van sollicitanten. Maar liefst $93 \%$ van de bedrijven vindt dit één van de belangrijkste competenties. Drie andere belangrijke competenties bij het selecteren van technisch personeel zijn probleemoplossend vermogen, werken in teamverband en flexibiliteit. Meer dan de helft van de metalektrobedrijven selecteert het nieuwe personeel op basis van deze competenties. Goed zelfstandig kunnen werken wordt door $39 \%$ van de bedrijven gezien als belangrijke competentie bij het werven van nieuw personeel. 
Figuur 3.12

Belangrijkste competenties bij het aannemen van technisch personeel, 2005 (\% bedrijven)

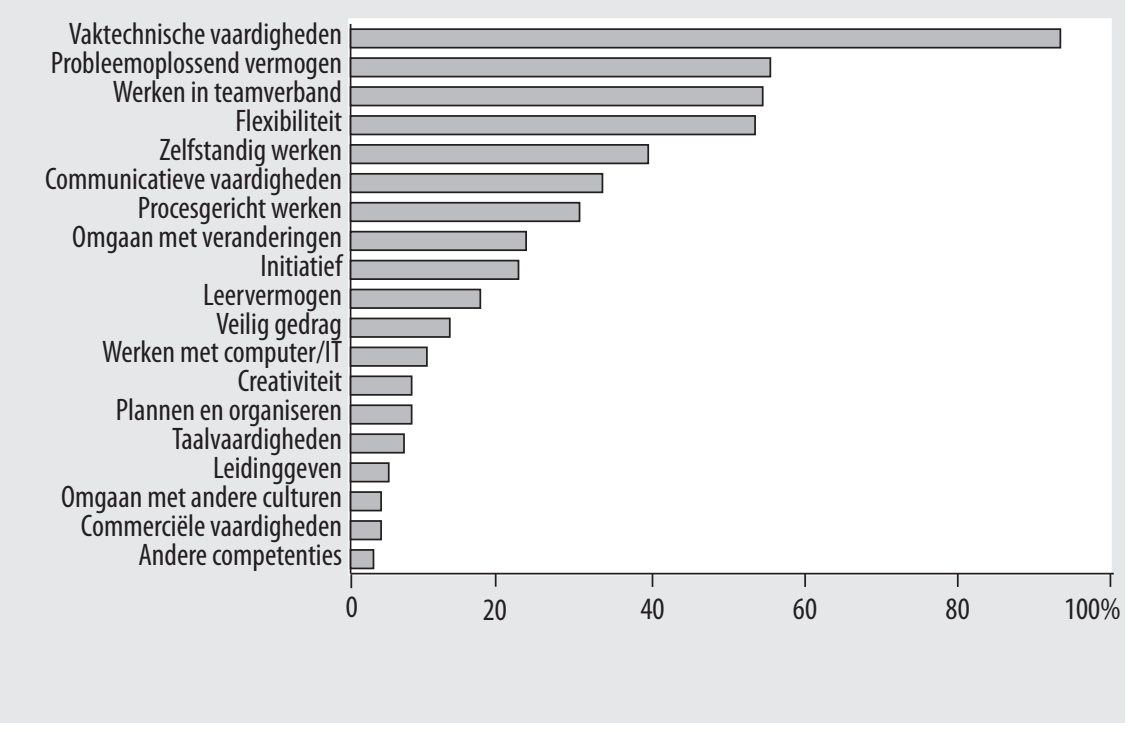

Bron: ROA/Werkgeverspanel Metalektro 2005

Circa een derde van de bedrijven selecteert nieuwe werknemers op basis van hun communicatieve vaardigheden. Procesgericht kunnen werken is voor $30 \%$ van de bedrijven van belang in het selectieproces. De overige competenties in figuur 3.I2 zijn telkens voor een minder dan een kwart van de bedrijven van belang. Het is waarschijnlijk dat de bedrijven die hun nieuwe personeel op deze competenties selecteren wat afwijken van het gemiddelde beeld van de Metalektro, bijvoorbeeld doordat ze een uniek productieproces hebben.

Ook uit de gesprekken met deelnemers aan het werkgeverspanel kwam duidelijk naar voren dat naast vakkennis ook andere competenties in grote mate bepalen of een kandidaat in dienst wordt genomen. Een personeelsmanager vertelt: "het is minstens zo belangrijk dat nieuwe werknemers ook goed kunnen werken in een team en meer in het algemeen een positieve bijdrage kunnen leveren aan de productiviteit”. Een ander bedrijf benadrukt het belang van interpersoonlijke vaardigheden en de ontwikkelingsbereidheid: "Onze technici moeten niet te introvert zijn, ze moeten immers ook goed met klanten overweg kunnen. Daarnaast is het van belang dat ze ontwikkelingsgericht zijn. Mensen die niet verder kijken dan hun huidige werk, daar hebben we niet zoveel meer aan".

\section{Het imago van het bedrijf}

Volgens veel bedrijven die deelnamen aan de interviews kan het succes van hun wervingsbeleid voor een groot deel verklaard worden door hun goede imago op de 
arbeidsmarkt. Een goed imago kan dus bijdragen aan de mate waarin bedrijven in staat zijn geschikt personeel aan te trekken. Dat werpt de vraag op welke activiteiten bedrijven concreet ondernemen om ervoor te zorgen dat ze een goed imago hebben op de arbeidsmarkt. Figuur 3.I3 geeft daarvan een overzicht. Maar liefst twee derde van de bedrijven probeert het eigen imago te versterken door contacten met het voortgezet onderwijs. $42 \%$ van de bedrijven organiseert bedrijfsexcursies om het bedrijfsimago te versterken en $35 \%$ van de bedrijven is actief bezig om het werk dat binnen het bedrijf gedaan wordt te promoten. Ten slotte probeert circa I $5 \%$ van de bedrijven door contacten met het basisonderwijs het imago te versterken.

\section{Figuur 3.13}

Activiteiten om te zorgen voor een goed imago van het bedrijf, 2005 (\% bedrijven)

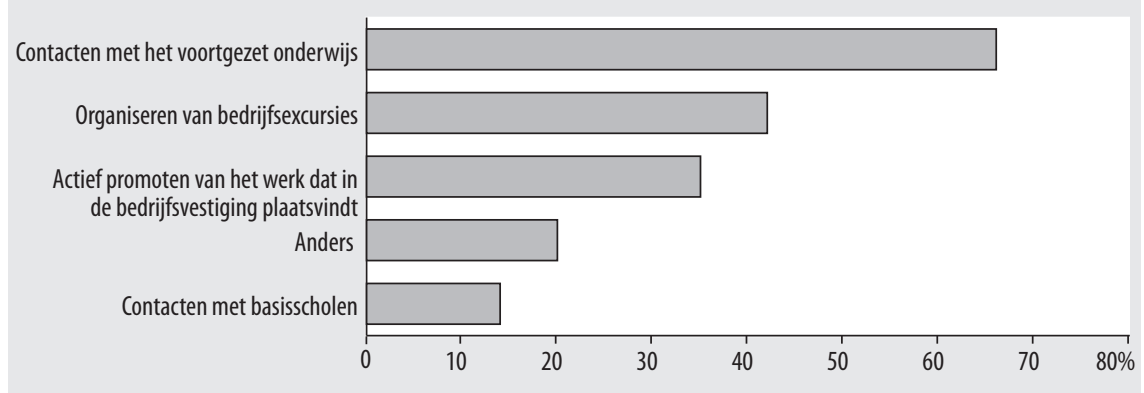

Bron: ROA/Werkgeverspanel Metalektro 2005

Ook uit gesprekken met bedrijven kwam naar voren dat nogal wat bedrijven erg veel waarde hechten aan goede contacten met het onderwijs. Waarom is dat zo? Een personeelsfunctionaris van een middelgroot bedrijf: "We organiseren contacten met scholen en organiseren regelmatig rondleidingen. Het is echt nodig dat er een goed contact met de scholen bestaat. Ze moeten immers het personeel opleiden dat wij in de toekomst nodig hebben". Het is volgens haar ook van groot belang om scholieren op een leuke manier kennis te laten maken met de Metalektro. Ze is erg enthousiast over het pas afgesloten project 'de fabriek' waarin VMBO scholieren de industrie op speelse wijze leren kennen. In elektrotechnisch bedrijf gebeurt iets vergelijkbaars: "Onze ingenieurs gaan voor de klas staan op middelbare scholen. In de klas halen we huishoudelektronica helemaal uit elkaar, en vertellen de leerlingen hoe iets werkt met als doel een interesse voor techniek op te wekken”.

Uit enkele interviews kwam daartentegen ook naar voren dat sommige bedrijven tevreden zijn met hun imago op de arbeidsmarkt en daarom geen actie ondernemen om hun imago te verbeteren. Een HRM-manager: Onze goede naam vergemakkelijkt het vinden van goed personeel. We denken niet dat we ons imago verder moeten verbeteren, en daarom is het niet echt nodig om extra acties te ondernemen. Bij een ander bedrijf vindt de personeelsfunctionaris dat ook, maar hij voegt er wel aan toe dat het bereik van het imago van het bedrijf buiten de eigen regio beperkt is: "Dat 
is geen groot probleem. We werven ons personeel toch grotendeels in onze eigen regio".

\subsection{Werven in het buitenland}

\section{Aantal werknemers uit het buitenland}

Hoeveel werknemers halen de metalektrobedrijven uit het buitenland en om wat voor soort mensen gaat het dan vooral? In 2005 is in het werkgeverspanel gevraagd hoeveel buitenlandse werknemers de metalektrobedrijven in dienst hebben. Het blijkt in totaal te gaan om bijna 2.200 werknemers, wat neerkomt op iets meer dan I\% van de totale personeelsomvang. Figuur 3.I4 laat zien dat het bij het grootste gedeelte van de werknemers van buitenlandse origine gaat om mensen met een opleiding op middelbaar niveau. Er worden ook hoogopgeleide werknemers uit het buitenland aangetrokken, maar in vergelijking met het aantal Nederlandse hoogopgeleide werknemers is dat aantal relatief laag.

\section{Figuur 3.14}

Personeel uit het buitenland naar opleidingsniveau, 2005 (\% werknemers)
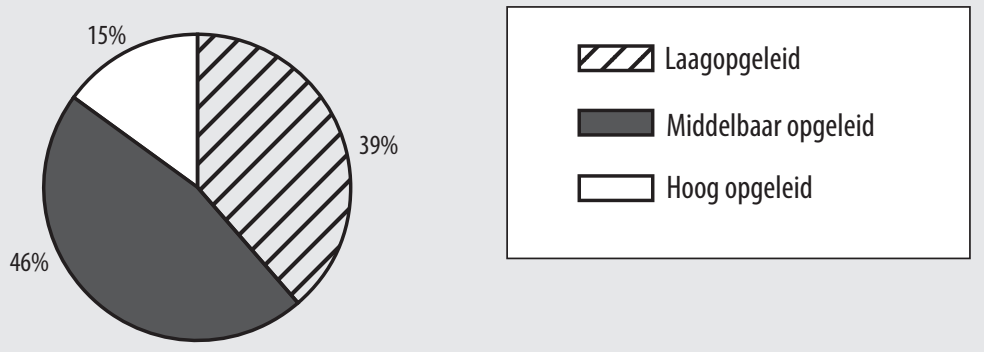

Bron: ROA/Werkgeverspanel Metalektro 2005

Wordt het werven van buitenlands personeel de komende jaren belangrijker? Figuur 3.I5 laat zien dat bijna de helft van de bedrijven hierover geen uitgesproken mening heeft. $29 \%$ verwacht niet dat ze in de komende jaren meer werknemers in het buitenland gaan werven. Circa een kwart van de bedrijven denkt dat het werven in het buitenland de komende jaren wél in belang zal toenemen. Vooral bedrijven die veel hoogopgeleid personeel aantrekken denken dat er meer in het buitenland geworven zal gaan worden. Een groot high tech bedrijf: "Omdat de beschikbaarheid van technisch opgeleide schoolverlaters afneemt is werven in het buitenland een reële optie". Een ander bedrijf vindt dat het werven van personeel in het buitenland weliswaar een goede oplossing zou zijn bij krapte op de arbeidsmarkt, maar dat het aantrekken van hoger opgeleide werknemers erg moeizaam verloopt: "we zitten vlak bij de Duitse 
grens, en hebben al tevergeefs gezocht naar Duits personeel voor enkele hogere functies. Daarom gaan we in de toekomst mogelijk ook engineering naar het buitenland verplaatsen, misschien zelfs wel naar Azië”. Een derde bedrijf lukt het daarentegen wel om hoger opgeleid personeel uit Duitsland aan te trekken. Het gaat hier echter om technische verkopers, die actief zijn op de Duitse markt.

\section{Figuur 3.15}

Verwachting dat belang van werven in het buitenland de komende jaren zal toenemen, 2005 (\% bedrijven)
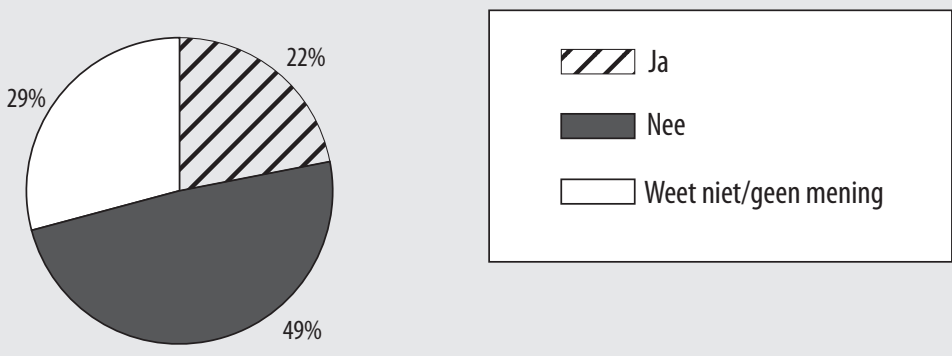

Bron: ROA/Werkgeverspanel Metalektro 2005

\section{Herkomst van buitenlandse werknemers}

Waar komen de buitenlandse werknemers vooral vandaan? Figuur 3.I6 laat duidelijk zien dat het in bijna alle bedrijven (88\%) gaat om personeel dat afkomstig is uit de EU. $8 \%$ van de bedrijven werft zowel binnen als buiten de EU. Slechts $4 \%$ van de Nederlandse metalektrobedrijven werft alleen werknemers van buiten de EU.

\section{Figuur 3.16}

Personeel uit het buitenland naar herkomst, 2005 (\% bedrijven)
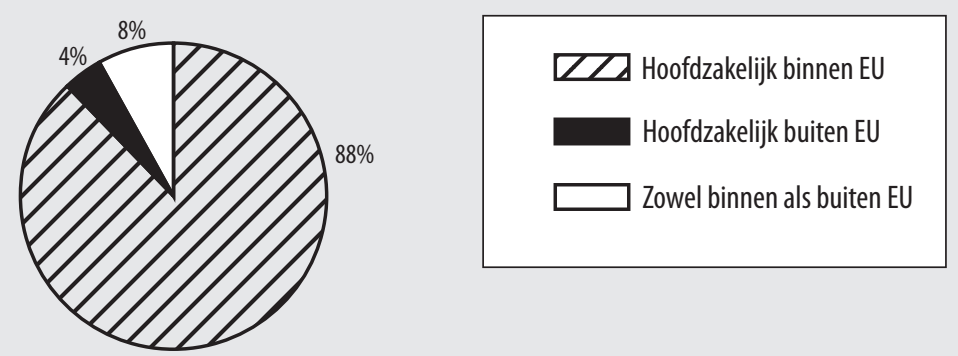

Bron: ROA/Werkgeverspanel Metalektro 2005 


\section{Waarom werven bedrijven in het buitenland?}

Waarom gaan bedrijven in de Metalektro ertoe over om personeel in het buitenland te werven? Figuur 3.17 laat zien dat bedrijven daarvoor drie redenen hebben. Allereerst werft $58 \%$ van de bedrijven personeel in het buitenland omdat dat personeel ook in het buitenland aan de slag gaat. Het kan dan bijvoorbeeld gaan om verkopers die in hun land van herkomst voor een Nederlands bedrijf producten verkopen. $42 \%$ van de bedrijven trekt buitenlands personeel aan omdat er binnen Nederland onvoldoende gekwalificeerd personeel voorhanden is. Ten slotte is er nog een groep bedrijven die buitenlands personeel aantrekken vanwege hun goede arbeidsmentaliteit: $17 \%$ van de metalektrobedrijven zegt buitenlands personeel aan te trekken omdat ze denken dat personeel uit het buitenland een betere arbeidsmentaliteit heeft dan Nederlandse werknemers.

\section{Figuur 3.17}

Redenen om in het buitenland te werven, 2005 (\% bedrijven)

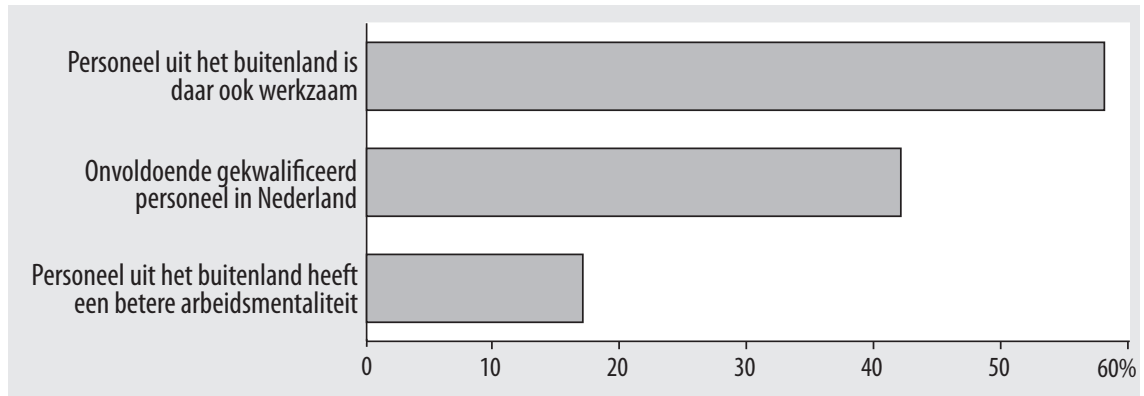

Bron: ROA/Werkgeverspanel Metalektro 2005

Sommige bedrijven werven momenteel niet in het buitenland maar hebben dat in het verleden wel gedaan en er zijn duidelijke verschillen in de ervaringen daarmee. Een HRM-manager: "We hebben een aantal Oost-Duitsers in dienst, die al heel lang bij ons zijn en die het heel goed doen. Destijds hebben we die groep via een Nederlands uitzendbureau binnengehaald. Ze presteren goed, maar niet beter dan vergelijkbare Nederlanders". Een ander bedrijf vindt dat buitenlandse werknemers wél beter presteren: "Een aantal jaar geleden hadden we op uitzendbasis een aantal Duitse en Poolse werknemers aan het werk. Dat is erg goed bevallen. Ze waren bereid tot vele uren inzet, hadden veel ervaring en waren bijzonder goed gemotiveerd". 


\section{Instroom van schoolverlaters}

"Schoolverlaters moeten nadat ze in dienst komen nog verder ontwikkeld worden. Het zijn ruwe diamanten die door ons nog verder gepolijst worden".

"We nemen nooit schoolverlaters in dienst, we selecteren liever mensen met ervaring".

"We nemen wel eens schoolverlaters aan, maar we letten er dan wel op dat ze goed kunnen werken in een team”.

"We kijken natuurlijk naar het opleidingsniveau en de richting die schoolverlaters gevolgd hebben, maar daarnaast zijn persoonlijkheid, ambitieniveau en uitstraling ook sleutelbegrippen".

"Wat van groot belang is, is dat een schoolverlater bij onze organisatie past".

"We proberen op verschillende manieren schoolverlaters voor ons bedrijf te winnen. Via internet laten we mogelijke kandidaten een virtuele werkomgeving zien, waarin bedrijfsprocessen worden gesimuleerd".

"Schoolverlaters die bij ons in dienst komen moeten verder durven kijken dan hun eigen vakgebied".

De citaten laten zien dat er binnen de metalektrobedrijven heel uiteenlopend wordt gedacht over schoolverlaters. Tot op heden is er op het niveau van de metal en elektrotechnische sector echter weinig bekend over de rol die schoolverlaters spelen bij het vervullen van een gedeelte van de personeelsbehoefte. Daarom gaan we in dit hoofdstuk in op de instroom van schoolverlaters. We kijken eerst naar de kenmerken van de instroom: Hoeveel schoolverlaters stromen er in, waar komen ze terecht en wat voor opleidingen hebben ze gevolgd. Daarna gaan we in op het marktaandeel en de concurrentiepositie van de metaal en elektrotechnische sector ten opzichte van andere sectoren. In het laatste gedeelte van dit hoofdstuk proberen we een antwoord te geven op de vraag in hoeverre het onderwijsveld de komende jaren meer aandacht aan bepaalde competenties zou moeten schenken, om zo competentietekorten die bedrijven bij hun jonge personeel ervaren te kunnen verminderen. 


\subsection{Welke schoolverlaters stromen in?}

Een gedeelte van de behoefte aan nieuw personeel van de bedrijven in de metaal en elektrotechnische sector wordt ingevuld door schoolverlaters aan te nemen. Maar hoeveel schoolverlaters stromen er in en welk opleidingsniveau hebben ze? Welk diploma hebben ze op zak? En hoe zit het met de verdeling man/vrouw? Bij het beantwoorden van deze vragen zijn we genoodzaakt om gebruik te maken van cijfers over de gehele Nederlandse metaal en elektrotechnische sector. Hierdoor kunnen de cijfers enigszins vertekend zijn.

\section{Opleidingsniveau}

In 2004 namen de bedrijven in de metaal en elektrotechnische sector in totaal circa 4.000 schoolverlaters aan. Dat is heel wat minder dan in voorgaande jaren. In $200 \mathrm{I}$ werden er nog bijna 7.000 schoolverlaters aangetrokken. Dit terwijl het totaal aantal schoolverlaters dat op de Nederlandse arbeidsmarkt instroomde in dezelfde periode met ruim 9.000 toenam. Dit betekent dat de daling van het aantal schoolverlaters dat een baan vond in de metaal en elektrotechnische sector andere oorzaken heeft. Het kan betekenen dat de bedrijven steeds meer de voorkeur geven aan nieuw personeel met werkervaring. Een andere mogelijke verklaring is dat de metalektrobedrijven in het algemeen minder nieuwe werknemers zijn gaan werven, omdat ze geconfronteerd zijn met een krimpende werkgelegenheid (zie ook hoofdstuk 2).

In figuur 4.I kijken we naar het opleidingsniveau van de schoolverlaters die in 2003 en 2004 een baan vonden in de metaal en elektrotechnische sector. De meeste van deze schoolverlaters hebben een opleiding op middelbaar beroepsniveau. Zo heeft $20 \%$ van de ingestroomde schoolverlaters een BBL-opleiding op niveau I of 2 afgelegd. I2\% van de schoolverlaters die in 2004 in de metaal en elektrotechnische sector aan de slag ging heeft een BOL-opleiding op niveau 3 of 4 gevolgd. De werkgelegenheidsaandelen van schoolverlaters met een BOL-opleiding op niveau I of 2 of een BBL-opleiding op niveau 3 of 4 zijn geringer: respectievelijk $3 \%$ en $8 \%$.

De figuur laat ook zien dat het $\mathrm{HBO}$ een grote leverancier is van nieuwe arbeidskrachten in de metaal en electrotechnische sector. Bij maar liefst een kwart van de schoolverlaters ging het om een HBO'er. De instroom van universitair afgestudeerden is een stuk kleiner: $9 \%$ van de schoolverlaters die in 2003 en 2004 in de metaal en elektrotechnische sector aan de slag ging had een universitair diploma op zak.

Dat heel wat schoolverlaters die in de metaal en elektrotechnische sector aan de slag gaan middelbaar of hoger opgeleid zijn betekent niet dat de bedrijven helemaal geen lager opgeleid personeel meer aantrekken. In 2003/2004 had 23\% van de schoolverlaters die in de metaal en elektrotechnische sector gingen werken een opleiding VMBO. Uit achterliggende gegevens blijkt echter dat bijna de helft van de instromers van het $\mathrm{VMBO}$ een BBL-opleiding volgt. Dit betekent dat bedrijven in de metaal en elektro- 
technische sector weliswaar laagopgeleid personeel aannemen, maar dat deze laagopgeleide werknemers voor een aanzienlijk deel door de bedrijven zelf tot middelbaar niveau worden opgeleid.

\section{Figuur 4.1}

Opleidingsniveau van ingestroomde schoolverlaters in de metaal en elektrotechnische sector, 2003-2004 (\%)

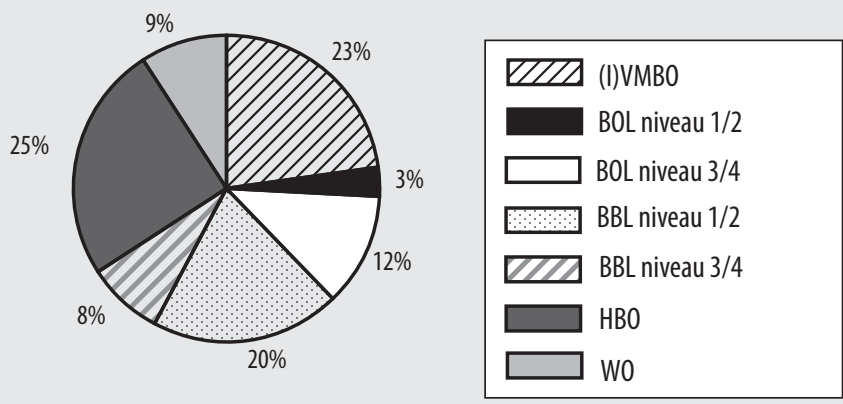

Bron: ROA schoolverlatersinformatiesysteem 2003-2004

\section{Belangrijke opleidingsrichtingen}

Welke opleidingen hebben schoolverlaters die de metaal en elektrotechnische sector instromen gevolgd? Figuur 4.2 geeft een overzicht van de belangrijkste opleidingsrichtingen. Het blijkt dat de meeste schoolverlaters een opleiding $\mathrm{MBO}$ werktuigbouwkunde en mechanische techniek hebben gevolgd (2I\%). I3\% van de ingestroomde schoolverlaters heeft een VMBO-opleiding metaal gevolgd. Het aandeel van de opleiding $\mathrm{HBO}$ werktuigbouwkunde bedraagt $8 \%$, terwijl het bij bijna $7 \%$ van de instroom ging om HBO'ers met een opleiding bedrijfskunde. De aandelen van de overige in figuur 4.2 genoemde opleidingen zijn allemaal een stuk kleiner. 


\section{Figuur 4.2}

Belangrijkste opleidingsrichtingen van ingestroomde schoolverlaters in de metaal en elektrotechnische sector, 2003-2004 (\%)

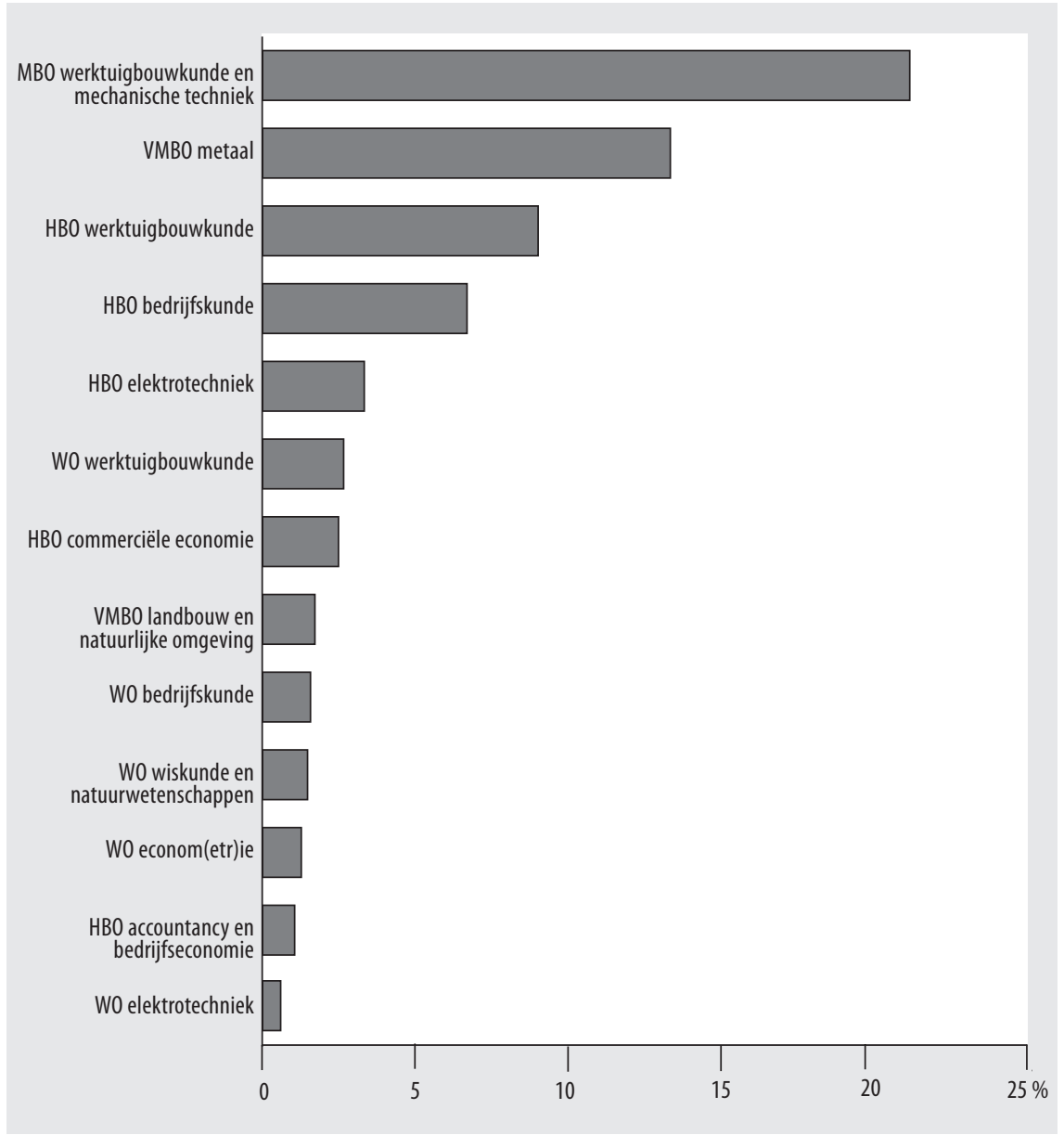

Bron: ROA schoolverlatersinformatiesysteem 2003, 2004

\section{Vrouwelijke schoolverlaters}

Traditioneel trekken technische opleidingen vooral mannelijke studenten. Dat werpt de vraag op hoe het staat met het percentage vrouwen dat na het voltooien van hun opleiding in de metaal en elektrotechnische sector aan de slag gaat. Figuur 4.3 laat zien dat in 2004 circa $9 \%$ van het totaal aantal schoolverlaters met werk in de metaal en elektrotechnische sector vrouw is. Opvallend is de sterke teruggang van het aandeel vrouwelijke schoolverlaters dat in de metaal en elektrotechnische sector ging werken. In 2000 was het aandeel van vrouwen in de totale instroom immers twee keer zo 
groot: $18 \%$. Gezien de verwachte knelpunten in de toekomstige personeelsvoorziening is dit een zorgelijke ontwikkeling.

\section{Figuur 4.3}

Vrouwelijke schoolverlaters werkzaam in de metaal en elektrotechnische sector, 1999-2004 (\%)

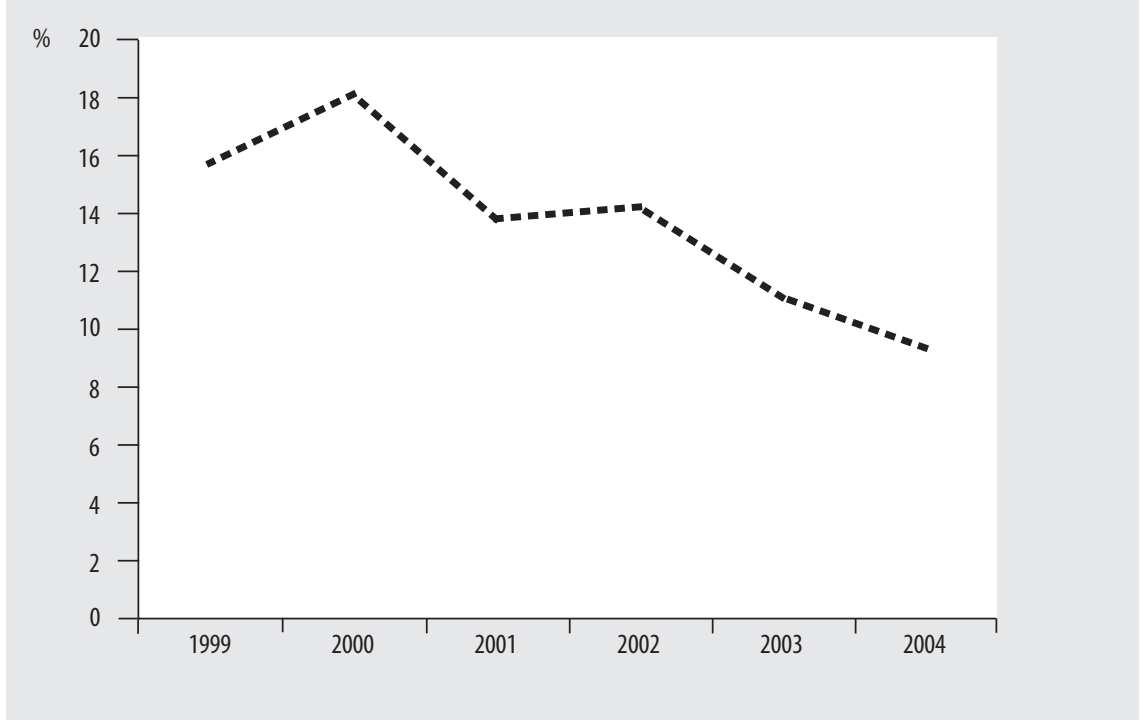

Bron: ROA schoolverlatersinformatiesysteem 1999-2004

\subsection{Marktaandeel en concurrentiepositie}

Hoeveel van het totale aanbod van schoolverlaters komt uiteindelijk in een bedrijf in de metaal en elektrotechnische sector terecht? We spreken dan van het marktaandeel. Figuur 4.4 laat zien dat het marktaandeel van de metaal en elektrotechnische sector vrij beperkt is. Slechts 3,4\% van het totale aanbod van schoolverlaters ging in 2003 of 2004 aan de slag bij een bedrijf in de metaal en elektrotechnische sector. De instroom van schoolverlaters is veel groter voor een aantal andere bedrijfssectoren, zoals bijvoorbeeld de kwartaire diensten, de horeca en de zakelijke dienstverlening. Binnen de metaal en elektrotechnische sector zijn er wel aanzienlijke verschillen. Zo komt I, $4 \%$ van het totale aanbod van schoolverlaters te werken in een bedrijf in de machine industrie, terwijl het aandeel dat de basismetaal voor haar rekening neemt veel kleiner is: $0, \mathrm{I} \%$. 


\section{Figuur 4.4}

Marktaandeel per bedrijfssector, 2003-2004 (\% van totaal aantal ingestroomde schoolverlaters)

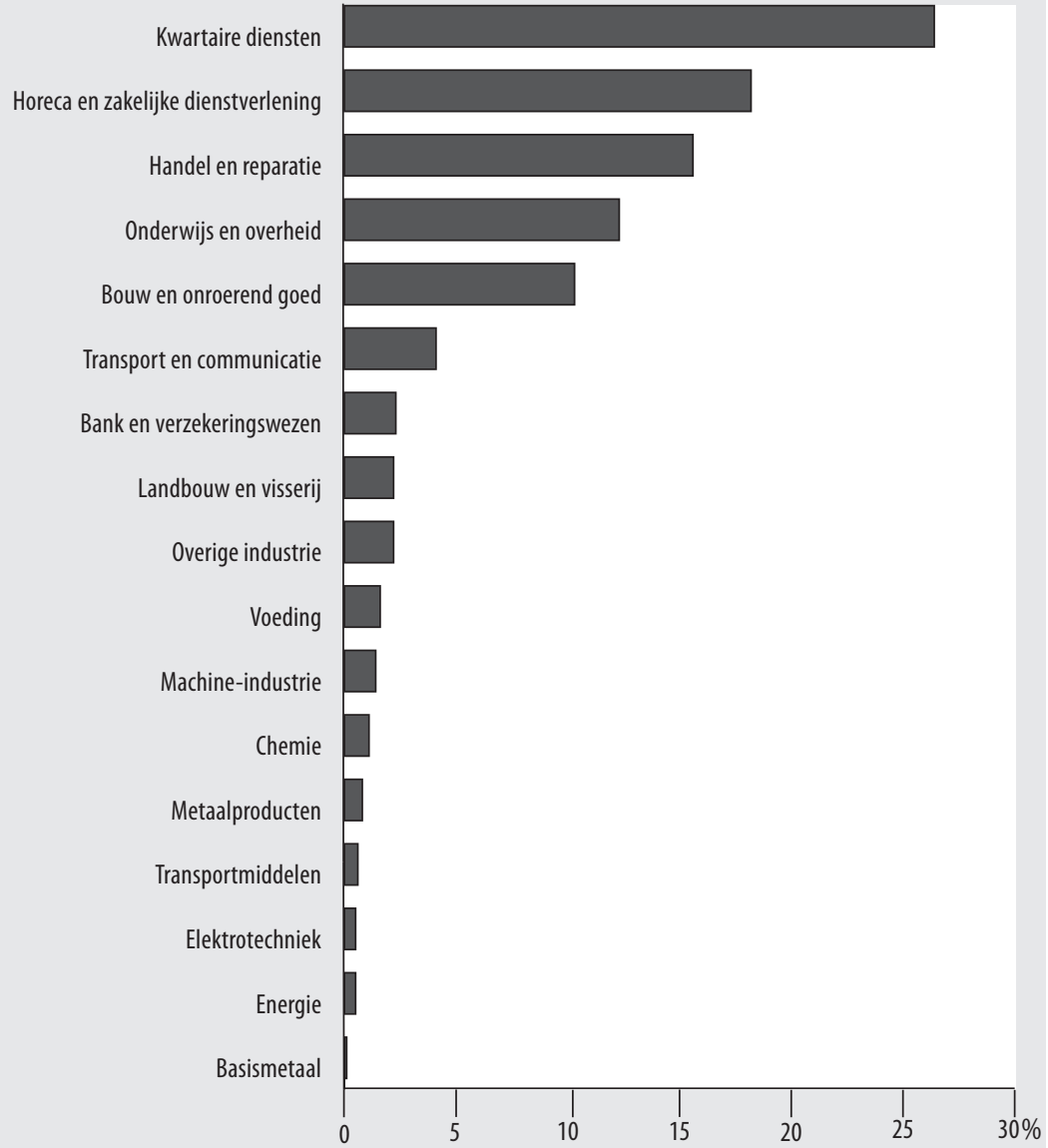

Bron: ROA schoolverlatersinformatiesysteem 2003, 2004

\section{Concurrentiepositie}

Dat het aandeel van schoolverlaters dat uiteindelijk in een bedrijf in de metaal en elektrotechnische sector terecht komt vrij klein is, betekent dat de sector moet concurreren met andere bedrijfssectoren om schoolverlaters aan te kunnen trekken. Maar met welke sectoren wordt er vooral geconcurreerd? Om hier enig inzicht in te krijgen kijken we naar de concurrentiepositie van de metaal en elektrotechnische sector voor de drie opleidingen die het grootste aandeel hebben in de instroom van schoolverlaters. Het gaat hier om de opleidingen $\mathrm{MBO}$ werktuigbouwkunde en mechanische techniek, VMBO metaal en $\mathrm{HBO}$ werktuigbouwkunde. Deze drie opleidingen vertegenwoordigen ruim $40 \%$ van de totale instroom van schoolverlaters in de metaal en 
elektrotechnische sector. Om betrouwbare gegevens te kunnen presenteren kijken we naar cijfers voor de jaren 1999-2004.

Figuur 4.5 laat zien dat de concurrentiepositie van de metaal en elektrotechnische sector bij het aantrekken van schoolverlaters met een opleiding $\mathrm{MBO}$ werktuigbouwkunde en mechanische techniek relatief goed is: circa de helft van de schoolverlaters die deze opleiding voltooid hebben gaat er aan de slag. $2 \mathrm{I} \%$ gaat werken in de machine-industrie, terwijl I7\% terecht komt in de metaalproductensector. Daarnaast gaat IO\% van het totale aantal schoolverlaters met een opleiding $\mathrm{MBO}$ werktuigbouwkunde en mechanische techniek aan het werk in de transportmiddelensector. In de overige sectoren binnen de metaal en elektrotechnische sector stromen daarentegen slechts weinig schoolverlaters in die een opleiding $\mathrm{MBO}$ werktuigbouwkunde en mechanische techniek hebben afgerond. Om schoolverlaters met deze opleiding aan te trekken, concurreert de metaal en elektrotechnische sector in beperkte mate met twee bedrijfssectoren: Bouw en onroerend goed en horeca en zakelijke dienstverlening. Deze sectoren nemen respectievelijk I $4 \%$ en $7 \%$ van het totale aantal schoolverlaters met een opleiding $\mathrm{MBO}$ werktuigbouwkunde en mechanische techniek in dienst.

\section{Figuur 4.5}

Bestemming van schoolverlaters met een opleiding MBO werktuigbouwkunde en mechanische techniek, 1999-2004 (\%)
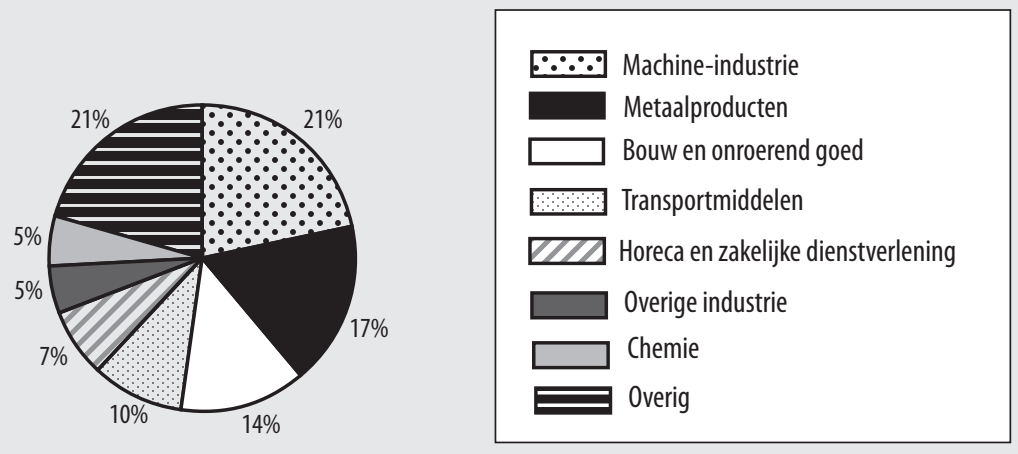

Bron: ROA schoolverlatersinformatiesysteem 1999-2004

Figuur 4.6 laat zien in welke bedrijfssectoren schoolverlaters met een opleiding VMBO metaal terechtkomen. Het blijkt dat $2 \mathrm{I} \%$ van de schoolverlaters die deze opleiding afgerond hebben aan de slag gaan in de bouw. Op de tweede en derde plaats komen twee sectoren die deel uitmaken van de metaal en elektrotechnische industrie: $16 \%$ van de schoolverlaters met een opleiding VMBO metaal gaat werken in de metaalproductensector; I4\% gaat aan de slag in de machine industrie. Dit betekent dat van het totaal aantal schoolverlaters met een diploma VMBO metaal circa een 
derde in de metaal en elektrotechnische sector gaat werken. De sector ondervindt bij de werving van schoolverlaters met een $\mathrm{VMBO}$ opleiding metaal enige concurrentie van de bouwsector, de sector handel en reparatie, de transport en communicatiesector en de horeca en zakelijke dienstverlening.

\section{Figuur 4.6}

Bestemming van schoolverlaters met een opleiding VMBO metaal, 1999-2004 (\%)
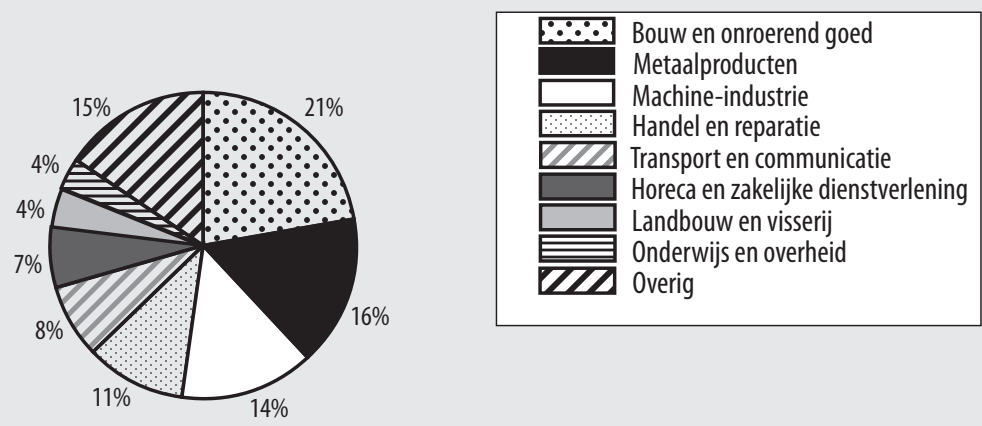

Bron: ROA schoolverlatersinformatiesysteem 1999-2004

Figuur 4.7 laat zien dat maar liefst $28 \%$ van schoolverlaters die een opleiding HBO werktuigbouwkunde afgerond hebben terechtkomen in de horeca en zakelijke dienstverlening. I7\% van het aantal schoolverlaters met een dergelijke opleiding komt terecht in de machine-industrie, terwijl $9 \%$ van het totaal aantal afgestudeerde HBO'ers werktuigbouwkunde aan de slag gaat in de transportmiddelenindustrie. De sectoren bouw en onroerend goed en handel en reparatie nemen ieder $8 \%$ van het totale aanbod van afgestudeerde HBO'ers met een opleiding werktuigbouwkunde voor hun rekening. Voor de sectoren elektrotechniek en metaalproducten bedraagt de instroom van werktuigbouwkundigen $5 \%$ van het totale aanbod. Al met al kan gesteld worden dat de concurrentiepositie van de metaal en elektrotechnische sector, ondanks de concurrentie met vooral de horeca en zakelijke dienstverlening en de bouwsector, relatief goed is. De sector weet namelijk circa $40 \%$ van het totaal aantal HBO'ers met een afgeronde opleiding werktuigbouwkunde aan te trekken.

De bedrijven waarmee interviews gehouden werden, zijn in het algemeen redelijk positief over de concurrentiepositie van hun bedrijf. Ze geven wel vaak aan dat effectief kunnen concurreren niet alleen te maken heeft met de situatie op de arbeidsmarkt, maar ook met het soort werk en de voorwaarden die ze schoolverlaters kunnen bieden. Een personeelsfunctionaris: "Onze concurrentiepositie is goed omdat we een leuk bedrijf zijn dat de mensen veel vrijheid biedt. We werken in projecten en proberen de werknemers overal bij te betrekken. Natuurlijk spelen onze arbeidsvoor- 
waarden ook een rol, maar ik denk dat schoolverlaters ook erg belangrijk vinden dat bij ons de sfeer erg goed is".

\section{Figuur 4.7}

Bestemming van schoolverlaters met een opleiding HBO werktuigbouwkunde, 1999-2004 (\%)


Bron: ROA schoolverlatersinformatiesysteem 1999-2004

\subsection{Aansluiting tussen opleiding en baan}

In hoeverre sluit de opleiding die schoolverlaters gevolgd hebben aan bij het werk dat ze uiteindelijk gaan doen in de metaal en elektrotechnische sector? In figuur 4.8 kijken we naar de mate waarin schoolverlaters vinden dat ze werk doen waarvoor het gevraagde opleidingsniveau lager is dan het opleidingsniveau dat ze hebben. Dit is een indicator voor de onderbenutting van de opleiding van schoolverlaters. Daarnaast geeft de figuur een beeld van de aansluiting qua richting. Er wordt gekeken in hoeverre schoolverlaters vinden dat ze een baan hebben waarvoor een andere richting vereist is dan de richting waarin ze zijn opgeleid.

De figuur laat zien dat in 2004 circa IO\% van de schoolverlaters die in de basismetaal aan de slag gingen onder hun niveau werkten. De onderbenutting van instromende schoolverlaters is in deze sector behoorlijk gedaald. In I999 gaf nog ruim $20 \%$ van de instromers aan een baan te hebben waarvoor een lagere opleiding vereist was dan het opleidingsniveau dat ze hadden. In de metaalproductensector en in de sector elektrotechniek is er sprake van een omgekeerde ontwikkeling: de onderbenutting steeg in deze sectoren tussen 1999 en 2004 aanzienlijk. In 2004 bedroeg de onderbenutting in de machine-industrie en de transportmiddelensector respectievelijk $24 \%$ en $39 \%$. Er is in deze sectoren geen sprake van grote verschuivingen in de onderbenutting van de ingestroomde schoolverlaters. Wat betreft de onderbenutting van de instroom scoort de metaal en elektrotechnische sector in vergelijking met andere sectoren in de indu- 
strie redelijk goed. Alleen in de elektrotechniek is de onderbenutting relatief hoog (47\% in 2004). In de meeste andere sectoren in de metaal en elektrotechnische sector is de onderbenutting lager dan in de voedingssector en de overige industrie.

\section{Figuur 4.8}

Aansluiting tussen opleiding en baan, 1999 en 2004, (in \% van totaal aantal schoolverlaters)

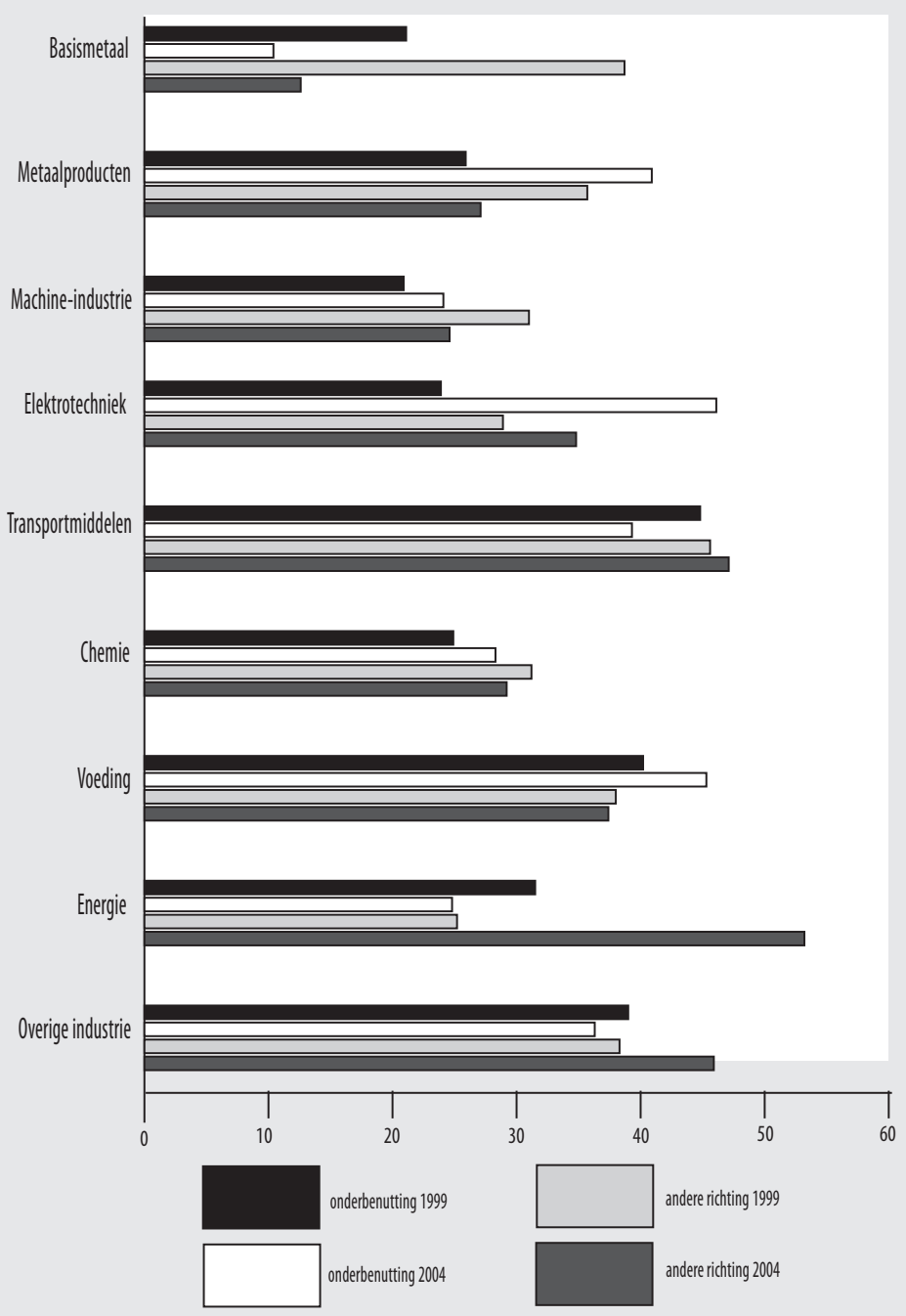

Bron: ROA schoolverlatersinformatiesysteem 1999 en 2004

Ook wat betreft de aansluiting naar opleidingsrichting scoort de metaal en elektrotechnische sector relatief goed. Alleen in de transportmiddelensector werken relatief veel schoolverlaters buiten hun eigen opleidingsrichting. In alle overige sectoren 
binnen de metaal en elektrotechnische sector is de aansluiting naar opleidingsrichting beter dan in de voedingssector, de sector energie en de overige industrie. In de basismetaal, de metaalproductensector en de machine-industrie is de aansluiting naar opleidingsrichting de laatste jaren behoorlijk verbeterd. In de elektrotechniek en de transportmiddelenindustrie was er in 2004 daarentegen sprake van een minder goede aansluiting naar opleidingsrichting dan in 1999.

\subsection{Ontbrekende competenties van schoolverlaters en de rol van het onderwijs}

De bedrijven die schoolverlaters in dienst nemen krijgen werknemers die hun kennis en vaardigheden vooral tijdens hun opleiding hebben aangeleerd. Het is de vraag of de metalektrobedrijven tevreden zijn met het competentieniveau van schoolverlaters. Om hier inzicht in te krijgen is de bedrijven gevraagd om aan te geven aan welke competenties het onderwijs in de toekomst volgens hen meer aandacht zou moeten besteden.

Uit figuur 4.9 komt duidelijk naar voren dat veel bedrijven de ontwikkeling van meer vaktechnische competenties cruciaal vinden: bijna $70 \%$ van de bedrijven vindt dat het onderwijs in de toekomst nog meer aandacht moet gaan besteden aan de vaktechnische vaardigheden.

Ook vindt een ruime meerderheid van de bedrijven (59\%) dat het onderwijsveld in de komende jaren meer aandacht moet gaan besteden aan het ontwikkelen van het probleemoplossend vermogen. Toch blijkt dit niet bij alle bedrijven in dezelfde mate het geval te zijn. Een personeelsmanager van een bedrijf dat vooral middelbaar en hoger opgeleide schoolverlaters in dienst neemt: "Probleemoplossend vermogen is meestal wel voldoende aanwezig, dat hebben ze wel voldoende". Bij een ander bedrijf, waar veel laagopgeleid personeel werkt, ziet de personeelsfunctionaris het anders: "Schoolverlaters missen nog wel eens het vermogen om probleemoplossend bezig te zijn, maar of de scholen daar nu veel aan kunnen doen, dat betwijfel ik. Probleemoplossend vermogen leer je volgens mij vooral in de praktijk".

Ook flexibiliteit en communicatieve vaardigheden zouden volgens heel wat bedrijven meer aandacht verdienen: $39 \%$ van de bedrijven in de Metalektro vindt dat scholen er in de toekomst meer oog voor moeten hebben dat ze de leerlingen ook flexibiliteit aanleren, terwijl $38 \%$ van de bedrijven vindt dat de ontwikkeling van communicatief vermogen tijdens de opleiding meer aandacht verdient. Sommige bedrijven stellen in dat verband wel een belangrijke voorwaarde, zo bleek uit de gehouden interviews. Een HRM-manager: "Communicatie is essentieel, en daarom mogen scholen daar best wat meer aandacht aan gaan besteden. Maar het mag niet ten koste gaan van de vaktechnische vaardigheden".

Circa een derde van de bedrijven geeft aan dat het onderwijs zich meer moet gaan richten op het ontwikkelen van die vaardigheden die er toe bijdragen dat werknemers 
zelfstandig kunnen werken. Bijna 30\% van de bedrijven in de Metalektro vindt dat scholen tijdens de opleidingen meer aandacht moeten gaan besteden aan het ontwikkelen van initiatief, het kunnen omgaan met veranderingen en het procesgericht kunnen werken.

\section{Figuur 4.9}

Competenties waar scholen volgens de metalektobedrijven in de toekomst meer aandacht aan zouden moeten besteden, 2005 (\% bedrijven)

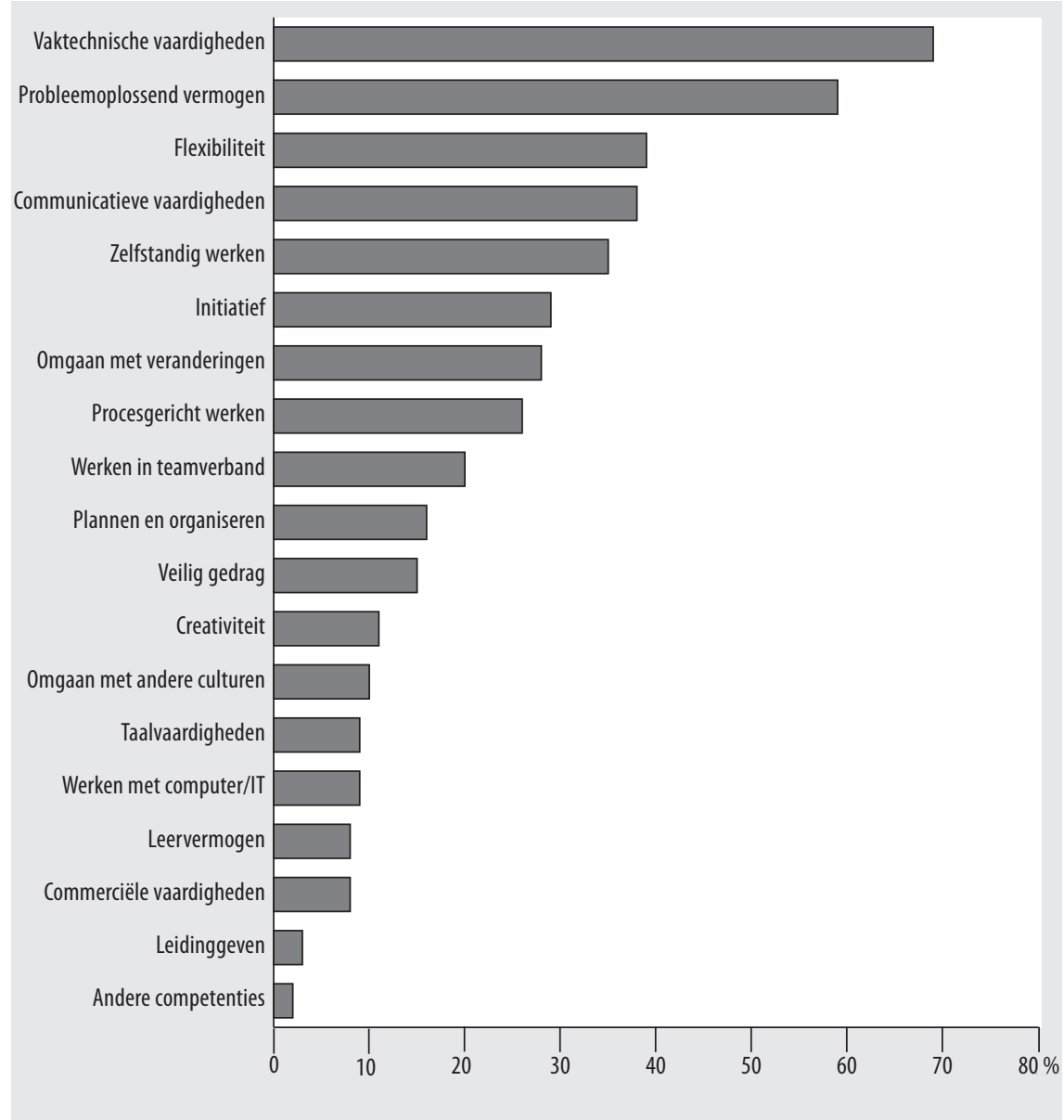

Bron: ROA/Werkgeverspanel Metalektro 2005

Voor de overige in figuur 4.9 genoemde competenties vinden telkens slechts enkele bedrijven dat er tijdens de opleiding meer aandacht aan moet worden besteed. Het gaat dan om het kunnen werken in teamverband (20\%), het kunnen plannen en organiseren ( $16 \%)$, veilig gedrag ( $15 \%)$, creativiteit (II\%), het kunnen omgaan met andere culturen (IO\%), taalvaardigheid (9\%), werken met IT (9\%), leervermogen $(8 \%)$, 
commerciële vaardigheden (8\%), en het kunnen leidinggeven (3\%). Dat relatief weinig bedrijven vinden dat de scholen meer aandacht moeten besteden aan de ontwikkeling van deze competenties kan verschillende oorzaken hebben. Enerzijds zouden de bedrijven er de voorkeur aan kunnen geven dat deze competenties op informele wijze tijdens het werk worden aangeleerd, bijvoorbeeld door 'learning-by-doing' of doordat startende schoolverlaters deze competenties beter kunnen ontwikkelen tijdens een coachingstraject. Anderzijds zijn een aantal competenties sterk gerelateerd aan de persoonlijkheid van werknemers, en is het de vraag of deze competenties wel ontwikkeld kunnen worden en op welke manier dat dan zou moeten gebeuren. Tenslotte is voor IT-vaardigheden de 'houdbaarheid van kennis' een mogelijke reden voor het feit dat de meeste bedrijven vinden dat scholen er de komende tijd geen extra aandacht aan moeten besteden. Deze competenties verouderen vaak zo snel dat ze het beste op continue basis on-the-job aangeleerd kunnen worden.

Sommige bedrijven in de Metalektro waarmee interviews zijn gehouden gaven tijdens de interviews aan dat ze de kennis en vaardigheden van schoolverlaters wel voldoende vinden, maar benadrukken dat het nogal eens mankeert aan de juiste werkhouding. Een personeelsfunctionaris: "Ze kunnen nog niet omgaan met het werkritme en hebben een 'vrijheid-blijheid' mentaliteit. We proberen dat zo snel mogelijk te veranderen. Lukt dat binnen een maand niet, dan vliegen ze eruit". Een ander bedrijf heeft het over "een houding die nog te studentikoos is". Een derde bedrijf vindt daarentegen dat schoolverlaters vaak wél kennistekorten hebben: "Het is nog niet eens zozeer de voor de functie benodigde vakkennis, die is er meestal wel. Wat we missen is een stukje kennis en ervaring over wat er buiten het bedrijf allemaal mogelijk is. Dat hebben ze voor hun eigen functie niet direct nodig, maar het is wel erg handig als ze ook enig inzicht hebben in de mogelijkheden die buiten de eigen functie aanwezig zijn”. 



\section{Scholing, inzetbaarheid en de loopbaan}

"De ontwikkelingen die op ons afkomen vragen om een goed geschoold personeelsbestand en daarom is ons personeel continu bezig met het updaten van de technische vakkennis."

"Materiaaltechnische kennis ontbreekt nogal eens, en omdat de enige Nederlandse opleiding die daarvoor bestond in Nederland gesloten is, organiseren we die cursussen nu zelf."

"Ook informeel leren is erg belangrijk. We denken dat formeel leren informeel leren kan versterken."

"Onze buitenlandse eigenaars zien het belang van opleiden niet genoeg, omdat ze te veel gericht zijn op kostenbesparingen en korte-termijn planning."

"Opleiden is bij ons een gedeelde verantwoordelijkheid, wij betalen en de werknemers investeren een stukje eigen tijd."

"Er moet altijd sprake zijn van een balans tussen de ontwikkeling van het individu en de prestaties van de organisatie."

"We scholen het personeel niet alleen voor de huidige functie, maar ook voor hun verdere loopbaan".

"Doordat we zoveel opleiden is het soms lastig de productietargets te halen".

"Flexibele inzet van personeel draagt ook bij tot de ontwikkeling van competenties."

"Meer kennis betekent beter inzetbaar personeel"

"De mobiliteit is bij ons nog veel te laag."

"Met opleiden alleen ben je er niet: Ook goede doorgroeimogelijkheden, zowel binnen als buiten de functies, zijn van groot belang." 
"Als er in mijn bedrijf net zoveel aandacht zou zijn voor mensen als voor machines, dan was mijn taak een stuk gemakkelijker. Bij machines wordt er echt gerend wanneer er iets kapot is, terwijl het veel langer duurt voordat een kennistekort van een werknemer wordt opgelost."

In dit hoofdstuk staan scholing, de flexibele inzetbaarheid en mobiliteit centraal. We beginnen met een overzicht van de ontwikkeling van de scholingsinspanningen in de Metalektro van de afgelopen jaren. Daarbij kijken we naar hoeveel er opgeleid wordt en welke cursussen er zoal gevolgd worden. Vervolgens gaan we in op het investeringsaspect van cursussen en trainingen: Wie betaalt de kosten en in wiens tijd worden cursussen en trainingen gevolgd. Daarna wordt er ingegaan op opleidingsdoelen en belemmeringen die optreden bij het realiseren van opleidingsinspanningen. Omdat opleiden lang niet altijd op formele wijze hoeft plaats te vinden kijken we vervolgens ook naar de rol die de brede inzetbaarheid van het personeel speelt bij de ontwikkeling van competenties. Opleiden staat vaak in het teken van de loopbaan. In het laatste gedeelte van dit hoofdstuk kijken we daarom naar de mate waarin het personeel in de metalektrobedrijven loopbaanstappen zet en in hoeverre het daarbij gaat om opwaartse mobiliteit, horizontale mobiliteit of demotie. 


\subsection{Scholingsdeelname in de Metalektro}

Ook in 2005 blijft het opleiden van het technisch personeel in de Metalektro een belangrijke prioriteit voor veel bedrijven. Uit figuur 5.I blijkt dat in 2005 in $77 \%$ van de bedrijven personeel intern wordt opgeleid, terwijl $86 \%$ van de bedrijven het technisch personeel externe cursussen of trainingen aanbiedt. Het is opvallend dat de ontwikkeling in de jaren 2002-2004, waarin er steeds meer intern wordt opgeleid, zich in 2005 niet heeft doorgezet. In 2005 gingen de metalektrobedrijven juist weer meer extern opleiden, terwijl de interne cursusparticipatie daalde van $8 \mathrm{I} \%$ in 2004 naar $77 \%$ in 2005 .

\section{Figuur 5.1}

Interne en externe cursusparticipatie in 2002-2005 (\% bedrijven)

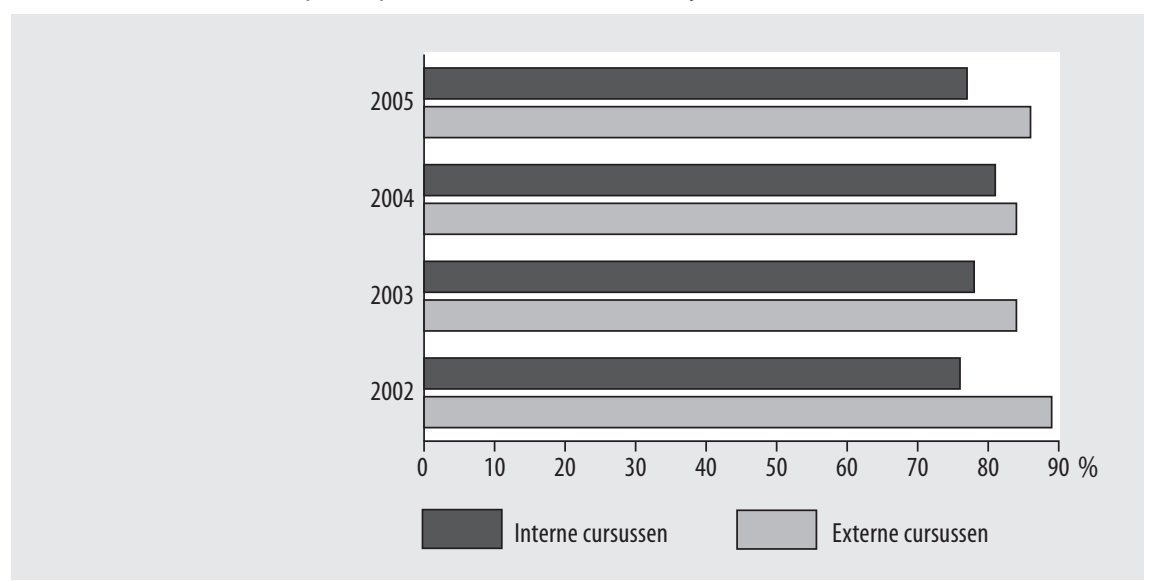

Bron: ROA/Werkgeverspanel Metalektro 2002-2005

Veel bedrijven bieden hun technisch personeel dus opleidingen en cursussen aan. Maar om hoeveel werknemers gaat het dan? Figuur 5.2 geeft een overzicht van de ontwikkeling van de interne en de externe cursusparticipatie van het technisch personeel in de Metalektro. In 2005 nam I7\% van het technisch personeel in de Metalektro deel aan interne cursussen of trainingen, terwijl $\mathrm{II} \%$ een externe cursus of training volgde. Uit de vergelijking met de jaren 2002-2004 blijkt dat de in 2004 ingezette afname van de trainingsparticipatie zich ook in 2005 heeft doorgezet. De deelname aan interne cursussen daalde echter minder sterk dan de deelname aan externe cursussen of trainingen. Het feit dat meer bedrijven hun personeel in 2005 externe cursussen aanbood, terwijl de externe cursusparticipatie van werknemers daalde, duidt erop dat in 2005 de externe opleidingsinspanningen gericht waren op een kleinere groep werknemers dan in het jaar daarvoor. 
Figuur $\mathbf{5 . 2}$

Interne en externe cursusparticipatie in 2002-2005 (\% werknemers)

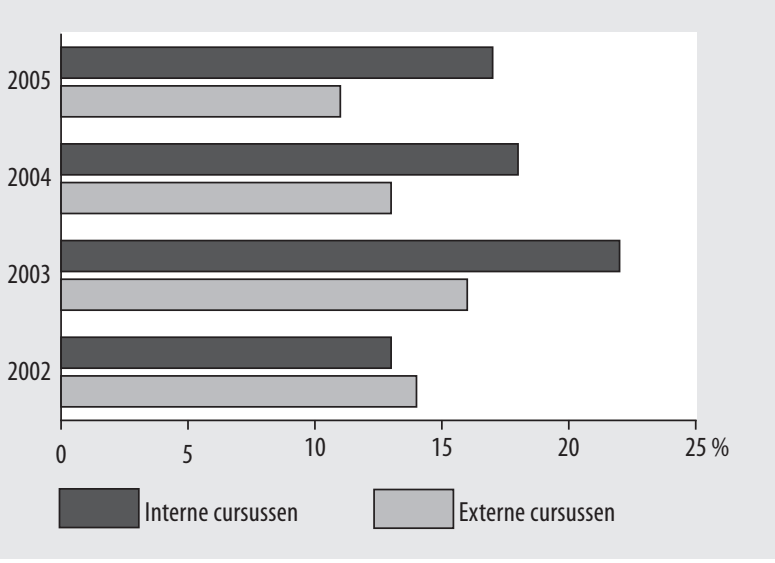

Bron: ROA/Werkgeverspanel Metalektro 2002-2005

\subsection{Soorten cursussen en trainingen}

Op welke terreinen volgt het technisch personeel cursussen? Figuur 5.3 laat zien dat het vooral gaat om trainingen en cursussen waarin het verbeteren van de vaktechnische vaardigheden centraal staat. In maar liefst $87 \%$ van de bedrijven waarin het technisch personeel op vaktechnisch gebied wordt bijgeschoold, biedt men het personeel interne cursussen aan. In $82 \%$ van de bedrijven volgt het personeel externe cursussen en trainingen die vaktechnisch van aard zijn. Sommige bedrijven hebben specifieke redenen om hun personeel interne vaktechnische cursussen of trainingen aan te bieden. Een personeelsfunctionaris: "Materiaaltechnische kennis ontbreekt nogal eens, zowel bij schoolverlaters als bij mensen met werkervaring. De enige opleiding die daarvoor bestond in Nederland is gesloten dus nu organiseren we die cursussen zelf. Soms halen we een deskundige uit het buitenland erbij die het een en ander nog eens goed verduidelijkt".

Ook volgt het personeel in nogal wat metalektrobedrijven cursussen en trainingen die gericht zijn op het stimuleren van veilig gedrag. In $42 \%$ van de bedrijven gebeurt dat intern, terwijl $26 \%$ van de bedrijven het technisch personeel externe cursussen of trainingen veilig gedrag aanbied.

Een derde belangrijk terrein waarop bedrijven hun personeel verder scholen heeft betrekking op IT cursussen of trainingen. Bijna 40\% van de bedrijven in de Metalektro laat het technisch personeel extern georganiseerde informaticacursussen volgen, terwijl $28 \%$ van de bedrijven het personeel informatiecursussen aanbiedt die intern georganiseerd worden. 
Enkele andere cursussen die in relatief veel bedrijven gevolgd worden zijn trainingen voor leidinggeven ( $26 \%$ intern, $38 \%$ extern), cursussen procesgericht werken $(25 \%$ intern, $16 \%$ extern) en communicatietrainingen ( $24 \%$ intern, I $8 \%$ extern). Verder volgt het technisch personeel in $23 \%$ van de bedrijven intern georganiseerde cursussen die gericht zijn op het verbeteren van hun probleemoplossend vermogen, terwijl dergelijke cursussen in $16 \%$ van de bedrijven extern worden georganiseerd.

Figuur 5.3

Interne en externe cursusparticipatie van het technisch personeel, 2005 (\% bedrijven)

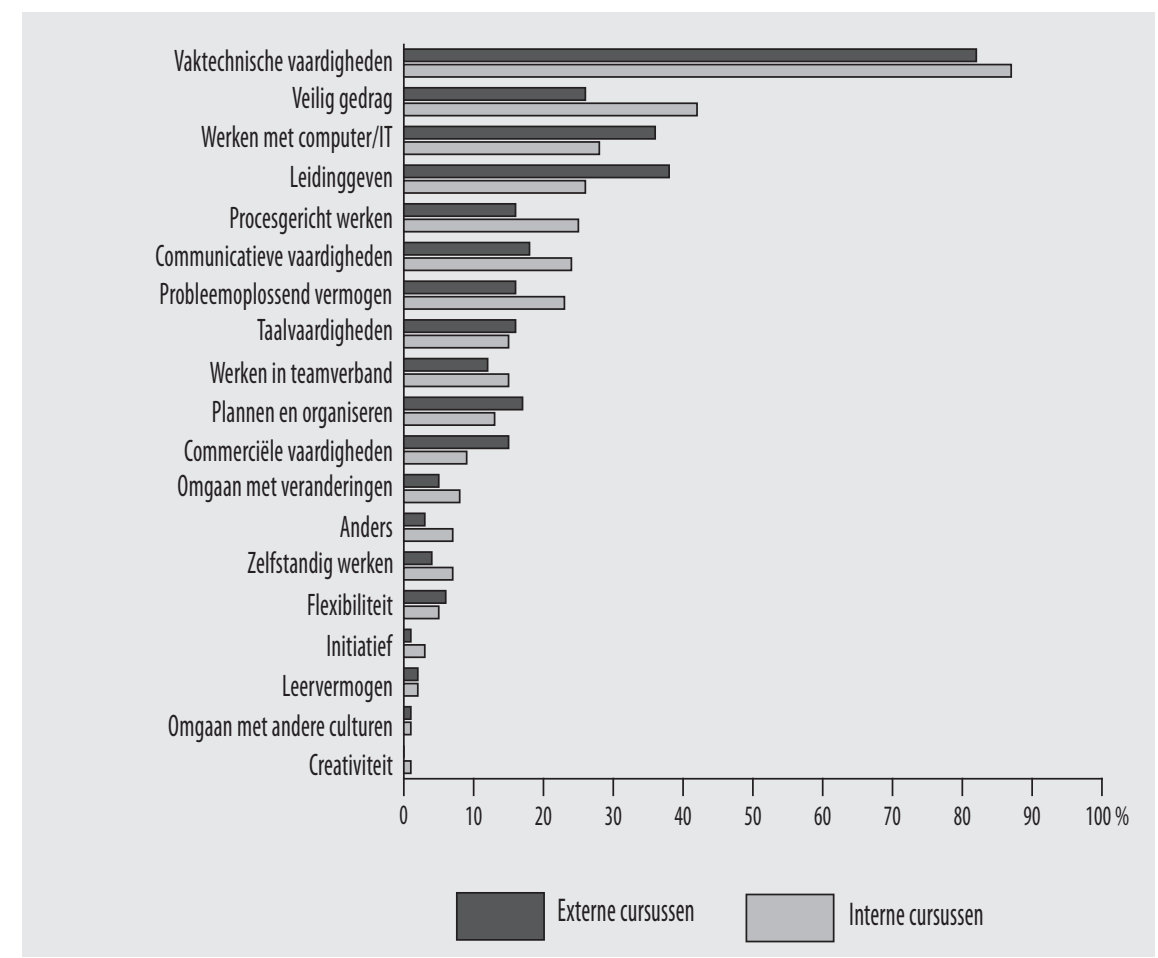

Bron: ROA/Werkgeverspanel Metalektro 2005

De in 2004 gelanceerde POFI-agenda blijkt nog weinig invloed te hebben op de scholingsparticipatie van het technisch personeel. De deelname aan cursussen gericht op het omgaan met verandering, flexibiliteit en initiatief is in 2005 niet groter dan in 2004. Zoals in de Arbeidsmarktmonitor Metalektro 2004 al werd aangegeven, zullen deze competenties dan ook vooral door informele leerprocessen moeten worden ontwikkeld. Cursussen waarbij het vergroten van het probleemoplossend vermogen centraal staat zijn daarentegen wel wat belangrijker geworden dan een jaar geleden, vooral wat betreft extern georganiseerde cursussen. In 2004 volgde in IO\% van de bedrijven het personeel dergelijke cursussen, terwijl in $200516 \%$ van de bedrijven het personeel extern georganiseerde cursussen aanbied waarbij het verbeteren van het probleemoplossend vermogen centraal staat. 
Uit de interviews met bedrijven die aan het werkgeverspanel Metalektro deelnemen blijkt veel bedrijven naast formele cursussen en trainingen ook veel waarde hechten aan informeel leren. Een bedrijf in de elektrotechniek: "Informeel leren vindt veel bij ons plaats. Het is duidelijk dat de interesse van de medewerkers een prominente rol speelt bij informeel leren. Vaak zorgt de interesse van medewerkers ervoor dat ze na het volgen van een cursus (de 'basisinstructie') meer willen weten over een bepaalde machine of proces. Die kennis verwerven ze dan via collega's, hun chef of ze duiken zelf de boeken in". Ook het gewenste gedrag in takkgroepen wordt veelal informeel aangeleerd: "Samenwerking, functioneren en jezelf kunnen handhaven, dat leren de mensen hier vooral tijdens hun werk". Maar ook zelfstandigheid is iets dat informeel wordt aangeleerd: "We stellen het nu overigens ook veel meer op prijs als een werknemer zich zelfstandig opstelt. De cultuur van 'zeg maar wat ik moet doen' heeft lang overheerst maar daar moeten we vanaf".

Over de wisselwerking tussen formeel en informeel leren zijn veel bedrijven positief. Een HRM-manager: "We denken dat formeel leren informeel leren kan versterken. We maken voor iedereen in ons bedrijf een formeel opleidingsplan waarin we cursussen plannen. Je ziet vaak dat mensen na het volgen van een cursus uit zichzelf op informele manieren verder gaan leren. Op die manier wordt er heel wat kennis opgedaan".

\subsection{Investeren in opleiden}

Wie investeert er tijd en geld in de cursussen voor het technisch personeel? Uit figuur 5.4 blijkt dat in 2005 cursussen in $55 \%$ van de bedrijven in de tijd van het bedrijf plaatsvinden. In $26 \%$ van de bedrijven volgt het technisch personeel daarentegen cursussen in de eigen tijd. In $19 \%$ van de metalektrobedrijven vinden de cursussen en trainingen gedeeltelijk in de tijd van het bedrijf en gedeeltelijk in de eigen tijd van de werknemers plaats. Uit de vergelijking met 2003 en 2004 komt naar voren dat er twee ontwikkelingen plaatsvinden. Allereerst is het aantal bedrijven waarbij er sprake is van een door werknemers en bedrijven gedeelde tijdsinvestering gedaald. Het aantal bedrijven waarin het personeel de cursussen geheel in de eigen tijd volgt is daarentegen aanzienlijk gestegen van $17 \%$ in 2003 tot $26 \%$ in 2005 . 


\section{Figuur 5.4}

Tijdsinvestering bij cursusdeelname door het technisch personeel, 2003-2005

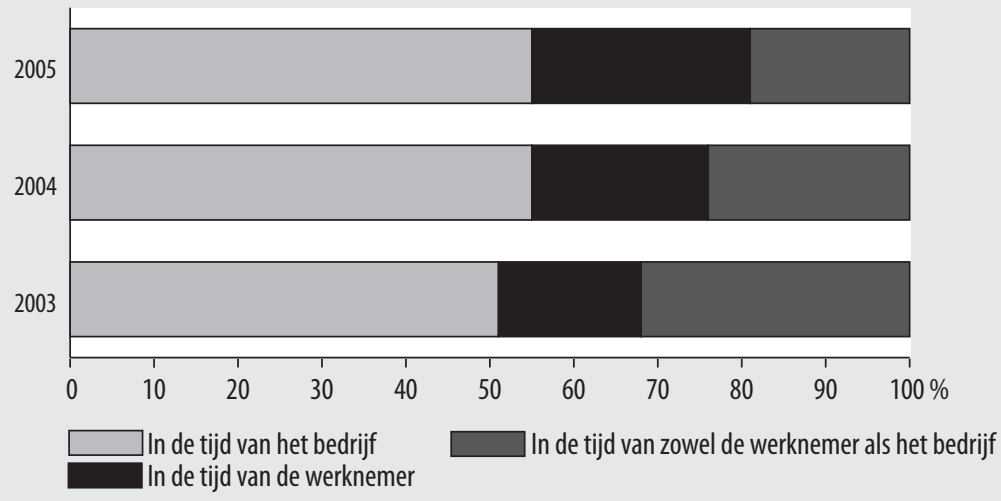

Bron: ROA/Werkgeverspanel Metalektro 2003-2005

Hoeveel geld investeert de Metalektro in de cursussen en trainingen van het technisch personeel dat werkzaam is in de sector? Figuur 5.5 laat zien dat de gemiddelde "out-of-pocket" kosten in 2005 circa $€ 45.000$ per bedrijf bedragen. Dit betekent dat de opleidingsinvesteringen ten opzichte van het jaar ervoor iets gestegen zijn. De investeringen zijn echter nog steeds beduidend lager dan in 2003, toen de metalektrobedrijven nog gemiddeld $€ 65.000$ aan cursussen en trainingen voor hun technisch personeel uitgaven.

\section{Figuur 5.5}

Gemiddelde totale (out of pocket) kosten voor cursussen van het technisch personeel, 2003-2005 (€ per bedrijf)

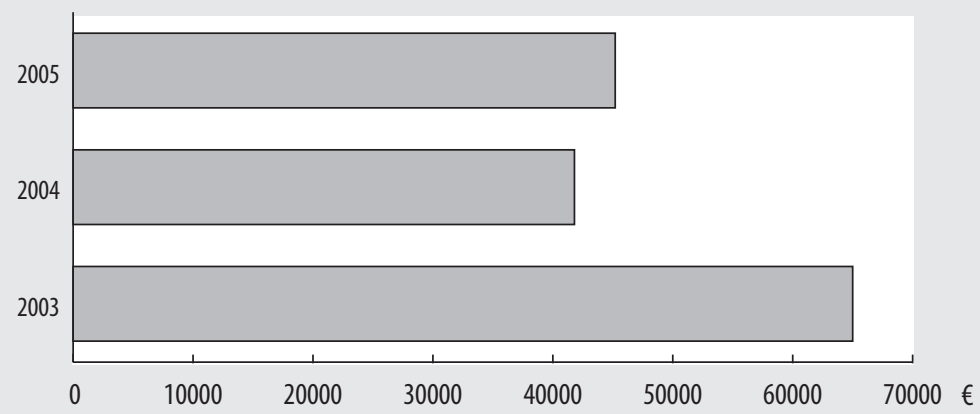


Ook relatief gezien bleven de opleidingsinvesteringen in de Metalektro in 2005 op peil. Evenals in 2004 geven de bedrijven in de Metalektro in 2005 gemiddeld 3\% van de loonsom uit aan cursussen en trainingen voor hun technisch personeel.

Hoeveel bedroegen de opleidingsinvesteringen per getrainde werknemer? In 2005 ging het om een bedrag van circa $€$ I.3OO (zie figuur 5.6). Dit houdt in dat de opleidingsinvesteringen per getrainde werknemer verder zijn gedaald. Dat de gemiddelde investeringen per werknemer afnamen, terwijl de totale uitgaven op peil bleven, betekent dat de opleidingsuitgaven in 2005 over meer werknemers worden gespreid dan in de jaren daarvoor. Dit wijst er op dat metalektrobedrijven hun scholingsbeleid zijn gaan verbreden.

\section{Figuur 5.6}

Gemiddelde totale (out of pocket) kosten voor cursussen van het technisch personeel, 2003-2005 ( $€$ per getrainde werknemer)

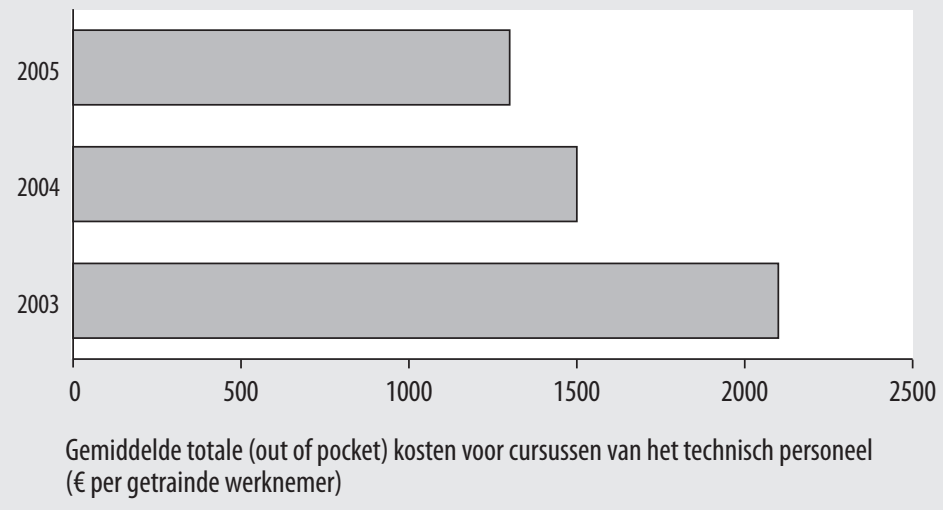

Bron: ROA/Werkgeverspanel Metalektro 2003-2005

Ondanks het feit dat er behoorlijk geïnvesteerd wordt in het personeel in de Metalektro, zijn niet alle bedrijven even tevreden over de omvang van hun opleidingsinspanningen. Uit gesprekken met bedrijven blijkt dat dit verschillende redenen kan hebben. Een metalektrobedrijf dat in handen is van een groter buitenlands concern ziet de eigen wensen nog wel eens botsen met die van de buitenlandse eigenaars: "Ze zien het belang van een goede opleidingsstrategie niet in en zijn veel te veel gericht op kostenbesparingen. Ik denk dat onze eigenaars te korte-termijn gericht denken en volgens mij hebben ze nog nooit gehoord van een planning die langer is dan een jaar". Een ander bedrijf vindt dat de HRM-afdeling zich te veel moet bezighouden met allerlei wettelijke regelingen: "Dat vergt een hele investering, en dat geld zouden we beter kunnen gebruiken voor opleidingen”.

Wie betaalt de kosten van het opleiden van het technisch personeel? Figuur 5.7 laat zien dat het overgrote deel van de opleidingskosten (9I\%) gedragen wordt door de 
metalektrobedrijven. Het overige deel van de kosten wordt door de werknemers bekostigd, of door de subsidies van de Stichting A+O of ESF. Het is opvallend dat de bijdrage van de Stichting $\mathrm{A}+\mathrm{O}$ flink is gedaald ten opzichte van een jaar geleden: Van $22 \%$ in 2004 naar $5 \%$ in 2005. Dit weerspiegelt de nieuwe koers die de Stichting A+O in 2005 is gaan varen. Daarbij is er veel meer aandacht voor het bieden van ondersteuning aan bedrijven, terwijl het geven van opleidingssubsidies minder belangrijk is geworden. Geconstateerd kan worden dat dit niet heeft geleid tot een daling van de scholingsuitgaven ten opzichte van het voorgaande jaar.

Figuur 5.7

Directe kosten voor cursussen van het technisch personeel dat bekostigd wordt door bedrijf, werknemer of andere partijen, 2005 (\% kosten)
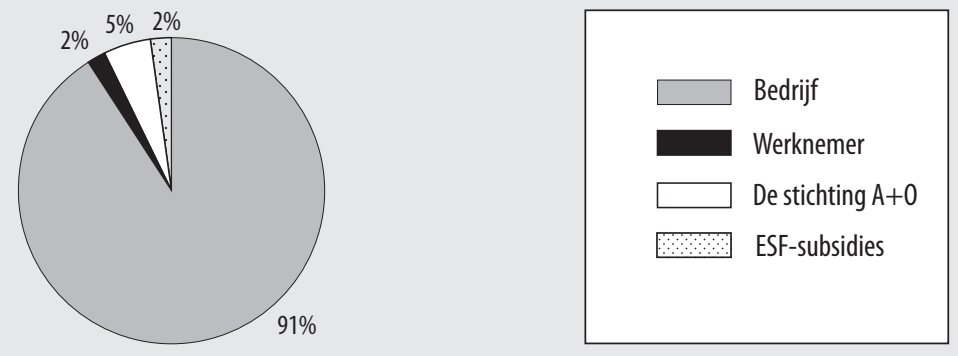

Bron: ROA/Werkgeverspanel Metalektro 2005

De bedrijven die meededen aan de interviews vinden dat zowel het bedrijf als de medewerker verantwoordelijk zijn voor het investeren in cursussen en trainingen. Een personeelsmanager: "Opleiden is bij ons een gedeelde verantwoordelijkheid, maar we kijken per geval wat redelijk is. Meestal komt het erop neer dat wij de kosten dragen terwijl werknemers wat van hun eigen tijd investeren". Sommige bedrijven zijn wat stelliger over de verantwoordelijkheid van werknemers op dit punt dan andere. Een bedrijf met relatief veel laagopgeleid personeel vraagt dat het personeel wel wat eigen tijd investeert, maar dat is volgens eigen zeggen "nooit echt veel". Cursussen op zaterdag worden in dit bedrijf ook beschouwd als overwerk en dus uitbetaald. Een ander bedrijf ziet dat anders: "We betalen de cursussen, maar we verlangen ook een uitdrukkelijke tijdsinvestering van de werknemers zelf." Een derde bedrijf benadrukt dat de gedeelde verantwoordelijkheid op het vlak van de opleidingsinvesteringen ook betekent dat zowel het bedrijf als de werknemers van scholing moeten profiteren: "Er moet altijd sprake zijn van een balans tussen de ontwikkeling van het individu en de prestaties van de organisatie". 


\subsection{Opleidingsdoelen en belemmeringen}

Welke doelen hebben de bedrijven voor ogen wanneer ze hun technisch personeel cursussen of trainingen laten volgen? Figuur 5.8 laat zien dat de metalektrobedrijven het verbeteren van bestaande vaardigheden in de functie het belangrijkste doel vinden. Ruim $80 \%$ van de bedrijven geeft aan hun technisch personeel met dit doel te scholen. Ook het aanleren van nieuwe vaardigheden voor de huidige functie wordt door een ruime meerderheid van de bedrijven (67\%) als een belangrijk opleidingsdoel gezien. De helft van de bedrijven probeert de inzetbaarheid te vergroten door het technisch personeel cursussen en trainingen te laten volgen, terwijl $40 \%$ van de bedrijven in opleidingen investeert om het technisch personeel nieuwe vaardigheden aan te leren voor hun verdere loopbaan. Al met al kan gesteld worden dat behoorlijk wat bedrijven in de Metalektro hun personeel niet alleen functiegericht opleiden, maar bij het investeren in hun technisch personeel ook een lange termijn visie hebben, waarin loopbaanontwikkeling en flexibele inzetbaarheid de sleutelbegrippen zijn.

\section{Figuur 5.8}

Doelen die een rol spelen bij de cursusdeelname van het technisch personeel, 2005 (\% bedrijven)

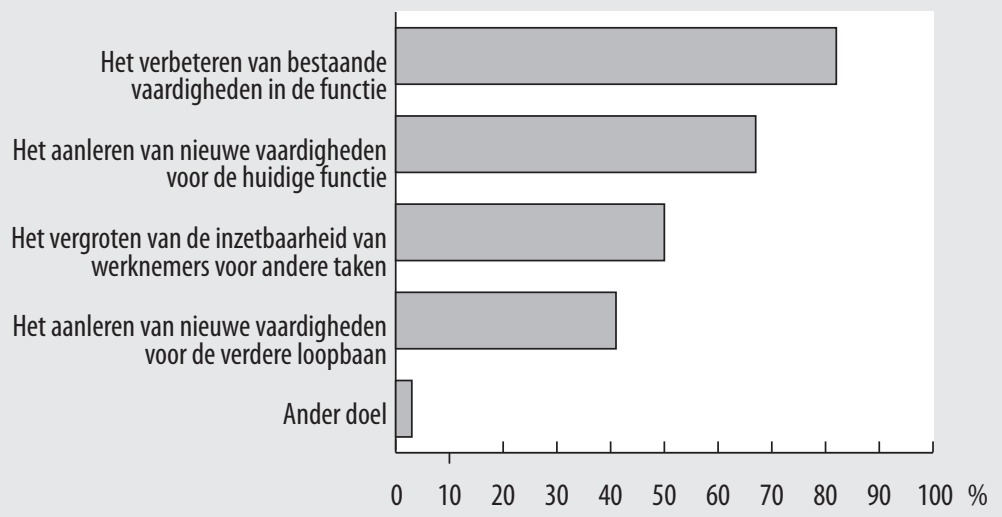

Bron: ROA/Werkgeverspanel Metalektro 2005

Uit de interviews met metalektrobedrijven blijkt dat bedrijven met het scholen van hun technisch personeel vaak verschillende doelen tegelijk nastreven maar dat er tussen bedrijven ook behoorlijke verschillen kunnen zijn. Een groot high-tech bedrijf: "De belangrijkste reden om mensen te scholen is het verbeteren van het functioneren in de huidige functie, maar we scholen mensen ook zodat ze loopbaanstappen kunnen zetten. Het gaat dan vooral om de ontwikkeling van de werknemers zelf, die door mobiliteit een steeds grotere toegevoegde waarde aan het bedrijf kunnen leveren. Op de derde plaats komt scholing in het kader van de inzetbaarheid. Die proberen we vooral te vergroten door scholing gericht op vakinhoudelijke kennis". Een ander 
bedrijf vindt ook dat scholing in de eerste plaats de vaardigheden in de huidige functie moet verbeteren: "Maar scholing in het kader van de loopbaan, dat komt bij ons niet zo vaak voor. Dat is echt iets voor individuele gevallen. Er komt wel eens iemand bovendrijven die echt goed is en die mensen bieden we dan een bepaald traject aan". Ze noemt twee voorbeelden: een LTS-MTS traject voor laaggeschoolde werknemers en een hoger opgeleide R\&D engineer, die momenteel wordt omgeschoold tot quality manager.

Een derde bedrijf heeft andere prioriteiten: "We scholen het personeel in de eerste plaats in het kader van de multitasking, de brede inzetbaarheid. We scholen ook wel om vaktechnische kennis bij te spijkeren of in het kader van de loopbaan van het personeel, maar dat is toch veel minder". Een bedrijf in de metaalproductenindustrie ziet het weer anders. De personeelsfunctionaris: "Als we personeel cursussen laten volgen, dan doen we dat hoofdzakelijk in het kader van de loopbaan". Hij vertelt dat dat meestal gebeurt wanneer goede werknemers die in hogere functies terechtkomen, achteraf blijken bepaalde kennis te missen. "Op dat moment gaan we scholen, en de cursussen zijn heel uiteenlopend. Van vakkennis tot verkoopopleidingen. We scholen dus pas op het moment dat iemand de kennis echt nodig heeft".

Kunnen de bedrijven de opleidingsdoelen die ze zichzelf stellen gemakkelijk realiseren? Figuur 5.9 geeft een overzicht van de belemmeringen die metalektrobedrijven ervaren bij het realiseren van de cursusdeelname van hun technisch personeel. Evenals in 2004 blijkt dat bijna de helft van de bedrijven geen belemmeringen heeft ervaren bij het realiseren van de opleidingsdoelen. Dit betekent echter ook dat meer dan de helft van de metalektrobedrijven wel belemmeringen ondervindt bij het opleidingsbeleid. Ruim $20 \%$ van de bedrijven vindt dat cursussen te veel tijd in beslag nemen of te veel kosten. De vervanging van diegenen die een opleiding volgen vormt voor I $8 \%$ van de bedrijven een belemmerende factor. Een personeelsfunctionaris waarmee een interview gehouden werd bevestigt dit: "Gemiddeld is $5 \%$ van ons productiepersoneel bezig met een cursus en daarom is het wel eens lastig om de productietargets te halen". Daarnaast is het voor een aantal bedrijven moeilijk om de opleidingsdoelen te realiseren omdat hun technisch personeel er onvoldoende in is geïnteresseerd of omdat de cursussen die ze hun personeel zouden willen laten volgen niet worden aangeboden in de regio waar het bedrijf gevestigd is. Enkele bedrijven geven aan dat de beschikbare cursussen niet aansluiten bij het kennisniveau van het personeel. Een HRM-manager van een bedrijf met relatief veel laaggeschoolde arbeid vindt dit een groot probleem: "Bij niet alle werknemers is er sprake van voldoende leercapaciteiten. We hebben een aantal jaren lang geprobeerd een groep laaggeschoolde werknemers op te leiden met cursussen veilig werken, maar dat heeft niks opgeleverd. De mensen staken er gewoon niks van op".

Er zijn tussen 2004 en 2005 enkele opmerkelijke verschuivingen in de mate waarin bedrijven bepaalde factoren als belemmerend ervaren voor de cursusdeelname van het technisch personeel. Een positieve ontwikkeling is dat het aantal bedrijven dat vindt 
dat de beschikbare cursussen niet goed aansluiten bij de behoefte van het bedrijf is gedaald. Dit betekent dat bedrijven het in 2005 gemakkelijker vonden om cursussen te vinden die goed aansluiten bij hun eigen behoefte. Vervangingsproblemen zijn daarentegen in belang toegenomen, doordat de conjunctuur aantrekt en de bedrijfsdrukte weer wat toeneemt. Het is zorgelijk dat het percentage bedrijven dat vindt dat het technisch personeel niet geïnteresseerd is in cursussen in 2005 toegenomen is. Betrokkenheid en interesse bij opleidingen is namelijk een factor die het succes van de opleidingsinspanningen in grote mate bepaalt.

\section{Figuur 5.9}

Belemmeringen bij de cursusdeelname van het technisch personeel, 2004-2005 (\% bedrijven)

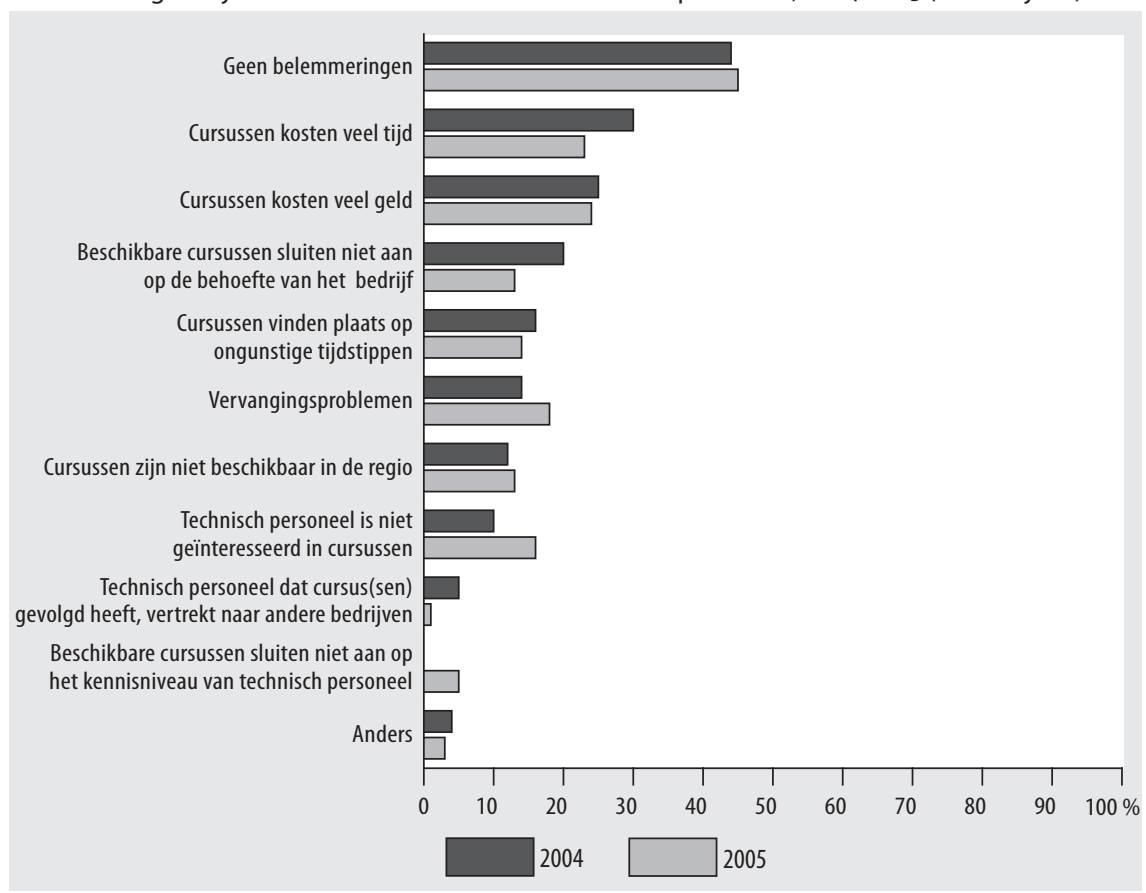

Bron: ROA/Werkgeverspanel Metalektro 2004-2005

\subsection{Brede inzetbaarheid}

Een personeelsmanager van een high-tech bedrijf benadrukt dat werknemers hun competenties ook ontwikkelen tijdens hun werk, bijvoorbeeld wanneer ze flexibel worden ingezet voor taken die niet direct tot hun eigen functie behoren: "We geloven heilig in blended learning. Trainingen en cursussen moeten sterk gerelateerd zijn aan en toegepast worden in de dagelijkse praktijk van het werk. Het leren van medewerkers is een optelsom van trainingen, informeel leren en leren door inzetbaarheid". Dat werpt echter wel de vraag op hoe het staat met de inzetbaarheid van het personeel in 
de Metalektro. Figuur 5.Io geeft een overzicht van de mate waarin het personeel in de metalektrosector breed inzetbaar is.

Figuur 5.10

Inzetbaarheid van het personeel per functiecategorie, 2005 (\% bedrijven)

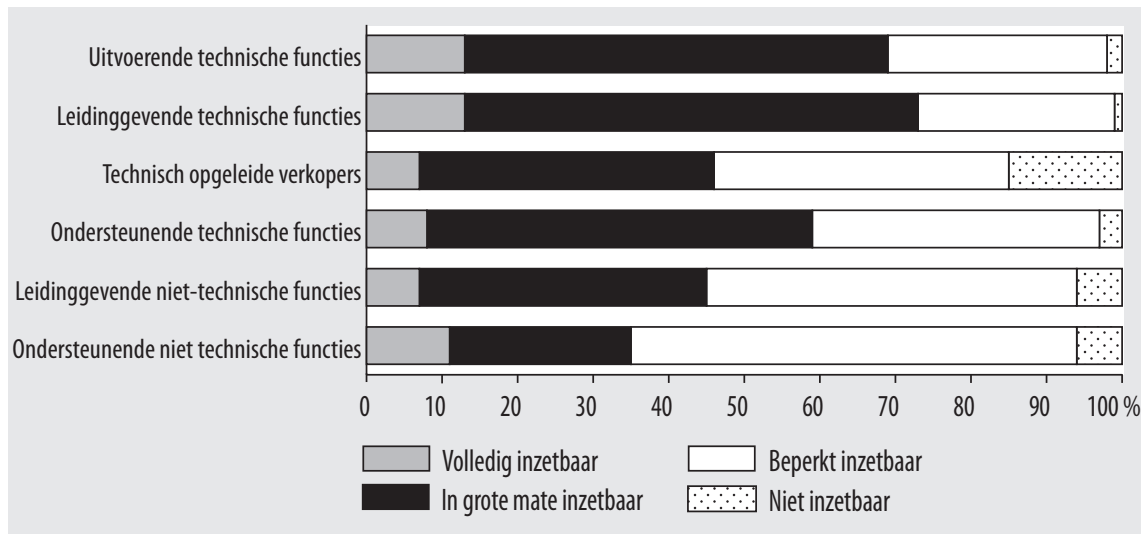

Bron: ROA/Werkgeverspanel Metalektro 2005

De inzetbaarheid is het grootst voor de uitvoerende en leidinggevende technici. Bijna $70 \%$ van de bedrijven vindt dat het uitvoerend technisch personeel breed inzetbaar is, terwijl circa driekwart van de bedrijven aangeeft dat het leidinggevende technisch personeel volledig of in grote mate breed inzetbaar is. Technisch opgeleide verkopers en niet-technisch leidinggevenden zijn daarentegen minder vaak breed inzetbaar. Meer dan de helft van de bedrijven vindt dat technisch opgeleide verkopers en niettechnisch leidinggevenden slechts beperkt of helemaal niet breed inzetbaar zijn. De ondersteunende technici zijn daarentegen wat beter inzetbaar: $8 \%$ van de bedrijven vindt het personeel in de ondersteunende technische functies volledig inzetbaar en $5 \mathrm{I} \%$ geeft aan dat ondersteunende technici in grote mate inzetbaar zijn. Het niettechnische ondersteunend personeel wordt door de metalektrobedrijven het minst inzetbaar gevonden: tweederde van de bedrijven vindt dat dit personeel niet of slechts beperkt inzetbaar is.

\section{Gebruik van inzetbaarheid}

Het is natuurlijk de vraag of de metalektrobedrijven ook daadwerkelijk gebruik maken van de inzetbaarheid van het personeel. Figuur 5.II laat zien dat er op dit punt grote verschillen zijn tussen de diverse functiecategorieën. In het algemeen wordt er het meest gebruik gemaakt van de inzetbaarheid van het uitvoerend technisch personeel. Maar liefst 95\% van de bedrijven makt vaak of af en toe gebruik van de inzetbaarheid van de uitvoerende technici. $56 \%$ van de bedrijven maakt af en toe gebruik van de inzetbaarheid van hun leidinggevende technici, terwijl bijna een kwart van de bedrijven dat zelfs vaak doet. Ook ondersteunende technici worden regelmatig 
flexibel ingezet: de helft van de bedrijven in de Metalektro zet het ondersteunend personeel af en toe flexibel in.

\section{Figuur 5.11}

Mate waarin bedrijven gebruik maken van de inzetbaarheid van het personeel per functiecategorie, 2005 (\% bedrijven)



Bron: ROA/Werkgeverspanel Metalektro 2005

Het personeel in de andere functies wordt veel minder vaak flexibel ingezet. Technisch opgeleide verkopers blijken het minst vaak flexibel te worden ingezet. Meer dan de helft van de bedrijven zet hun technisch opgeleide verkopers niet flexibel in. Deze lage benutting van de inzetbaarheid van de technisch opgeleide verkopers heeft er ook mee te maken dat verkoopfuncties zich minder goed lenen voor flexibele inzetbaarheid dan functies waarin de nadruk ligt op het gebruiken en toepassen van technisch kennis en vaardigheden. In veel bedrijven wordt er ook zelden of nooit gebruik gemaakt van de inzetbaarheid van het personeel in de leidinggevende en ondersteunende niet-technische functies.

\section{Welke competenties dragen bij aan de brede inzetbaarheid?}

Het breed inzetbaar zijn van het personeel staat natuurlijk niet los van de kennis en vaardigheden waarover ze beschikken. Een personeelsfunctionaris is daar stellig over: "Als mensen over meer soorten kennis beschikken, dan zijn ze beter op verschillende plaatsen in de organisatie inzetbaar". Een ander bedrijf: "Om de inzetbaarheid op peil te houden is het van groot belang dat de aandacht voor opleiden niet verslapt". Om de relatie tussen de competenties en de mate waarin het personeel inzetbaar is in kaart te brengen is er aan de bedrijven gevraagd in hoeverre het verbeteren van de competenties van het technisch personeel de inzetbaarheid stimuleert. Figuur 5.I2 geeft daarvan een overzicht. 
Het blijkt dat de inzetbaarheid van het personeel vooral gestimuleerd kan worden wanneer het probleemoplossend vermogen en de mate waarin iemand flexibel is versterkt wordt. De helft van de metalektrobedrijven vindt dat het verbeteren van deze competenties de inzetbaarheid van het technisch personeel sterk bevordert en vrijwel geen enkel bedrijf vindt dat het vergroten van probleemoplossend vermogen en de flexibiliteit van het personeel de inzetbaarheid niet stimuleert.

\section{Figuur 5.12}

Mate waarin verbetering van competenties van het technisch personeel de inzetbaarheid vergroot, 2005 (\% bedrijven)

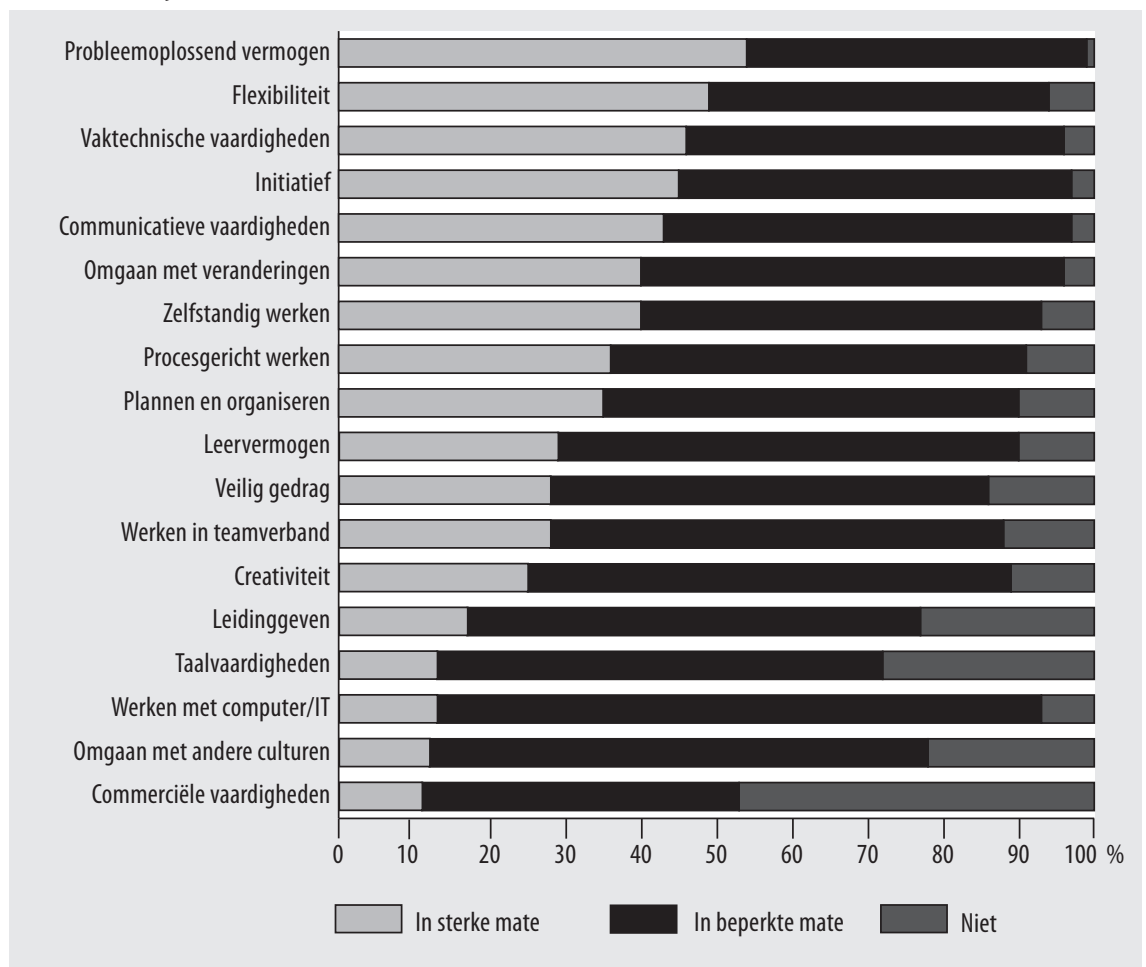

Bron: ROA/Werkgeverspanel Metalektro 2005

Andere competenties die de inzetbaarheid van het personeel in sterke mate kunnen bevorderen zijn goede vaktechnische vaardigheden, het kunnen nemen van initiatief, communicatieve vaardigheden, het omgaan met veranderingen en zelfstandig kunnen werken. Circa 40\% van de bedrijven vindt dat het verbeteren van deze competenties in sterke mate bijdraagt aan de inzetbaarheid van het personeel. De relatie met de inzetbaarheid is wat minder sterk voor het goed kunnen plannen en organiseren, het leervermogen, veilig gedrag, het werken in teamverband en iemands creativiteit. Maar ook hier vindt meer dan $80 \%$ van de bedrijven dat het verbeteren van deze competenties in sterke of in beperkte mate bijdraagt aan de inzetbaarheid van het tech- 
nisch personeel. Het kunnen leidinggeven en goede taalvaardigheden zijn volgens de bedrijven iets minder relevant voor de inzetbaarheid van het technisch personeel. Ruim $20 \%$ van de bedrijven vindt zelfs dat het verbeteren van deze competenties de inzetbaarheid van het technisch personeel niet stimuleert. Het beschikken over goede IT kennis en vaardigheden draagt daarentegen volgens ruim $90 \%$ van de bedrijven bij aan de inzetbaarheid van het technisch personeel. Wel vinden de meeste bedrijven dat er hier slechts sprake is van een beperkte invloed. Circa IO\% van de bedrijven vindt dat het verbeteren van de omgang met andere culturen of de commerciële vaardigheden de inzetbaarheid van het personeel in sterke mate bevordert. Het verbeteren van de omgang met andere culturen heeft volgens tweederde van de bedrijven echter slechts een beperkte invloed op de inzetbaarheid. Het verbeteren van de commerciële vaardigheden van het personeel is nog minder belangrijk voor de inzetbaarheid van het personeel, aangezien bijna de helft van de bedrijven aangeeft dat dit niet leidt tot een betere inzetbaarheid.

\subsection{Loopbanen in de Metalektro}

Het opleiden van het technisch personeel heeft, zoals we eerder zagen, in circa $40 \%$ van de bedrijven tot doel de loopbaanperspectieven te verbeteren. Met meer kennis en vaardigheden zijn werknemers immers beter toegerust om loopbaanstappen te zetten. Dit roept de vraag op in hoeverre er in de Metalektro sprake is van doorstroom van personeel van de ene naar de andere functie. Figuur 5.I3 laat zien dat circa de helft van de bedrijven in de Metalektro hun technisch personeel laat doorstromen. In $53 \%$ van de bedrijven blijven technici na een loopbaanstap in een technische functie werkzaam. De mobiliteit van technici naar andere technische functies is wat toegenomen: In 2004 was er nog in slechts $39 \%$ van de bedrijven sprake van loopbaanstappen naar andere technische functies. Ondanks deze stijging zijn niet alle bedrijven tevreden met het niveau van de mobiliteit van het technisch personeel in hun eigen bedrijf. Een personeelsmanager: "De mobiliteit is bij ons veel te laag. En als er sprake is van doorstroom dan is dat meestal gedwongen of vanwege demotie. Veel werknemers zijn bij ons nog onvoldoende gewend aan het idee dat mobiliteit gezond is".

Figuur 5.13

Doorstroom van technisch personeel, 2004-2005 (\% bedrijven)

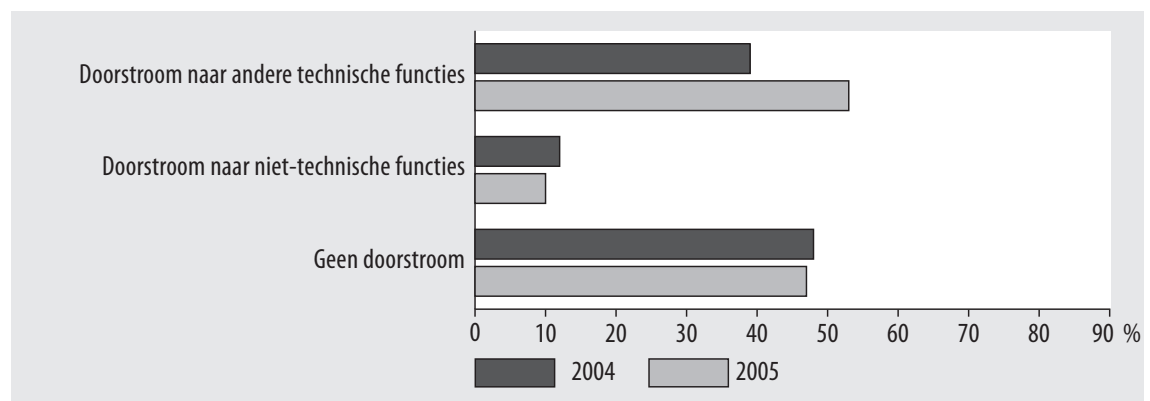

Bron: ROA/Werkgeverspanel Metalektro 2004-2005 
Loopbaanstappen van technisch personeel naar niet-technische functies komen veel minder vaak voor. In 2005 stroomde er in slechts IO\% van de bedrijven technisch personeel door naar een niet-technische functie. Deze vorm van mobiliteit is in 2005 ook wat afgenomen.

Naar welk functieniveau stromen de technische werknemers die een overstap maken naar een andere technische functie door? Uit figuur 5.I4 komt duidelijk naar voren dat het in de meeste gevallen gaat om loopbaanstappen naar functies van een hoger niveau. In bijna $70 \%$ van de bedrijven waarin technici doorstromen naar andere technische functies is er sprake van opwaartse mobiliteit. Maar ook 'horizontale' mobiliteit naar functies op hetzelfde niveau komt veelvuldig voor. In bijna $60 \%$ van de bedrijven stromen technici door naar andere technische functies op hetzelfde niveau. Loopbaanstappen van technisch personeel naar functies op een lager niveau komen relatief weinig voor. In 2005 was er in slechts $8 \%$ van de bedrijven met doorstroom sprake van zogenaamde "demotie". De doorstroom naar banen op een lager functieniveau is in 2005 in vergelijking met het jaar daarvoor ook iets afgenomen.

\section{Figuur 5.14}

Horizontale en verticale doorstroom naar technische functies, 2004-2005 (\% van de bedrijven met doorstroom)



Bron: ROA/Werkgeverspanel Metalektro 2004-2005

In hoeverre is er bij de doorstroom van technici die in een niet-technische functie gaan werken sprake van horizontale of verticale mobiliteit? Figuur 5.I5 laat zien dat er in 2005, in vergelijking met 2004, behoorlijke verschuivingen zijn opgetreden. Zo blijkt dat het aantal bedrijven waarin het technisch personeel doorstroomt naar niettechnische functies op een lager niveau gehalveerd is van $16 \%$ in 2004 naar $8 \%$ in 2005. De horizontale doorstroom naar niet technische functies op eenzelfde functieniveau is daarentegen flink toegenomen. In 2005 gaf meer dan $80 \%$ van de bedrijven waarin technisch personeel doorstroomde naar niet-technische functies aan dat het ging om mobiliteit naar functies op hetzelfde niveau. In 2004 was dat nog slechts bij $40 \%$ van de bedrijven het geval. 


\section{Figuur 5.15}

Horizontale en verticale doorstroom naar niet-technische functies, 2004-2005 (\% van de bedrijven met doorstroom)

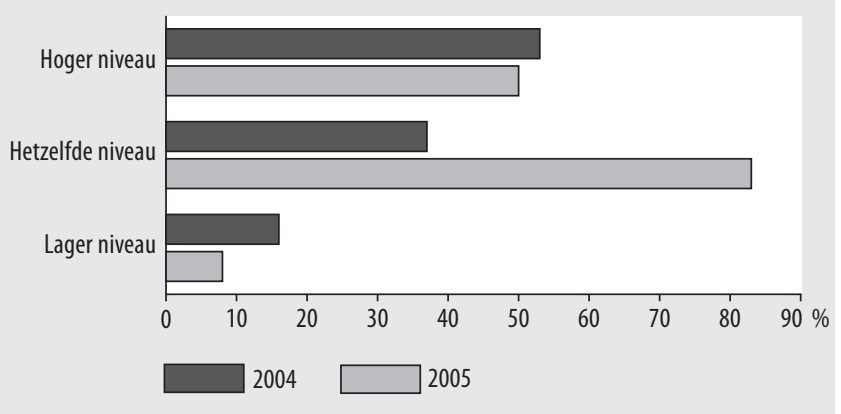

Bron: ROA/Werkgeverspanel Metalektro 2004-2005

De opwaartse mobiliteit van technisch personeel naar niet-technische functies is daarentegen niet sterk veranderd. In 2005 stroomde er in de helft van de metalektrobedrijven technisch personeel door naar niet technische functies op een hoger niveau. Het gaat hier waarschijnlijk voor een groot deel om uitvoerende en leidinggevende technici die doorstromen naar een managementfunctie.

Doorstroom van personeel is voor heel wat bedrijven erg belangrijk. Uit gesprekken met personeelsmanagers bleek dat bepaalde bedrijven het zich niet kunnen veroorloven om het personeel niet regelmatig van baan te laten veranderen. De ontwikkelingen waarmee bedrijven te maken krijgen en de innovaties die ze doorvoeren versterken dat alleen maar. Een personeelsfunctionaris: "Dat we veel geld uitgeven aan scholing is niet voldoende; het is minstens zo belangrijk om goede doorgroeiperspectieven te bieden". Het is dan ook niet verwonderlijk dat, zoals figuur 5.16 laat zien, het actief stimuleren van de mobiliteit in belang toeneemt. In 2004 gaf $58 \%$ van de metalektrobedrijven aan de doorstroom van het technisch personeel te stimuleren. In 2005 was dat al bij $65 \%$ van de bedrijven het geval.

Figuur 5.16

Stimuleren van de doorstroom van technisch personeel, 2004-2005 (\% bedrijven)

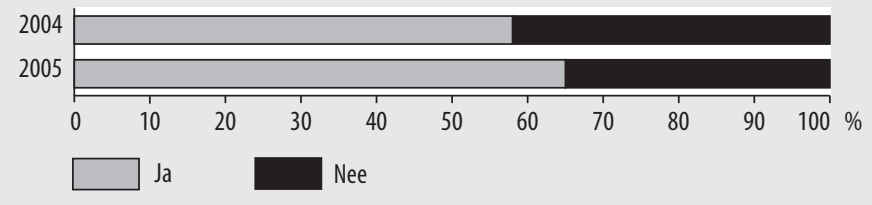

Bron: ROA/Werkgeverspanel Metalektro 2004-2005 


\section{HRM-beleid in de Metalektro}

"Dat functieroulatie de laatste belangrijker wordt, dat verbaast me niet. Het maakt het werk voor het personeel aantrekkelijker, zorgt voor meer flexibiliteit voor de bedrijven en draagt bij aan de employability van het personeel."

"Dat employability het personeel ook meer kansen biedt op de externe arbeidsmarkt, dat vinden we geen probleem. Als ze ontvreden zijn over de mogelijkheden die ze krijgen dan vertrekken ze namelijk ook."

"We gaan steeds meer over tot opleidingsafspraken met individuele werknemers, omdat afspraken op het niveau van het bedrijf vaak niet nageleefd worden."

"Ons HRM-beleid wordt steeds meer gericht op het uitvoeren van allerlei administratieve verplichtingen die erg veel tijd kosten."

"We besteden in ons HRM-beleid specifiek aandacht aan high potentials en aan vrouwen, maar bij die laatste groep hebben we nog niet echt bereikt wat we willen: meer vrouwen in managementfuncties."

"We kijken de laatste tijd ook veel meer naar de positie van leidinggevend personeel. Dat is van groot belang omdat die mensen nu en vooral in de toekomst echt goed om moeten kunnen gaan met mensen."

"Ons opleidingsbeleid verandert niet wezenlijk, maar we hebben wel steeds meer aandacht voor het oudere personeel."

"We kijken vooral naar hoe we het laaggeschoolde oudere personeel nog tot hun vroegpensioen nuttig en plezierig aan het werk kan blijven. Echt investeren in de kennis en vaardigheden van deze mensen is lastig, doordat ze vaak over onvoldoende leervermogen beschikken." 
HOOFDSTUK 6

De uitspraken van bedrijven maken duidelijk dat de metalektrosector steeds innovatiever te werk gaat bij het voeren van hun HRM-beleid. Om hier wat meer vat op te krijgen beginnen we dit hoofdstuk met een overzicht van de belangrijkste ontwikkelingen op $H R M$-gebied van de afgelopen jaren. Vervolgens kijken we naar de doelen die de bedrijven nastreven met hun HRM-beleid: Waarop is de inzet van verschillende HRM-instrumenten vooral gericht? We sluiten af met een overzicht van de doelgroepen waarvoor de bedrijven in hun HRM-beleid specifieke aandacht hebben. Daarbij komt onder meer aan de orde in hoeverre de metalektrobedrijven extra aandacht besteden aan de positie van ouder personeel, lager opgeleiden en mensen die al langer in dienst zijn. 


\subsection{Ontwikkelingen in de afgelopen jaren}

Bedrijven in de Metalektro zijn niet alleen op technologisch gebied innovatief. Ze gaan ook steeds innovatiever om met de mogelijkheden die het HRM-beleid biedt om een optimale ontwikkeling en inzet van het personeel te realiseren. Welke trends zijn er in het HRM-beleid van de metalektrobedrijven? Figuur 6.I geeft een overzicht van de ontwikkelingen van de laatste 4 jaar. Het gaat hier telkens om het percentage metalektrobedrijven dat een bepaald HRM-instrument inzet voor een meerderheid van het technisch personeel.

\section{Figuur 6.1}

Gebruikte HRM-instrumenten voor het technisch personeel, 2002-2005 (\% bedrijven)

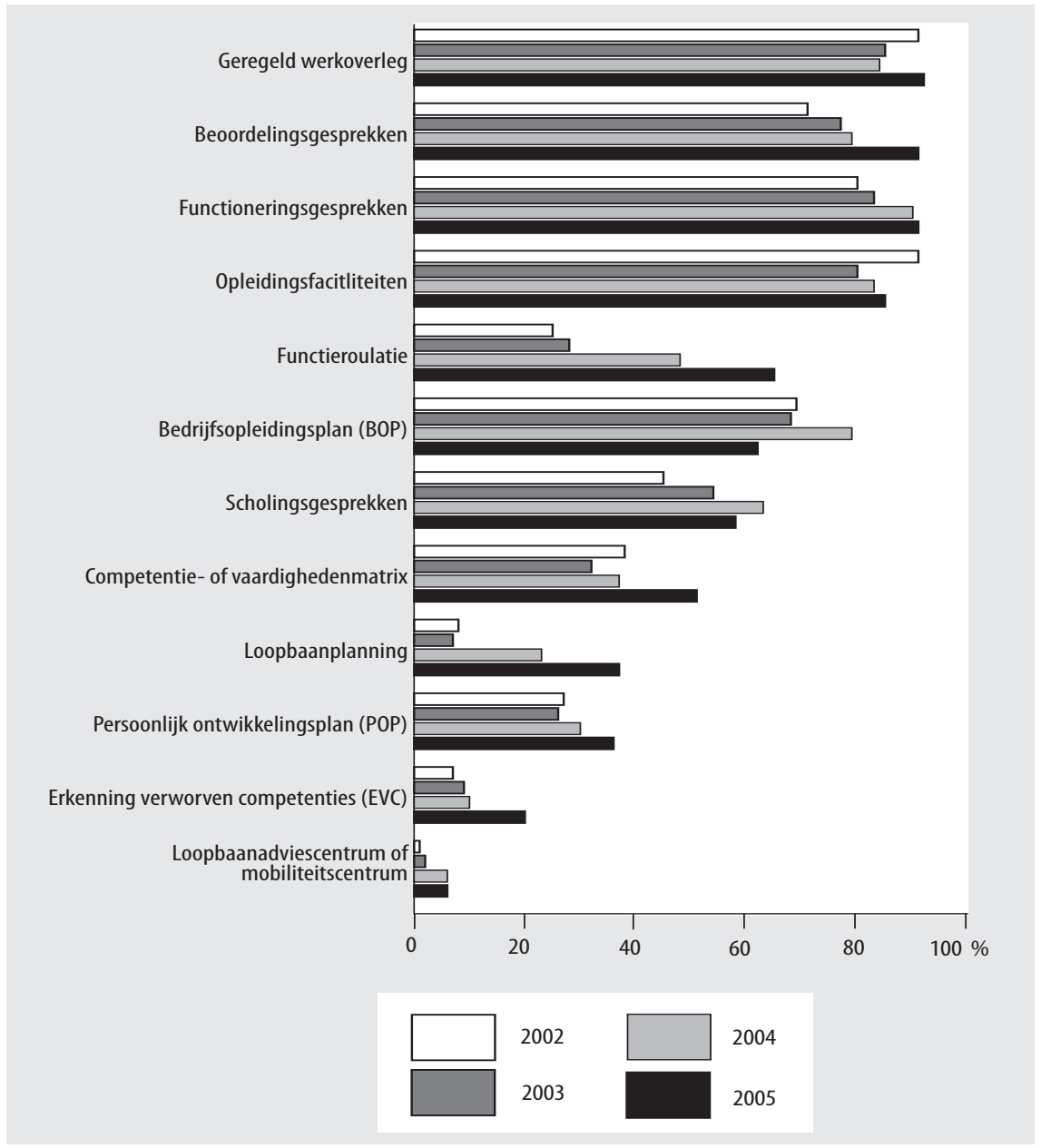

Bron: ROA/Werkgeverspanel Metalektro 2002-2005 
De figuur laat zien dat bijna alle bedrijven in de Metalektro geregeld werkoverleg met hun personeel voeren, beoordelings- of functioneringsgesprekken houden en het personeel opleidingsfaciliteiten aanbieden. Het houden van beoordelings- en functioneringsgesprekken is de laatste paar jaar steeds belangrijker geworden. Zo hield in 2002 nog maar $71 \%$ van de bedrijven beoordelingsgesprekken. In 2005 was dat gestegen tot $91 \%$. De toename in het belang van functioneringsgesprekken is ook substantieel: van $80 \%$ in 2002 tot $91 \%$ in 2005 . Geregeld werkoverleg, het meest toegepaste HRM-instrument, is in vergelijking met de jaren 2003 en 2004 ook iets in belang toegenomen. In 2005 werd er in maar liefst $92 \%$ van de bedrijven regelmatig werkoverleg gevoerd. Het aantal bedrijven met opleidingsfaciliteiten is de laatste twee jaar ook weer wat gestegen tot $85 \%$ van de bedrijven in 2005 , maar het is nog niet zo groot als in 2002, toen nog ruim $90 \%$ van de bedrijven hun technisch personeel opleidingsfaciliteiten aanbood.

Het is opvallend dat van de overige acht HRM-instrumenten er maar liefst vijf in belang toenemen. De stijging van het aantal bedrijven dat hun technisch personeel regelmatig rouleert (functieroulatie) is het spectaculairst: van $25 \%$ in 2002 tot $65 \%$ in 2005 . Dit betekent dat steeds meer bedrijven inzien dat functieroulatie bijdraagt aan het prestaties van het bedrijf. Een personeelsfunctionaris denkt dat daar verschillende redenen voor zijn: "Het maakt het werk voor het personeel veel aantrekkelijker en biedt nieuwe uitdagingen. Maar ook voor bedrijven is functieroulatie echt nodig om de benodigde flexibiliteit te realiseren. Wat ook meespeelt is dat functieroulatie bijdraagt aan de employability van het personeel". Dat mensen die geregeld van functie wisselen employable zijn en misschien elders aan de slag gaan, vindt hij geen groot probleem: "Als het personeel ontevreden is over de mogelijkheden die ze krijgen dan vertrekken ze namelijk ook".

Ook het aantal bedrijven dat actief bezig is met de loopbaanplanning van hun technisch personeel neemt de laatste jaren behoorlijk toe. In 2002 gaf nog slechts $8 \%$ van de bedrijven aan dat ze aandacht hadden voor de loopbaanplanning van hun technisch personeel. Vier jaar later zegt maar liefst $37 \%$ van de bedrijven dat ze actief met loopbaanplanning bezig zijn.

Een andere belangrijke ontwikkeling van de afgelopen jaren is dat het aantal bedrijven dat Erkenning van Verworven Competenties (EVC) - trajecten heeft ingevoerd is gestegen. Hoewel het totale aantal bedrijven dat EVC gebruikt nog beperkt is ( $20 \%$ in 2005), laten de ontwikkelingen van de laatste paar jaar wel zien dat EVC in steeds meer bedrijven een belangrijke rol gaat spelen. De verdubbeling van het aantal bedrijven dat met EVC werkt in 2005 bevestigt ook de in de Arbeidsmarktmonitor Metalektro 2004 uitgesproken verwachting dat er de komende jaren sprake zal zijn van een "takeoff" van het EVC-beleid in de Metalektro.

Er zijn ook steeds meer bedrijven die ertoe overgaan om meer in het algemeen de kennis en kunde van het technisch personeel in kaart te brengen door middel van 
een competentie- of vaardighedenmatrix. In 2002 ging het nog om minder dan $40 \%$ van de bedrijven; in 2005 gebruikte al meer dan de helft van de bedrijven een competentie- of vaardighedenmatrix. Dat zowel EVC als het gebruik van een competentie- of vaardighedenmatrix in belang toenemen is op zich niet verwonderlijk. In de dynamische productieomgeving van de metalektrobedrijven kan het goed in kaart brengen van de competenties van het technisch personeel immers de effectiviteit van het productieproces ten goede komen.

Steeds meer bedrijven gaan ertoe over om persoonlijke ontwikkelingsplannen (POP's) voor hun personeel op te stellen. In 2002 was er nog slechts in $27 \%$ van de bedrijven sprake van POP's. In 2005 stelde al $36 \%$ van de bedrijven persoonlijke ontwikkelingsplannen voor het technisch personeel op. De toegenomen aandacht voor POP's gaat gepaard met een daling van het aantal bedrijven met een bedrijfsopleidingsplan (BOP). Dit terwijl zowel de subsidies voor POP's als BOP's grotendeels zijn afgeschaft. De toenemende aandacht voor POP's onderstreept de individualisering van de opleidingsinspanningen. Bedrijven vinden het blijkbaar steeds belangrijker dat de opleidingsambities betrekking hebben op de individuele werknemers. Volgens een bedrijf uit de elektrotechniek heeft dat ook in de praktijk grote voordelen: "Je kunt op het niveau van het bedrijf wel afspraken maken, maar die worden vaak niet nageleefd omdat de leiding er niet altijd het nut van inziet. Daarom maken we voor iedereen afzonderlijk een opleidingsplan”.

$58 \%$ van de metalektrobedrijven hield in 2005 scholingsgesprekken met het technisch personeel. In vergelijking met het 2004 is het belang van scholingsgesprekken wat afgenomen. Waarschijnlijk is deze daling het gevolg van het feit dat in een aantal bedrijven de scholingsgesprekken zijn geëvalueerd tot POP's. Daarentegen hebben nog steeds erg weinig bedrijven de beschikking over een loopbaanadvies- of mobiliteitscentrum. Het aantal bedrijven dat over een dergelijk centrum beschikt is tussen 2002 en 2004 weliswaar gestegen, maar die groei heeft zich in 2005 niet doorgezet. Dergelijke centra zijn natuurlijk ook lang niet voor alle bedrijven weggelegd. In de praktijk zullen alleen de grootste bedrijven in de Metalektro de kosten van een loopbaanadviescentrum of mobiliteitscentrum kunnen dragen.

Een opvallende constatering is dat meerdere bedrijven tijdens de interviews aangaven dat de administratieve verplichtingen die de HRM-afdelingen de laatste jaren moeten vervullen de afgelopen jaren steeds meer tijd zijn gaan kosten. Een personeelsfunctionaris: "De administratieve verplichtingen zijn groter geworden, doordat er op allerlei terreinen veel verandert. Het gaat dan bijvoorbeeld om de WIA en de nieuwe ziektekostenverzekering". Een ander bedrijf is het daarmee eens: "Ons HRM-beleid wordt steeds meer gericht op het uitvoeren van verplichte zaken. Je wordt automatisch die kant opgeduwd doordat er zoveel wetten en regelingen zijn waarmee je rekening moet houden: de wet arbeid en zorg, de levensloopregeling, ouderschapsverlof, de wet poortwachter. Het kost allemaal erg veel tijd". 


\subsection{Waarop is het HRM gericht?}

Bedrijven kunnen met de inzet van bepaalde HRM-instrumenten verschillende doelen nastreven. Figuur 6.2 geeft een overzicht van de mate waarin verschillende HRM-instrumenten gericht zijn op vier doelen:

- het beperken van het personeelsverloop

- het beleid van oudere werknemers $\left(45^{+}\right)$ondersteunen

- het bevorderen van de doorstroom

- het stimuleren van de inzetbaarheid van het personeel.

\section{Figuur 6.2}

Doelen waarop HRM-instrumenten zijn gericht, 2005 (in \% van de bedrijven die het HRM-instrument gebruiken)

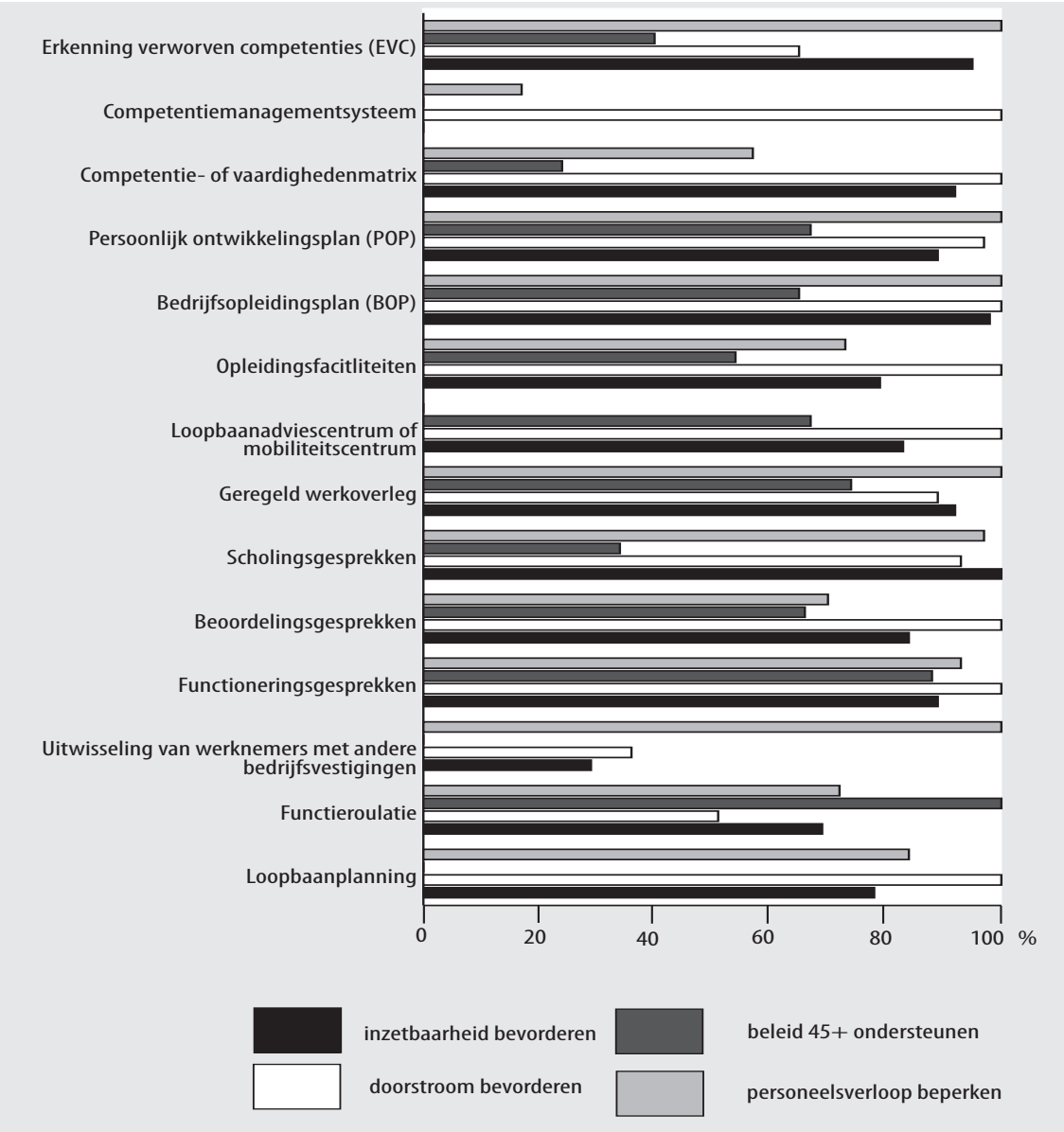

Bron: ROA/Werkgeverspanel Metalektro 2005 
De figuur laat zien dat het erkennen van verworven competenties (EVC) vooral als doel heeft het personeelsverloop te verminderen en de inzetbaarheid van medewerkers te vergroten. Maar ook ruim 60\% van de bedrijven probeert door middel van EVC de doorstroom te bevorderen. Een competentiemanagementsysteem blijkt daarentegen vooral gericht te zijn op het bevorderen van de doorstroom. Een competentie- of vaardighedenmatrix wordt eveneens vooral ingezet om de doorstroom van het technisch personeel te bevorderen maar beoogt daarnaast ook de inzetbaarheid te stimuleren. De helft van de bedrijven probeert door het gebruik van een competentie- of vaardighedenmatrix ook het personeelsverloop te beperken. Met persoonlijke opleidingsplannen, bedrijfsopleidingsplannen en opleidingsfaciliteiten streven bedrijven verschillende doelen tegelijk na: Het verminderen van het personeelsverloop, het bevorderen van de doorstroom van personeel, het bevorderen van de inzetbaarheid en in iets mindere mate het ondersteunen van het beleid voor oudere $\left(45^{+}\right)$werknemers.

De bedrijven die een loopbaanadvies- of mobiliteitscentrum hebben proberen hiermee vooral de doorstroom van personeel te bevorderen. Maar een meerderheid van de bedrijven met deze centra geeft ook aan dat ze hiermee het beleid voor oudere werknemers kunnen ondersteunen en de inzetbaarheid van het technisch personeel willen bevorderen.

Een viertal HRM-instrumenten heeft betrekking op de communicatie met het technisch personeel: het hebben van geregeld werkoverleg en scholings-, beoordelings- en functioneringsgesprekken. Met deze HRM-instrumenten proberen bedrijven bijna alle vier genoemde HRM-doelen na te streven. Alleen scholingsgesprekken worden slechts in een derde van de bedrijven ingezet om het beleid voor $45+$ 'ers te ondersteunen.

Met het uitwisselen van werknemers met andere bedrijfsvestigingen streven de meeste bedrijven daarentegen slechts één doel na: het beperken van het personeelsverloop. Bedrijven beseffen dus dat de personeelsuitwisseling het werk van het technisch personeel afwisselender maakt, waardoor goede medewerkers minder behoefte hebben naar een ander bedrijf te vertrekken.

Functieroulatie wordt vooral ingezet om het beleid voor oudere werknemers te ondersteunen. Het gaat dan meestal om het aanpassen van functies van oudere werknemers met als doel de werkbelasting te verminderen. Functieroulatie is echter ook in veel bedrijven een middel om het personeelsverloop te beperken en de inzetbaarheid van het personeel te vergroten. Het verloop kan beperkt worden doordat functieroulatie er toe kan bijdragen dat het werk afwisselender wordt. Functieroulatie vergroot de inzetbaarheid van het personeel omdat werknemers zich hierdoor breed ontwikkelen en daardoor voor meerdere functies kunnen worden ingezet. 
Het is opmerkelijk dat loopbaanplanning in de metalektrobedrijven helemaal niet wordt ingezet om het beleid gericht op oudere werknemers te ondersteunen. Dit betekent dat loopbaanplanning in het algemeen meer gericht is op het jongere personeel. De bedrijven zetten loopbaanplanning wel in om het personeelsverloop te beperken, de inzetbaarheid te vergroten en de doorstroom te bevorderen.

\subsection{Doelgroepen in het HRM-beleid}

In hoeverre houden bedrijven in hun HRM-beleid rekening met specifieke groepen werknemers? Figuur 6.3 laat zien dat dit in de metalektrobedrijven nog nauwelijks het geval is. Ongeveer een derde van de bedrijven geeft aan speciale aandacht te besteden aan jongeren en leidinggevenden. Daarentegen besteedt slechts $20 \%$ van de bedrijven expliciet aandacht aan de positie van oudere werknemers $(45+)$ of lager opgeleiden. Het feit dat veel bedrijven nog niet duidelijk aandacht besteden aan hun oudere personeel staat in schil contrast met de aanzienlijke vergrijzing van hun personeelsbestand en de mogelijke problemen die ze zullen krijgen wanneer het oudere personeel in de toekomst vervangen moet worden (zie ook hoofdstuk 7).

\section{Figuur 6.3}

Aandacht voor specifieke groepen personeel, 2005 (\% bedrijven)

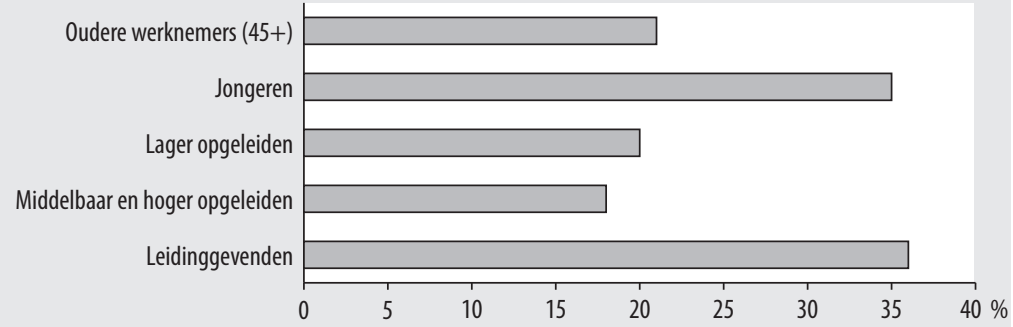

Bron: ROA/Werkgeverspanel Metalektro 2005

Uit interviews met een aantal bedrijven die aan het werkgeverspanel deelnemen blijkt echter wel dat de aandacht voor het oudere personeel langzaam toeneemt. Een personeelsmanager: "Ons opleidingsbeleid op zich, dat verandert niet zoveel, maar we hebben wel steeds meer aandacht voor het oudere personeel". Ook de aandacht voor de positie van leidinggevend personeel groeit: "Vroeger was dat niet echt nodig, maar leidinggevenden moeten nu en vooral in de toekomst echt goed om kunnen gaan met mensen."

Bepaalde bedrijven besteden in hun HRM-beleid specifiek aandacht aan groepen personeel die niet in figuur 6.3 genoemd worden, zo bleek uit gesprekken. In verschillende bedrijven richt het HRM-beleid zich specifiek op de ontwikkeling van 'high potentials'. Een enkel bedrijf besteedt extra aandacht aan de positie van vrouwelijke werknemers: "We proberen meer vrouwen in managementfuncties te krijgen door ze 
extra kansen te bieden. Dat lukt tot op heden nog niet echt goed. Dat we nog niet zoveel succes hebben komt doordat het aantal potentieel geschikte vrouwelijke kandidaten nog te klein is. Verder speelt vaak mee dat vrouwen hun loopbaan onderbreken en daarna part-time terugkomen. Dat maakt goed functioneren in managementfuncties vaak lastig".

\section{Aandacht voor ouder personeel}

Op welke wijze besteden bedrijven aandacht aan hun oudere personeel? Figuur 6.4 laat zien dat in meer dan 70\% van de kleine groep bedrijven met HRM-beleid gericht op oudere werknemers (20\% van alle bedrijven) de overdracht van kennis centraal staat. $58 \%$ van de bedrijven met beleid gericht op oudere werknemers richt zich op mogelijkheden om voor oudere werknemers ander werk te zoeken. Bijna de helft van de bedrijven met expliciete aandacht voor oudere werknemers houdt loopbaangesprekken. Een aantal bedrijven zoekt naar mogelijkheden om het werk voor oudere werknemers anders te organiseren ( $13 \%)$, of probeert ploegendiensten anders in te plannen (I2\%). Ten slotte organiseert $8 \%$ van de bedrijven in het kader van hun beleid voor oudere werknemers speciale workshops.

\section{Figuur 6.4}

Manieren waarop aan 45+'ers aandacht wordt besteed, 2005 (\% bedrijven)

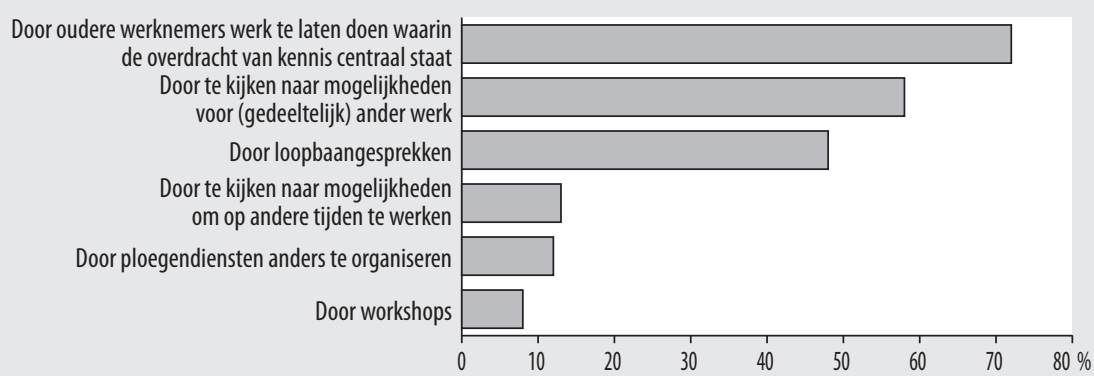

Bron: ROA/Werkgeverspanel Metalektro 2005

Uit de gehouden interviews kwam naar voren dat er bij de bedrijven die specifiek aandacht aan hun oudere personeel besteden vaak geen sprake is van een investeringsstrategie, waarbij de nadruk ligt op het verbeteren van de kennis en vaardigheden van het personeel. Bedrijven richten zich veel meer op een soort behoudsstrategie. Een personeelsfunctionaris legt dat uit: "Onze aandacht voor oudere werknemers is vooral gericht op het bepalen van welke groepen werknemers nog mee kunnen met de veranderingen. Echt investeren in de kennis en vaardigheden van het oudere personeel is lastig, doordat hun leervermogen vaak tekortschiet, maar we zijn niet van plan die mensen buiten te zetten. Daarom is de uitdaging om ervoor te zorgen dat deze werknemers nog tot hun vroegpensioen nuttig en plezierig aan de slag blijven”. 


\section{Aandacht voor personeel dat al langer in dienst is}

Bedrijven kunnen in hun personeelsbeleid ook expliciet aandacht besteden aan de loopbaanmogelijkheden van het personeel met een lange loopbaan in het bedrijf. Figuur 6.5 geeft een overzicht van de mate waarin bedrijven hieraan aandacht besteden. Een derde van de bedrijven heeft geen aparte aandacht voor de loopbaanmogelijkheden van technisch personeel met veel jaren diensttijd; $42 \%$ van de bedrijven heeft slechts beperkte aandacht voor personeel dat al langer in dienst is. Het resterende kwart van de metalektrobedrijven besteedt daarentegen in hun personeelsbeleid veel aandacht aan technisch personeel met veel dienstjaren.

\section{Figuur 6.5}

Speciale aandacht voor de loopbaanmogelijkheden van technisch personeel dat al langer in dienst is, 2005 (\% bedrijven)

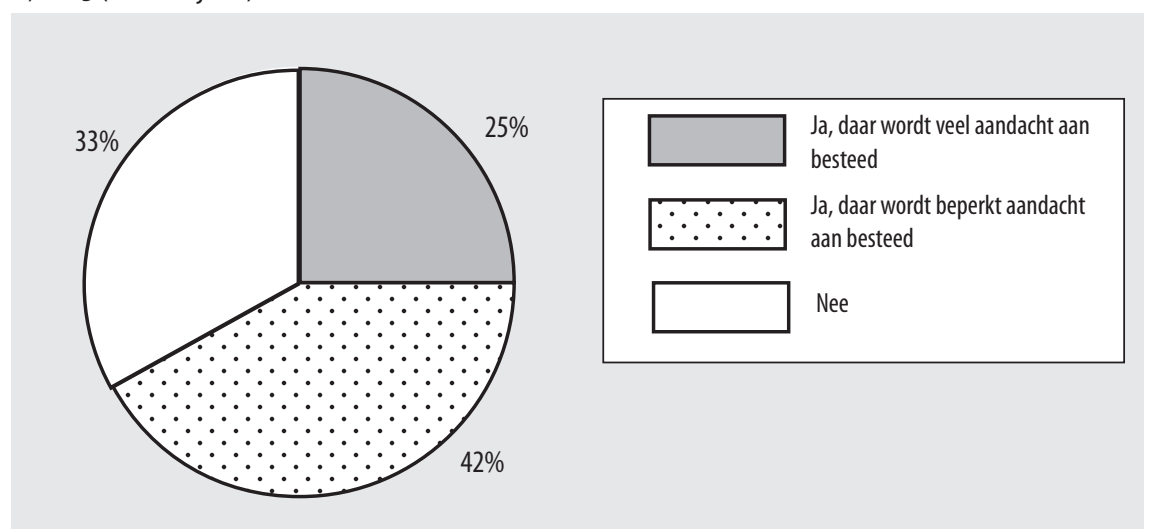

Bron: ROA/Werkgeverspanel Metalektro 2005

Op welke manieren hebben metalektrobedrijven aandacht voor de loopbaanmogelijkheden van het technisch personeel dat al langer in dienst is? Figuur 6.6 laat zien dat $90 \%$ van de bedrijven die op dit punt beleid voeren tijdens gesprekken (functioneringsgesprekken, e.d.) expliciet ingaan op de loopbaanmogelijkheden van het personeel met veel dienstjaren. Bijna 60\% van de bedrijven vergroot de loopbaanmogelijkheden van het personeel dat al langer in dienst is door interne vacatures aan iedereen bekend te maken. 44\% van de bedrijven met een HRM-beleid dat zich richt op personeel met een lange diensttijd stimuleert de loopbaanmogelijkheden voor het technisch personeel door hen een bepaald doorgroeiperspectief te bieden. Daarentegen probeert slechts $15 \%$ van de bedrijven de loopbaanmogelijkheden van het personeel met een lange loopbaan in het bedrijf te bevorderen door de deelname aan cursussen of trainingen te belonen met promoties. Uit interviews met bedrijven kwam naar voren dat bedrijven het leidinggevend personeel dat al langer in dienst is soms ook ontwikkelen door speciale opleidingstrajecten: "we zoeken aansluiting met een opleidingsinstituut en we werken daarmee samen om ervoor te zorgen dat onze 
leidinggevenden de juiste dingen leren. We vinden het belangrijk om erg betrokken te zijn bij de inhoud van die trajecten".

\section{Figuur 6.6}

Wijze waarop aan loopbaanmogelijkheden van personeel dat al langer in dienst is aandacht wordt besteed, 2005 (\% bedrijven)

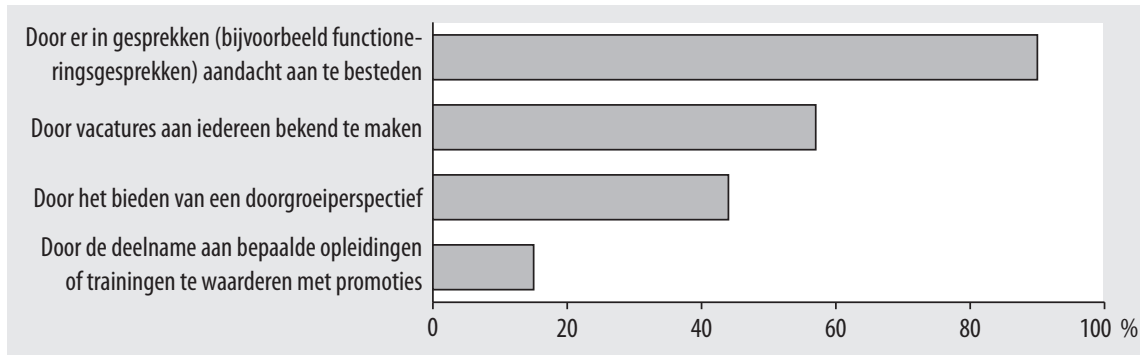

Bron: ROA/Werkgeverspanel Metalektro 2005 



\section{De Metalektro in de toekomst}

"Inzetbaarheid, daar kunnen we nooit genoeg van hebben."

"We sturen de komende jaren steeds meer aan op een maximalisering van de flexibele inzetbaarheid door mensen ook daadwerkelijk flexibel in te zetten."

"We hebben nu wel contacten op bestuursniveau maar nog veel te weinig met de opleidingen zelf."

"Ons HRM-beleid zal de komende jaren ingrijpend veranderen doordat we ons veel meer op de menselijke kant gaan richten."

"Een stuk inzetbaarheid moet wel vanuit de mensen zelf komen."

"Het is een soort ruilrelatie. Wij bieden de mensen mogelijkheden wanneer ze zich flexibel op stellen en prestatiegericht zijn."

"We gaan in ons toekomstig opleidingsbeleid veel meer de nadruk leggen op soft skills zoals teamwork, het kunnen aansturen van mensen en communicatieve vaardigheden."

"Goed kunnen communiceren wordt in de komende jaren echt een sleutelvaardigheid."

De citaten maken direct duidelijk dat de metalektrobedrijven de komende jaren erg veel behoefte hebben aan een flexibel en breed inzetbaar personeelsbestand. In dit hoofdstuk kijken we naar hoe de bedrijven daar met hun toekomstige opleidings-en HRM-beleid op willen gaan inspelen: Wat gaan de bedrijven doen om met de ontwikkelingen waarmee ze geconfronteerd worden om te gaan en hoe stemmen ze hun HRM-beleid daar op af? Welke competenties worden in het toekomstig opleidingsbeleid belangrijker? Voordat we ingaan op het HRM-beleid dat bedrijven in de komende jaren verwachten te zullen voeren besteden we echter eerst aandacht aan twee andere belangrijke ontwikkelingen: de verwachte ontwikkelingen op de arbeidsmarkt en de rol die de vergrijzing van het personeelsbestand de komende jaren zal spelen. We besteden ook aandacht aan de manieren waarop de Metalektrobedrijven om zullen gaan met vervangingsproblemen die kunnen ontstaan wanneer veel oudere werknemers de metalektosector in de komende jaren verlaten. 


\subsection{Verwachte arbeidsmarktontwikkelingen}

Voor metalektrobedrijven is het van groot belang om goed inzicht te hebben in de wijze waarop de arbeidsmarkt zich in de komende jaren zal ontwikkelen. Deze ontwikkelingen bepalen immers de context waarbinnen bedrijven hun HRM-beleid zullen moeten voeren. Hoe zal de arbeidsmarktsituatie zich in de komende jaren ontwikkelen? We kijken eerst naar de arbeidsmarktprognoses voor beroepsgroepen die voor de metalektrobedrijven van belang zijn. Daarna gaan we in op de prognoses voor een aantal voor de sector belangrijke specifieke opleidingen. Als laatste bekijken we in hoeverre de verwachte arbeidsmarktontwikkelingen leiden tot knelpunten in de personeelsvoorziening.

\section{Arbeidsmarktprognoses voor specifieke functies}

Hoe zal zich de vraag naar personeel in de voor de Metalektro relevante functies zich de komende jaren ontwikkelen? Figuur 7.I laat zien dat de verwachte uitbreidingsvraag voor een aantal technische functies negatief is. Zo wordt er een krimpende werkgelegenheid verwacht voor metaalbewerkers, monteurs, bankwerkers en lassers, productiemedewerkers, elektromonteurs, werktuigbouwkundig ontwerpers en hoofden technische dienst en assembleurs. De verwachte krimp is het grootst voor productiemedewerkers $(-2,9 \%$ per jaar) en voor de beroepsgroep 'werktuigbouwkundig ontwerpers en hoofden technische dienst' ( $-4,7 \%$ per jaar). Er is echter ook een aantal technische functies waarvoor er naar verwachting sprake zal zijn van een groeiende werkgelegenheid. Voor zowel laders en lossers als systeemanalisten en installateurs zal de werkgelegenheid tot 2010 naar verwachting toenemen.

Het is opmerkelijk dat de uitbreidingsvraag voor drie van de vier administratieve functies die relevant zijn in de Metalektro positief is. Voor administratief personeel wordt de komende jaren een werkgelegenheidsgroei van I, $5 \%$ op jaarbasis verwacht. De groei is wat beperkter voor receptionisten en administratieve employés. De enige niet-technische functie waarvoor er sprake zal zijn van een krimpende werkgelegenheid betreft commercieel medewerkers op WO niveau.

Naast de vraag naar personeel als gevolg van werkgelegenheidsgroei is er ook sprake van een vervangingsbehoefte, die ontstaat doordat personeel vanwege pensioen of om andere redenen de arbeidsmarkt verlaat. Bij de meeste technische functies is er sprake van een forse vervangingsvraag, omdat veel vergrijsd technisch personeel de komende jaren de arbeidsmarkt zal verlaten. De top-3 wordt gevormd door assembleurs ( $4,9 \%$ per jaar), werktuigbouwkundig ontwerpers en hoofden technische dienst ( $4,7 \%$ op jaarbasis) en metaalbewerkers $(4,6 \%$ per jaar). Ook de vervangingsvraag voor monteurs, bankwerkers en lassers, productiemedewerkers en elektromonteurs zal de komende jaren aanzienlijk zijn. Circa $4 \%$ van de mensen die in deze functies werkzaam zijn zal tot 2010 jaarlijks vervangen moeten worden. De vervangingsbehoefte is wat kleiner voor laders en lossers $(3 \%)$, systeemanalisten $(\mathrm{I}, 2 \%)$ en installateurs $(3,2 \%)$. 
Het aantal oudere werknemers in deze functies is wat geringer, waardoor de vervangingsvraag als gevolg van de arbeidsmarktuitstroom beperkter is. Bij de niet-technische functies is de vervangingsbehoefte in het algemeen lager dan bij de technische beroepen. Alleen voor receptionisten en administratieve employés zal er de komende jaren naar verwachting sprake zijn van een vervangingsvraag van $3, \mathrm{I} \%$ op jaarbasis. Bij de overige drie niet-technische functies die relevant zijn voor de Metalektro bedraagt de verwachte vervangingsbehoefte jaarlijks circa $2 \%$.

\section{Figuur 7.1}

Uitbreidingsvraag, vervangingsvraag en totaal aantal baanopeningen per beroepsgroep, 2005-2010 (gemiddeld jaarlijks \% van de werkgelegenheid)

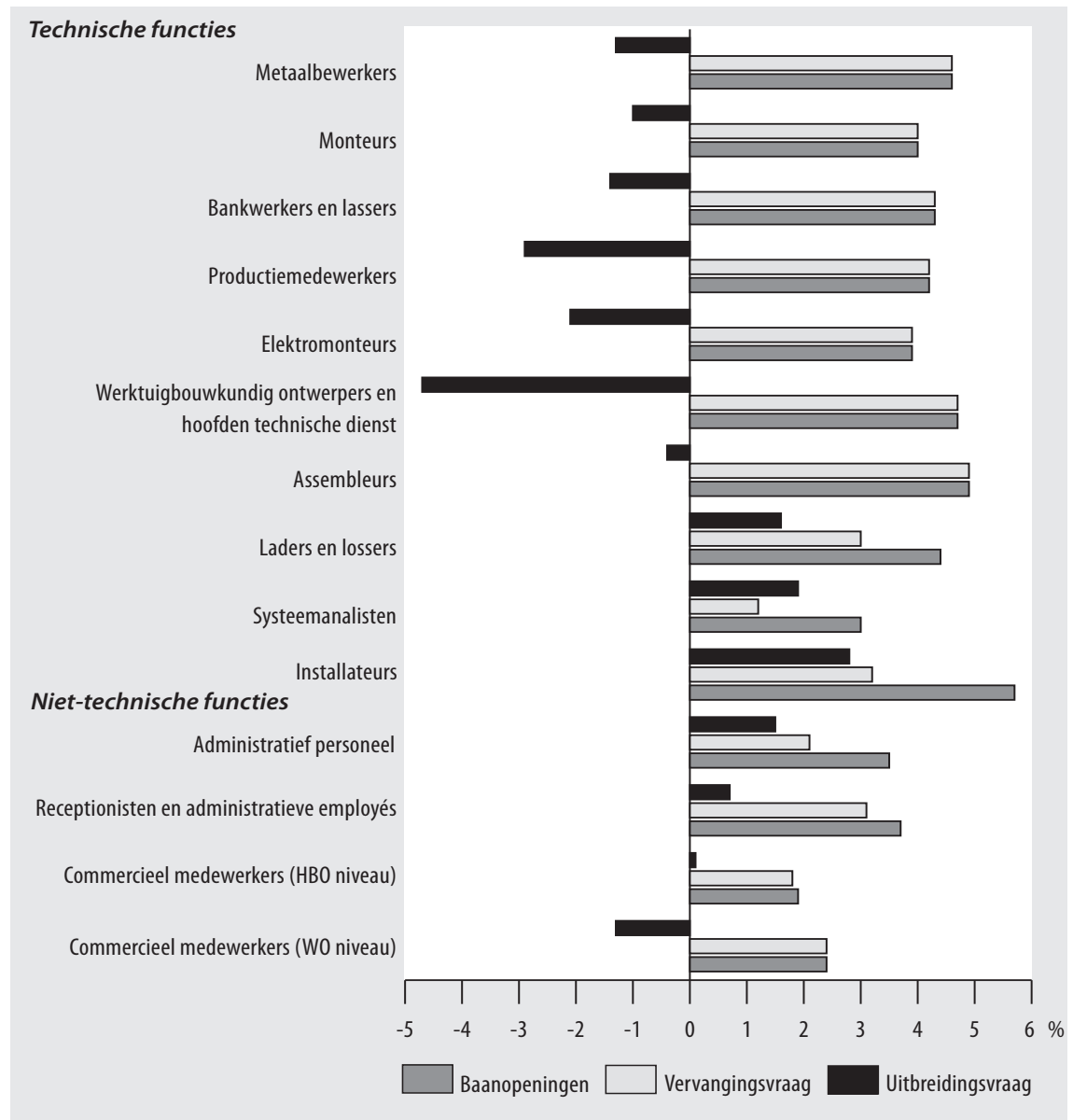

\section{Bron: ROA/CBS}

Figuur 7.I geeft ook informatie over het totaal aantal baanopeningen voor de technische en niet-technische functies. Bij een groeiende werkgelegenheid is het aantal baanopeningen gelijk aan de som van de uitbreidingsvraag en de vervangingsvraag. 
Bij krimp is het aantal baanopeningen daarentegen gelijk aan de vervangingsvraag. Dit is gebaseerd op het feit dat, op sectorniveau, de werkgelegenheidskrimp doorgaans geen negatief effect heeft op de behoefte aan nieuw personeel op grond van de vervangingsvraag.

Dit betekent dat er ondanks de krimpende werkgelegenheid in een aantal technische functies, in vrijwel alle functies sprake zal zijn van een behoorlijke vraag naar nieuwkomers. Voor de functies met een krimpende werkgelegenheid bedraagt het aantal baanopeningen jaarlijks circa $4-5 \%$ van de totale werkgelegenheid in deze functies. Voor de technische functies waarvoor de komende jaren een groeiende werkgelegenheid wordt verwacht, zal het aantal baanopeningen naar verwachting op hetzelfde niveau liggen. Alleen het aantal baanopeningen voor installateurs is opvallend hoog ( $5,7 \%$ op jaarbasis). Voor systeemanalisten zal het aantal baanopeningen met $3 \%$ per jaar daarentegen wat beperkter zijn. Dit is overigens ook de enige functie waarvoor de baanopeningen, vanwege het geringe aantal ouderen in deze functies, voor het grootste gedeelte het gevolg zijn van een groeiende werkgelegenheid.

Het aantal baanopeningen voor niet-technische functies zal in de komende jaren, mede door de kleinere vervangingsbehoefte, wat kleiner zijn dan het aantal baanopeningen in de technische functies. Voor de administratieve functies worden de meeste baanopeningen verwacht. Het aantal nieuwe banen voor commercieel medewerkers op $\mathrm{HBO}$ en WO niveau zal daarentegen de komende jaren op een lager niveau liggen.

\section{Arbeidsmarktprognoses voor specifieke opleidingen}

In de praktijk gaat het er vaak om om mensen met een bepaalde opleidingsachtergrond aan te trekken. Daarom is het erg belangrijk om inzicht te hebben in de verwachte vraag en aanbodontwikkelingen voor specifieke opleidingen, die voor de bedrijven in de Metalektro van belang zijn. Figuur 7.2 geeft een overzicht van de baanopeningen in de jaren 2005-20I0 voor een aantal opleidingen die relevant zijn in de Metalektro. Daarbij wordt de vraag ook verbijzonderd naar de uitbreidingsvraag en de vervangingsbehoefte. Het gaat hier overigens niet alleen om de vraag naar nieuwe mensen in de Metalektro, maar om de totale vraag naar mensen met een bepaalde opleidingsachtergrond. Uit de figuur blijkt dat de verwachte uitbreidingvraag slechts voor vier opleidingen negatief is: VMBO metaal (jaarlijks -0,I\%), MBO elektrotechniek (-o,4\% per jaar), MBO werktuigbouw en mechanische techniek (-0,4\% op jaarbasis) en $\mathrm{HBO}$ werktuigbouwkunde (-0,7\% per jaar). Voor alle overige opleidingen is de totale werkgelegenheid stabiel of is er sprake van een groeiende werkgelegenheid. Het is opvallend dat de verwachte groei geconcentreerd is in de niet-technische opleidingen. Voor werknemers met alleen basisonderwijs wordt een bescheiden groei van $0,6 \%$ per jaar verwacht. Voor mensen met een opleiding HBO bedrijfskunde is de verwachte groei het grootst: $2,3 \%$ op jaarbasis. De verwachte groei voor de overige niet-technische opleidingen bedraagt circa I\% per jaar. 


\section{Figuur 7.2}

Uitbreidingsvraag, vervangingsvraag en totaal aantal baanopeningen per opleidingstype, 20052010 (gemiddeld jaarlijks \% van de werkgelegenheid)



Bron: ROA/CBS

De vervangingsvraag naar personeel met een technische opleiding op VMBO of $\mathrm{MBO}$ niveau zal de komende jaren behoorlijk groot zijn. Voor de opleidingen VMBO metaal, VMBO bouw, $\mathrm{MBO}$ elektrotechniek en $\mathrm{MBO}$ werktuigbouwkunde en mechanische techniek wordt een vervangingsvraag van $4-5 \%$ per jaar verwacht. De vervangingsvraag naar mensen met een technische $\mathrm{HBO}$ opleiding is wat lager: 2,5\% per jaar voor mensen met een opleiding $\mathrm{HBO}$ werktuigbouwkunde en $2,8 \%$ voor personeel met een HBO-opleiding bedrijfskunde. Deze lagere vervangingsvraag is het gevolg van het feit dat het huidige personeel met deze kwalificaties wat minder oud is dan het personeel dat een technische functie op lager of middelbaar niveau gevolgd heeft, 
waardoor de uitstroom vanwege (pré-)pensionering beperkter is. De vervangingsvraag naar personeel met een niet-technische opleiding is met respectievelijk 4,9\% en 3,5\% per jaar het hoogst voor mensen met alleen basisonderwijs of VMBO theoretische leerweg. Het is echter onzeker of al deze mensen ook daadwerkelijk zullen worden vervangen. Door de upgrading van de functie-eisen kiezen bedrijven namelijk steeds vaker voor personeel dat tenminste een middelbare beroepsopleiding heeft afgerond.

Aangezien de werkgelegenheid voor de meeste technische opleidingen niet toeneemt, is het totaal aantal baanopeningen voor deze opleidingen vrijwel gelijk aan de vervangingsvraag. Voor de opleidingen VMBO metaal, VMBO bouw, MBO elektrotechniek en $\mathrm{MBO}$ werktuigbouwkunde en mechanische techniek is het totaal aantal baanopeningen daarom circa $4-5 \%$ per jaar. Voor de twee technische opleidingen op HBO niveau is het aantal baanopeningen wat kleiner.

Door de relatief grote vervangingsbehoefte is het aantal baanopeningen bij de niettechnische opleidingen het grootst voor mensen met alleen basisonderwijs of mensen die de theoretische leerweg in het VMBO hebben afgerond. Het is echter de vraag of deze baanopeningen zich de komende jaren ook daadwerkelijk zullen manifesteren, aangezien veel bedrijven hun lager opgeleid personeel vervangen door middelbaar of hoger opgeleide mensen. Aan de andere kant mag verwacht worden dat wanneer het voor bedrijven moeilijker wordt om MBO'ers te werven, een aantal bedrijven er toe zal overgaan om schoolverlaters zonder een dergelijke 'startkwalificatie' zelf verder te gaan opleiden. Voor MBO'ers met een opleiding administratie en logistiek zal het aantal nieuwe banen de komende jaren $4 \%$ van het huidige aantal werkenden met deze opleidingsachtergrond bedragen. Het aantal baanopeningen voor de overige niettechnische opleidingen zal naar verwachting wat beperkter zijn. Het aantal nieuwe banen voor mensen met een opleiding HAVO/VWO zal het kleinst zijn (2,6\% per jaar).

\section{Knelpunten in de personeelsvoorziening}

In hoeverre leiden de verwachte uitbreidings- en vervangingsvraag tot knelpunten in de personeelsvoorziening? Door de verwachte vraag naar personeel met een bepaalde opleidingsachtergrond te confronteren met het verwachte arbeidsmarktaanbod van deze mensen krijgen we een indicatie van de verwachte knelpunten in de personeelsvoorziening. Figuur 7.3 geeft een overzicht van de verwachte knelpunten in de personeelsvoorziening voor de opleidingen die relevant zijn in de metalektrosector. Voor deze figuur geldt: hoe korter de staaf, des te groter de verwachte knelpunten in de personeelsvoorziening.

De figuur laat zien dat de knelpunten in de personeelsvoorziening voor werknemers met een opleiding $\mathrm{VMBO}$ metaal of $\mathrm{MBO}$ werktuigbouw en mechanische techniek naar verwachting het grootst zullen zijn. Daarnaast zullen bedrijven in de Metalektro de komende jaren te maken krijgen met grote knelpunten voor personeel met een 
opleiding VMBO theoretische leerweg, MBO elektrotechniek en $\mathrm{MBO}$ administratie en logistiek. Deze knelpunten worden vooral veroorzaakt door het feit dat het huidige lager en middelbaar opgeleid personeel in de metalektrobedrijven relatief oud is, wat leidt tot een grote vervangingsbehoefte. Het valt overigens nog te bezien in hoeverre de verwachte knelpunten op VMBO-niveau echt ernstig zullen zijn, omdat de upgrading van de functie-eisen er toe leidt dat veel bedrijven hun lager opgeleid personeel dat met pensioen gaat, vervangen door middelbaar of hoger opgeleiden. Voor personeel met een opleiding VMBO bouw, $\mathrm{HBO}$ elektrotechniek, HAVO/VWO en basisonderwijs zal er de komende jaren sprake zijn van enige knelpunten.

\section{Figuur 7.3}

Indicator Toekomstige Knelpunten in de Personeelsvoorziening (ITKP) voor de belangrijkste opleidingstypen binnen de metaal en elektrotechnische sector, 2005-2010




$\mathrm{Bij}$ het aantrekken van personeel met een opleiding $\mathrm{HBO}$ bedrijfskunde, $\mathrm{MBO}$ handel of $\mathrm{HBO}$ werktuigbouwkunde zullen er de komende jaren vrijwel geen knelpunten optreden. Dat er weinig of geen knelpunten zullen optreden bij het aantrekken van personeel met deze opleidingen, terwijl er wel sprake zal zijn van een redelijke vraag (zie figuur 7.2), betekent dat er de komende tijd voldoende personeel met deze kwalificaties beschikbaar zal zijn.

\subsection{Vergrijzing}

Veel metalektrobedrijven hebben te maken met een nogal vergrijsd personeelsbestand. Hierdoor zal er de komende jaren sprake zijn van een grote uitstroom van personeel dat met pensioen gaat. Figuur 7.4 geeft, per functiecategorie een overzicht van het percentage werknemers dat de komende 5 jaar met pensioen zal gaan.

\section{Figuur 7.4}

Gemiddeld percentage werknemers dat binnen 5 jaar met pensioen gaat, naar functiecategorie, 2005



Bron: ROA/Werkgeverspanel Metalektro 2005

Het is duidelijk dat de vergrijzing bij het uitvoerend technisch personeel en het leidinggevend personeel het verst is voortgeschreden. Bijna $7 \%$ van de uitvoerende technici en circa $6 \%$ van de leidinggevende technici zal naar verwachting de komende 5 jaar met pensioen gaan. Bij de overige functiecategorieën is de verwachte uitstroom kleiner. Voor het ondersteunend niet-technisch personeel wordt een pensioenuitstroom van circa $3 \%$ verwacht, terwijl naar verwachting $2 \%$ van de ondersteunende technici de arbeidsmarkt zal verlaten. De verwachte uitstroom van technisch opgeleide verkopers is opvallend laag. De bedrijven verwachten dat nog geen I\% van deze werknemers in de komende 5 jaar met pensioen zal gaan.

\section{Vergrijzing in de Metalektro in de komende jaren}

Ook uit cijfers van het Metalektro-pensioenfonds PME blijkt dat de vergrijzing van het personeelsbestand de komende jaren een grote rol zal gaan spelen. Figuur 7.5 
geeft, voor mannen en vrouwen afzonderlijk, een overzicht van de leeftijdsopbouw van het personeel in 2006.

\section{Figuur 7.5}

Leeftijdsopbouw van het personeel in de Metalektro, 2006

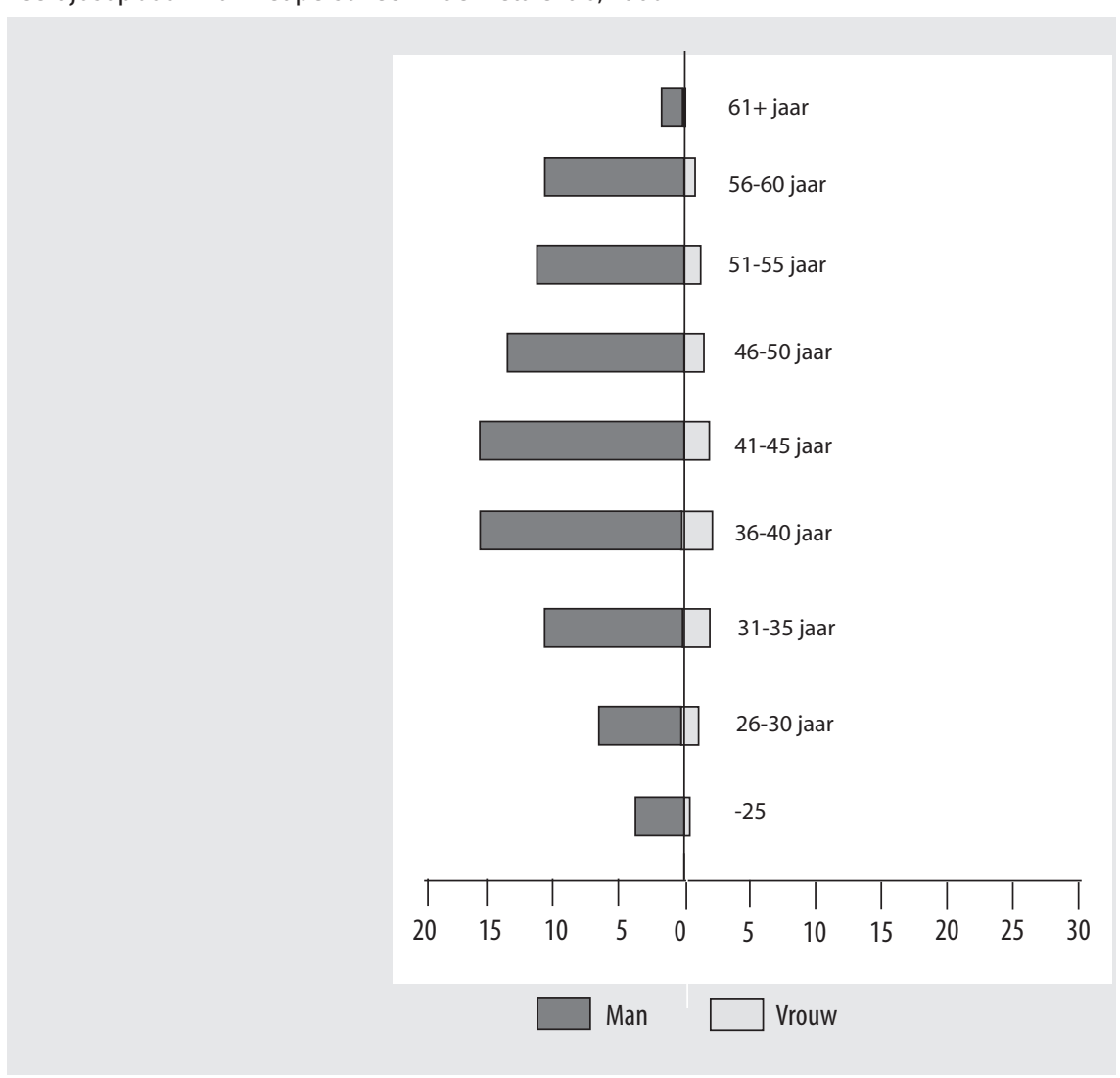

Bron: Pensioenfonds Metalektro (PME)

De figuur laat duidelijk zien dat het personeelsbestand in de Metalektro sterk vergrijsd is. Slechts circa $4 \%$ van het personeelsbestand is 25 jaar of jonger. Ruim $40 \%$ van het personeel is ouder dan 45 jaar. Het personeel dat nu 56 jaar of ouder is zal de komende Io jaar zeker de arbeidsmarkt verlaten. Dit betekent dat ruim $13 \%$ van het huidige personeel in de komende io jaar met pensioen zal gaan. Figuur 7.5 laat ook zien dat maar liefst $27 \%$ van het personeelsbestand tussen 46 en 55 jaar oud is. Een gedeelte van deze mensen zal ook de komende io jaar met pensioen gaan en diegenen die de komende jaren nog wel blijven werken zullen over Io jaar vlak bij hun pensioenleeftijd zitten en grotendeels in de jaren daarna uitstromen. De figuur laat ook zien dat de vergrijzing van vrouwelijke werknemers iets minder ver is voortgeschreden dan de vergrijzing van mannelijke werknemers. Het werkgelegenheidsaandeel van vrouwe- 
lijke werknemers onder de 40 jaar is, relatief genomen, groter dan het aandeel van mannelijke werknemers van 40 jaar of jonger.

\section{Vervangingsproblemen door vergrijzing}

De uitstroom van oudere werknemers kan de komende jaren in sommige Metalektrobedrijven tot problemen gaan leiden wanneer er personeel vervangen moet worden. Andere bedrijven zullen hun uitstromende personeel niet vervangen, omdat er minder behoefte is aan personeel. Ook zullen er bedrijven zijn die laagopgeleide werknemers die met pensioen gaan vervangen door middelbaar of hoger opgeleiden.

Figuur 7.6

Verwachte vervangingsproblemen door pensioen naar beroepscategorie, 2005 (\% bedrijven)

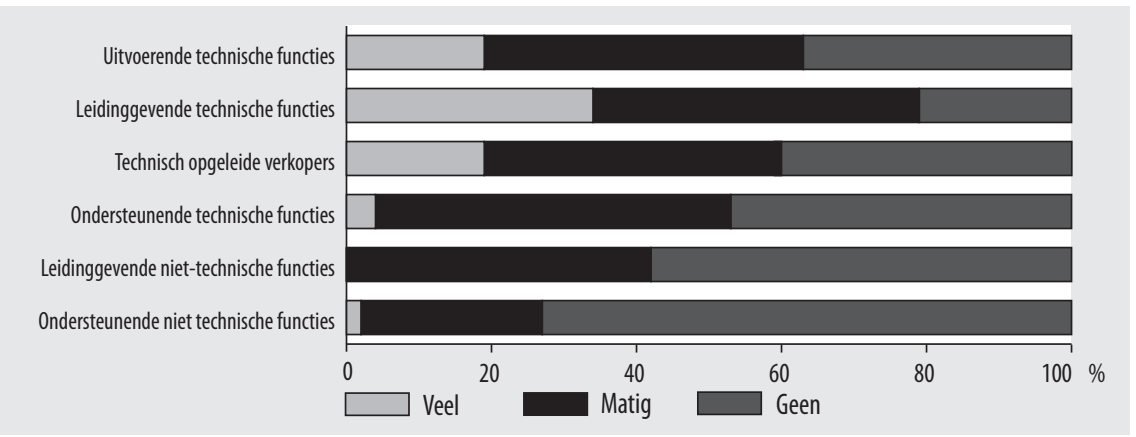

Bron: ROA/Werkgeverspanel Metalektro 2005

Figuur 7.6 geeft per functiecategorie een overzicht van de verwachte vervangingsproblemen door pensioen. Het blijkt dat de mate waarin bedrijven vervangingsproblemen verwachten sterk afhangt van de functiecategorie. De bedrijven verwachten de meeste problemen met de vervanging van technisch personeel. De problemen zijn het grootst bij het leidinggevend technisch personeel. Ruim 30\% van de bedrijven verwacht de komende tijd veel problemen bij het vervangen van leidinggevende technici die met pensioen gaan. Ook bij uitvoerende technici en technisch opgeleide verkopers worden er behoorlijke vervangingsproblemen verwacht: $20 \%$ van de bedrijven verwacht bij het vervangen van deze werknemers grote problemen, terwijl $40 \%$ aangeeft dat ze enige vervangingsproblemen verwachten. Bij de vervanging van ondersteunende technici verwacht slechts $4 \%$ van de bedrijven veel problemen, maar de helft van de bedrijven verwacht wel enige problemen. Voor de ondersteunende en leidinggevende niet-technische functies zijn de problemen het minst groot. Geen enkel bedrijf verwacht veel problemen bij het vervangen van de niet-technisch leidinggevenden die de komende jaren met pensioen gaan. Ook het vervangen van niet-technische ondersteuners zal naar verwachting zonder al te veel problemen gaan: Meer dan $70 \%$ van de bedrijven verwacht hierbij geen problemen te ondervinden. 
Om meer inzicht te krijgen in de toekomstige problemen bij het vervangen van vertrekkend personeel is de bedrijven ook gevraagd om voor een aantal specifieke technische functies aan te geven in hoeverre ze vervangingsproblemen verwachten. Uit figuur 7.7 blijkt dat circa één op de drie metalektrobedrijven de komende jaren veel problemen verwacht bij het vervangen van werknemers in de machinaal verspanende en plaatverwerkende beroepen. Ruim $20 \%$ van de bedrijven verwacht veel problemen bij het vervangen van het personeel in de bankwerkberoepen. Daarnaast verwacht bijna de helft van de bedrijven voor deze functies enige vervangingsproblemen te zullen ondervinden. Ook voor de montageberoepen en de overige geschoolde technici geschoold personeel verwacht een aanzienlijk deel van de bedrijven enige vervangingsproblemen door pensioen van vaklieden. Daarentegen verwachten veel bedrijven geen grote vervangingsproblemen voor het laag en ongeschoolde personeel, personeel in de pijpverwerkende beroepen en elektromonteurs.

\section{Figuur 7.7}

Verwachte vervangingsproblemen door pensioen van vaklieden, 2005 (\% bedrijven)



Bron: ROA/Werkgeverspanel Metalektro 2005

\section{Maatregelen om met toekomstige vervangingsproblemen om te gaan}

Hoe gaan de metalektrobedrijven om met de verwachte vervangingsproblemen die als gevolg van het met pensioen gaan van het technisch personeel zullen ontstaan? Figuur 7.8 geeft een overzicht van de maatregelen die bedrijven nemen om de problemen te beperken. Het blijkt dat veel bedrijven, die vervangingsproblemen verwachten, hier op de een of andere wijze op anticiperen. Zo kiest ruim $70 \%$ van de bedrijven ervoor om vervangingsproblemen te voorkomen door nieuwe werknemers aan te nemen die in het bedrijf zelf worden opgeleid. Daarnaast speelt het bevorderen van de inzetbaarheid van het personeel dat bedrijven in dienst hebben een belangrijke rol: $56 \%$ van de bedrijven probeert de vervangingsproblemen voor te zijn door het technisch personeel breder inzetbaar te maken door middel van taakroulatie. 


\section{Figuur 7.8}

Maatregelen om vervangingsproblemen voor technisch personeel te beperken, 2005 (\% bedrijven)

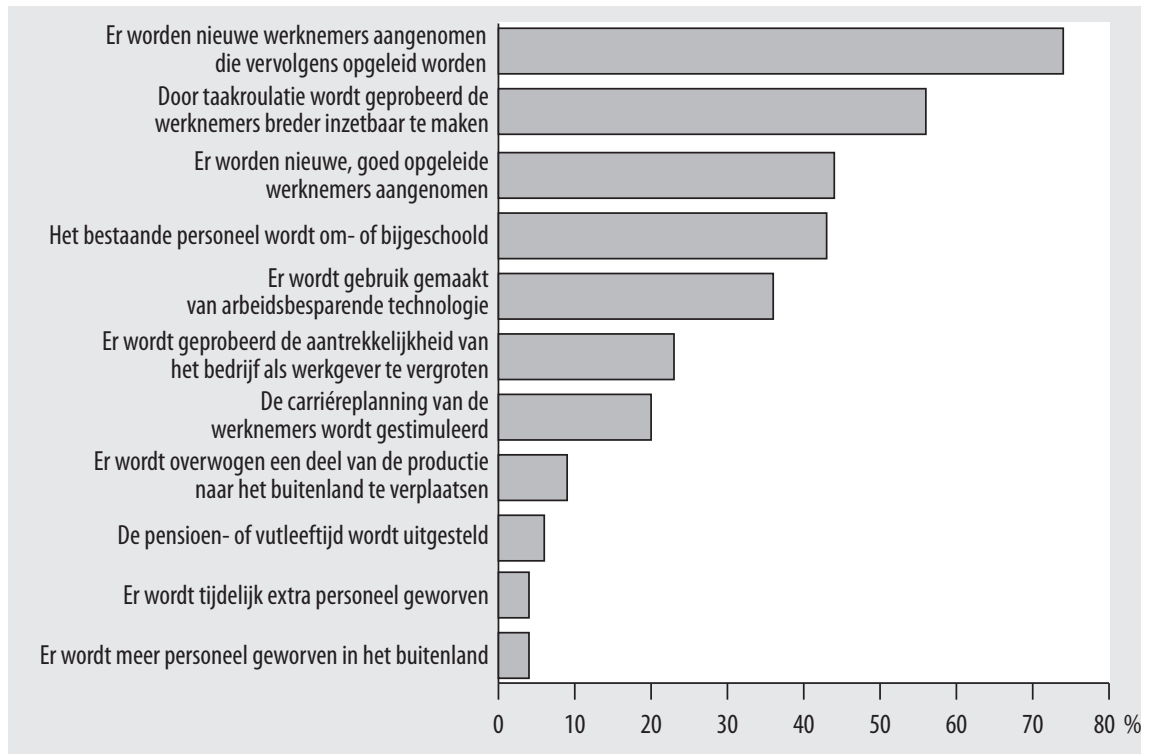

Bron: ROA/Werkgeverspanel Metalektro 2005

Bijna de helft van de bedrijven probeert de toekomstige vervangingsproblemen voor te zijn door nu al nieuw en goed opgeleid technisch personeel aan te nemen, of door het huidige personeel om- of bij te scholen. Veel bedrijven kiezen er dus voor om de benodigde kennis en vaardigheden op de arbeidsmarkt in te kopen, terwijl nog meer bedrijven er juist voor kiezen om het vakmanschap in eigen huis te ontwikkelen.

Circa een derde van de bedrijven verwacht de vervangingsproblemen die zullen ontstaan doordat oudere werknemers de komende jaren het bedrijf zullen verlaten op te vangen door arbeidsbesparende technologie in te zetten. Daarnaast zijn er bedrijven die hun wervingsbeleid willen gaan aanpassen. Zo probeert ruim $20 \%$ van de bedrijven als werkgever aantrekkelijker te worden voor potentiële werknemers. Eén op de vijf bedrijven probeert de vervangingsproblemen te beperken door de carrièreplanning van het technisch personeel te stimuleren. Op deze wijze wordt de interne doorstroom in het bedrijf vergroot en zal men meer personeel kunnen werven voor beginnersbanen, waarvoor geen werkervaring vereist is.

Enkele bedrijven nemen andere maatregelen om de problemen bij de vervanging van het technisch personeel te voorkomen. Zo zal $9 \%$ van de bedrijven een deel van de productie naar het buitenland verplaatsen. Andere bedrijven zullen vervangingsproblemen proberen te voorkomen door de pensioenleeftijd te verhogen (6\%), tijdelijk 
extra personeel aan te trekken (4\%), of personeel in het buitenland te gaan werven $(4 \%)$.

\subsection{Speerpunten voor toekomstig personeelsbeleid}

Als gevolg van tal van technologische en organisatorische innovaties verandert de inhoud van de functies van het technisch personeel. Dit stelt ook eisen aan het te voeren personeelsbeleid. Het voeren van een goed personeelsbeleid is essentieel, omdat het kunnen beschikken over goed opgeleid en gemotiveerd personeel een belangrijke voorwaarde is om goed op de verwachte dynamiek in te kunnen spelen. Maar wat doen de bedrijven in de Metalektro op dit punt concreet? Om hier enig inzicht in te krijgen is aan de bedrijven in het werkgeverspanel Metalektro de vraag voorgelegd op welke speerpunten ze hun personeelsbeleid de komende vijf jaar gaan richten. Figuur 7.9 geeft daarvan een overzicht.

\section{Figuur 7.9}

Speerpunten waarop bedrijven de komende vijf jaar beleid gaan voeren, 2005 (\% bedrijven)

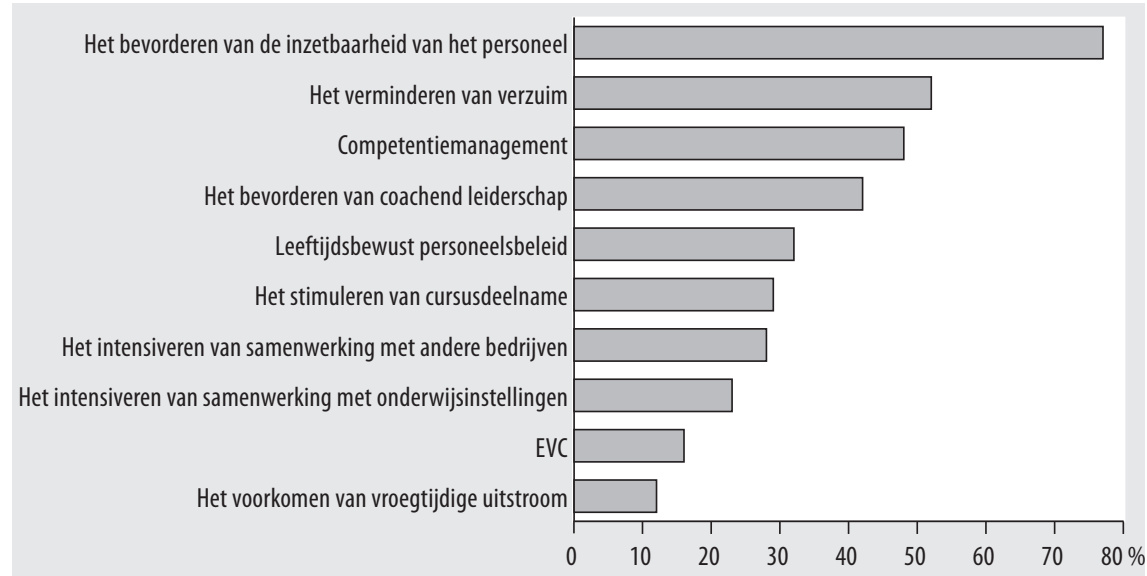

Bron: ROA/Werkgeverspanel Metalektro 2005

Het bevorderen van de inzetbaarheid van het technisch personeel is het belangrijkste speerpunt in het personeelsbeleid voor de komende jaren. Maar liefst $77 \%$ van de bedrijven in de Metalektro geeft aan dit als een belangrijk speerpunt te zien. Interviews met metalektrobedrijven bevestigen dit beeld. Een personeelsmanager: "We sturen steeds meer aan op een maximalisering van de flexibele inzetbaarheid. Dat doen we door mensen op te leiden en door mensen ook daadwerkelijk flexibel in te zetten". In een ander bedrijf wordt de flexibele inzetbaarheid van het personeel zo belangrijk gevonden dat het een uitgangspunt is geworden in de bedrijfsstrategie: "Naast commitment is flexibiliteit een belangrijke peiler in ons HRM-beleid geworden". 
Een tweede belangrijk speerpunt is het verminderen van het verzuim. Ruim de helft van de bedrijven geeft aan dat ze hieraan de komende vijf jaar extra aandacht wil besteden. Ook competentiemanagement wordt in bijna de helft van de bedrijven gezien als een belangrijk speerpunt. Daarnaast zullen veel bedrijven extra aandacht besteden aan de rol van leidinggevenden. Ruim $40 \%$ van de bedrijven geeft aan het coachend leidinggeven te gaan stimuleren. Leeftijdsbewust personeelsbeleid en het stimuleren van cursusdeelname is voor circa een derde van de bedrijven de komende vijf jaar een belangrijk speerpunt. Enkele bedrijven zien het intensiveren van de samenwerking met andere bedrijven of onderwijsinstellingen, EVC of het voorkomen van vroegtijdige uitstroom als belangrijk speerpunt voor de komende vijf jaar. Een bedrijf uit de metaalproductensector benadrukt de noodzaak van betere contacten met het onderwijsveld: "We hebben nu weliswaar contacten op bestuursniveau, maar veel minder met de opleidingen zelf. Daar moeten we in de toekomst veel meer aandacht aan gaan besteden. Maar de scholen moeten wel wat beter gaan meewerken. Een tijd geleden organiseerden we een open dag voor MBO docenten. Die dag moest worden afgeblazen doordat er te weinig interesse voor was".

Een opmerkelijk verschil met voorgaande jaren is dat in 2005 minder bedrijven aangeven dat ze EVC als een speerpunt voor hun toekomstig personeelsbeleid zien. In hoofdstuk 6 bleek dat het aantal bedrijven dat met EVC werkt in 2005 verdubbeld is. De daling van het aantal bedrijven dat EVC als speerpunt voor toekomstig beleid ziet zal daarom grotendeels verklaard kunnen worden door het feit dat een aanzienlijk deel van de bedrijven die EVC belangrijk vinden dit inmiddels al hebben ingevoerd.

Een high-tech bedrijf verwacht een ontwikkeling in het personeelsbeleid die niet in figuur 7.9 genoemd wordt. Volgens dat bedrijf krijgt het personeelsbeleid een heel andere invulling dan nu: "We gaan onszelf steeds meer richten op de menselijke kant van de zaak. Het gaat niet langer alleen om het aanbieden van instrumenten, maar vooral ook om het faciliteren van de bedrijfscommunicatie die als doel heeft allerlei veranderingsprocessen te ondersteunen. Die nieuwe rol houdt niet in dat onze HRM afdeling verantwoordelijkheden van het lijnmanagement gaat overnemen. Het gaat juist om het ontdekken en exploiteren van nieuwe verantwoordelijkheden. Daar zullen we als HRM-afdeling ook steeds meer op worden afgerekend”.

Kunnen de metalektrobedrijven de speerpunten in hun personeelsbeleid ook gemakkelijk realiseren? Uit het werkgeverspanel Metalektro blijkt dat maar liefst de helft van de bedrijven op dit punt bepaalde belemmeringen verwacht. Bij welke speerpunten verwachten deze bedrijven dan belemmeringen?

Figuur 7.Io laat zien dat 34\% van de metalektrobedrijven bepaalde belemmeringen verwacht bij het verminderen van het verzuim, terwijl $29 \%$ van de bedrijven belemmeringen verwacht bij het voeren van een leeftijdsbewust personeelsbeleid. $32 \%$ van de bedrijven verwacht belemmeringen bij het bevorderen van de inzetbaarheid van het personeel. Het gaat dan bijvoorbeeld om tekortschietende kennis en vaardig- 
heden, onvoldoende leervermogen of een te weinig flexibele houding. Een uitspraak van een personeelsfunctionaris illustreert dat: "Een groot deel van de flexibele inzetbaarheid moet wel vanuit de mensen zelf komen. Het is een soort ruilrelatie. Wij bieden de mensen mogelijkheden wanneer ze bereid zijn zich flexibel op te stellen en prestatiegericht zijn".

\section{Figuur 7.10}

Belemmeringen bij het realiseren van speerpunten in het personeelsbeleid in de komende vijf jaar, 2005 (\% bedrijven met bepaalde speerpunten)

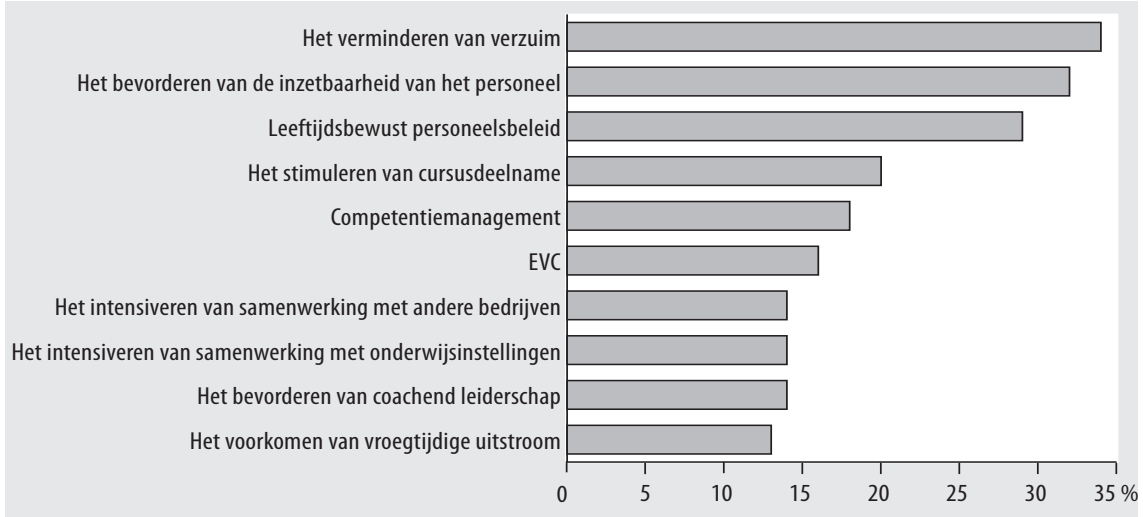

Bron: ROA/Werkgeverspanel Metalektro 2005

Een op de vijf bedrijven verwacht belemmeringen bij het stimuleren van de cursusparticipatie. Enkele bedrijven gaven ook aan waarom ze denken dat het moeilijk zal worden om het personeel ertoe aan te zetten om meer cursussen te gaan volgen. Het blijkt dat die bedrijven vinden dat het personeel niet genoeg gemotiveerd is of dat het opleidingsniveau ontoereikend is. Ook geven sommige bedrijven aan dat het plannen van cursussen en trainingen problemen gaat opleveren.

I8\% van de bedrijven verwacht belemmeringen bij het invoeren van competentiemanagement. Ook ervaren sommige bedrijven belemmeringen bij de invoering van EVC (I6\% van de bedrijven), het intensiveren van de samenwerking met andere bedrijven of opleidingsinstellingen (I4\%), het bevorderen van coachend leiderschap (I4\%) en het voorkomen van vroegtijdige uitstroom. Het voorkomen van vroegtijdige uitstroom is volgens enkele bedrijven moeilijk, omdat het een lastig te beïnvloeden factor is en omdat er nog veel werknemers zijn die nog steeds min of meer verwachten relatief vroeg uit te kunnen treden.

\subsection{Opleiden in de toekomst}

Hoe zullen de bedrijven met hun opleidingsbeleid reageren op de ontwikkelingen die de komende jaren plaats zullen vinden? Om hier enig inzicht in te krijgen is aan 
de bedrijven gevraagd om aan te geven aan welke competenties er bij cursussen en trainingen voor het technisch personeel in de toekomst meer aandacht zou moeten worden besteed. Om na te kunnen gaan in hoeverre de meningen van de bedrijven op dit punt veranderen worden in figuur 7.II zowel de cijfers van 2004 als 2005 gepresenteerd.

\section{Figuur 7.11}

Competenties waaraan in de toekomst volgens de bedrijven bij cursussen en trainingen van het technisch personeel meer aandacht moet worden besteed, 2004-2005 (\% bedrijven)



Bron: ROA/Werkgeverspanel Metalektro 2004-2005

De figuur laat zien dat de metalektrobedrijven erg veel waarde blijven hechten aan een goede vakkennis van hun technisch personeel. Ruim $60 \%$ van de bedrijven vindt dat hier in de toekomst nog meer aandacht aan zou moeten worden besteed. Ook vindt 
de helft van de bedrijven dat er meer aandacht moet komen voor cursussen en trainingen die gericht zijn op het verbeteren van de communicatieve vaardigheden en het probleemoplossend vermogen van hun personeel. In hoofdstuk 5 bleek dat momenteel slechts bij minder dan een kwart van de bedrijven het technisch personeel dergelijke cursussen volgt. Ook de andere metalektrobedrijven doen er wellicht goed aan om hun personeel cursussen gericht op het verbeteren van de communicatieve vaardigheden en het probleemoplossend vermogen te laten volgen. Dit hoeft echter niet te betekenen dat werknemers cursussen zouden moeten gaan volgen waarin enkel het verbeteren van de communicatieve vaardigheden of het probleemoplossend vermogen centraal staan. Er zou ook meer aandacht besteed kunnen worden aan communicatieve vaardigheden en probleemoplossend vermogen door deze competenties op een effectieve wijze te integreren in andere (bijvoorbeeld vaktechnische) cursussen, of via coachingstrajecten de ontwikkeling van deze competenties te stimuleren. Het is opvallend dat sommige bedrijven twijfelen of probleemoplossend vermogen wel goed ontwikkeld kan worden wanneer alleen het bedrijf inspanningen levert: "Goed probleemoplossend bezig zijn, dat moet vooral vanuit de werknemers zelf komen. Daar schort het bij ons nogal eens aan”.

Wanneer we kijken naar de verschillen tussen de jaren 2004 en 2005, dan blijkt dat probleemoplossend vermogen en communicatieve vaardigheden door steeds meer bedrijven gezien worden als de sleutelcompetenties waarop hun toekomstig opleidingsbeleid zich zal moeten richten. Het aantal bedrijven dat aangeeft dat er meer geschoold moet gaan worden om de communicatieve vaardigheden van het technisch personeel te vergroten is zelfs fors gestegen van $39 \%$ in 2004 naar $51 \%$ in 2005 . Interviews met metalektrobedrijven bevestigen deze trend. Een bedrijf uit de metaalproductensector: "We gaan steeds meer de nadruk leggen op soft skills. Teamwork, het kunnen aansturen van mensen en de communicatieskills zullen voor onze productieprocessen namelijk steeds belangrijker worden”. Een bedrijf uit de regio Zuid gaat zich zelfs uitsluitend richten op het verbeteren van de communicatieve vaardigheden: "Goed kunnen communiceren wordt steeds meer een sleutelvaardigheid. Maar we gaan onze mensen zeker niet alleen formeel opleiden om beter te leren communiceren. Communicatieve vaardigheden leer je immers ook gewoon tijdens het werk, door samen te werken met anderen en door flexibele inzet".

Het aantal bedrijven dat aangeeft dat er vooral meer aandacht besteed moet worden aan vaktechnische vaardigheden is daarentegen wat afgenomen. Het is opmerkelijk dat ook het aantal bedrijven dat vindt dat er in het toekomstig opleidingsbeleid meer aandacht moet worden besteed aan het bevorderen van de flexibiliteit van het personeel tussen 2004 en 2005 met IO\% is afgenomen. Zoals we al eerder zagen betekent dat echter niet dat bedrijven flexibiliteit minder belangrijk zijn gaan vinden. Het duidt er eerder op dat steeds meer bedrijven zich realiseren dat flexibiliteit niet noodzakelijk via formele cursussen of trainingen geleerd hoeft te worden, maar eerder door het stimuleren van 'learning by doing' door middel van functieroulatie, of door mensen op een andere manier er toe aan te zetten taken te verrichten die niet tot hun 
eigen functie behoren. Toch zijn er ook bedrijven die ook in hun formele opleidingen meer aandacht willen gaan besteden aan het stimuleren van de flexibiliteit van het personeel. Een HRM-manager: "We moeten in onze opleidingen veel meer aandacht gaan besteden aan de kwalitatieve flexibiliteit. Veel techneuten zijn te behoudend en houden niet van verandering en dat moet veranderen. De tijd dat we met inflexibele mensen konden werken is duidelijk voorbij. Dat kan echt niet meer".

Enkele competenties waaraan volgens een aantal bedrijven in het toekomstige opleidingsbeleid meer aandacht zou moeten worden besteed worden in 2005 wel steeds vaker genoemd. Het gaat dan om procesgericht werken, werken in teamverband en veilig gedrag. De stijging van het aantal bedrijven dat meer aandacht wil besteden aan opleidingen waardoor hun personeel meer procesgericht kan werken is aanzienlijk: van $24 \%$ in 2004 tot $43 \%$ in 2005 . Waarschijnlijk leiden de veranderingen in de productieprocessen er toe dat procesgericht en in teamverband werken steeds belangrijker worden voor het succes van veel metalektrobedrijven. Sommige bedrijven leggen echter weer andere accenten. Een bedrijf in de metaalproductensector denkt dat er in de toekomst steeds maar aandacht zal komen voor cursussen veilig gedrag: "Daarmee realiseren we twee dingen tegelijk. Onze mensen zijn beter toegerust om hun werk goed uit te voeren en we verminderen het ziekteverzuim". 


\section{Agenda voor de toekomst}

"Bij ons staan er drie zaken op de agenda van de toekomst. We willen ons groeiscenario tot $20 I 0$ realiseren, het personeel verder ontwikkelen en onze mensen het idee blijven geven dat ze bij ons de vrijheid hebben om zich verder te ontwikkelen".

"We moeten goed blijven presteren op de markt waarop we actief zijn door vooruit te lopen qua technologie en innovatie".

"Het is niet ondenkbaar dat we in de toekomst meer activiteiten gaan uitbesteden aan vestigingen of andere bedrijven in Oost-Europa of Azie".

"We hebben drie uitdagingen die we willen realiseren: het aanboren van nieuwe markten en nieuwe klanten, het goede personeel aan ons binden en het nog meer bevorderen van de inzetbaarheid".

"We moeten het hoofd boven water zien te houden in een omgeving met sterke concurrentie vanuit Oost-Europa en Azië. Daarom moeten we focussen op lage kosten en hoge productiviteit".

De bedrijven in de Metalektro hebben veelal duidelijk voor ogen met welke ontwikkelingen ze de komende jaren geconfronteerd worden en wat ze moeten doen om hun concurrerend vermogen te vergroten. Naast de technische innovatiegerichtheid speelt het arbeidsmarkten personeelsbeleid hierbij een grote rol. Op dit HRM-vlak blijkt er echter nog een aantal lacunes te bestaan, die het realiseren van de ambities van de bedrijven in de weg staan. Daarom is er in de Arbeidsmarktmonitor Metalektro 2004 een 'Agenda voor de Toekomst' opgesteld, waarin zeven speerpunten zijn opgenomen die cruciaal zijn voor het toekomstige HRM-beleid dat er in de Metalektro gevoerd zal moeten worden. In dit hoofdstuk wordt eerst de vraag gesteld in welke mate de metalektrosector vooruitgang boekt bij het realiseren van de ambities die in de Agenda van de Toekomst geformuleerd zijn. Daarna kijken we of de resultaten van de Arbeidsmarktmonitor Metalektro 2005 aanleiding geven om de Agenda van de Toekomst bij te stellen: Is er een noodzaak voor nieuwe prioriteiten in het arbeidsmarkt-en personeelsbeleid van de metalektrobedrijven in de komende jaren? 


\subsection{De Agenda voor de Toekomst}

De ontwikkelingen op de afzetmarkten en arbeidsmarkten waarmee de metalektrobedrijven te maken hebben, het personeelsbeleid dat ze voeren en de competenties die ze in de komende jaren nodig hebben om hun marktpositie te versterken heeft in de Arbeidsmarktmonitor Metalektro 2004 geleid tot het formuleren van een Agenda voor de Toekomst. Deze agenda had als motto: competent en breder inzetbaar. De Agenda voor de Toekomst omvat de volgende cruciale bestanddelen:

1. De POFI-Agenda, gericht op het versterken van het competentieniveau van het personeel, met betrekking tot de vier competenties waaraan bedrijven in de toekomst vooral behoefte hebben:

a. probleemoplossend vermogen;

b. omgaan met veranderingen;

c. flexibiliteit;

d. initiatief.

2. Opleidingen en trainingen moeten beter gaan aansluiten op de competenties die bedrijven (in de toekomst) nodig hebben.

3. Naast formele cursussen en trainingen zou er meer aandacht moeten komen voor informele manieren van kennisverwerving, zoals coaching, en 'learning by doing'. Wanneer deze informele scholing gecombineerd wordt met formele cursussen ontstaat er in de bedrijven een 'leerrijke werkomgeving' waarin leren en werken een strategisch geheel vormen.

4. Het opscholen van de instroom van schoolverlaters naar het voor een optimaal functioneren vereiste competentieniveau.

5. Het aandacht blijven houden voor laagopgeleide en oudere werknemers. Wanneer deze groepen niet kunnen worden bijgeschoold tot een hoger niveau, moet er zorg voor gedragen worden dat ze voldoende breed inzetbaar zijn en wel beschikken over de competenties die de bedrijven op de lagere functieniveaus nodig hebben.

6. Het vergroten van de doorstroom van het personeel om de brede inzetbaarheid van het personeel te vergroten. Doorstroom van ouder personeel naar minder belastende functies kan er toe bijdragen dat oudere werknemers langer productief aan het werk kunnen blijven.

7. Verdere uitbouw van HRM-instrumenten die de brede inzetbaarheid bevorderen: loopbaan/carrière planning, functieroulatie, EVC, coachend leidinggeven, competentiemanagement en uitwisseling van werknemers.

\subsection{Is de Metalektro op de goede weg?}

In hoeverre is de Nederlandse metalektrosector op de goede weg om de doelstellingen van de Agenda van de Toekomst te realiseren? Voor ieder speerpunt gaan we in op twee vragen: 
1. In welke mate zijn metalektrobedrijven zich bewust zijn van het belang van het speerpunt?

2. Wordt er concrete vooruitgang geboekt?

\section{De POFI-agenda}

Bij de POFI-agenda, waarin het versterken van de vier sleutelcompetenties waaraan bedrijven in de toekomst vooral behoefte hebben centraal staat, is er sprake van enige vooruitgang. In steeds meer bedrijven volgt het personeel cursussen of trainingen gericht op het verbeteren van hun probleemoplossend vermogen. De cursusparticipatie gericht op het versterken van de andere drie POFI-competenties, omgaan met veranderingen, flexibiliteit en initiatief is daarentegen hetzelfde gebleven als in 2004 . Veel bedrijven zijn zich echter terdege bewust van het belang van de ontwikkeling van de POFI-competenties, maar realiseren zich dat deze competenties voor een belangrijk deel ook op informele wijze kunnen worden aangeleerd. De verantwoordelijkheid voor deze competentie-ontwikkeling komt overigens ook meer bij de werknemers zelf te liggen. Een opvallende ontwikkeling is dat in steeds meer bedrijven het personeel cursussen of trainingen in de eigen tijd volgt. Daarnaast is er duidelijk sprake van een individualisering van het opleidingsbeleid: Het aantal bedrijven met persoonlijke ontwikkelingsplannen (POP's) stijgt, terwijl het bedrijfsopleidingsplan (BOP) in populariteit afneemt. Ten slotte zijn er aanwijzingen dat de bedrijven hun opleidingsinspanningen verbreden. De metalektrobedrijven betrekken meer werknemers bij opleidingen en trainingen dan in voorgaande jaren.

\section{Betere aansluiting tussen het huidige opleidingsbeleid en de in de toekomst benodigde competenties}

De bedrijven in de Metalektro hebben de komende jaren naast een goede vakkennis vooral behoefte aan de POFI-competenties en goede communicatieve vaardigheden. Hoewel het aantal bedrijven dat vindt dat er de komende jaren meer aandacht besteed moet worden aan de vaktechnische vaardigheden van het personeel licht gedaald is, blijft goede vakkennis van groot belang. Dit is goed terug te zien in het huidige opleidingsbeleid: In veel bedrijven volgt het personeel cursussen en trainingen die gericht zijn op het versterken van de vaktechnische competenties. De aansluiting tussen de in de toekomst benodigde POFI-competenties en communicatieve vaardigheden en het huidige formele opleidingsbeleid is daarentegen veel minder goed. Zo volgt het personeel slechts in een kwart van de bedrijven cursussen of trainingen die gericht zijn op het verbeteren van het probleemoplossend vermogen of de communicatieve vaardigheden, terwijl meer dan de helft van de bedrijven aangeeft dat er aan deze competenties in de toekomst meer aandacht moet worden besteed. Ook flexibiliteit en het kunnen omgaan met veranderingen, twee competenties waaraan volgens een kwart van de bedrijven in de toekomst meer aandacht besteed moet worden, spelen in het huidige opleidingsbeleid nog maar een zeer beperkte rol. Dit betekent echter niet, zoals ook al eerder gesteld werd, dat er in de bedrijven voor deze competenties hele- 
maal geen aandacht is. Competenties kunnen immers ook door 'learning by doing' of op andere informele manieren worden aangeleerd. Desondanks zouden bedrijven er wellicht goed aan doen om ook in het formele opleidingsbeleid meer aandacht te gaan besteden aan POFI-competenties en communicatieve vaardigheden. Dat heeft als groot voordeel dat de prioriteiten in het opleidingsbeleid beter naar voren komen en dat de ontwikkeling van deze competenties beter aangestuurd kan worden. De aanbieders van cursussen en trainingen lijken hier op in te spelen door opleidingen te ontwikkelen die aansluiten bij de behoefte van de bedrijven: steeds minder bedrijven vinden dat het aanbod van cursussen en trainingen tekortschiet.

Meer informeel leren en learning by doing

In de Arbeidsmarktmonitor Metalektro 2004 kwam al duidelijk naar voren dat informeel leren en 'learning by doing' belangrijke manieren zijn om het personeel competenties te laten verwerven. Uit de interviews met bedrijven blijkt dat veel bedrijven het belang van informeel leren duidelijk inzien. Daarbij komt echter ook naar voren dat de interesse van werknemers een belangrijke factor is voor het succes van informele leertrajecten. Ook blijkt er in bepaalde bedrijven een belangrijke wisselwerking te bestaan tussen formeel en informeel leren. Daarbij geeft het volgen van een cursus of training werknemers vakk een impuls om zelf op informele manieren verder te leren. Dit geeft aan dat sommige bedrijven nu al bezig zijn met het creëren van een leerrijke werkomgeving, waarbij verschillende vormen van leren en het dagelijkse werk één geheel vormen. Deze ontwikkeling wordt versterkt door de grote toename van het aantal bedrijven waar sprake is van functieroulatie (zie hieronder).

\section{Opscholen van de instroom van schoolverlaters}

Doordat de bedrijven in de Metalektro de komende jaren geconfronteerd zullen worden met een aanzienlijke uitstroom van oudere werknemers die als gevolg van (pré-) pensionering de arbeidsmarkt zullen verlaten, is het van groot belang dat de bedrijven voldoende aandacht blijven houden voor het competentieniveau van instromende schoolverlaters. Dat kan op verschillende manieren. Bedrijven kunnen er door middel van het opbouwen van goede relaties met het onderwijsveld toe bijdragen dat de schoolverlaters over de juiste competenties beschikken. Veel bedrijven vinden echter nog steeds dat de voor hen relevante schoolverlaters die bij hen in dienst komen te weinig intellectuele bagage meenemen en dat de scholen vooral meer aandacht zouden moeten besteden aan vaktechnischevaardigheden, probleemoplossend vermogen en flexibiliteit.

Een andere manier om ervoor te zorgen dat schoolverlaters over het juiste competentieniveau beschikken is dat bedrijven zelf hun instromende schoolverlaters opscholen tot het gewenste niveau. In de praktijk blijkt er al heel wat aan deze intredescholing' gedaan te worden. Bedrijfsspecifieke vaktechnische vaardigheden en bepaalde gedragscompetenties worden veelal in de eerste tijd dat een schoolverlater in dienst is, bijgebracht. Daarnaast blijkt dat bijna de helft van de schoolverlaters van het VMBO die aan de slag gaan in de metaal en elektrotechnische sector hun oplei- 
dingsniveau verhogen door het volgen van een BBL-opleiding. Er zijn op dit punt overigens wel grote verschillen tussen grote en kleine bedrijven. Uit gesprekken bleek dat wanneer kleine bedrijven hun instromende personeel niveauverhogende scholingtrajecten aanbieden, dit vaak gaat om een beperkt aantal werknemers. Grote bedrijven lopen daarentegen vaak voorop wanneer het gaat om de opscholing van instromende schoolverlaters. Vanuit het besef dat er in de komende jaren door de krapte op de arbeidsmarkt voor schoolverlaters met bepaalde opleidingen verwingsproblemen zullen ontstaan, beginnen die bedrijven nu al aan grootschalige opscholingstrajecten.

\section{Aandacht voor laagopgeleide en oudere werknemers}

De aandacht voor laagopgeleide en oudere werknemers blijkt nog erg beperkt. Slechts $20 \%$ van de metalektrobedrijven houdt in hun HRM-beleid expliciet rekening met het oudere of laagopgeleide personeel. Dit terwijl circa $35 \%$ van de bedrijven aandacht besteedt aan jongere werknemers en leidinggevenden. Dat veel bedrijven weinig aandacht aan hun oudere personeel besteden staat in schril contrast met de vergrijzing van het personeelsbestand in de Metalektro en het opschuiven van de leeftijd waarop werknemers met pensioen kunnen gaan. Vanwege de geringe aandacht voor laagopgeleide werknemers in het HRM-beleid kan de upgrading van de functie-eisen in de toekomst leiden tot competentietekorten.

Hoewel sommige bedrijven aangaven dat de aandacht voor oudere werknemers de laatste tijd wel groeit, blijkt dat het HRM-beleid gericht op ouder personeel vooral een behoudsstrategie is, die de lagere productiviteit of inzetbaarheid van het oudere personeel als een gegeven beschouwt. Het uitgangspunt daarbij is niet het investeren in de kennis en vaardigheden van het oudere personeel, maar het bekijken hoe de oudere werknemers nog tot hun pensioen enigszins nuttig en plezierig aan het werk kunnen blijven.

\section{Doorstroom ten behoeve van brede inzetbaarheid}

De mobiliteit van technisch personeel naar andere technische functies is in 2005 in vergelijking met de jaren daarvoor flink toegenomen. Het blijkt hierbij vooral te gaan om horizontale mobiliteit. Ook de horizontale mobiliteit van technisch personeel naar niet-technische functies is in 2005 groter dan in voorgaande jaren. De grotere mobiliteit kan wellicht verklaard worden uit het feit dat steeds meer bedrijven de mobiliteit van hun personeel actief stimuleren. Ook blijkt dat nogal wat bedrijven hun personeel opleiden om zo de mobiliteit te vergroten. Ondanks deze positieve signalen vinden sommige bedrijven de mobiliteit van hun personeel nog veel te laag. Dat mobiliteit in nog lang niet alle bedrijven een sleutelrol speelt blijkt ook uit het feit dat er in bijna de helft van de metalektrobedrijven nog in het geheel geen sprake is van personeel dat doorstroomt. 
Op dit punt boeken de bedrijven in de Metalektro een duidelijke vooruitgang. In vergelijking met voorgaande jaren is het aantal bedrijven waar sprake is van functieroulatie zelfs spectaculair gestegen: van $25 \%$ in 2002 tot $65 \%$ in 2005 . Ook loopbaanplanning wint duidelijk aan populariteit. In 2002 was nog slechts $8 \%$ van de bedrijven actief betrokken bij de loopbaanplanning van hun personeel. In 2005 steeg dit tot $37 \%$ van de bedrijven. Ten slotte wordt ook EVC steeds meer toegepast en stijgt het gebruik van een competentie of vaardighedenmatrix. Dit wijst er op dat bedrijven er steeds meer aan gaan doen om een goed overzicht te krijgen van de competenties van hun werknemers. Het is duidelijk dat dit kan bijdragen aan een grotere inzetbaarheid van het personeel.

Een andere belangrijke ontwikkeling in het HRM-beleid in de Metalektro is dat steeds meer bedrijven functioneringsgesprekken (of beoordelingsgesprekken) houden met hun personeel. Ook houden steeds meer bedrijven geregeld werkoverleg met hun personeel. Dat wijst er op dat de metalektrobedrijven steeds meer zijn gaan inzien dat ook een goede communicatie met het personeel van groot belang is bij het vergroten van de inzetbaarheid.

\subsection{Nieuwe prioriteiten}

De resultaten van de Arbeidsmarktmonitor Metalektro 2005 bevestigen in grote mate de prioriteiten die in de Agenda van de Toekomst zijn verwoord. Toch zijn er ook enkele opvallende uitkomsten. Dit leidt tot enkele aanvullingen op of een verbreding van de Agenda van de Toekomst.

Het blijkt dat de POFI-competenties probleemoplossend vermogen en flexibiliteit niet alleen direct de productiviteit van het personeel vergroten, maar dat deze competenties ook in sterke mate bijdragen aan de inzetbaarheid van het personeel. Dit vergroot de noodzaak voor bedrijven om hun formele en informele opleidingsinspanningen te richten op het probleemoplossend vermogen en de flexibiliteit van hun personeel.

Bedrijven blijken ook steeds meer het belang in te zien van goede communicatieve vaardigheden en het procesgericht kunnen werken. De traditionele nadruk op vakkennis lijkt daarentegen wat minder belangrijk te worden. Procesgericht kunnen werken en communicatieve vaardigheden worden steeds meer sleutelcompetenties, die van groot belang zijn voor de productiviteit van het personeel. Daarom moeten ook deze competenties een prominentere plaats in het opleidingsbeleid krijgen.

Daarnaast blijkt dat nog meer bedrijven dan voorheen denken dat gedragsmatige competenties en klantgerichtheid de komende jaren steeds belangrijker worden in de functies van het technisch personeel. Aan gedragsmatige competenties wordt in de 
Agenda van de Toekomst aandacht besteed in de POFI-agenda. Klantvriendelijkheid is ook gerelateerd aan de POFI-competenties, maar klantvriendelijk werken vereist ook een bepaalde werkhouding. Daarom zou ook klantgerichtheid als specifiek ontwikkelterrein een aparte plaats moeten krijgen in de Agenda van de Toekomst.

Veel bedrijven ervaren momenteel een gebrek aan personeel met voldoende werkervaring. In de toekomst zal dat probleem nog dringender worden, wanneer veel ouder personeel vanwege (pré-)pensionering de arbeidsmarkt zal verlaten. Dit betekent dat steeds meer bedrijven er de komende jaren voor zullen moeten kiezen om personeel zonder werkervaring in dienst te nemen. De benodigde werkervaring zullen ze vervolgens zelf moeten ontwikkelen. Daarnaast kunnen de bedrijven er natuurlijk ook voor zorgen dat leerlingen en studenten de kans krijgen om tijdens de opleiding relevante werkervaring op te doen door het bieden van stageplaatsen, gerichte praktijkopdrachten of door op andere wijze de relaties met het onderwijsveld aan te gaan en deze op een pro-actieve manier in te vullen. 
